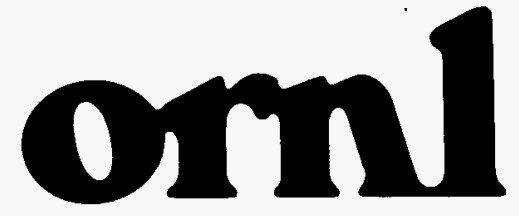

\section{OAK RIDGE \\ NATIONAL \\ LABORATORY}

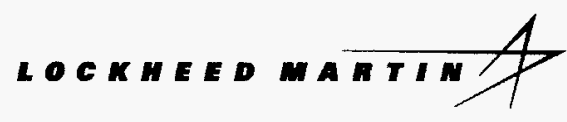

\section{Characterization and Inventory of
Contaminants in WAG 2 Floodplain \\ Characterization and Inventory of
Contaminants in WAG 2 Floodplain Soils of White Oak Creek}

C. J. Ford

J. E. Nyquist

S. T. Purucker

B. B. Burgoa

R. F. Winterfield

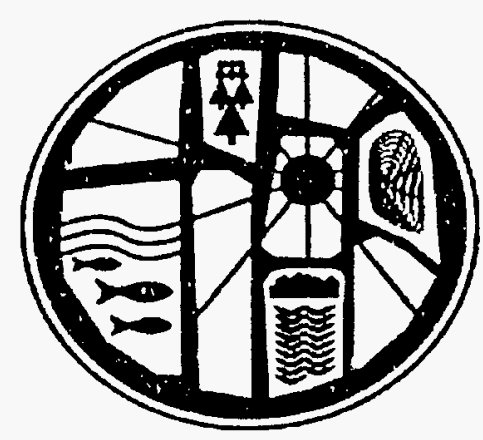

Environmental Sciences Division

Publication No. 4538

\section{MASTER}

\section{n}

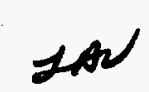

MANAGED AND OPERATED BY

LOCKHEED MARTIN ENERGY RESEARCH CORPORATION FOR THE UNTEO STATES

DEPARTMENT OF ENERGY

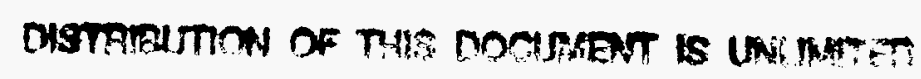




\section{REPRODUCTION QUALITY NOTICE}

This document is the best quality available. The copy furnished to DTIC contained pages that may have the following quality problems:

- Pages smaller or larger than normal.

- Pages with background color or light colored printing.

- Pages with small type or poor printing; and or

- Pages with continuous tone material or color photographs.

Due to various output media available these conditions may or may not cause poor legibility in the microfiche or hardcopy output you receive.

曰 If this block is checked, the copy furnished to DTIC contained pages with color printing, that when reproduced in Black and White, may change detail of the original copy. 
This report has been reproduced directly from the best available copy.

Available to DOE and DOE contractors from the Office of Scientific and Technical Information, P. O. Box 62, Oak Ridge. TN 37831: prices available from (423) 576-8401, FTS 626-8401.

Available to the public from the National Technical Information Service, U.S. Department of Commerce, 5285 Port Royal Road, Springfield. VA 22161 .

This report was prepared as an account of work sponsored by an agency of the United States Government. Neither the United States Government nor any agency thereof, nor any of their employees, makes any warranty, express or implied, or assumes any legal liability or responsibility for the accuracy, completeness, or usefulness of any information, apparatus, product, or process disclosed, or represents that its use would not infringe privately owned rights. Reference herein to any specific commercial product, process, or service by trade name. trademark, manufacturer, or otherwise, does not necessarily constitute or imply its endorsement, recommendation, or favoring by the United States Government or any agency thereof. The views and opinions of authors expressed herein do not necessarily state or reflect those of the United States Government of any agency thereof. 
Environmental Sciences Division

\title{
Characterization and Inventory of Contaminants in WAG 2 Floodplain Soils of White Oak Creek
}

\author{
C. J. Ford, J. E. Nyquist, S. T. Purucker, ${ }^{1}$ B. B. Burgoa, ${ }^{2}$ and R. F. Winterfield ${ }^{3}$
}

Environmental Sciences Division

Publication No. 4538

\begin{abstract}
'Health Sciences Research Division, ORNL.
${ }^{2} \mathrm{CDM}$ Federal Programs Corp., Oak Ridge, Tennessee.

${ }^{3}$ STEP Environmental, Inc., Oak Ridge, Tennessee.
\end{abstract}

Date Issued-January 1997

Prepared for

U.S. Department of Energy

Office of Environmental Restoration and Waste Management

under budget and reporting code EW 20

\author{
Prepared by the \\ Environmental Sciences Division \\ Oak Ridge National Laboratory \\ Oak Ridge, Tennessee 37831-6038 \\ managed by \\ LOCKHEED MARTIN ENERGY RESEARCH CORP. \\ for the \\ U.S. DEPARTMENT OF ENERGY \\ under contract DE-AC05-96OR22464
}




\section{CONTENTS}

Page

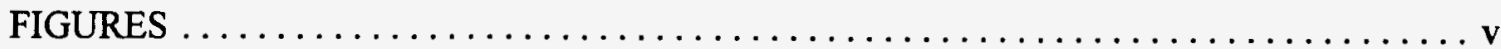

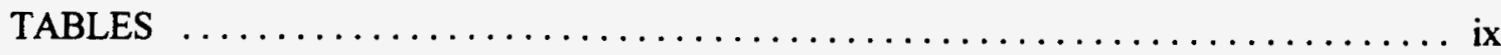

ABBREVIATIONS $\ldots \ldots \ldots \ldots \ldots \ldots \ldots \ldots \ldots \ldots \ldots \ldots \ldots \ldots \ldots \ldots \ldots \ldots \ldots \ldots \ldots$

EXECUTIVE SUMMARY $\ldots \ldots \ldots \ldots \ldots \ldots \ldots \ldots \ldots \ldots \ldots \ldots \ldots \ldots \ldots \ldots \ldots \ldots \ldots \ldots$

1. INTRODUCTION $\ldots \ldots \ldots \ldots \ldots \ldots \ldots \ldots \ldots \ldots \ldots \ldots \ldots \ldots \ldots \ldots \ldots \ldots$

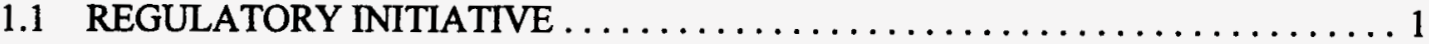

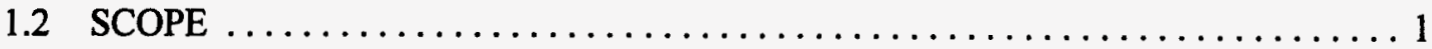

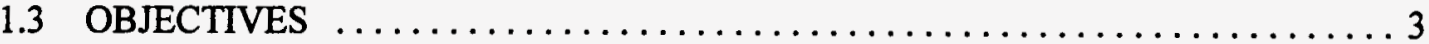

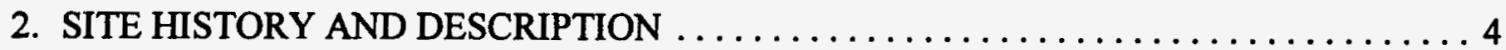

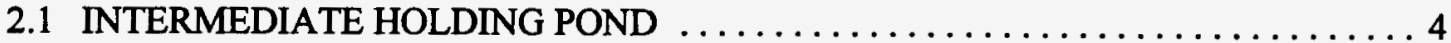

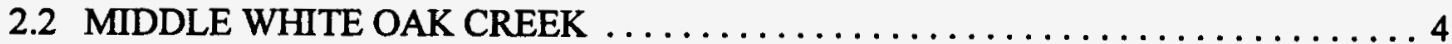

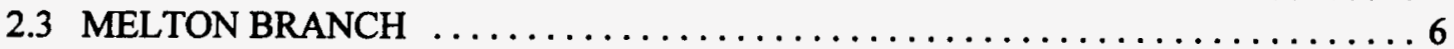

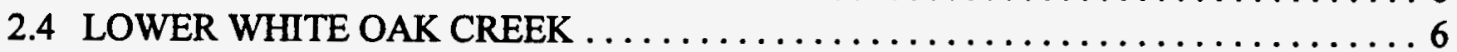

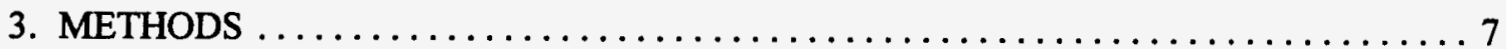

3.1 GAMMA WALKOVER SURVEY $\ldots \ldots \ldots \ldots \ldots \ldots \ldots \ldots \ldots \ldots \ldots$

3.2 SOIL AND SEDIMENT COLLECTION STRATEGY $\ldots \ldots \ldots \ldots \ldots \ldots \ldots \ldots$.

3.3 FIELD SAMPLING AND PROCESSING $\ldots \ldots \ldots \ldots \ldots \ldots \ldots \ldots \ldots \ldots \ldots$

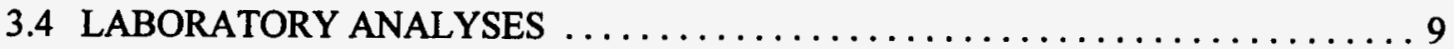

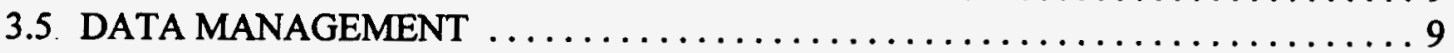

3.6 QUALITY ASSURANCE AND QUALITY CONTROL $\ldots \ldots \ldots \ldots \ldots \ldots \ldots \ldots \ldots$

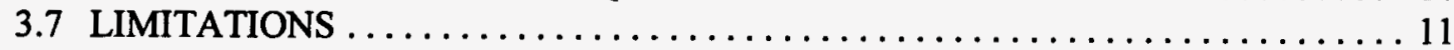

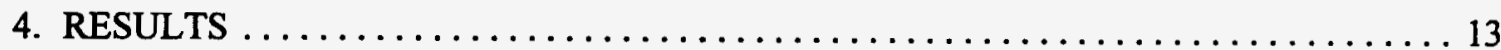

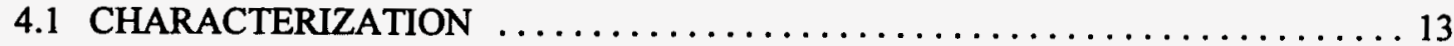

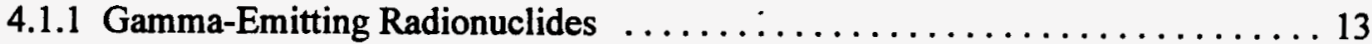

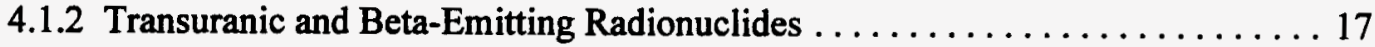

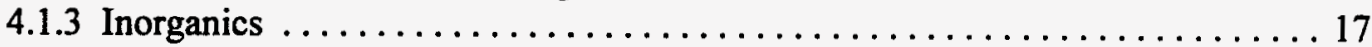

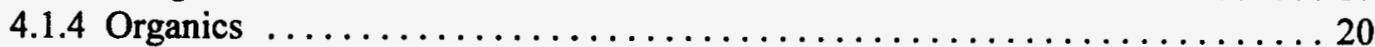

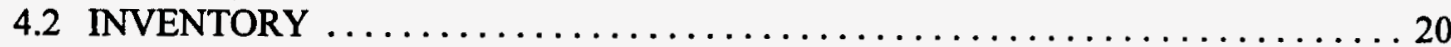

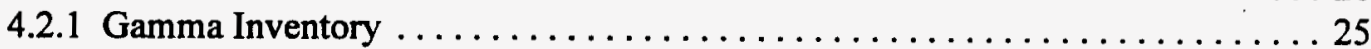

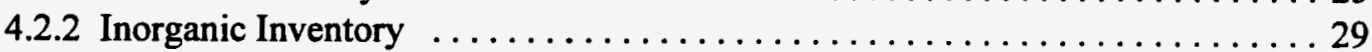

5. WALKOVER GAMMA ANALYSIS COMPARISON $\ldots \ldots \ldots \ldots \ldots \ldots \ldots \ldots \ldots \ldots \ldots \ldots \ldots$

5.1 SUMMARY OF THE RADIATION WALKOVER DATA $\ldots \ldots \ldots \ldots \ldots \ldots \ldots . \ldots \ldots$

5.2 COMPARISON OF CORE AND WALKOVER DATA $\ldots \ldots \ldots \ldots \ldots \ldots \ldots . \ldots \ldots$ 
6. HUMAN HEALTH EXPOSURE ASSESSMENT $\ldots \ldots \ldots \ldots \ldots \ldots \ldots \ldots \ldots \ldots \ldots$

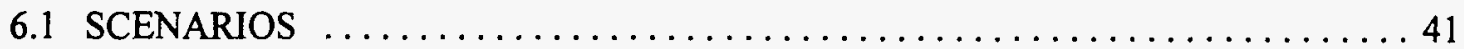

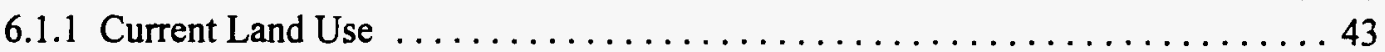

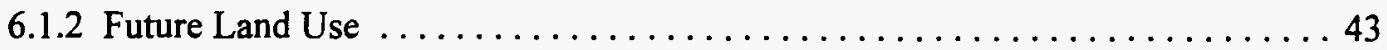

6.2 IDENTIFICATION OF EXPOSURE PATHWAYS $\ldots \ldots \ldots \ldots \ldots \ldots \ldots \ldots . \ldots 44$

6.2.1 Future On-WAG Industrial Scenario ..................... 44

6.2.2 Future On-WAG Residential Scenario $\ldots \ldots \ldots \ldots \ldots \ldots \ldots \ldots \ldots 4$

6.2.3 Future On-WAG Recreational Scenario ..................... 44

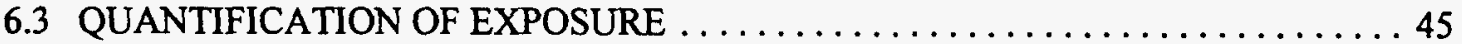

6.3.1 CDI Calculations for the Industrial Land Use Scenario . . . . . . . . . . . . 45

6.3.2 CDI Calculations for the Residential Land Use Scenario . . . . . . . . . . . 45

6.3.3 CDI Calculations for the Recreational Land Use Scenario . . . . . . . . . . . . 46

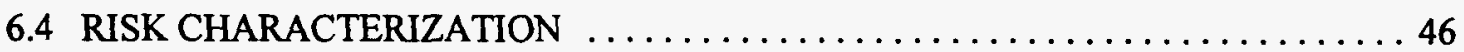

6.4.1 Evaluation of Carcinogens and Noncarcinogens $\ldots \ldots \ldots \ldots \ldots \ldots \ldots$

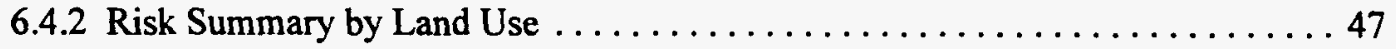

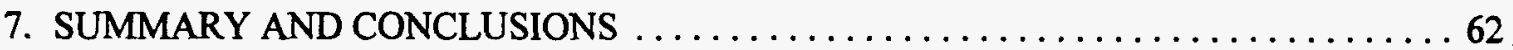

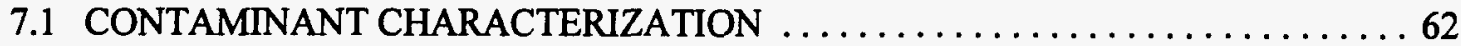

7.2 FLOODPLAIN RADIONUCLIDE INVENTORY $\ldots \ldots \ldots \ldots \ldots \ldots \ldots \ldots \ldots$

7.3 WALKOVER GAMMA ANALYSIS COMPARISON $\ldots \ldots \ldots \ldots \ldots \ldots \ldots \ldots$

7.4 HUMAN HEALTH EXPOSURE ASSESSMENT $\ldots \ldots \ldots \ldots \ldots \ldots \ldots \ldots \ldots$

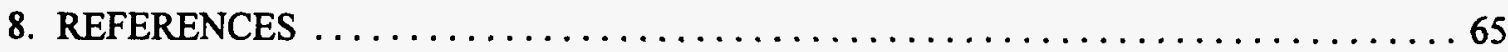

APPENDIX A: QUALITY CONTROL DATA FOR INORGANIC, ORGANIC, TRANSURANIC, AND BETA SOIL AND SEDIMENT SAMPLES $\ldots \ldots \ldots \ldots \ldots \ldots$ A-1

APPENDIX B: SUMMARY OF RESULTS FROM SOIL AND SEDIMENT SAMPLES

FROM THE WAG 2 FLOODPLAIN $\ldots \ldots \ldots \ldots \ldots \ldots \ldots \ldots \ldots \ldots \ldots \ldots \ldots \ldots \ldots \ldots \ldots$

APPENDIX C: MAP LOCATIONS CORRESPONDING TO SAMPLE

IDENTIFICATION NUMBERS AND SEDIMENT CORE PLOTS

FOR ${ }^{137} \mathrm{CS}$ AND ${ }^{60} \mathrm{CO}$ IN THE WHITE OAK CREEK FLOODPLAIN 


\section{FIGURES}

Figure

Page

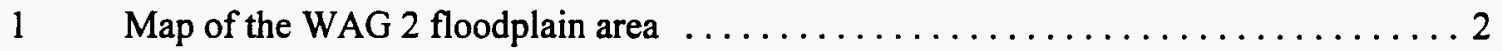

2 Concentrations of ${ }^{60} \mathrm{Co}$ in the WAG 2 floodplain soils and sediments $\ldots \ldots \ldots 14$

3 Concentrations of ${ }^{137} \mathrm{Cs}$ in the WAG 2 floodplain soils and sediments $\ldots \ldots \ldots \ldots 15$

4 Selected profiles of ${ }^{137} \mathrm{Cs}$ and ${ }^{60} \mathrm{Co}$ with depth in the WAG 2 floodplain soils

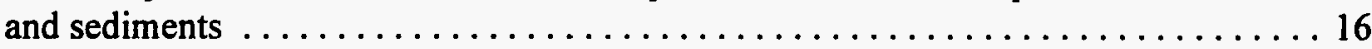

5 Relative proportions calculated from mean of selected alpha- and betaemitting radionuclides in WAG 2 floodplain soils and sediments $\ldots \ldots \ldots \ldots \ldots 18$

6 Relative proportions calculated from mean long-lived alpha-emitting radionuclide activities in WAG 2 floodplain soils and sediments . . . . . . . . 19

7 Mean antimony concentrations \pm 1 SD in WAG 2 floodplain soils

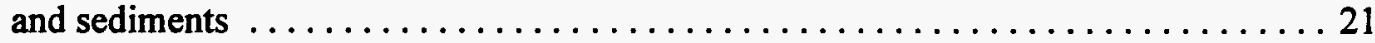

8 Mean chromium concentrations \pm 1 SD in WAG 2 floodplain soils

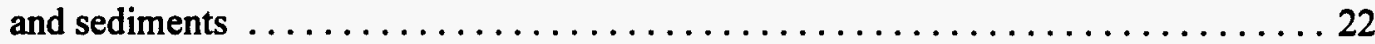

9 Mean mercury concentrations \pm 1 SD in WAG 2 floodplain soils

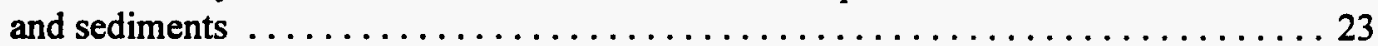

10 Mean nickel concentrations \pm 1 SD in WAG 2 floodplain soils and sediments $\ldots \ldots 24$

11 Inventory of ${ }^{137} \mathrm{Cs}$ corresponding to a $10^{-4}$ human health risk $\ldots \ldots \ldots \ldots \ldots$

12 Inventory of ${ }^{137} \mathrm{Cs}$ corresponding to a $10^{-2}$ human health risk $\ldots \ldots \ldots \ldots \ldots \ldots$

13 Radiation walkover measurements of WAG 2, mapped as contour data ........ 33

14 Cumulative dose for a uniform contaminant distribution and a soil density of $1.6 \mathrm{~g} / \mathrm{cm}^{3}$, normalized by dose from the entire $60 \mathrm{~cm}$ layer for ${ }^{137} \mathrm{Cs}$ and ${ }^{60} \mathrm{Co} \ldots \ldots 35$

$15 \log _{10}-\log _{10}$ plot of gamma walkover data vs the dose equivalent calculated from soil and sediment cores in the WAG 2 floodplain

16 Location of walkover measurements (small dots) and core samples (large dots) for the confluence of Melton Branch and White Oak Creek .............. 38

17 Exposure rates based on the walkover data for the WAG 2 floodplain $\ldots \ldots \ldots \ldots 39$

18 Preliminary conceptual model for all receptors on WAG $2 \ldots \ldots \ldots \ldots \ldots \ldots \ldots 2$ 
C.1 Map of sampling sites in the investigation of contamination in WAG 2

floodplain soils

C.2 Sampling sites and identification numbers of samples collected in the Intermediate Holding Pond area (Fig. C-1, box A) as part of the investigation of contamination in WAG 2 floodplain soils

C.3 Sampling sites and identification numbers of samples collected in the Lower White Oak Creek area (Fig. C-1, box B) as part of the investigation of contamination in WAG 2 floodplain soils

C.4 Sampling sites and identification numbers of samples collected in the Middle White Oak Creek and Lower Melton Branch Creek areas (Fig. C-1, box C) as part of the investigation of contamination in WAG 2 floodplain soils . . . . C-6

C.5 Sampling sites and identification numbers of samples collected in the Middle Melton Branch Creek and Upper Melton Branch Creek areas (Fig. C-1, box D) as part of the investigation of contamination in WAG 2 floodplain soils

C.6 Plots of ${ }^{137} \mathrm{Cs}$ concentrations (asterisks) and ${ }^{60} \mathrm{Co}$ concentrations (stars) in sediment sampled during 1995 at sites $1000,1010,1011,1012,1013$, 1014,1015 , and 1016 .

C.7 Plots of ${ }^{137} \mathrm{Cs}$ concentrations (asterisks) and ${ }^{60} \mathrm{Co}$ concentrations (stars) in sediment sampled during 1995 at sites $1017,1018,1019,1020,1026$, 1031,1034 , and 1038 .

C.8 Plots of ${ }^{137} \mathrm{Cs}$ concentrations (asterisks) and ${ }^{60} \mathrm{Co}$ concentrations (stars) in sediment sampled during 1995 at sites $1043,1046,1049,1052,1065$, 1066,1067 , and 1068

C.9 Plots of ${ }^{137} \mathrm{Cs}$ concentrations (asterisks) and ${ }^{60} \mathrm{Co}$ concentrations (stars) in sediment sampled during 1995 at sites $1069,1070,1071,1072,1073$, 1074,1075 , and 1076

C.10 Plots of ${ }^{137} \mathrm{Cs}$ concentrations (asterisks) and ${ }^{60} \mathrm{Co}$ concentrations (stars) in sediment sampled during 1995 at sites $1077,1078,1079,1080,1081$, 1082,1083 , and 1084

C.11 Plots of ${ }^{137} \mathrm{Cs}$ concentrations (asterisks) and ${ }^{60} \mathrm{Co}$ concentrations (stars) in sediment sampled during 1995 at sites $1085,1086,1087,1088,1089$, 1090, 1091, and 1092 
C.12 Plots of ${ }^{137} \mathrm{Cs}$ concentrations (asterisks) and ${ }^{60} \mathrm{Co}$ concentrations (stars) in sediment sampled during 1995 at sites 1093, 1094, 1095, 1096, 1097, 1098,1099 , and 1100 .

C.13 Plots of ${ }^{137} \mathrm{Cs}$ concentrations (asterisks) and ${ }^{60} \mathrm{Co}$ concentrations (stars) in sediment sampled during 1995 at sites $1101,1102,1103,1122,1123$, 1124,1125 , and 1126

C.14 Plots of ${ }^{137} \mathrm{Cs}$ concentrations (asterisks) and ${ }^{60} \mathrm{Co}$ concentrations (stars) in sediment sampled during 1995 at sites $1127,1128,1129,1132,1133$, 1134,1135 , and 1136

C.15 Plots of ${ }^{137} \mathrm{Cs}$ concentrations (asterisks) and ${ }^{60} \mathrm{Co}$ concentrations (stars) in sediment sampled during 1995 at sites $1137,1138,1139,1142,1144$, 1153,1154 , and 1155

C.16 Plots of ${ }^{137} \mathrm{Cs}$ concentrations (asterisks) and ${ }^{60} \mathrm{Co}$ concentrations (stars) in sediment sampled during 1995 at sites $1156,1157,1158,1159,1160$, 1161,1162 , and 1163

C.17 Plots of ${ }^{137} \mathrm{Cs}$ concentrations (asterisks) and ${ }^{60} \mathrm{Co}$ concentrations (stars) in sediment sampled during 1995 at sites $1164,1165,1166,1167,1168$, 1169,1170 , and 1171

C.18 Plots of ${ }^{137} \mathrm{Cs}$ concentrations (asterisks) and ${ }^{60} \mathrm{Co}$ concentrations (stars) in sediment sampled during 1995 at sites $1173,1174,1175,1176,1177$,

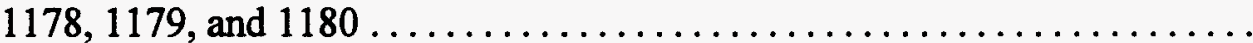

C.19 Plots of ${ }^{137} \mathrm{Cs}$ concentrations (asterisks) and ${ }^{60} \mathrm{Co}$ concentrations (stars) in sediment sampled during 1995 at sites $1181,1182,1186,1187,1188$, 1189,1190 , and 1191

C.20 Plots of ${ }^{137} \mathrm{Cs}$ concentrations (asterisks) and ${ }^{60} \mathrm{Co}$ concentrations (stars) in sediment sampled during 1995 at sites $1192,1193,1194,1195,1196$, 1197,1198 , and 1199

C.21 Plots of ${ }^{137} \mathrm{Cs}$ concentrations (asterisks) and ${ }^{60} \mathrm{Co}$ concentrations (stars) in sediment sampled during 1995 at sites $1200,1201,1202,1203,1204$, 1205,1206 , and 1207

C.22 Plots of ${ }^{137} \mathrm{Cs}$ concentrations (asterisks) and ${ }^{60} \mathrm{Co}$ concentrations (stars) in sediment sampled during 1995 at sites 1208 and $1209 \ldots \ldots \ldots \ldots \ldots$. 24 


\section{TABLES}

Table

1 Number of samples for each analytical class collected from each area, as found

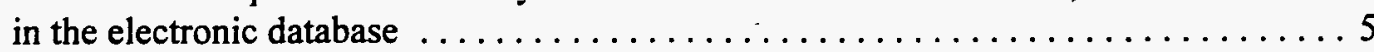

2 Listing of requested analyses for each analytical grouping from database records . . 10

3 Estimates of gamma-emitting radionuclide inventories on the basis of ratios from soil and sediment cores in the WAG 2 floodplain $\ldots \ldots \ldots \ldots \ldots \ldots \ldots \ldots$

4 Estimates of transuranic radionuclide inventories on the basis of ratios from soil and sediment cores in the WAG 2 floodplain $\ldots \ldots \ldots \ldots \ldots \ldots \ldots \ldots \ldots \ldots \ldots \ldots \ldots$

5 Dose equivalent data for ${ }^{137} \mathrm{Cs},{ }^{137} \mathrm{Ba},{ }^{137} \mathrm{Cs}$ combined with ${ }^{137} \mathrm{Ba}$, and ${ }^{60} \mathrm{Co}$ for plane

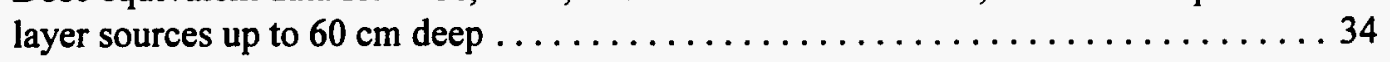

6 Summary of carcinogenic risk for WAG 2 sediment on the basis of the residential land use scenario $(0-$ to 15 -cm-depth samples $) \ldots \ldots \ldots \ldots \ldots \ldots \ldots \ldots \ldots \ldots \ldots \ldots \ldots$

7 Summary of carcinogenic risk for WAG 2 sediment on the basis of the recreational land use scenario $(0-$ to $15-\mathrm{cm}$-depth samples) $\ldots \ldots \ldots \ldots \ldots \ldots \ldots \ldots \ldots \ldots \ldots \ldots \ldots \ldots \ldots$

8 Summary of carcinogenic risk for WAG 2 sediment on the basis of the industrial land use scenario $(0-$ to 15 -cm-depth samples $) \ldots \ldots \ldots \ldots \ldots \ldots \ldots \ldots \ldots \ldots \ldots \ldots \ldots \ldots \ldots$

9 Summary of total carcinogenic risk for areas in WAG $2 \ldots \ldots \ldots \ldots \ldots \ldots \ldots$

10 Summary of hazard quotients for noncarcinogenic effects for WAG 2 sediment on the basis of the residential land use scenario ( 0 - to 15 -cm-depth samples) $\ldots \ldots 55$

11 Summary of hazard quotients for noncarcinogenic effects for WAG 2 sediment on the basis of the recreational land use scenario (0- to 15 -cm-depth samples) $\ldots \ldots 56$

12 Summary of hazard quotients for noncarcinogenic effects for WAG 2 sediment based on industrial land use scenario $(0$ - to 15 -cm-depth samples) $\ldots \ldots \ldots \ldots \ldots 58$

13 Summary of hazard indices for noncarcinogenic effects for WAG 2 areas .......59

14 Summary comparison of external exposure risk based on USRADS walkover data, HEDOSE model output, and measured soil-sediment core concentrations . . . . 60

A.1 Results of inorganic soil samples submitted for quality control (QC) analysis as part of the WAG 2 floodplain soil and sediment characterization and inventory 
A.2 Results of organic soil blank samples submitted for quality control (QC) analysis

A.3 Results of transuranic and beta soil samples submitted for quality control (QC)

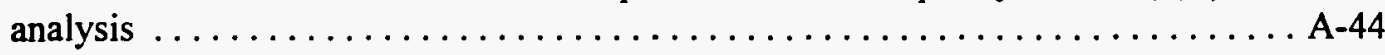

B.1 Summary of gamma values for WAG 2 floodplain soil and stream sediments ..... B-3

B.2 Summary of transuranic and beta values for WAG 2 floodplain soil and sediment .. B-4

B.3 Summary of inorganics for WAG 2 floodplain soil and sediment $\ldots \ldots \ldots \ldots$. . .

B.4 Decay-corrected estimates of ${ }^{137} \mathrm{Cs}$ in the White Oak Creek watershed ........ B-22 


\section{ABBREVIATIONS}

$\begin{array}{ll}\text { CDI } & \text { chronic daily intake } \\ \text { CERCLA } & \text { Comprehensive Environmental Response Compensation and Liability Act } \\ \text { COCs } & \text { contaminants of concern } \\ \text { COPCs } & \text { contaminants of potential concern } \\ \text { DOE } & \text { U.S. Department of Energy } \\ \text { DQO } & \text { data quality objective } \\ \text { EPA } & \text { U.S. Environmental Protection Agency } \\ \text { HFIR/TPP } & \text { High Flux Isotope Reactor/Transuranic Processing Plant } \\ \text { HI } & \text { Hazard Index } \\ \text { HQ } & \text { hazard quotient } \\ \text { ICP } & \text { inductively coupled plasma } \\ \text { IHP } & \text { Intermediate Holding Pond } \\ \text { LMBC } & \text { Lower Melton Branch Creek } \\ \text { LWOC } & \text { Lower White Oak Creek } \\ \text { MB } & \text { Melton Branch } \\ \text { MMBC } & \text { Middle Melton Branch Creek } \\ \text { MWOC } & \text { Middle White Oak Creek } \\ \text { ORNL } & \text { Oak Ridge National Laboratory } \\ \text { ORR } & \text { Oak Ridge Reservation } \\ \text { PCBs } & \text { polychlorinatedbiphenyls } \\ \text { QC } & \text { quality control } \\ \text { RfC } & \text { reference concentration } \\ \text { RfD } & \text { reference dose } \\ \text { RI } & \text { remedial investigation } \\ \text { RME } & \text { reasonable maximum exposure } \\ \text { RPD } & \text { relative percent difference } \\ \text { SF } & \text { slope factor } \\ \text { SWSA } & \text { solid waste storage area } \\ t / 1 / & \text { radioactive half-life } \\ \text { TRU } & \text { transuranic } \\ \text { USRADS } & \text { Ultra Sonic Ranging and Data System } \\ \text { UMBC } & \text { Upper Melton Branch Creek } \\ \text { UWOC } & \text { Uppoer White Oak Creek } \\ \text { WAG } & \text { waste area grouping } \\ \text { WOC } & \text { White Oak Creek } \\ \text { WOL } & \text { White Oak Lake } \\ & \end{array}$




\section{EXECUTIVE SUMMARY}

A remedial investigation was conducted to determine the extent and type of contamination in the floodplain soils of Waste Area Grouping (WAG) 2, in conjunction with environmental restoration activities at the U.S. Department of Energy (DOE) Oak Ridge Reservation (ORR). The WAG 2 floodplain area, located downstream from the main Oak Ridge National Laboratory (ORNL) plant area, and upstream from White Oak Lake (WOL), receives surface drainage from several major ORNL WAGs. It has been exposed to a wide variety of contaminants, principally the gamma-emitting radionuclides ${ }^{137} \mathrm{Cs}$ and ${ }^{60} \mathrm{Co}$. Other contaminants include transuranic and beta-emitting radionuclides, organics and metals.

The WAG 2 floodplain soil and stream sediment investigation was initiated to determine if contaminants associated with soils or sediments pose an imminent, and unknown, risk to exposed populations and to quantify the inventory of key contaminants in the soils and sediments of WAG 2. Activities conducted to address these data gaps included (1) Radiological walkover of the floodplain to estimate the extent of contamination and identify hot spots, (2) Sampling of floodplain soils and stream sediments to characterize contaminants, and (3) Human health exposure assessment. The WAG 2 floodplain includes White Oak Creek (WOC) from WOL to the 7500 bridge at WAG 1, and Melton Branch (MB) from the WOC-MB confluence to the borders of WAGs 5 and 8. For the purposes of this study, the floodplain was divided into (1) Intermediate Holding Pond (IHP) and Middle White Oak Creek (MWOC) areas located on WOC upstream of the WOC-MB confluence; (2) Upper, Middle, and Lower Melton Branch Creek areas (UMBC, MMBC, LMBC, respectively), located on MB upstream of the WOC-MB confluence; and (3) Lower WOC (LWOC), located on WOC downstream from the WOC-MB confluence and upstream of WOL.

Contaminant characterization results indicated that the primary contaminants in the WAG 2 floodplain area are the gamma-emitting radionuclides ${ }^{137} \mathrm{Cs}$ and ${ }^{60} \mathrm{Co}$, although ${ }^{60} \mathrm{Co}$ activity levels are $1 / 25$ or less than those of ${ }^{137} \mathrm{Cs}$. No other gamma emitting radionuclides were detected during gamma-spectometric analysis of soil or sediment core samples. The highest levels of ${ }^{137} \mathrm{Cs}$ with a 30 -year radioactive half-life $\left(t_{1 / 7}\right)$ were in the Intermediate Holding Pond (IHP) area, and high levels were also observed in the LWOC reach. ${ }^{60} \mathrm{Co}\left(t_{1 / 2} 5.3\right.$ years) activities were highest in Melton Branch, particularly UMBC and MMBC. For gamma-emitting radionuclides, contaminant levels were generally highest near the surface sediments and decreased with depth toward the bottom. No general trends in contaminant concentration with distance from the WOC stream channel was observed.

The beta-emitting radionuclides ${ }^{89 / 90} \mathrm{Sr}$ and ${ }^{99} \mathrm{Tc}$ were predominately detected in MMBC (Seep C) and LWOC, respectively. Highest concentrations of the relatively short-lived alphaemitting radionuclides ${ }^{244} \mathrm{Cm},{ }^{241} \mathrm{Am}$ and ${ }^{238} \mathrm{Pu}$ (all with $t_{1 / 2}<450$ years) were found in Seep $\mathrm{C}$ of the MMBC and the IHP. The relative proportions of the remaining alpha-emitting radionuclides (all with $t_{1 / 2}$ from $6.5 \times 10^{3}$ to $1.1 \times 10^{10}$ years) were predominantly found in the IHP area, although the highest levels of ${ }^{233 / 234} \mathrm{U}$ were observed in the LWOC.

Inorganic contaminants discussed in this report were limited to those contributing significantly to human health exposure [ $\mathrm{Sb}, \mathrm{Ba}, \mathrm{Cr}(\mathrm{IV}), \mathrm{Mn}, \mathrm{Hg}$, and $\mathrm{Ni}]$. The distribution of $\mathrm{Mn}$ reflects natural processes rather than anthropogenic sources. The highest levels of $\mathrm{Ba}$ and $\mathrm{Cr}(\mathrm{IV})$ were observed in the Melton Branch weirs, suggesting a source in the Melton Branch 
watershed; $\mathrm{Cr}(\mathrm{IV})$ levels were significantly higher in MMBC than at other sites in the WAG 2 floodplain. $\mathrm{Hg}$ and $\mathrm{Ni}$ were highest in the IHP, reflecting historic releases of these contaminants from operations at ORNL. No significant differences in $\mathrm{Hg}$ or Ni concentrations were observed between areas in the WAG 2 floodplain.

Based on soil core samples, the total inventory of gamma-emitting radionuclides was estimated to be 198.6 curies ( $\mathrm{Ci}$ ) for the WAG 2 floodplain; this may be an overestimate because the distribution of the cores throughout WAG 2 was nonrandom. The largest inventories were estimated in the IHP, with approximately $125 \mathrm{Ci}$ of ${ }^{137} \mathrm{Cs}, 0.47 \mathrm{Ci}$ of ${ }^{8990} \mathrm{Sr}, 0.32 \mathrm{Ci}$ of ${ }^{60} \mathrm{Co}$, and $0.1 \mathrm{Ci}$ of ${ }^{239 / 240} \mathrm{Pu}$. Other radionuclide inventories were estimated to be less than $0.1 \mathrm{Ci}$ in the IHP. The highest estimated inventories of ${ }^{241} \mathrm{Am},{ }^{244} \mathrm{Cm},{ }^{238} \mathrm{Pu},{ }^{239 / 240} \mathrm{Pu},{ }^{99} \mathrm{Tc},{ }^{228} \mathrm{Th},{ }^{230} \mathrm{Th}$, ${ }^{233 / 234} \mathrm{U}$, and ${ }^{238} \mathrm{U}$ were in the $\mathrm{LWOC}$ reach; ${ }^{239 / 240} \mathrm{Pu}$ and ${ }^{99} \mathrm{Tc}$ had the highest estimates, with $0.2 \mathrm{Ci}$ each.

From comparisons of walkover data and gamma data from soil and sediment cores, it is apparent that the walkover-gamma survey successfully identified areas of elevated gamma concentrations (hot spots) because the contamination was near the surface. Judged on the basis of the gamma calculations generated from core analyses, the walkover data correlate well with the soil concentrations in highly contaminated areas but may overestimate the extent of contamination adjacent to these areas as a result of gamma shine. As expected, walkover data appear to be a better indicator of external exposure than core data, a function of more complete coverage and the incorporation of gamma-shine, an important contributor to external exposure. The HEDOSE program was developed through the use of these walkover and soil core data. Its purpose, to calculate effective dose from core data is of potential benefit for comparing remediation alternatives. HEDOSE could be used, for example, to investigate the consequences of soil erosion exposing deeper contamination or the benefits of placing a layer of clean soil over the most highly contaminated areas.

Human health exposure assessment results indicate that for the industrial and recreational land use scenarios, ${ }^{137} \mathrm{Cs}$ and ${ }^{60} \mathrm{Co}$ are the primary carcinogenic contaminants that exceed the target risk range of $1 \times 10^{-4}$ excess cancer risk from external exposure to WAG 2 floodplain soils. Results for the residential land use scenario, which is based on more conservative assumptions than the industrial or recreational scenarios, indicate that the carcinogenic contaminants of primary concern (with excess cancer risks $>1 \times 10^{-4}$ ) are ${ }^{137} \mathrm{Cs}$, ${ }^{60} \mathrm{Co},{ }^{239 / 240} \mathrm{Pu},{ }^{89 / 90} \mathrm{Sr},{ }^{228} \mathrm{Th},{ }^{241} \mathrm{Am}$, aroclor-1260, and ${ }^{244} \mathrm{Cm}$. External exposure to radionuclides, ingestion of produce, and ingestion of sediment were the exposure pathways primarily responsible for this excess cancer risk from these these contaminants.

Very few noncarcinogenic contaminants of concern [hazard quotent $(\mathrm{HQ})>0.1$ ] were observed in WAG 2. No contaminants for the industrial and recreational land use scenarios fit the noncarcinogen risk categories (HQ $>0.1$ or 1.0 ); therefore these pathways do not represent a concern for noncarcinogenic human health effects. For the residential land use scenario, the contaminants of primary concern (with $\mathrm{HQ}>1.0$ ) include $\mathrm{Mn}, \mathrm{Hg}$, aroclor- $1254, \mathrm{Cr}$, and $\mathrm{Sb}$, primarily via the ingestion of produce exposure pathway. In addition to the contaminants listed above, other contaminants of concern with HQs exceeding 0.1 include $\mathrm{Ni}$ and $\mathrm{Ba}$, through the ingestion of produce exposure pathway.

From the beginning, the WAG 2 remedial investigation (RI) has followed a phased approach; however, the Lockheed Martin Energy Systems Environmental Restoration Program 
has now adopted a watershed-wide approach to RIs, which will incorporate studies of all WAGs in a given creek watershed into a comprehensive RI. The result of the watershed-wide approach is that these results will not be included in a general $\mathrm{RI}$ report but are presented here to provide information for the WOC watershed RI report. These data will be available for use in the feasibility study of remedial actions for the WOC floodplain. 


\section{INTRODUCTION}

\subsection{REGULATORY INITIATIVE}

A remedial investigation was conducted to determine the extent and type of contamination in the floodplain soils of Waste Area Grouping (WAG) 2, in conjunction with environmental restoration activities at the U.S. Department of Energy (DOE) Oak Ridge Reservation (ORR). WAG 2 is located downstream from the main Oak Ridge National Laboratory (ORNL) plant area. As a result of past, present, and potential future releases of hazardous substances to the environment, the ORR was placed on the National Priorities List in December 1989 (54 Federal Register 48184). Sites on this list must be investigated to determine if remedial actions are possible, as required by the Comprehensive Environmental Response, Compensation, and Liability Act (CERCLA)[ (42 U.S.C. 6901, et seq.)]. This report documents the findings of the remedial investigation of the WAG 2 floodplain soils by (1) presenting the characterization and inventory of contaminants, (2) comparing the walkover survey data to quantitative gamma-emitting radionuclide data, and (3) presenting an assessment of human health risk from exposure to these soils. This investigation is authorized by Sect. 117 of CERCLA and was conducted in accordance with the requirements of the National Contingency Plan ( 40 Code of Federal Regulations Part 300).

DOE, the U.S. Environmental Protection Agency (EPA), and the Tennessee Department of Environment and Conservation have entered into a Federal Facility Agreement, as authorized by Sect. 120 of CERCLA and Sects. 3008(h) and 6001 of the Resource Conservation and Recovery Act (42 U.S.C. 6901 , et seq.). The purpose of this agreement is to ensure a coordinated and effective response for all environmental restoration activities occurring on the ORR. In addition to other responsibilities, the Federal Facilities Agreement parties mutually define the operable unit boundaries, set remediation priorities, establish remedial investigation priorities and strategies, and identify and select remedial actions (DOE 1996).

\subsection{SCOPE}

The work discussed in this report was performed as part of DOE's remedial investigation (RI) of WAG 2, which consists of White Oak Creek (WOC) and its tributaries downstream of the main ORNL plant area, White Oak Lake (WOL) and the White Oak Creek Embayment on the Clinch River, and the associated floodplain and subsurface environment. This report focuses on the investigation and characterization of floodplain soils upstream from WOL (Fig. 1). The WOC system is the surface drainage system for all major ORNL WAGs and as such, has been exposed to a wide variety of contaminants. WAG 2 acts as a conduit through which contaminants are carried from upgradient-WAGs to the Clinch River. Although water and biota in WAG 2 continue to receive contaminants from upgradient WAGs, floodplain soils in WAG 2 largely serve as repositories and sources for contaminants to areas downstream.

Remedial investigations and remedial actions are ongoing or planned for contaminated areas hydrologically upgradient of WAG 2 . These actions will effectively change the contaminant input as individual waste areas are remediated. Obviously, remedial actions undertaken in WAG 2 in the short term could be negated by future activities (either contaminant input or remediation upstream), and so the implementation of corrective measures in WAG 2 should 


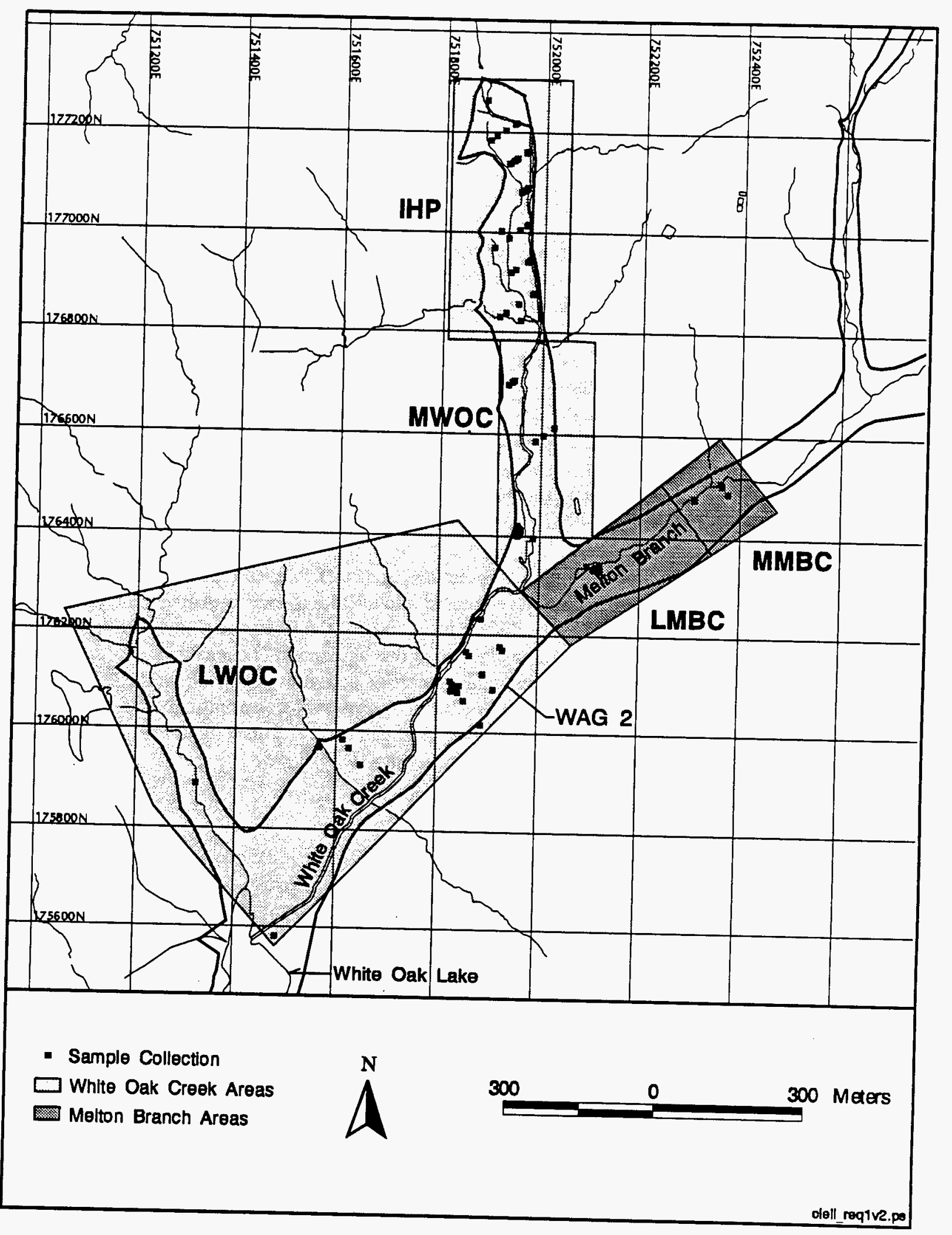

Fig. 1. Map of the WAG 2 floodplain area. 
follow completion of remedial activities in upgradient areas. However, this RI was initiated before upgradient WAGs were remediated for the following reasons: (1) information on current conditions was needed, (2) the WOC system acts as a conduit for contaminants, and (3) WAG 2 has accumulated sediments that may represent near-term hazards. From the beginning the WAG 2 RI has followed a phased approach; however, the Lockheed Martin Energy Systems Environmental Restoration Program has now adopted a watershed-wide approach to RIs, which will incorporate studies of all WAGs in a given creek watershed into a comprehensive RI. The result of the watershed-wide approach is that the constituents of the WAG 2 RI will not be included in a general RI report but will be presented as interim reports, providing information for the WOC watershed RI report.

\subsection{OBJECTIVES}

The WAG 2 floodplain soil and stream sediment investigation was initiated (1) to determine if contaminants associated with soils or sediments pose an imminent, and unknown, risk to exposed populations and (2) to quantify the inventory of key contaminants in the soils and sediments of WAG 2 . Five activities were conducted that address these data gaps:

1. radiological walkover - to estimate the extent of contamination and determine hot spots throughout the floodplain;

2. floodplain soil sampling- to characterize floodplain soils for inorganic, organic, and radiological contamination and to calculate contaminant inventories;

3. preliminary stream sediment sampling - to characterize stream sediments primarily at weir pools with regard to inorganic, organic, and radiological contamination and to calculate contaminant inventories;

4. comparison of radiological walkover and gamma analysis data; and

5. human health exposure assessment.

The results of this investigation are divided into three major categories: (1) contaminant characterization and inventory of floodplain soils and sediments (Sect. 4), (2) comparison of walkover survey results with soil and sediment core gamma data (Sect. 5), and (3) human health exposure assessment for floodplain soils and sediments (Sect. 6). These data will be available for use in the feasibility study of remedial actions for WAG 2 . 


\section{SITE HISTORY AND DESCRIPTION}

The WAG 2 floodplain encompasses $\sim 6.6$ hectares in both the WOC and Melton Branch (MB) watersheds (Table 1). For the purposes of this report, WAG 2 has been divided into six areas (Fig.1). The Intermediate Holding Pond (IHP) and Middle White Oak Creek (MWOC) areas are located on WOC upstream of the WOC-MB confluence. The Upper, Middle, and Lower Melton Branch Creek areas (UMBC, MMBC, LMBC respectively) are located on Melton Branch upstream of the WOC-MB confluence. The sixth area is Lower (LWOC), located on WOC downstream from the WOC-MB confluence and upstream of WOL.

\subsection{INTERMEDLATE HOLDING POND}

IHP is the area furthest upstream on WOC in WAG 2 and is located between the water gap in Haw Ridge and a location $\sim 0.5 \mathrm{~km}$ downstream. This area was the site impounded by a small $(90-\mathrm{m})$ earth-filled dam constructed in the spring of 1944 . Located $3.2 \mathrm{~km}$ upstream from the mouth of WOC, this pond was to serve as a settling basin for radionuclide-contaminated sediments released from ORNL and traveling down WOC toward WOL. In the fall of 1944, the earthen dam was breached by high water, and the pond was greatly diminished in size. During this time, $\sim 0.5 \mathrm{~m}$ of sediment, contaminated by radionuclide releases from ORNL, accumulated in the pond. The IHP bed originally covered $\sim 33,590 \mathrm{~m}^{2}$ (3.4 ha), but it had shrunk to $4850 \mathrm{~m}^{2}$ ( $0.5 \mathrm{ha}$ ) after the dam collapsed. Radionuclides, including alpha-, beta- and gamma-emitting radionuclides, are the primary known contaminants of concern (COCs) at this site. Numerous studies of the IHP (Clapp et al. 1995) report ${ }^{137} \mathrm{Cs}$ inventories in the 100 - to 800 -Ci range.

The treated waste discharged to the IHP site also contained plutonium, americium, and curium; these radionuclides were deposited in the IHP before moving downstream into WOL and WOC Embayment (Blaylock et al. 1993). Concentrations of ${ }^{239,240} \mathrm{Pu}$, ranging from 10 to 150 $\mathrm{pCi} / \mathrm{g}$, have been found with a total inventory of $0.5 \mathrm{Ci}$ over a 3-ha area. The highest concentration of ${ }^{239,240} \mathrm{Pu}$ occurred in the pond sediments between 0 and $10 \mathrm{~cm}$ (Dahlman et al. 1980).

Little information is available on inorganic or organic contaminants in the IHP area. However, any particle-associated contaminants released to WOC upstream of WAG 2 during the time frame of IHP should have accumulated to some extent in IHP. Samples for all other analytes were collected throughout the IHP area in a series of transects across WOC (Fig. 1).

\subsection{MIDDLE WHITE OAK CREEK}

The MWOC area, stretching $\sim 0.5 \mathrm{~km}$ from the former IHP dam to immediately below the WOC-MB confluence, receives the majority of its flow from IHP. The WOC weir, used to gage water flows for contaminant transport calculations and water-quality monitoring, is located in this area. Inventories in MWOC of historically released contaminants may be somewhat less than those for IHP because of the impounded nature of IHP during the 1940s. However, more recently released contaminants may show higher inventories in MWOC because of the sedimenttrapping nature of the weir. Most of the samples collected in MWOC were taken from the 
Table 1. Number of samples for each analytical class collected from each area, as found in the electronic database

\begin{tabular}{|c|c|c|c|c|c|c|c|c|c|c|c|}
\hline \multirow{3}{*}{ Area $^{a}$} & \multirow{3}{*}{$\begin{array}{l}\text { Size } \\
\text { (ha) }\end{array}$} & \multirow{3}{*}{$\begin{array}{c}\text { Number of } \\
\text { walk- } \\
\text { over } \\
\text { points }^{b}\end{array}$} & \multicolumn{5}{|c|}{ Floodplain soil } & \multicolumn{4}{|c|}{ Weir and seep sediment } \\
\hline & & & \multicolumn{2}{|c|}{ Gamma $^{c}$} & \multirow[b]{2}{*}{ Inorganic } & \multirow[b]{2}{*}{ Organic } & \multirow{2}{*}{$\begin{array}{c}\mathrm{TRU}^{d} \\
\text { and } \\
\text { beta }\end{array}$} & \multicolumn{2}{|c|}{ Gamma $^{c}$} & \multirow[b]{2}{*}{ Inorganic } & \multirow{2}{*}{$\begin{array}{r}\text { TRU }^{d} \\
\text { and } \\
\text { beta }\end{array}$} \\
\hline & & & $\begin{array}{l}\text { No. of } \\
\text { composite } \\
\text { cores }\end{array}$ & $\begin{array}{l}\text { No. of } \\
\text { section } \\
\text { cores }\end{array}$ & & & & $\begin{array}{l}\text { No. of } \\
\text { composite } \\
\text { cores }\end{array}$ & $\begin{array}{l}\text { No. of } \\
\text { section } \\
\text { cores }\end{array}$ & & \\
\hline MWOC & 0.63 & 29,160 & 5 & $29(5)$ & 2 & 2 & 3 & 6 & $68(11)$ & 5 & 5 \\
\hline LWOC & 4.55 & 223,560 & 9 & $263(11)$ & 8 & 54 & 20 & 4 & $41(13)$ & 4 & 2 \\
\hline UMBC & 0.04 & 3,240 & 0 & 0 & 0 & 0 & $\mathbf{0}$ & 4 & $9(9)$ & 2 & 2 \\
\hline MMBC & 0.19 & 9,720 & 6 & $34(6)$ & 2 & 2 & 2 & 0 & 0 & 4 & 5 \\
\hline Total & 6.60 & 324,000 & 78 & 574 & 22 & 58 & 45 & 30 & 243 & 23 & 20 \\
\hline
\end{tabular}

${ }^{\circ}$ Intermediate Holding Pond (IHP), Middle White Oak Creek (MWOC), Lower White Oak Creek (LWOC), Upper Melton Branch Creek (UMBC), Middle Melton Branch Creek (MMBC), Lower Melton Branch Creek (LMBC).

${ }^{b}$ The number of walkover points are approximate, based on the surface area of each group as given in the second column.

${ }^{c}$ Gamma values are listed for both composited cores and individual sections for soil and sediment; numbers in parentheses indicate the number of different core depths from which the samples were collected.

${ }^{t}$ TRU = transuranic. 
vicinity of the WOC weir, with a few samples collected upstream toward IHP (Fig. 1). As with IHP, little is known about inorganic or organic contaminants in MWOC.

\subsection{MELTON BRANCH}

The soil and sediment samples from the WAG 2 portion of Melton Branch were mostly collected in LMBC ( 0.33 ha, located $\sim 0.3 \mathrm{~km}$ upstream from the WOC confluence) and MMBC $(\sim 0.19 \mathrm{ha}$, an additional $100 \mathrm{~m}$ upstream). Melton Branch has received releases from the High Flux Isatope Reactor/Transuranic Processing Plant (HFIR/TPP), as well as from other waste disposal areas nearby, and may be expected to have released transuranic contaminants further downstream. Additionally, ${ }^{60} \mathrm{Co}$ and ${ }^{137} \mathrm{Cs}$ have been released to Melton Branch from processes at HFIR/TPP and are also expected to be found in Melton Branch soils and sediments. The most significant source of contaminants to Melton Branch is contaminated groundwater from WAG 5 , which is the northwestern border of WAG 2 in this area (Fig. 1). The groundwater, containing ${ }^{90} \mathrm{Sr}$ and ${ }^{3} \mathrm{H}$, enters MMBC through Seep C. Elevated levels of ${ }^{90} \mathrm{Sr}$ are observed in the immediate vicinity of Seep C, although it is not expected to be observed at high levels in other areas of WAG 2 floodplain soils or sediments.

\subsection{LOWER WHITE OAK CREEK}

The LWOC area ( $4.55 \mathrm{ha}$ ) extends from the most upstream extent of WOL to immediately below the WOC-MB confluence (Fig. 1). It also includes the West Seep tributary from WAG 7, which flows directly into WOL outside of the study area. The bulk of LWOC constitutes the former bed and floodplain of WOL (originally $\sim 14.5$ ha, currently $\sim 7$ ha) and as such, contains substantial amounts of radionuclide and other sediment-borne contaminants, deposited when the area was inundated by WOL or by seasonal high waters. The WOL floodplain portion may be expected to have contaminant levels and inventories similar to that of the upstream areas. West Seep weir pool sediments, which should contain contaminants characteristic of WAG 7, were also sampled. 


\section{METHODS}

\subsection{GAMMA WALKOVER STRATEGY}

Preliminary screening of WAG 2 soils identified ${ }^{137} \mathrm{Cs}$ as the primary contributor to human health risk (Boston et al. 1992). The Melton Branch Creek and WOC floodplains were systematically surveyed; gamma radiation intensity was measured using a sodium iodide (NaI) detector a few centimeters above the ground and at a height of $1 \mathrm{~m}$. This survey was conducted before soil and stream sediment samples were collected for radiological and chemical analysis; survey data were not collected from stream channel areas, or other areas covered by water. This walkover survey, using an Ultrasonic Ranging and Data System (USRADS ${ }^{\circledR}$ ), was conducted to (1) guide subsequent soil sampling to estimate the extent of soil and sediment contamination; (2) locate and define hot spots; (3) provide preliminary information for gamma contamination for major areas of the WAG 2 floodplain which had previously not been characterized; and (4) provide gamma data for human health exposure assessment.

These data formed the basis of soil sampling efforts by stratifying the floodplain into contaminated zones and identifying areas potentially requiring interim corrective measures. A hot spot is quantitatively defined as any area where walkover measurements exceeded the dose rate in the immediately surrounding area by $>300 \%$. On the basis of the walkover survey data, the WAG 2 team collected core samples to determine the depth distribution of the radionuclides and to answer two key questions about the validity of the gamma walkover data: (1) Does gamma-shine from hot spots seriously affect the quality of the measurements in adjacent areas? (2) Does the walkover data accurately delineate the contaminated areas or are there areas where the stream has covered contaminated sediments with clean soil, shielding the contaminated layer and preventing detection by the walkover survey?

The walkover survey was discussed in the Environmental Restoration Monitoring and Assessment Report (Clapp et al. 1995). The walkover survey covered the whole area of WAG 2, resulting in $\sim 324,000$ individual data points, which were used to calculate exposure to gammaemitting radionuclides. Because this data set is more extensive than the actual chemical and radiological soil analysis data set, and because it measures external exposure directly, the gamma walkover data set was used to calculate external exposure risk in the human health risk assessment (Sect. 6). Where sufficient gamma-emitting radionuclide data exist, human health risk from external exposure will also be calculated through the use of radiological data. The relationship between walkover data and radiological data is explored in Sect. 5. The number of walkover survey points per area is presented in Table 1 .

Section 5 of this report briefly summarizes the results of the walkover survey. The program HEDOSE, which was developed for this project, was designed to predict dose to an individual standing on the surface of contaminated soil on the basis of the core data. The HEDOSE program was used to compare the core and walkover data. Through this comparison, the utility of walkover data to reliably delineate the main areas of contamination within WAG 2 (as verified with core data) can be determined, and human health exposure to direct gamma radiation can be assessed. The usefulness of the HEDOSE program as a tool for investigating remediation alternatives may also be determined. 


\subsection{SOIL AND SEDIMENT COLLECTION STRATEGY}

Gamma walkover data were used to guide the selection of sample sites used to determine the depth distribution of radionuclides. Floodplain soils and weir sediment samples were collected by using two different approaches. Within the floodplain, one soil core sample for gamma-emitting radionuclides was collected from sites with anomalously high $(>300 \%$ than dose rate in immediate vicinity) walkover exposures. For large anomalies with no distinct hot spots, one core was collected every $50 \mathrm{~m} \times 50 \mathrm{~m}$ square. Depth profile samples were collected and analyzed for gamma-emitting radionuclides to determine the vertical distribution of gammaemitting contaminants in the upper $0.5 \mathrm{~m}$ of the soil. Half of the samples were composited over the entire depth. The other half (chosen randomly) of the samples were sectioned into the top 5 $\mathrm{cm}$ with $10 \mathrm{~cm}$ intervals thereafter. After partitioning as appropriate, each sample was homogenized before analysis. The detailed depth profile information was compared with the walkover data to determine (1) how accurately the walkover data predicts measured quantities of gamma-emitting radionuclides and (2) the extent that walkover data can be used to replace actual measurement of gamma-emitting radionuclides (Sect. 5). The distribution of soil and sediment samples collected for gamma-emitting radionuclide analysis among the areas as well as the number of composites and sections from each core are presented in Table 1.

Twenty soil samples, chosen randomly in the vicinity of Solid Waste Storage Area (SWSA) 5 and the IHP area, were analyzed for specific transuranic and beta-emitting radionuclides. Forty samples from the areas with anomalously high gamma radiation were chosen randomly from the remaining samples for analysis of polychlorinatedbiphenyls (PCBs), chlordane, and metals [inductively coupled plasma (ICP) analysis was used for metals and cold vaper atomic absorption analysis was used for mercury]. Additionally, ten sites where walkover data showed no anomalous radiation were selected at random for collection of 30-cm-deep composite core samples; these data were used to test the hypothesis that both radiological and nonradiological contaminants are found at the same locations and therefore deposition processes were the same for all radionuclides. For gamma-emitting radionuclides and walkover data, the number of soil cores per area analyzed for each of these categories is presented in Table 1.

Sediment from the two lower weirs on WOC (7500 Bridge in IHP and MWOC), the two lower weirs on Melton Branch, and the West Seep weir were sampled and analyzed for all contaminants. Two cores (up to $100 \mathrm{~cm}$ depth) were collected by using a hand-held corer from each pool; cores were sectioned into the upper $10 \mathrm{~cm}$ and the remaining depth. All samples were homogenized and analyzed for gamma-emitting radionuclides, ${ }^{90} \mathrm{Sr}$, ICP- metals, mercury, semivolatile organics, PCBs, and pesticides. In addition, the upper $10 \mathrm{~cm}$ of each core was analyzed for selected transuranics and beta-emitting radionuclides. The actual number of sediment core samples per analytical group for each area are presented in Table 1.

\subsection{FIELD SAMPLING AND PROCESSING}

The gamma radiation walkover survey of WAG 2 was conducted through the use of handheld gamma detectors in conjunction with USRADS ${ }^{\oplus}$ originally developed at ORNL and further refined by Chemrad Tennessee (Nyquist and Blair 1991). USRADS ${ }^{\circledast}$ records the surveyors position and instrument readings once each second as the surveyor walks. At a normal walking pace, this corresponds to a measurement about every $2 \mathrm{ft}$, an extremely dense sampling interval. 
A Ludlam Model 19 gamma scintillometer was used to record radiation levels near the ground and a Ludlam micro-R meter to record dose rate $1 \mathrm{~m}$ above ground. Both instruments use a NaI crystal to detect the gamma radiation, and both instruments were calibrated for ${ }^{137} \mathrm{Cs}$, the principle gamma-emitting isotope at WAG 2.

Field collection and processing techniques varied depending on the analytical category of the samples to be submitted. All soil and sediment core samples were collected with a hand auger, following environmental surveillance procedures (Kimbrough et al. 1990), modified to fit observed environmental conditions; all modifications to specified procedures were documented in the field activity logbook for the particular collection dates. Specific procedures are listed in Table 3.2 of the field sampling and analysis plan for the remedial investigation of WAG 2 (Boston et al. 1992).

\subsection{LABORATORY ANALYSES}

The analytes specified for this investigation are listed in Table 2. Analytical techniques to be used by external laboratories for chemical and radiological analyses are specified in Table 3.3 of the field sampling and analysis plan (Boston et al. 1992). All analyses conducted by laboratories external to ORNL's Environmental Sciences Division were conducted in accordance with Lockheed Martin Energy Systems Analytical Project Office Statement of Work-118 (MMES 1993).

Analysis of samples for gamma-emitting radionuclides was completed in-house with $\mathrm{NaI}$ detectors linked to the Accuspec system. This system had largely been relegated to performing screening-level analyses, having been replaced by germanium-lithium ( $\mathrm{GeLi})$ detectors; samples from sites with lower levels of gamma-emitting radionuclide contamination, such as off-site aquatic environments, were analyzed using the more sensitive GeLi system. However, because of the higher cost of using the GeLi system, coupled with the high levels of gamma-emitting radionuclides anticipated for WAG 2, the Accuspec system was deemed adequate for WAG 2 floodplain soil and sediment analyses. All samples were counted for 100 minutes.

\subsection{DATA MANAGEMENT}

Hardcopy and electronic data results from external analyses of floodplain soil and sediment samples were forwarded to the WAG 2 Analytical Services Coordinator, following the specifications of Statement of Work-118 (MMES 1993). Data were then uploaded to a Unix workstation. Hardcopy data were checked manually against the electronic data sets and differences resolved prior to analysis. Data were placed in Statistical Analysis System (SAS $\left.{ }^{\Phi}\right)$ data sets for manipulation by the task leader. Master copies of the data were maintained on the workstation.

An inventory for each radionuclide in the WAG 2 floodplain was calculated using the soil and stream sediment core data. Assuming that the samples collected within a given area were representative of that part of the floodplain, knowing the radionuclide inventory [measured in picocuries ( $\mathrm{pCi})$ ] for each core, knowing the total surface area (measured in $\mathrm{cm}^{2}$ ) sampled (the sum of surface areas for all cores) and knowing the area of the floodplain (measured in $\mathrm{m}^{2}$ ), a floodplain-wide inventory was calculated. For gamma-emitting radionuclides, three inventory 
Table 2. Listing of requested analyses for each analytical grouping from database records

\begin{tabular}{|c|c|}
\hline $\begin{array}{l}\text { Analytical } \\
\text { group }\end{array}$ & Analytes \\
\hline Gamma & ${ }^{60} \mathrm{Co},{ }^{137} \mathrm{Cs}$ \\
\hline Inorganic & $\begin{array}{l}\text { Aluminum, antimony, arsenic, barium, beryllium, boron, cadmium, } \\
\text { calcium, chromium, cobalt, copper, iron, lead, lithium, magnesium, } \\
\text { manganese, mercury, molybdenum, nickel, osmium, potassium, selenium, } \\
\text { silicon, silver, sodium, strontium, thallium, tin, vanadium, zinc }\end{array}$ \\
\hline Organic & $\begin{array}{l}\text { 1,2,4-Trichlorobenzene, 1,2-Dichlorobenzene, 1,3-Dichlorobenzene, } \\
\text { 1,4-Dichlorobenzene, 2,2'-oxybis(1-Chloropropane), } \\
\text { 2,4,5-Trichlorophenol, 2,4,6-Trichlorophenol, 2,4-Dichlorophenol, } \\
\text { 2,4-Dimethylphenol, 2,4-Dinitrophenol, 2,4-Dinitrotoluene, } \\
\text { 2,6-Dinitrotoluene, 2-Chloronaphthalene, 2-Chlorophenol, } \\
\text { 2-Methylnaphthalene, 2-Methylphenol, 2-Nitroaniline, 2-Nitrophenol, } \\
\text { 3,3'-Dichlorobenzidine, 3-Nitroaniline, 4,4'-DDD, 4,4'-DDE, 4,4'-DDT, } \\
\text { 4,6-Dinitro-2-methylphenol, 4-Bromophenyl phenyl ether, } \\
\text { 4-Bromophenyl-phenylether, 4-Chloro-3-methylphenol, 4-Chloroaniline, } \\
\text { 4-Chlorophenyl-phenylether, 4-Chlorophenylphenyl ether, } \\
\text { 4-Methylphenol, 4-Nitroaniline, 4-Nitrophenol, Acenaphthene, } \\
\text { Acenaphthylene, Aldrin, Anthracene, Aroclor-1016, Aroclor-1221, } \\
\text { Aroclor-1232, Aroclor-1242, Aroclor-1248, Aroclor-1254, Aroclor-1260, } \\
\text { Benzo(a)anthracene, Benzo(a)pyrene, Benzo(b)fluoranthene, } \\
\text { Benzo(g,h,i)perylene, Benzo(k)fluoranthene, Butyl benzyl phthalate, } \\
\text { Butylbenzylphthalate, Carbazole, Chrysene, Di-n-butyl phthalate, } \\
\text { Di-n-butylphthalate, Di-n-octyl phthalate, Di-n-octylphthalate, } \\
\text { Dibenz(a,h)anthracene, Dibenzo(a,h)anthracene, Dibenzofuran, Dieldrin, } \\
\text { Diethyl phthalate, Diethylphthalate, Dimethyl phthalate, } \\
\text { Dimethylphthalate, Endosulfan II, Endosulfan sulfate, Endosulfan-I, } \\
\text { Endrin, Endrin aldehyde, Endrin ketone, Fluoranthene, Fluorene, } \\
\text { Heptachlor, Heptachlor epoxide, Hexachlorobenzene, } \\
\text { Hexachlorobutadiene, Hexachlorocyclopentadiene, Hexachloroethane, } \\
\text { Indeno(1,2,3-cd)pyrene, Isophorone, Methoxychlor, } \\
\text { N-Nitroso-di-n-propylamine, N-Nitrosodiphenylamine, } \\
\text { N-Nitrosodiphenylamine (1), Naphthalene, Nitrobenzene, } \\
\text { Pentachlorophenol, Phenanthrene, Phenol, Pyrene, Toxaphene, alpha-BHC, } \\
\text { alpha-Chlordane, beta-BHC, bis(2-Chloroethoxy)methane, } \\
\text { bis(2-Chloroethyl)ether, bis(2-Chloroisopropyl) ether, bis(2-Ethylhexyl) } \\
\text { phthalate, bis(2-Ethylhexyl)phthalate, delta-BHC, gamma-BHC } \\
\text { (Lindane), gamma-Chlordane }\end{array}$ \\
\hline $\begin{array}{l}\text { Transuranic and } \\
\text { beta-emitting }\end{array}$ & $\begin{array}{l}{ }^{241} \mathrm{Am},{ }^{244} \mathrm{Cm},{ }^{238} \mathrm{Pu},{ }^{239240} \mathrm{Pu},{ }^{228} \mathrm{Th},{ }^{230} \mathrm{Th},{ }^{232} \mathrm{Th},{ }^{233 / 234} \mathrm{U},{ }^{235} \mathrm{U},{ }^{238} \mathrm{U} \\
{ }^{89 / 90} \mathrm{Sr},{ }^{99} \mathrm{Tc}\end{array}$ \\
\hline
\end{tabular}


values were calculated: (1) surface to $20 \mathrm{~cm}$ deep, (2) $20 \mathrm{~cm}$ to bottom of the core, and (3) whole core.

\subsection{QUALITY ASSURANCE AND QUALITY CONTROL}

Standard practices were used throughout sample collection and processing for this project, including recording in field and laboratory logbooks and chain-of-custody to assure the quality and veracity of the data presented in this report. Deviations from stated practices were recorded in the field and laboratory logbooks. Additionally, data quality objectives (DQOs) summary forms were completed to ensure that no quality issues were ignored during sample collection and processing. These forms include DQO \#001 (Flood Plain Soil, 1-15, 1993), DQO \#002 (Aquatic Floodplain Sediment Weirs, 5-16, through 6-15, 1993), DQO \#005 (Soil and Sediment Floodplain Sampling, April 26 through June 13, 1994), DQO \#006 (Soil Flood Plain Wag 5 Seep C, 4-14 and 4-18, 1994), DQO \#007 (Soil Sediment Flood Plain, Sept 14 and 19, 1994), and DQO \#008 (Soil Sediment in Intermediate Holding Pond, Oct. 5 and 10, 1994).

Throughout the WAG 2 RI, the quality of samples was controlled through the use of standard equipment decontamination and cleaning practices. The adequacy of these practices was checked through the use of field blanks, laboratory blanks, and field duplicates, at a rate of $5 \%$, or one in every twenty samples. Field duplicate samples (field homogenized sample splits) were analyzed for the relative percent difference $(R P D=$ absolute value of the differences between aliquots divided by the aliquot mean, multiplied by 100 ). The following criteria were used for RPD screening: If the ${ }^{137} \mathrm{Cs}$ activity was $>50 \mathrm{pCi} / \mathrm{g}$ and the RPD value was $>35 \%$, the sample pair was given greater scrutiny. If no quality problems were identified, then regular data ,were used for these analyses. All field duplicate and blank sample data are presented in Appendix A.

Analytical data for gamma spectrometry, determined with the Accuspec detector, were given additional scrutiny. Accuspec detectors are very sensitive to temperature fluctuations. As part of the internal laboratory QC program, daily laboratory recounts were conducted to identify gamma data runs for which the recount error was not acceptable. Complete gamma laboratory QC includes daily instrument calibration checks, routine sample recounts, and random recounts of regular samples.

\subsection{LIMITATIONS}

Samples for characterization and inventory of metal, organic, transuranic, and beta-emitting radionuclides were collected to determine (1) if co-contamination occurred and (2) any need for interim corrective measures. However, comparison of inorganic, organic, and TRU beta with gamma-emitting radionuclides for the purpose of determining co-contamination are tenuous at best because depth profile data were not collected for non-gamma contaminants. Average concentrations over the whole site may be compared; however time/episode-related determinations, based on depth incremented samples, cannot be made.

Calculations of gamma-emitting radionuclide activities for surface soil and stream sediments are made from 0 to $20 \mathrm{~cm}$ deep. This is in contrast with the 0 - to $15-\mathrm{cm}$ depth used in the human health risk exposure calculations. The depths for surface soil - stream sediment 
inventory calculations were driven by the length of the soil cores, which were sectioned in $10 \mathrm{~cm}$ increments.

Samples for gamma spectrometry, analyzed on dates for which the daily recount error was out of tolerance, or samples that were analyzed on dates with bad Accuspec QC (primarily related to drift in the gamma spectra, induced by temperature changes in the laboratory) were all reanalyzed on dates with acceptable daily recount error rates. Both acceptable and unacceptable data were uploaded to the workstation and included in the database under the same sample identification number. To correct this problem, repeated counts with differing qualifier flags were scrutinized manually because qualifier values should not change between replicate analyses. Data from unacceptable batches were excluded from further analyses. If no quality problems were identified, the first analysis date was used for all gamma data analyses.

The use of the gamma walkover data to guide core site selection was not evenly applied over WAG 2 because of shifts in technical priorities and changes in the sampling schedule due to unforeseen delays in field mobilization. All samples were collected under nominal Quality Assurance and Quality Control, and exposure of sampling personnel to ionizing radiation was kept as low as reasonably achievable (per ORNL guidelines). However, for large areas of LWOC, shown by the gamma walkover survey to have elevated contaminant levels, no soil core samples were collected (Fig. 1). Although this lack of samples may influence the gammainventory calculations that are based on core data, a direct comparison of high walkover-high core sample density with high walkover-low core sample density, testing the utility of walk over data under a variety of supporting core densities can be made. 


\section{RESULTS}

Results of these surveys and analyses are reported as gamma, TRU-beta, inorganic, and organic characterization results and gamma and inorganic inventory results. Walkover data are presented in Sect. 5. For each contaminant class listed below, the focus is on the COCs identified in the human health exposure assessment (Sect. 6) or on contaminants of general relevance and interest to the WAG 2 floodplain.

\subsection{CHARACTERIZATION}

WOC floodplain soil contaminants are dominated primarily by gamma-emitting radionuclides, ${ }^{137} \mathrm{Cs}$ [half-life $\left(t_{1 / 2}\right)=30.0$ years] and ${ }^{60} \mathrm{Co}\left(t_{1 / 2}=5.3\right.$ years $)$. Other contaminants particularly transuranics and inorganic metals, are present at levels that may be of concern. For all analytical classes, only those analytes that either contributed significantly to human health exposure (Sect. 6.2) or are particularly unique to the WAG 2 floodplain (Sect. 2) are reported. Core profile data for ${ }^{137} \mathrm{Cs}$ and ${ }^{60} \mathrm{Co}$ are summarized in Table B.1 (Appendix B) and presented graphically in Figs. C. 6 through C.22 (Appendix C). A summary of all transuranic and betaemitting radionuclides are presented in Table B.2, and inorganic analytes are summarized in Table B.3.

\subsubsection{Gamma-Emitting Radionuclides}

The primary gamma-emitting radionuclide in the WOC floodplain area was ${ }^{137} \mathrm{Cs}$, with ${ }^{60} \mathrm{Co}$ levels being $\sim 1 / 25$ or less than those of ${ }^{137} \mathrm{Cs}$ (Figs. C. 6 through C.22). No other gamma emitting radionuclides were detected during gamma-spectrometric analysis of soil or sediment core samples. For ${ }^{60} \mathrm{Co}$, the highest mean value $(194 \mathrm{pCi} / \mathrm{g})$ was found in the vicinity of the East Seep in LWOC, though greater maximum values were observed at the lower Melton Branch weir (408 $\mathrm{pCi} / \mathrm{g}$ ), in the Melton Branch floodplain (1460 pCi/g), and the upper Melton Branch weir (342 pCi/g) (Fig. 2). At these sites, ${ }^{60} \mathrm{Co}$ activity levels were significantly greater than at any other site (Table B.1). In contrast, ${ }^{137} \mathrm{Cs}$ activity levels peaked in the IHP area, particularly in the floodplain and the weir at 7500 Bridge (Fig. 3). High levels were also observed in the WOC weir region. Floodplain ${ }^{137} \mathrm{Cs}$ values were significantly $(\mathrm{p}<0.05)$ higher than at many other sites, mostly in Melton Branch and other tributaries to WOC (Table B.1).

Generally, the distribution of contamination versus depth fell into one of four patterns (Fig. 4). In the majority of cases, contamination levels were highest near the surface and decreased with depth (Fig. 4a). In a few cases, contamination levels remained high for the full extent of the core or declined only slightly near the bottom of the core (Fig. 4b), implying that a deeper core would be required to penetrate down to clean soil. In relatively clean areas the gamma values were uniformly low, as expected (Fig. 4c). In only a few cores did the concentrations start low near the surface and increase with depth, usually tailing off again at the bottom of the core (Fig. 4d). The ${ }^{137} \mathrm{Cs}$ and ${ }^{60} \mathrm{Co}$ contaminant profiles for each soil and sediment core collected for this study are found in Appendix C (Figs. C.6 through C.22). In most cores the contaminated material was close to the surface, suggesting that shielding of contaminated material by a covering of clean sediments is rare in the WAG 2 floodplain. Analysis of samples by individual core section is useful not only for gamma inventory, but also for predicting gamma emissions from soil through depth-to-peak determinations, as discussed in Sect. 5. 


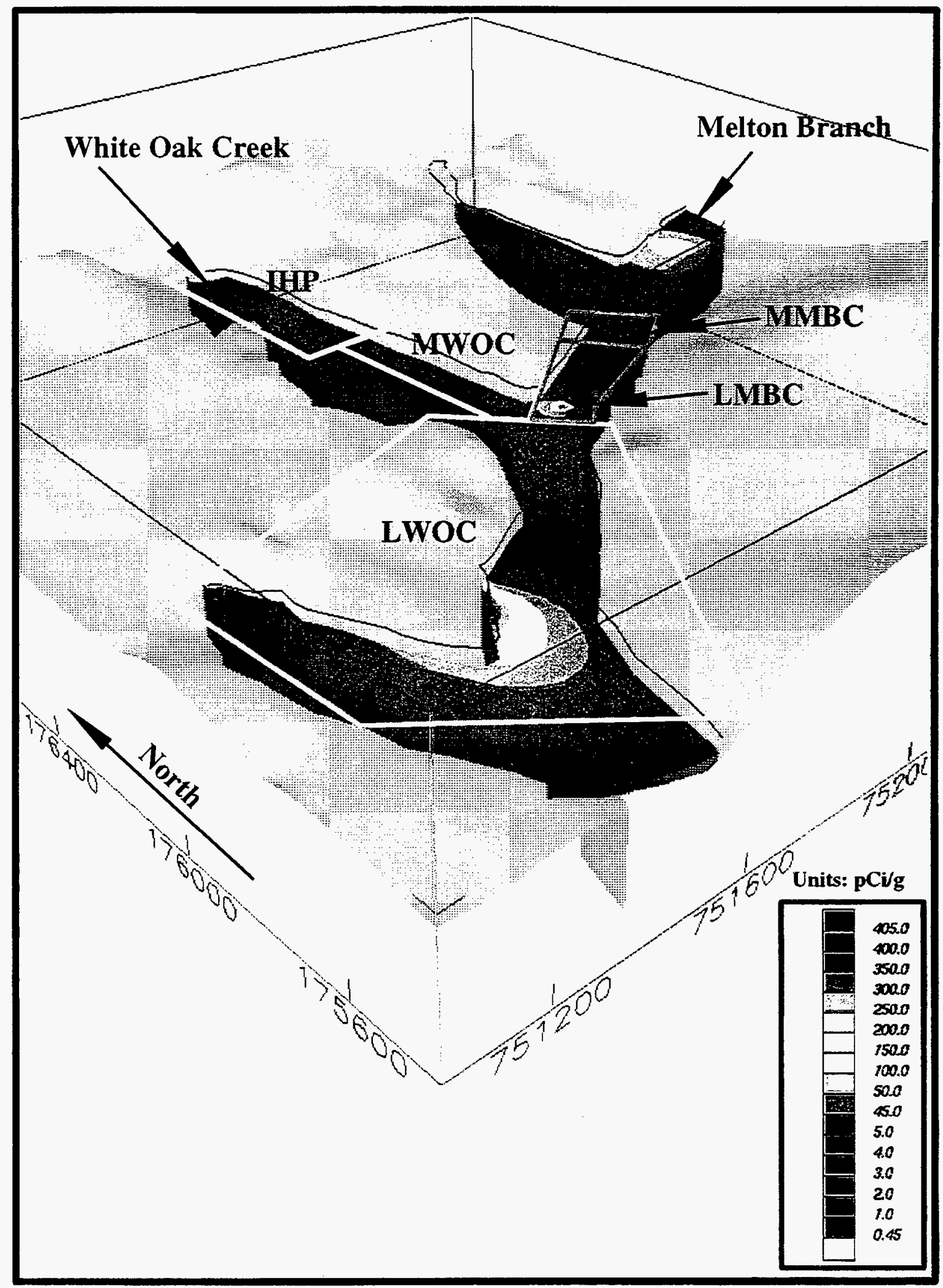

Fig. 2. Concentrations of ${ }^{60} \mathrm{Co}$ in the WAG 2 floodplain soils and sediments. 


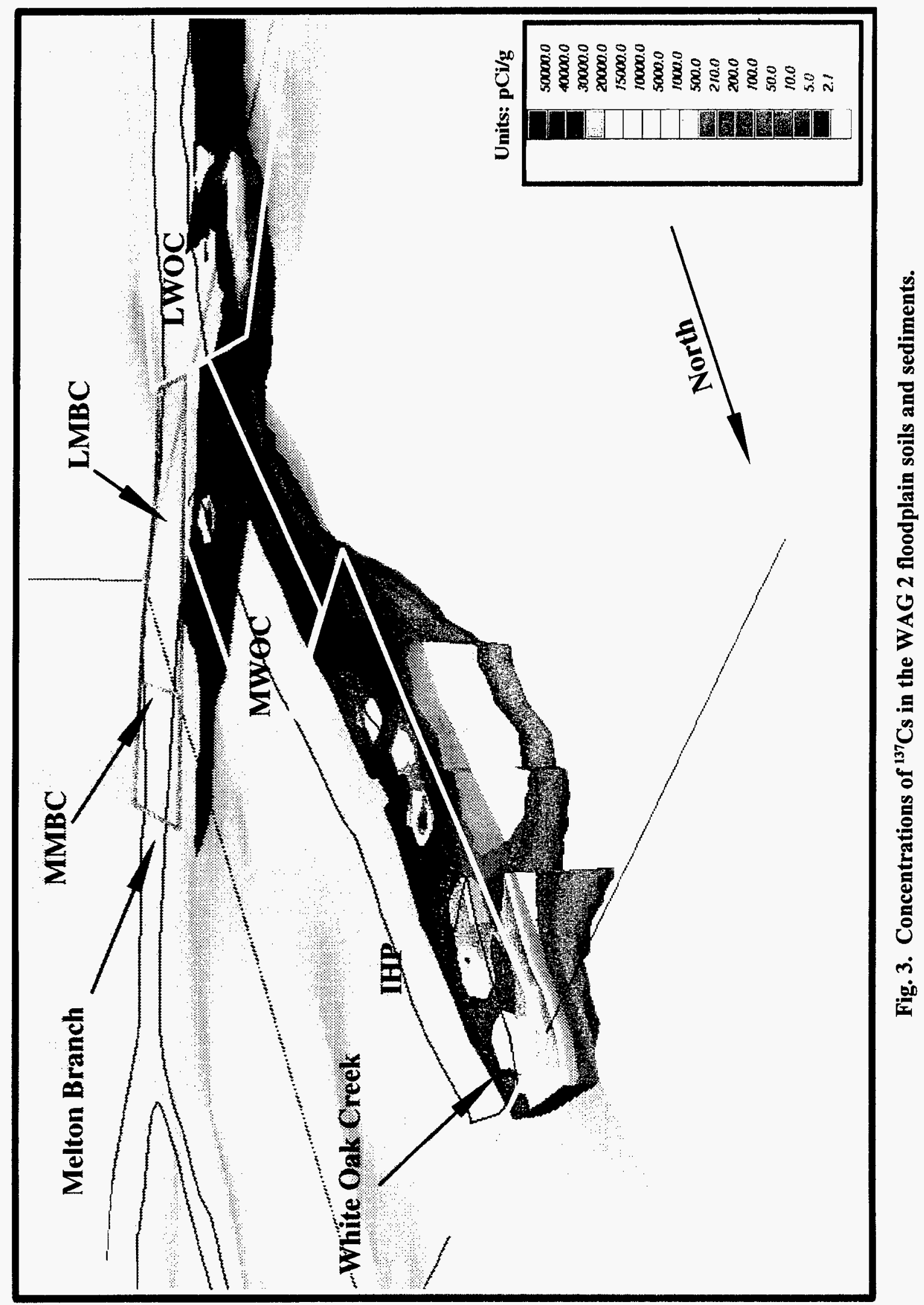



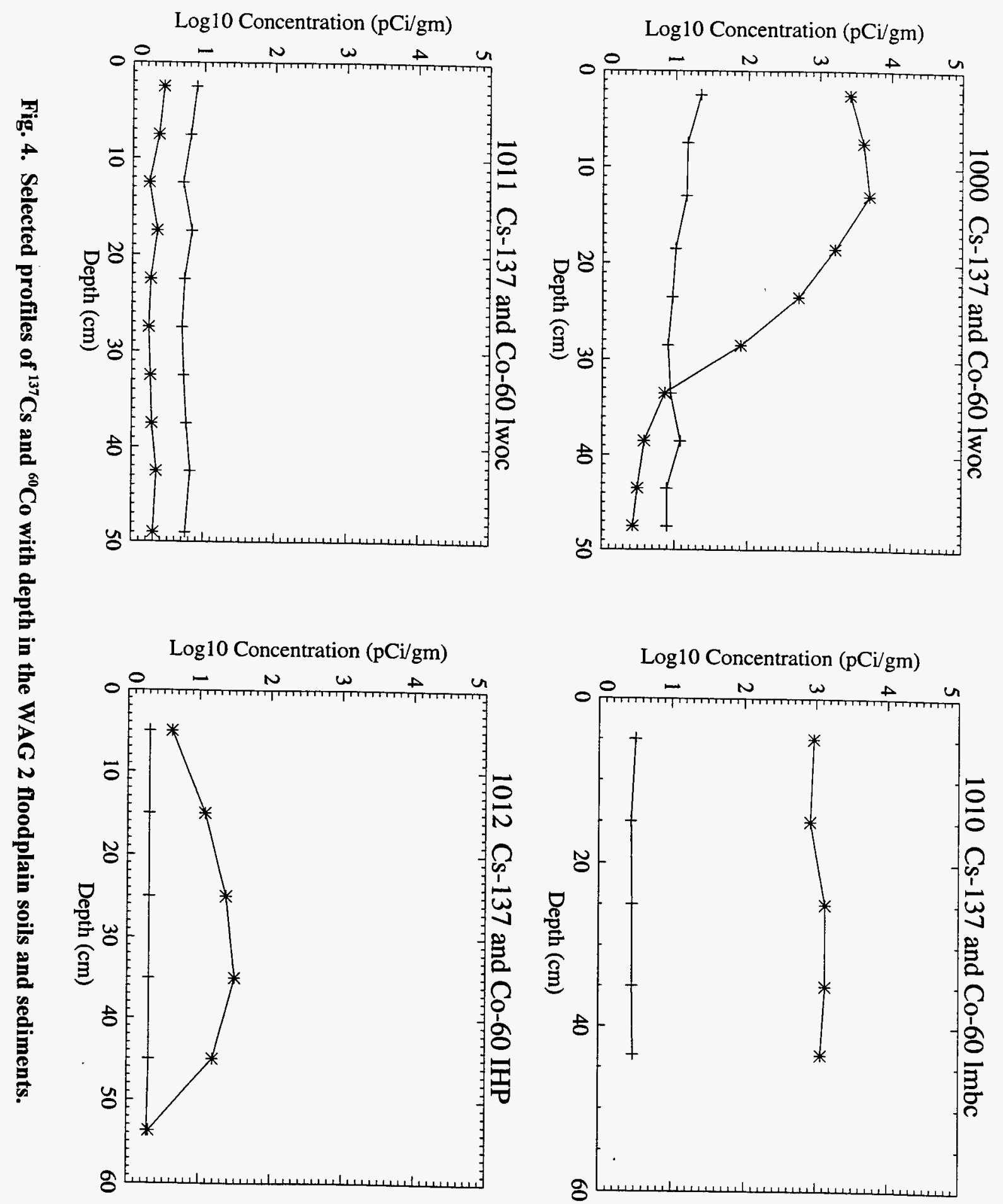


\subsubsection{Transuranic and Beta-Emitting Radionuclides}

Each of the transuranic and beta-emitting radionuclides found in WAG 2 floodplain soils and sediments is discussed below. The relative contribution of each of these radionuclides to human health risk is presented in Sect. 6. All data are presented in Table B.2. The alphaemitting radionuclides with relatively short half-lives include ${ }^{241} \mathrm{Am}\left(t_{1 / 2}=432\right.$ years $),{ }^{244} \mathrm{Cm}\left(t_{1 / 2}=\right.$ 18.1 years) and ${ }^{238} \mathrm{Pu}\left(t_{1 / 2}=87\right.$ years). In the IHP floodplain, ${ }^{241} \mathrm{Am}$ was found at its highest mean concentration ( $25 \mathrm{pCi} / \mathrm{g}$ ), with lesser amounts found in the LWOC floodplain, the WAG 4 T2A tributary and the West Seep (Table B.2). Highest mean ${ }^{244} \mathrm{Cm}$ levels were observed in the vicinity of Seep C (6.73 pCi/g), WAG 4 T2A (5.17 pCi/g), and the IHP floodplain. For ${ }^{238} \mathrm{Pu}$, largest mean values are seen in the IHP floodplain $(2.8 \mathrm{pCi} / \mathrm{g})$ and lower Melton Branch weir $(2.24 \mathrm{pCi} / \mathrm{g})$. For each of these radionuclides, the relative contribution of each site relative to mean concentrations are presented in Fig. 5; no significant differences in mean concentration were found between these sites.

Mean, maximum and minimum concentration values for the remaining alpha-emitting radionuclides with exceedingly long half-lives - ${ }^{239 / 240} \mathrm{Pu}\left(t_{1 /} 6.54 \times 10^{3}\right.$ years for ${ }^{239} \mathrm{Pu}$ and $2.41 \times 10^{4}$ years for $\left.{ }^{240} \mathrm{Pu}\right),{ }^{228} \mathrm{Th},{ }^{230} \mathrm{Th}\left(t_{/ / 2}=7.7 \times 10^{4}\right.$ years $),{ }^{232} \mathrm{Th}\left(t_{1 / 2}=1.41 \times 10^{10}\right.$ years $)$, ${ }^{233 / 234} \mathrm{U}\left(t_{1 / 2}=2.44 \times 10^{5}\right.$ years $),{ }^{235} \mathrm{U}\left(t_{1 / 2}=7.04 \times 10^{8}\right.$ years $)$ and ${ }^{238} \mathrm{U}\left(t_{1 / 2}=4.49 \times 10^{9}\right.$ years $)$-are listed in Table B.2; the relative contribution of mean values from each site relative to the total for all sites is presented in Fig. 6. Mean ${ }^{239 / 240} \mathrm{Pu}$ values peaked in the IHP floodplain (59.3 pCi/g), with notable levels in the West Seep (37.5 pCi/g); neither of these was significantly greater than mean values from other sites (Table B.2). Mean ${ }^{230} \mathrm{Th}$ and ${ }^{232} \mathrm{Th}$ isotope levels peaked primarily in the IHP floodplain (20.61 pCi $\left./ \mathrm{g}^{230} \mathrm{Th}\right)$, the Melton Branch floodplain $\left(6.54 \mathrm{pCi} / \mathrm{g}{ }^{230} \mathrm{Th}\right.$ ), and the MWOC floodplain (5.42 pCi/g ${ }^{230} \mathrm{Th}$ ), with IHP floodplain values for ${ }^{230} \mathrm{Th}$ significantly greater that for other sites. However, ${ }^{228}$ Th peak values were observed at the West Seep to LWOC $(5.85 \mathrm{pCi} / \mathrm{g})$ and in the lower floodplain of WOC $(4.28 \mathrm{pCi} / \mathrm{g})$, as well as the IHP floodplain (6.45 pCi/g) (Fig. 6). Mean ${ }^{235} U$ and ${ }^{238} U$ isotope levels peaked in the IHP floodplain ( 5.45 and $11.7 \mathrm{pCi} / \mathrm{g}$, respectively), with the mean ${ }^{238} \mathrm{U}$ being significantly greater than for other sites (Table B.2). Also ${ }^{233234} \mathrm{U}$ mean levels were significantly highest in the West Seep (55.5 $\mathrm{pCi} / \mathrm{g}$ ), suggesting alternate sources or fates for these isotopes (Fig. 6, Table B.2). ${ }^{233 / 234} \mathrm{U}$ mean levels were significantly higher in the West Seep $(55.5 \mathrm{pCi} / \mathrm{g})$, suggesting alternate sources or fates for these isotopes (Fig. 6, Table B.2).

Total radioactive strontium, which consists of both ${ }^{89} \mathrm{Sr}$ and ${ }^{90} \mathrm{Sr}\left(t_{1 / 2}=29.1\right.$ years $)$, and ${ }^{99} \mathrm{Tc}$ $\left(t_{1 / 2}=2.13 \times 10^{5}\right.$ years $)$ are the beta-emitting radionuclides found in WAG 2. Seep C accounted for $98 \%$ of all ${ }^{89190} \mathrm{Sr}$ measured in WAG 2 , a statistically significant proportion

(Fig. 5, Table B.2). In contrast, ${ }^{99} \mathrm{Tc}$ was mostly found in the LWOC floodplain (mean: 109 $\mathrm{pCi} / \mathrm{g}$ ) and the West Seep (mean: $146 \mathrm{pCi} / \mathrm{g}$ ) (see Fig. 5 and Table B.2).

\subsubsection{Inorganics}

Results for inorganic contaminants in the WOC and Melton Branch soil and sediments are limited to those contributing significantly to human health risk, either as carcinogens or noncarcinogens (Sect. 6). Those contaminants throughout the watershed that contribute $>10 \%$ to an overall risk pathway include $\mathrm{Sb}, \mathrm{Ba}, \mathrm{Cr}$ [total $\mathrm{Cr}$ conservatively presumed to be $\mathrm{Cr}(\mathrm{IV})$ for human health risk], $\mathrm{Mn}, \mathrm{Hg}$, and Ni. All data are found in Table B.3. 


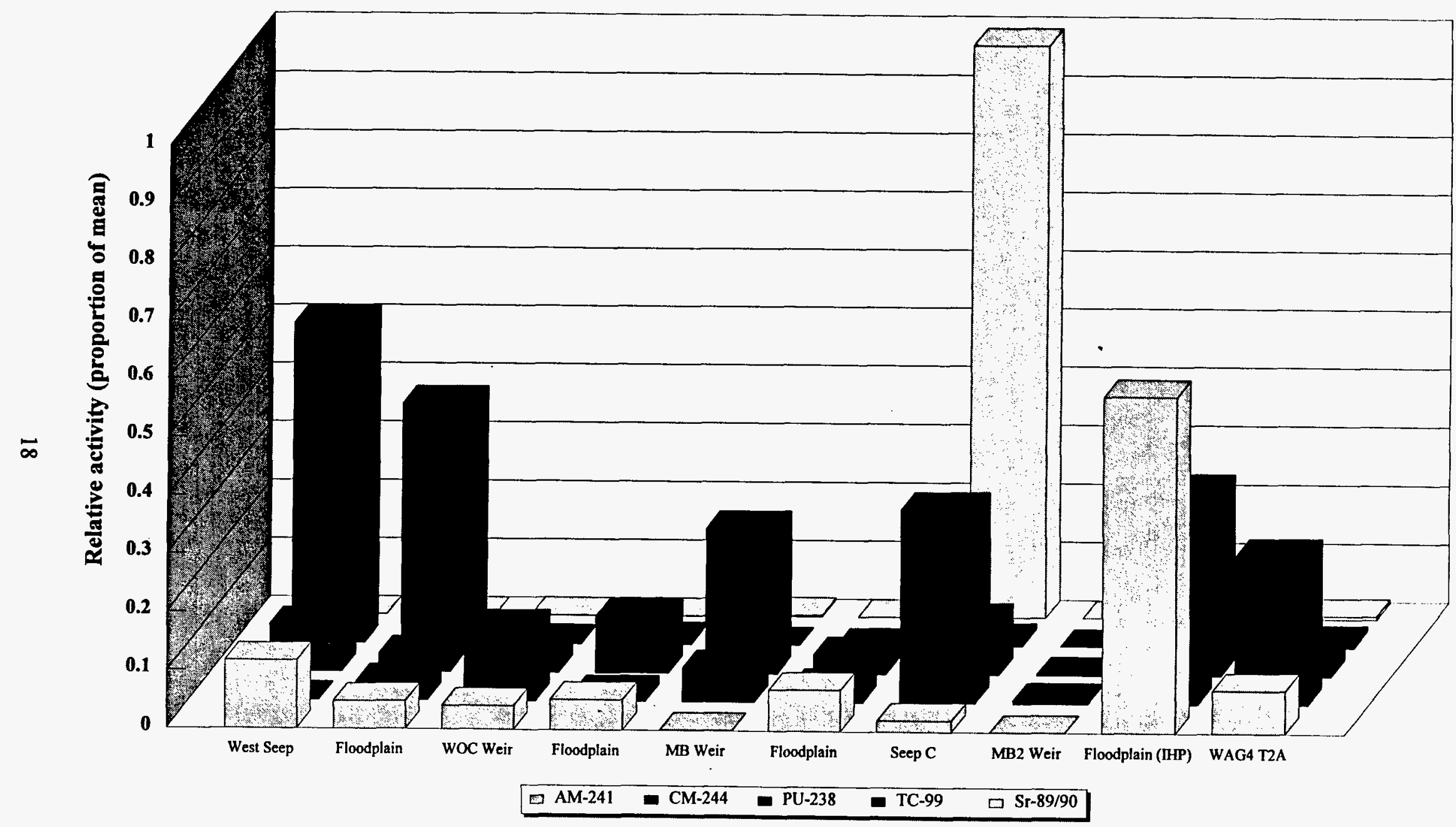

Fig. 5. Relative proportions calculated from mean of selected alpha- and beta-emitting radionuclides in WAG 2 floodplain soils and sediments. 


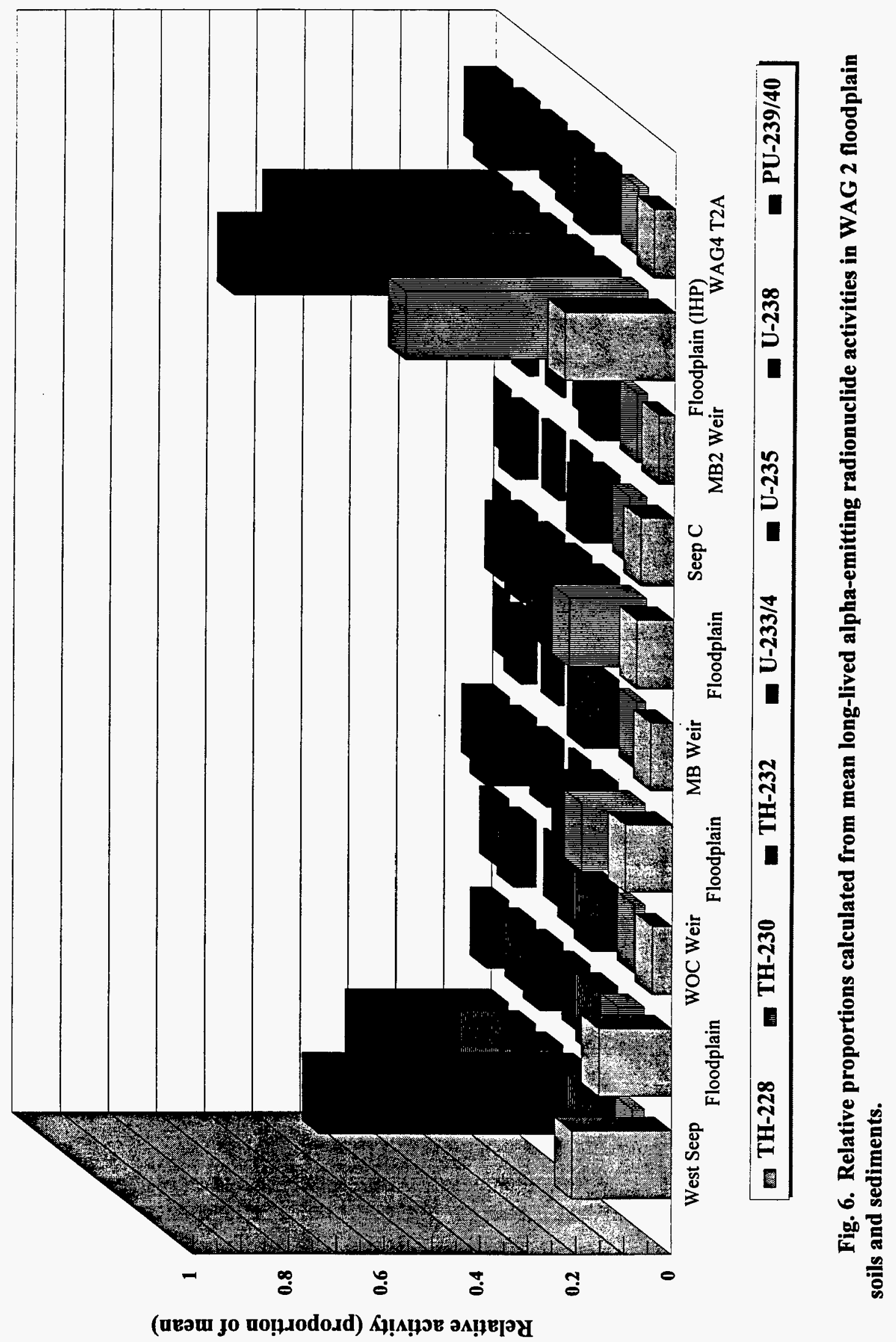


Highest $\mathrm{Sb}$ values were generally associated with floodplain soils across all areas. Mean values for floodplain samples ranged from $6.9 \mathrm{mg} / \mathrm{kg}$ in LWOC to $14.1 \mathrm{mg} / \mathrm{kg}$ in the IHP, whereas seep and weir values varied little $(0.5$ to $1.3 \mathrm{mg} / \mathrm{kg}$ ) excluding Seep C (Fig. 7). Mean floodplain values were significantly greater $(p<0.05)$ than seep or weir values across all reaches (Table B.3). Values for Seep C reflect areas more characteristic of floodplain soils than seeps. There are no documented sources for $\mathrm{Sb}$ to the WAG 2 floodplain. The highest mean $\mathrm{Ba}$ values were generally seen in the Melton Branch watershed area, with peak values at the upper Melton Branch weir, declining downstream through the Seep C area. Outside of Melton Branch, Ba values fell into a relatively narrow range (74-268, Table B.3).

Analysis of $\mathrm{Cr}(\mathrm{IV})$ data indicates values in Melton Branch weirs (55 to $168 \mathrm{mg} / \mathrm{kg}$ ) were significantly higher than other sites in WAG 2; values at the remaining sites fell into a narrower range (15 to $70 \mathrm{mg} / \mathrm{kg}$ ). Additionally, maximum values in the IHP (30 to $70 \mathrm{mg} / \mathrm{kg}$ ) and LWOC floodplain ( 2 to $95 \mathrm{mg} / \mathrm{kg}$ ) were higher than observed elsewhere in the WOC drainage. Results suggest sources for $\mathrm{Cr}$ (IV) further upstream in WAG 2, primarily in Melton Branch but also in WOC. Table B. 3 and Fig. 8 summarize these data.

Manganese, a natural component of soils, was significantly greater in upper Melton Branch and Seep C than in any other reach (Table B.3), a reflection of natural differences between the two watersheds. These values are within the range observed for both contaminated and uncontaminated sites in the vicinity of the ORR (Kornegay et al., 1994). Concentrations of $\mathrm{Hg}$ were the highest in the IHP floodplain, with mean values between 7 and 20 times higher than other areas, though there were no significant differences between locations (Table B.3, Fig. 9). Mercury levels in WAG 2 were similar to those observed at contaminated sites on the ORR (Kornegay et al., 1994). Patterns of Ni contamination are similar to those of $\mathrm{Hg}$, being highest in the IHP area (Table B.3, Fig. 10). As with $\mathrm{Hg}$, no significant differences between sites were observed. Values in the WOC and Melton Branch floodplain soils were within the range of those values measured for noncontaminated sites on the ORR (Kornegay et al., 1994).

\subsubsection{Organics}

Only the organic chemicals identified through human health risk evaluation (Sect. 6) as contributing to risk are discussed here. These include aroclor-1254, aroclor-1260, benzo(a)pyrene, dibenz(a,h)anthracene, and benzo(a)anthracene. Though many samples were collected (Table 1), the vast majority of organic analytes were undetected. In the IHP, aroclor1254, aroclor-1260, benzo(a)pyrene, and dibenz(a,h)anthracene were detected. Organic contaminants in MWOC include aroclor-1260, benzo(a)pyrene, benzo(a)anthracene and dibenz(a,h)anthracene. LWOC organic contaminants included aroclor-1260, benzo(a)pyrene and benzo(a)anthracene. Further discussion of these contaminants is found in Sect. 6.

\subsection{INVENTORY}

Inventory values for gamma-emitting radionuclides based on sediment core profiles are the most complete of all data. For alpha- and beta-emitting radionuclides, and inorganic and organic contaminants, inventory values are qualitative because of sample collection limitations. Assuming that processes of deposition and erosion act similarly on all particle-associated contaminants, differences in mean contaminants within each reach may be attributed to differences in sources. Gamma inventory data are presented in Sect. 4.2.1. 


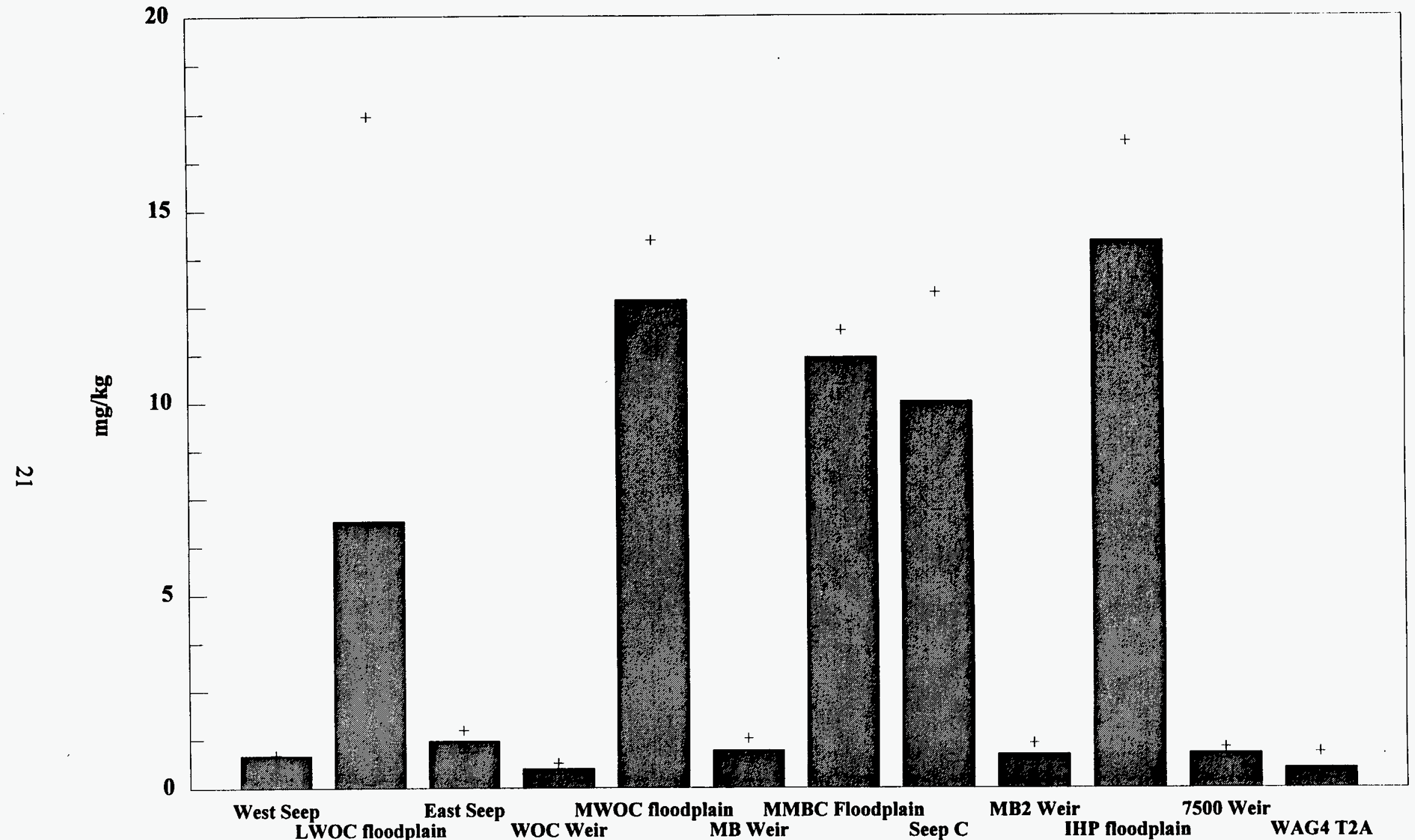

Fig. 7. Mean antimony concentrations \pm 1 SD in WAG 2 floodplain soils and sediments. 


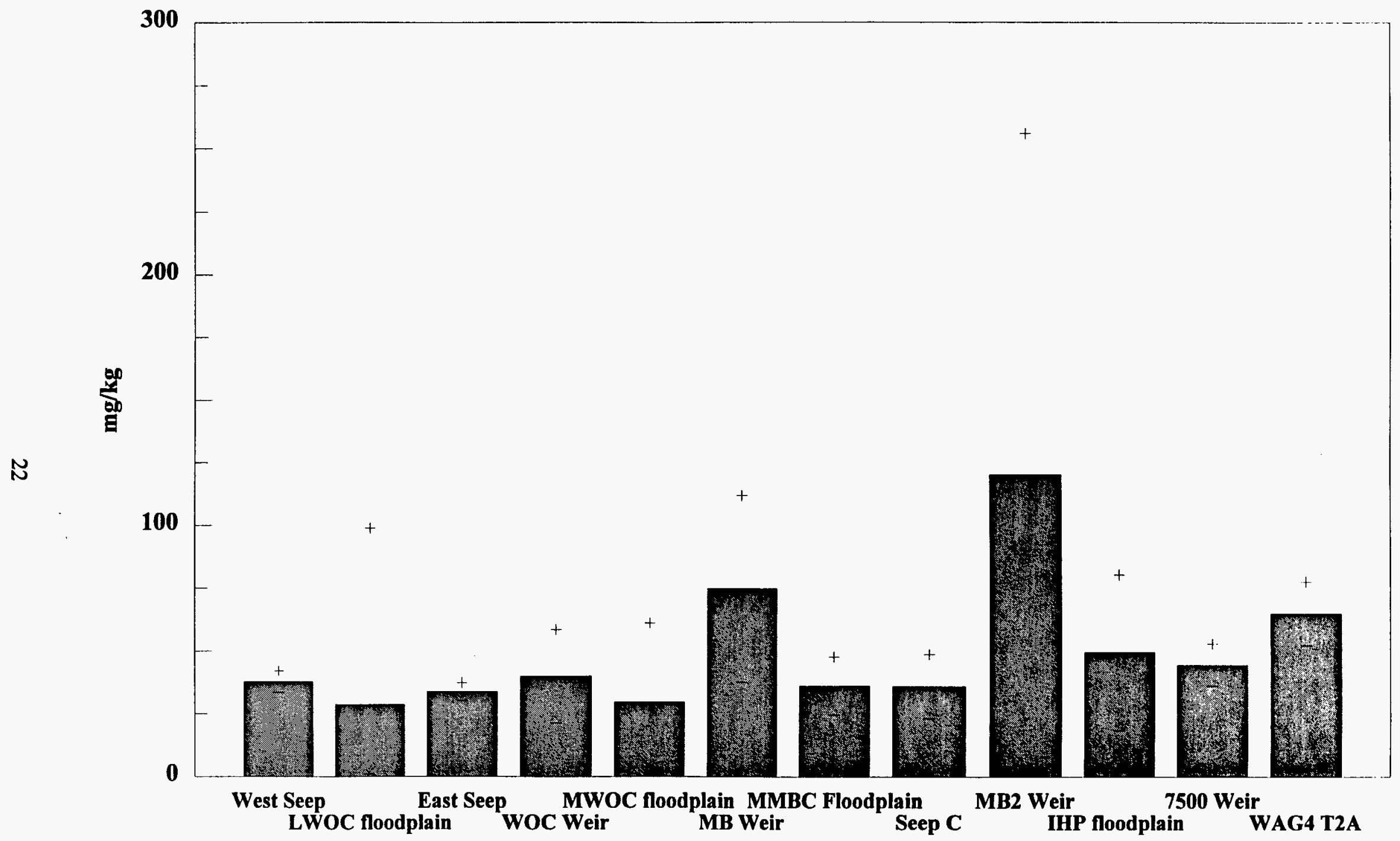

Fig. 8. Mean chromium concentrations \pm 1 SD in WAG 2 floodplain soils and sediments. 


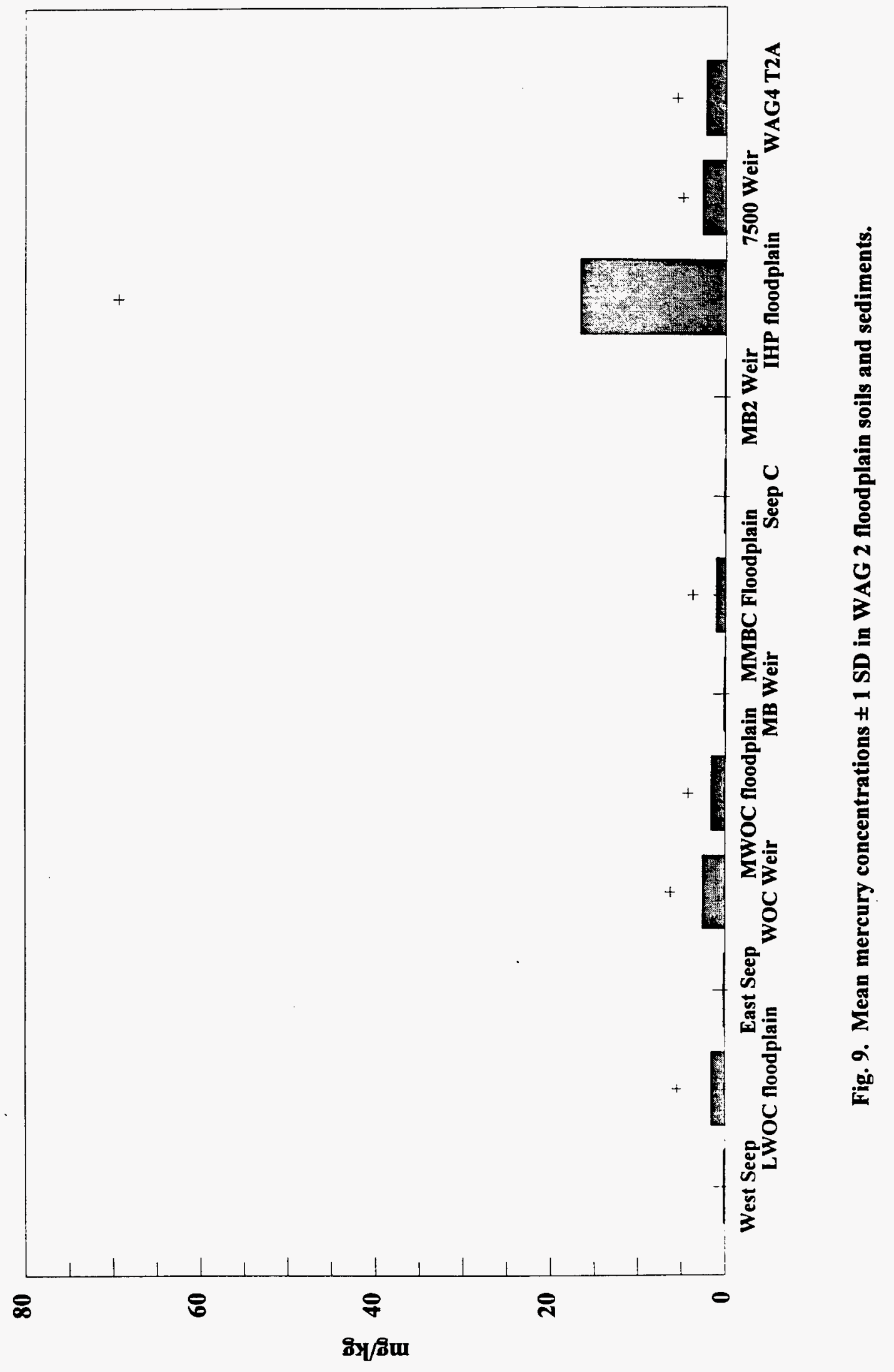




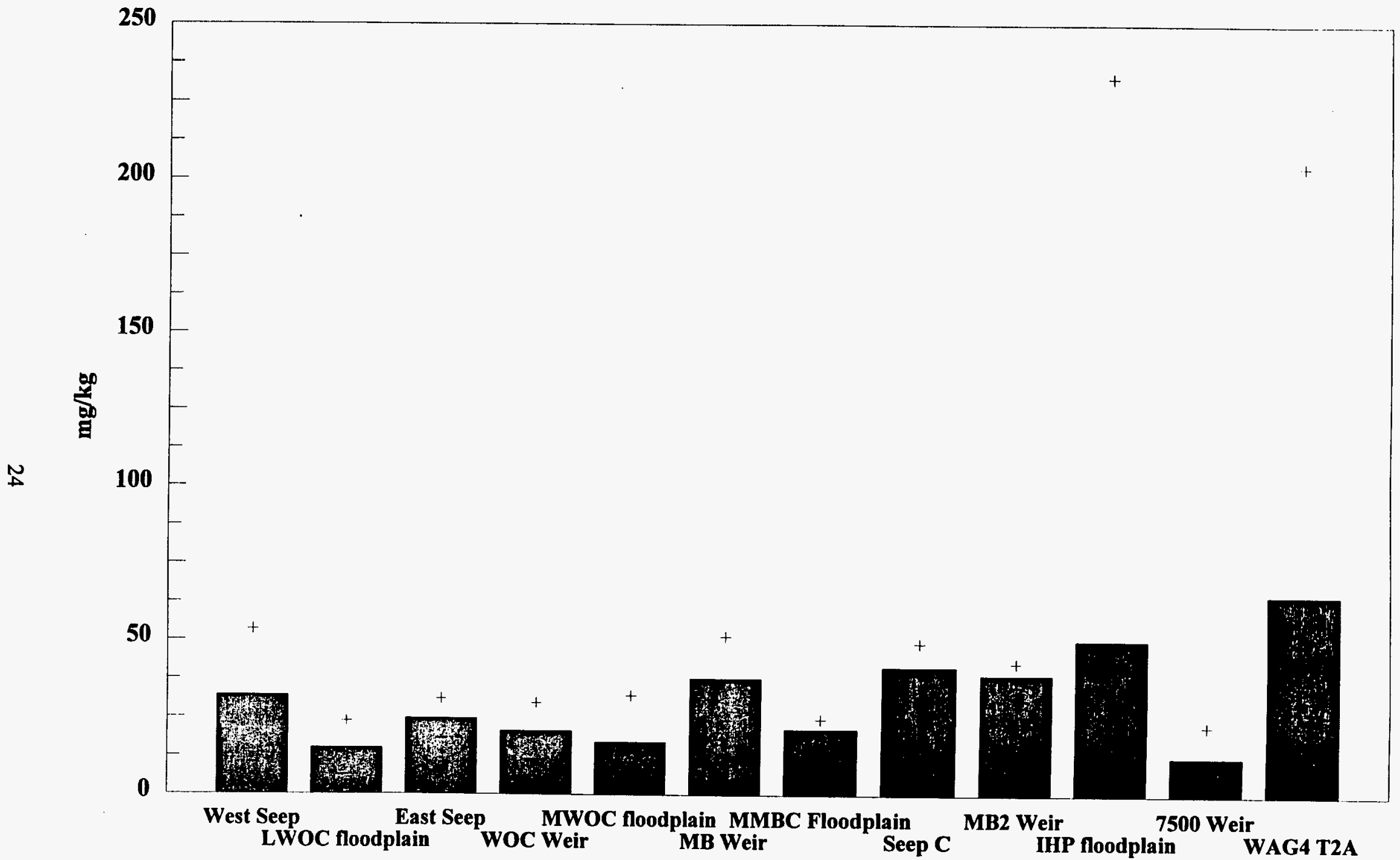

Fig. 10. Mean nickel concentrations \pm 1 SD in WAG 2 floodplain soils and sediments. 
Conjecture and discussion of the inventory of inorganic contaminants in floodplain soils is presented on a limited basis. Estimates of organic inventories are not presented, but they can be presumed to behave similarly.

\subsubsection{Gamma Inventory}

The gamma inventory is based on the sediment core samples. Although cores were to be collected based on walkover data from across WAG 2 (see Sect. 3.7), a disproportionate number were collected from the IHP area (Fig. 1) relative to the contamination pattern indicated by the walkover survey (Sect. 5.2) and the collection frequency specified in Sect. 3.2. As noted in Section 3.5 , inventory values were estimated by calculating individual core inventories, then using the ratio of core surface to study area surface, calculating an inventory for the entire study area.

Computer visualization methods provide informative graphics showing the general distributions of gamma-emitting contaminants (Figs. 11, 12). Inventory estimates based on visualization techniques were very low, probably due to the sampling density. The method does not account for WAG 2 areas with low sampling density.

4.2.1.1 Ratio technique. Inventory values for gamma-emitting radionuclides for each core section $\left(I_{S}\right)$ were estimated by multiplying the concentration $(C)$ in $\mathrm{pCi} / \mathrm{g}$ by soil density $(\mathrm{p}, 1.6$ $\left.\mathrm{g} / \mathrm{cm}^{3}\right)$, core surface area $\left(a_{C}, 2.83 \mathrm{~cm}^{2}\right.$ for soil cores or $13.38 \mathrm{~cm}^{2}$ for sediment cores) and the length $(l)$ of the core section (measured in centimeters) to yield pCi in each section (Equation 1 ). The inventory for each section was then summed for a given core $\left(I_{C}\right.$, Equation 2$)$ and for all cores within a reach to give inventory for all cores in each reach $\left(I_{C R}\right.$, Equation 3$)$. The total inventory $\left(I_{R}\right)$ for each reach was then estimated by multiplying the inventory for all cores in the reach by the whole surface area of the reach $\left(A_{R}\right)$ (given in Table 1 ), then dividing the result by the surface area of all cores $\left(A_{C}\right)$ sampled (Equation 4$)$.

$$
\begin{aligned}
& I_{S}=C \times \boldsymbol{\rho} \times l \times a_{C} \\
& I_{C}=\boldsymbol{\Sigma} I_{S} \\
& I_{C R}=\boldsymbol{\Sigma} I_{C} \\
& I_{R}=\left(I_{C R} \times A_{R}\right) / A_{C}
\end{aligned}
$$

This series of equations was performed for both the surface-to-20-cm sections and those deeper than $20 \mathrm{~cm}$.

4.2.1.2 Results of ratio technique. A total of $2.2 \mathrm{Ci}$ of ${ }^{60} \mathrm{Co}$ was estimated for WAG 2 (Table 3). Most ${ }^{60} \mathrm{Co}$ was observed in LWOC followed by the IHP and LMBC. Surface soil and stream sediments $\left(0-20 \mathrm{~cm}\right.$ deep) contained $40 \%$ of the ${ }^{60} \mathrm{Co}$ in LWOC, $43 \%$ in IHP and only $21 \%$ in LMBC. The inventory of ${ }^{60} \mathrm{Co}(33,000 \mathrm{pCi})$ observed in the UMBC core was the fourth largest observed for individual cores in the WAG 2 floodplain. Inventory estimates were not calculated for areas with only one core sample.

A considerably higher inventory of ${ }^{137} \mathrm{Cs}(198.6 \mathrm{Ci})$ was estimated for the WAG 2 floodplain soils and sediments (Table 3 ), with the vast majority predicted for the IHP (125 Ci) 


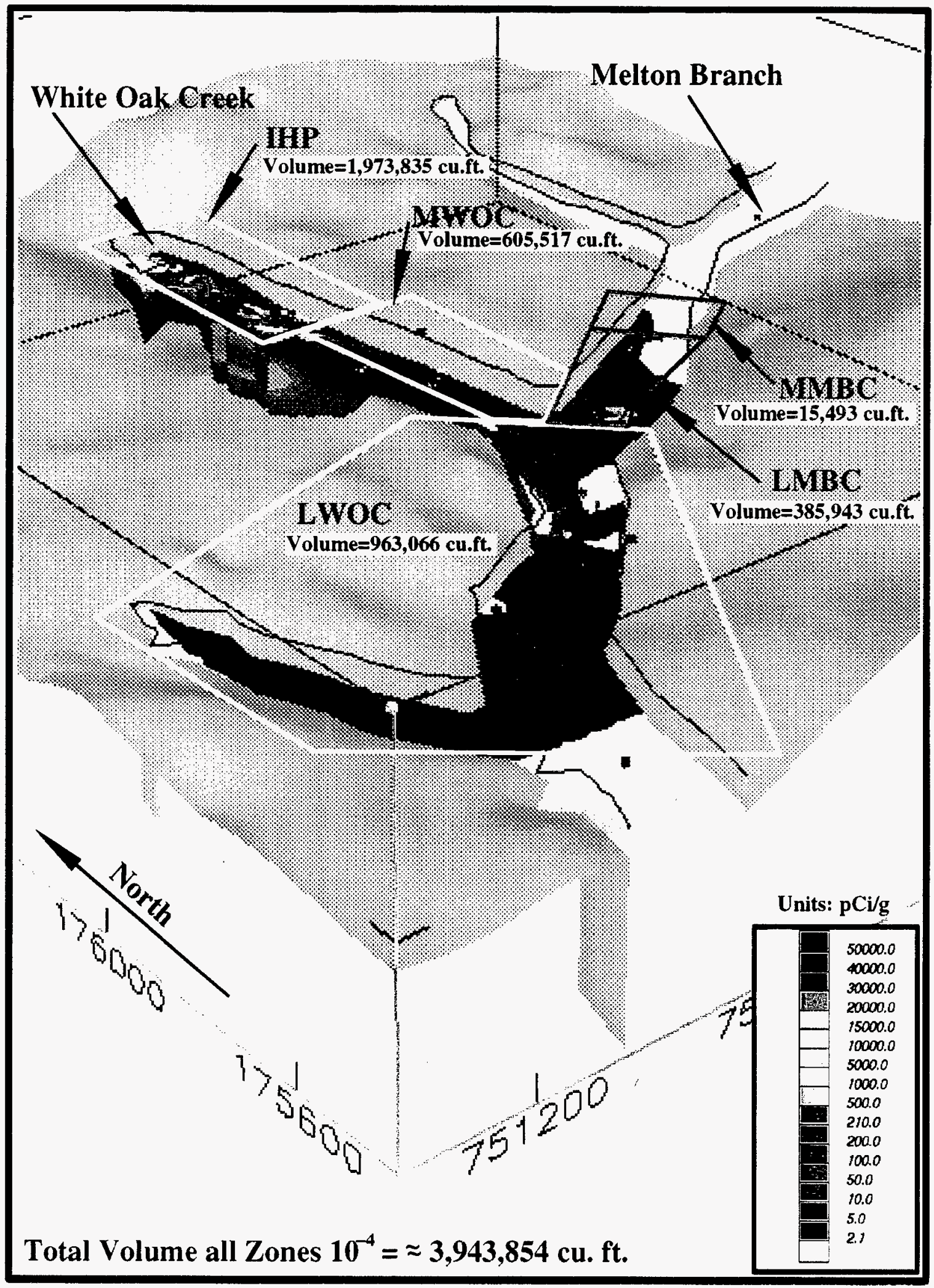

Fig. 11. Inventory of ${ }^{137} \mathrm{Cs}$ corresponding to a $10^{-4}$ human health risk. 


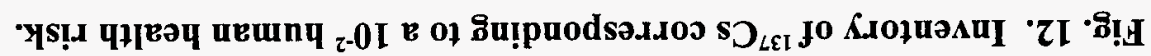

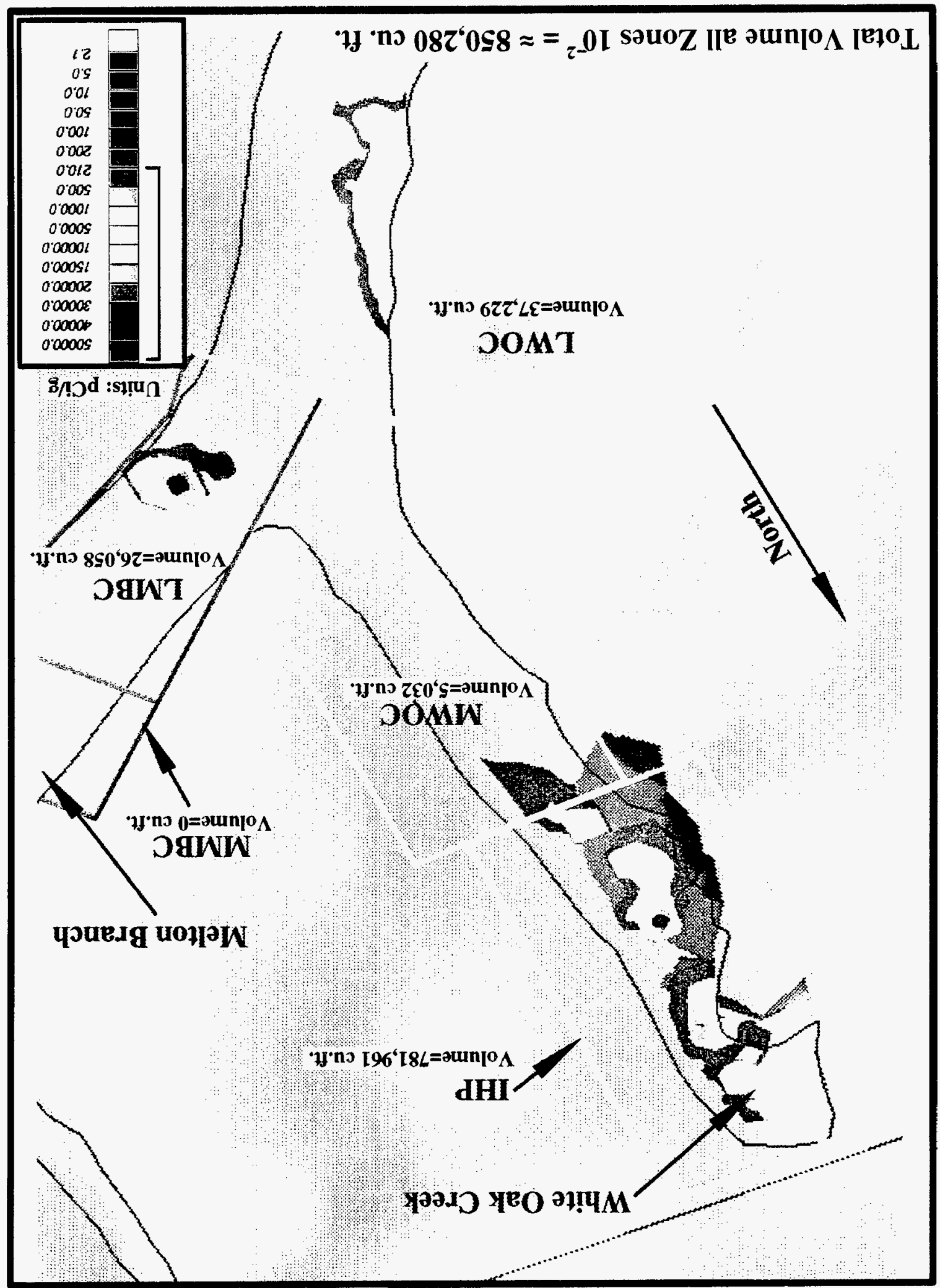


Table 3. Gamma-emitting radionuclide inventory estimates based on ratios from soil and sediment cores in the WAG 2 floodplain

\begin{tabular}{|c|c|c|c|c|}
\hline \multirow[b]{2}{*}{ Area $^{a}$} & \multirow[b]{2}{*}{$\begin{array}{c}\text { Number of } \\
\text { cores }\end{array}$} & \multicolumn{3}{|c|}{ Inventory (curies) } \\
\hline & & $\begin{array}{l}\text { Surface to } \\
<20 \mathrm{~cm}\end{array}$ & $20 \mathrm{~cm}$ to bottom & Total \\
\hline \multicolumn{5}{|c|}{ Cobalt-60 } \\
\hline IHP & 39 & 0.1429 & 0.1822 & 0.3251 \\
\hline MWOC & 17 & 0.0086 & 0.0099 & 0.0185 \\
\hline LWOC & 23 & 0.7329 & 1.0805 & 1.8134 \\
\hline $\mathrm{UMBC}^{b}$ & 1 & - & - & - \\
\hline $\mathrm{MMBC}$ & 6 & 0.0014 & 0.0010 & 0.0024 \\
\hline LMBC & 12 & 0.0131 & 0.0492 & 0.0623 \\
\hline Total & & 0.8989 & 1.3228 & 2.2217 \\
\hline \multicolumn{5}{|c|}{ Cesium-137 } \\
\hline IHP & 39 & 53.5819 & 71.6645 & 125.2464 \\
\hline MWOC & 17 & 0.9182 & 0.1870 & 1.1052 \\
\hline LWOC & 23 & 32.0852 & 38.5706 & 70.6558 \\
\hline $\mathrm{UMBC}^{b}$ & 1 & - & - & - \\
\hline $\mathrm{MMBC}$ & 6 & 0.0045 & 0.0005 & 0.0050 \\
\hline LMBC & 12 & 0.8059 & 0.8290 & 1.6349 \\
\hline Total & & 87.3957 & 111.2516 & 198.6473 \\
\hline
\end{tabular}

a $\mathrm{IHP}=$ Intermediate Holding Pond; LMBC $=$ Lower Melton Branch Creek; LWOC $=$ Lower White Oak Creek; $\mathrm{MMBC}=$ Middle Melton Branch Creek; $\mathrm{MWOC}=$ Middle White Oak Creek; UMBC $=$ Upper Melton Branch Creek.

${ }^{b}$ Because of the small number of observations for UMBC, inventory values were not calculated. 
and LWOC $(70 \mathrm{Ci})$ reaches. Within these two reaches, 42 and $45 \%$ respectively of the inventory was expected in the surface layer (to $20 \mathrm{~cm}$ ). However, the inventory calculated for the MWOC reach, that part of WAG 2 between the IHP and LWOC, was much smaller $(1.1 \mathrm{Ci})$, with $82 \%$ observed in the surface layer. Of the Melton Branch reaches, the LMBC inventory of $1.6 \mathrm{Ci}$ was greatest, with $49 \%$ observed in the surface layer.

The applicability of the ratio technique maybe questioned on several fronts. The ratio technique is sensitive to the sample density and representativeness per given area. For example, the WAG 2 floodplain, the IHP ( $\sim 5$ cores per ha) and LWOC ( $\sim 2.6$ cores per hectare) had very different core densities. Comparing the ${ }^{137} \mathrm{Cs}$ inventory estimates for the IHP with historic data compiled by A. Brenkert (Table B.4), the present data yield a ${ }^{137} \mathrm{Cs}$ inventory approximately twice as high as that calculated by Dahlman and Van Voris (1976), decay corrected to 1995. Sample sites in the IHP were biased toward "hot spots", with the possible result being that the inventory from the ratio technique was an overestimate. Though comparable historic estimates for LWOC were not available, qualitative comparison of floodplain inventories in Table 3 with observed USRADS data (Fig. 13), indicates that for LWOC, several "hot spots" were not sampled. The same mechanism in the ratio technique that overestimates previously reported inventories in the IHP ( $\sim 45$ cores per ha), should vastly underestimate the inventory in LWOC $(\sim 2.6$ cores per ha). Overall, the ratio technique applied to the WAG 2 floodplain may provide a very reasonable estimate of ${ }^{137} \mathrm{Cs}$ inventory, given the historic ranges (Clapp et al. 1995). These issues are discussed in detail in Sect. 5.

Inventory values for the transuranic and beta-emitting radionuclides were estimated for each core in much the same manner as for gamma-emitting radionuclides, by multiplying the concentration in $\mathrm{pCi} / \mathrm{g}$ by soil density $\left(1.6 \mathrm{~g} / \mathrm{cm}^{3}\right)$, sample surface area $\left(2.83 \mathrm{~cm}^{2}\right.$ for soil cores, or $13.38 \mathrm{~cm}^{2}$ for sediment cores) and the length of the core $(\mathrm{cm})$ to yield $\mathrm{pCi}$ in each core (Equation 1). Data for individual sections within a given core were not collected for transuranic and beta-emitting radionuclides; therefore Equation 2 was not used for these analytes. Activities of all cores for a given reach were then summed (Equation 3). The total inventory for each reach was then estimated by multiplying the inventory for all cores in a given reach by the whole surface area of the reach, then dividing by the surface area of the cores sampled (Equation 4).

Inventory values were lowest in MMBC and highest in $\mathrm{LWOC}$ for ${ }^{241} \mathrm{Am},{ }^{244} \mathrm{Cm},{ }^{238} \mathrm{Pu}$, ${ }^{239 / 240} \mathrm{Pu},{ }^{99} \mathrm{Tc},{ }^{228} \mathrm{Th},{ }^{230} \mathrm{Th},{ }^{233 / 234} \mathrm{U}$, and ${ }^{238} \mathrm{U}$ (Table 4). The inventory for ${ }^{89 / 90} \mathrm{Sr}$ was lowest in MWOC, but highest in MMBC, corresponding with the elevated levels detected at Seep C. Values for ${ }^{235} \mathrm{U}$ were lowest in $\mathrm{MMBC}$, but highest in the IHP. Inventories were not calculated for either LMBC or UMBC due to the small $(n=1)$ sample size.

\subsubsection{Inorganic Inventory}

No inventories were calculated for metals. Qualitatively, the largest inventories are expected where concentrations are the greatest. Highest Antimony inventories should be found in the floodplain areas for each reach, with smaller amounts expected for weir sediments and most seeps. Antimony may not be particle-associated under conditions observed at least seasonally near the weirs and seeps, leading to movement of Antimony out of areas that are subject to inundation from local creeks or springs. Barium inventories should be up to eight times higher in Melton Branch, near the upper weir, than for other locations in WAG 2. Barium levels in other reaches are within the range observed for clean ORR soils (Kornegay et al. 1994). 
Table 4. Transuranic radionuclide inventory estimates based on ratios from soil and sediment cores in the WAG 2 floodplain

\begin{tabular}{|c|c|c|c|c|c|}
\hline \multirow[t]{2}{*}{ Area $^{a}$} & \multirow[t]{2}{*}{$\begin{array}{l}\text { Number } \\
\text { of cores }\end{array}$} & \multicolumn{4}{|c|}{ Total inventory $(\mathrm{C} i)$ based on ratios } \\
\hline & & $A m-241$ & $C m-244$ & $P u-238$ & $P u-239 / 240$ \\
\hline IHP & 7 & $4.75 \mathrm{E}-02$ & $4.50 \mathrm{E}-03$ & $5.59 \mathrm{E}-03$ & $1.07 \mathrm{E}-01$ \\
\hline $\mathrm{LMBC}^{b}$ & 1 & - & - & - & - \\
\hline LWOC & 5 & $6.97 \mathrm{E}-02$ & $1.25 \mathrm{E}-02$ & $7.06 \mathrm{E}-03$ & 2.07E-01 \\
\hline MMBC & 3 & $6.48 \mathrm{E}-04$ & $2.09 \mathrm{E}-04$ & $7.27 \mathrm{E}-05$ & $6.30 \mathrm{E}-05$ \\
\hline MWOC & 3 & $1.95 \mathrm{E}-03$ & $6.15 \mathrm{E}-04$ & $6.15 \mathrm{E}-04$ & $5.35 \mathrm{E}-03$ \\
\hline $\mathrm{UMBC}^{b}$ & 1 & - & - & - & - \\
\hline \multirow[t]{2}{*}{ Total } & & 2.02E-01 & $1.40 \mathrm{E}-01$ & $1.33 \mathrm{E}-02$ & $3.19 \mathrm{E}-01$ \\
\hline & & Sr-90 & $T c-99$ & $T h-228$ & $T h-230$ \\
\hline IHP & 7 & $4.68 \mathrm{E}-01$ & $6.65 \mathrm{E}-03$ & $1.26 \mathrm{E}-02$ & $4.48 \mathrm{E}-02$ \\
\hline LMBC & 1 & - & - & - & - \\
\hline LWOC & 5 & $2.12 \mathrm{E}-01$ & $2.30 \mathrm{E}-01$ & $3.50 \mathrm{E}-02$ & $5.20 \mathrm{E}-02$ \\
\hline $\mathrm{MMBC}$ & 3 & $2.85 \mathrm{E}-01$ & $4.28 \mathrm{E}-05$ & 4.54E-04 & $1.31 \mathrm{E}-03$ \\
\hline MWOC & 3 & 8.63E-03 & $1.54 \mathrm{E}-03$ & $1.82 \mathrm{E}-03$ & $3.40 \mathrm{E}-03$ \\
\hline $\mathrm{UMBC}^{b}$ & 1 & - & - & - & - \\
\hline \multirow[t]{2}{*}{ Total } & & $9.74 \mathrm{E}-01$ & $2.38 \mathrm{E}-01$ & 4.99E-02 & $1.02 \mathrm{E}-01$ \\
\hline & & $T h-232$ & $U-233 / 234$ & $U-235$ & $U-238$ \\
\hline IHP & 7 & $1.22 \mathrm{E}-02$ & $6.29 \mathrm{E}-02$ & $1.43 \mathrm{E}-02$ & $2.46 \mathrm{E}-02$ \\
\hline LMBC & 1 & - & - & - & - \\
\hline LWOC & 5 & 2.17E-02 & $9.96 \mathrm{E}-02$ & $1.10 \mathrm{E}-02$ & $2.56 \mathrm{E}-02$ \\
\hline MMBC & 3 & 5.72E-04 & $3.92 \mathrm{E}-04$ & $1.42 \mathrm{E}-04$ & $4.31 \mathrm{E}-04$ \\
\hline MWOC & 3 & $1.22 \mathrm{E}-03$ & $1.15 \mathrm{E}-03$ & $1.68 \mathrm{E}-04$ & $1.94 \mathrm{E}-03$ \\
\hline $\mathrm{UMBC}^{b}$ & 1 & - & - & - & - \\
\hline Total & & $3.57 \mathrm{E}-02$ & $1.64 \mathrm{E}-01$ & $2.57 \mathrm{E}-02$ & $5.26 \mathrm{E}-02$ \\
\hline
\end{tabular}

ammediate Holding Pond (IHP ); Lower Melton Branch Creek (LMBC); Lower White Oak Creek (LWOC); Middle Melton Branch Creek (MMBC); Middle White Oak Creek (MWOC); Upper Middle Branch Creek (UMBC).

${ }^{b}$ Because of the small number of observations for UMBC and LMBC, inventory values were not calculated. 
Highest $\mathrm{Cr}$ (IV) inventories are most likely found in Melton Branch Weir sediments, IHP soils, and LWOC soils. Chromium levels in other areas are within the range observed for clean sites in the ORR vicinity. Both $\mathrm{Hg}$ and $\mathrm{Ni}$ inventories are highest in the IHP, dropping further downstream in WOC; levels above that observed for clean areas on the ORR were observed at the WOC weir and throughout the WOC floodplain. Levels in other areas were consistent with noncontaminanted areas in the vicinity of the ORR. 


\section{WALKOVER GAMMA ANALYSIS COMPARISON}

\subsection{SUMMARY OF THE RADIATION WALKOVER DATA}

Radiation walkover of WAG 2 resulted in more than 324,000 measurements, which are mapped as contour data (Fig. 13). Figure 13 includes the results of similar radiation walkover surveys of WAGs 4 and 5 and the main ORNL plant area (WAG 1). Although significant contamination is evident along Melton Branch Creek from HFIR to the confluence of Melton Branch Creek and WOC, higher gamma levels were recorded along WOC, with a trail leading from ORNL to WOL. The highest gamma readings were found in the areas of the IHP just east of SWSA 4 and along LWOC, near WOL.

\subsection{COMPARISON OF CORE AND WALKOVER DATA}

Soil and sediment core inventory data were presented in Sect. 4.2. To further investigate the issue of shielding, and to permit a direct comparison of the walkover and core data, the HEDOSE program that estimates the dose on the basis of the core data alone to an individual standing on the surface was developed. The program uses as input the concentrations of ${ }^{137} \mathrm{Cs}$ and ${ }^{60} \mathrm{Co}$ in each sediment layer, the layer thickness, and the layer density, and returns the effective dose rate to an individual standing on the surface. HEDOSE performs the calculation by interpolating tabulated dose equivalents calculated for a series of plane sources at various depths, then summing the contributions of the individual soil layers (Table 5). The tabulated values used in HEDOSE are from Eckermann and Ryman (1993), who used a sophisticated program to calculate the dose to critical organs (gonad, breast, lung, etc.) for an extensive range of isotopes and for a variety of contaminant vs depth distributions. Calculations included effects of the angular distribution of incoming photons, the transport and energy deposition in organs and tissues in the body, and the energies and intensities of the photons emitted during nuclear transformations. Dose equivalent data for ${ }^{137} \mathrm{Cs},{ }^{137} \mathrm{Ba},{ }^{137} \mathrm{Cs}$ combined with ${ }^{137} \mathrm{Ba}$, and ${ }^{60} \mathrm{Co}$ for plane layer sources up to $60 \mathrm{~cm}$ deep are shown in Table 5 . A bottom depth of $60 \mathrm{~cm}$ was selected because frequently this was the maximum core depth and, based on Table 5 , very little gamma radiation reaches the surface from depths greater than $60 \mathrm{~cm}$.

Analysis of Table 5 indicates that the majority of the gamma radiation measured at the surface comes from the top $20-30 \mathrm{~cm}$. The cumulative dose for a uniform contaminant distribution and a soil density of $1.6 \mathrm{~g} / \mathrm{cm}^{3}$ normalized by the dose from the entire $60 \mathrm{~cm}$ layer for ${ }^{60} \mathrm{Co}$ and ${ }^{137} \mathrm{Cs}$ is illustrated in Fig. 14 . ${ }^{60} \mathrm{Co}$ emits a more energetic gamma ray than ${ }^{137} \mathrm{Ba}$ (the short- lived daughter of ${ }^{137} \mathrm{Cs}$ that actually emits the gamma radiation commonly attributed to ${ }^{137} \mathrm{Cs}$ ), so the cumulative response for ${ }^{60} \mathrm{Co}$ increases slower than for ${ }^{137} \mathrm{Cs}$. For both isotopes, the response is near $90 \%$ by a depth of $20 \mathrm{~cm}$. In other words, for all gamma-emitting radionuclides listed, $90 \%$ of gamma emissions detected at the surface originate in the top $20 \mathrm{~cm}$ of the soil or sediment.

The applicability of gamma walkover data to estimate inventories in the whole soil column depends on the depth of the source (Fig. 14). Core data suggest that most of the contamination in the WAG 2 floodplain is shallow, thus neither variability in nor excessiveness of source - depth are expected to be problems in completing the inventories. Figure 15 is a log-log plot of the gamma walkover data vs the dose equivalent calculated from each core by using HEDOSE. 


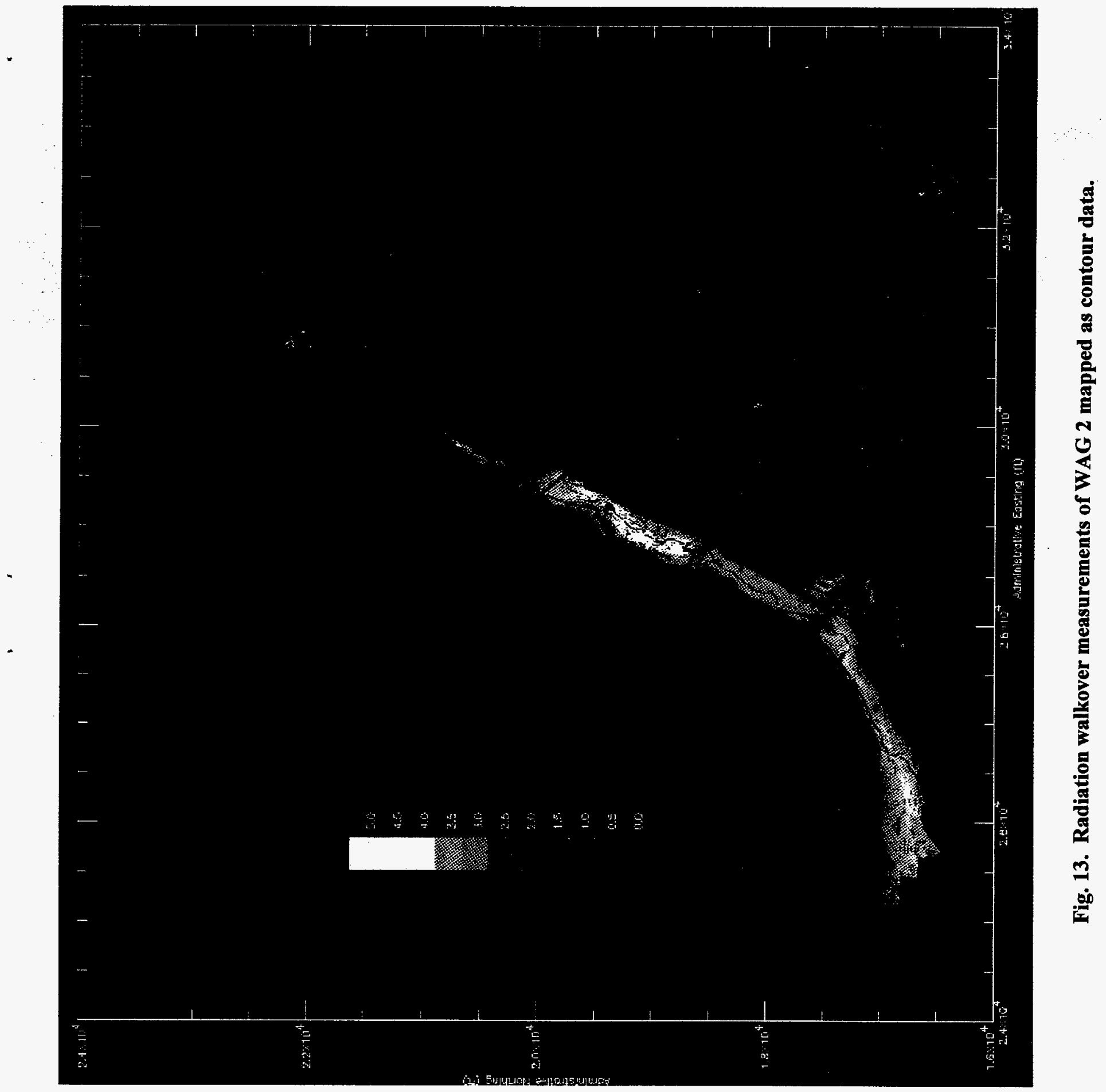


Table 5. Dose equivalent data for ${ }^{137} \mathrm{Cs},{ }^{137} \mathrm{Ba},{ }^{137} \mathrm{Cs}$ combined with ${ }^{137} \mathrm{Ba}$, and ${ }^{60} \mathrm{Co}$ for plane layer sources up to $60 \mathrm{~cm}$ deep

\begin{tabular}{|c|c|c|c|c|}
\hline $\begin{array}{l}\text { Depth } \\
\text { (cm) }\end{array}$ & $\begin{array}{c}{ }^{137} \mathrm{Cs} \\
\left(\mathrm{Gy} / \mathrm{sec} / \mathrm{Bq} / \mathrm{cm}^{2}\right)\end{array}$ & $\begin{array}{c}{ }^{137} \mathrm{Ba} \\
\left(\mathrm{Gy} / \mathrm{sec} / \mathrm{Bq} / \mathrm{cm}^{2}\right)\end{array}$ & $\begin{array}{c}{ }^{137} \mathrm{Cs}+{ }^{137} \mathrm{Ba} \\
\left(\mathrm{Gy} / \mathrm{sec} / \mathrm{Bq} / \mathrm{cm}^{2}\right)\end{array}$ & $\begin{array}{c}{ }^{60} \mathrm{Co} \\
\left(\mathrm{Gy} / \mathrm{sec} / \mathrm{Bq} / \mathrm{cm}^{2}\right)\end{array}$ \\
\hline $\begin{array}{l}0.00 \\
0.05 \\
0.10 \\
0.20 \\
0.30 \\
0.40 \\
0.50 \\
0.75 \\
1.00 \\
1.25 \\
1.50 \\
2.00 \\
2.50 \\
3.00 \\
3.50 \\
4.00 \\
5.00 \\
6.00 \\
7.00 \\
8.00 \\
9.00 \\
10.00 \\
11.00 \\
12.00 \\
13.00 \\
14.00 \\
15.00 \\
16.00 \\
17.00 \\
18.00 \\
19.00 \\
20.00 \\
21.00 \\
22.00 \\
23.00 \\
24.00 \\
25.00 \\
26.00 \\
27.00 \\
28.00 \\
29.00 \\
30.00 \\
31.00 \\
32.00 \\
33.00 \\
34.00 \\
35.00 \\
36.00 \\
37.00 \\
38.00 \\
39.00 \\
40.00 \\
41.00 \\
42.00 \\
43.00 \\
44.00 \\
45.00 \\
46.00 \\
47.00 \\
48.00 \\
49.00 \\
50.00 \\
51.00 \\
52.00 \\
53.00 \\
54.00 \\
55.00 \\
56.00 \\
57.00 \\
58.00 \\
59.00 \\
60.00\end{array}$ & $\begin{array}{l}2.860 \mathrm{E}-19 \\
2.300 \mathrm{E}-19 \\
2.000 \mathrm{E}-19 \\
1.660 \mathrm{E}-19 \\
1.460 \mathrm{E}-19 \\
1.310 \mathrm{E}-19 \\
1.200 \mathrm{E}-19 \\
9.970 \mathrm{E}-20 \\
8.580 \mathrm{E}-20 \\
7.530 \mathrm{E}-20 \\
6.710 \mathrm{E}-20 \\
5.470 \mathrm{E}-20 \\
4.580 \mathrm{E}-20 \\
3.900 \mathrm{E}-20 \\
3.360 \mathrm{E}-20 \\
2.910 \mathrm{E}-20 \\
2.230 \mathrm{E}-20 \\
1.730 \mathrm{E}-20 \\
1.370 \mathrm{E}-20 \\
1.100 \mathrm{E}-20 \\
8.830 \mathrm{E}-21 \\
7.150 \mathrm{E}-21 \\
5.830 \mathrm{E}-21 \\
4.770 \mathrm{E}-21 \\
3.910 \mathrm{E}-21 \\
3.210 \mathrm{E}-21 \\
2.650 \mathrm{E}-21 \\
2.190 \mathrm{E}-21 \\
1.820 \mathrm{E}-21 \\
1.510 \mathrm{E}-21 \\
1.260 \mathrm{E}-21 \\
1.050 \mathrm{E}-21 \\
8.780 \mathrm{E}-22 \\
7.350 \mathrm{E}-22 \\
6.160 \mathrm{E}-22 \\
5.180 \mathrm{E}-22 \\
4.360 \mathrm{E}-22 \\
3.670 \mathrm{E}-22 \\
3.100 \mathrm{E}-22 \\
2.620 \mathrm{E}-22 \\
2.220 \mathrm{E}-22 \\
1.880 \mathrm{E}-22 \\
1.590 \mathrm{E}-22 \\
1.350 \mathrm{E}-22 \\
1.140 \mathrm{E}-22 \\
9.700 \mathrm{E}-23 \\
8.250 \mathrm{E}-23 \\
7.020 \mathrm{E}-23 \\
5.990 \mathrm{E}-23 \\
5.150 \mathrm{E}-23 \\
4.480 \mathrm{E}-23 \\
3.890 \mathrm{E}-23 \\
3.390 \mathrm{E}-23 \\
2.960 \mathrm{E}-23 \\
2.590 \mathrm{E}-23 \\
2.270 \mathrm{E}-23 \\
1.990 \mathrm{E}-23 \\
1.750 \mathrm{E}-23 \\
1.550 \mathrm{E}-23 \\
1.370 \mathrm{E}-23 \\
1.210 \mathrm{E}-23 \\
1.120 \mathrm{E}-23 \\
1.070 \mathrm{E}-23 \\
1.020 \mathrm{E}-23 \\
9.810 \mathrm{E}-24 \\
9.450 \mathrm{E}-24 \\
9.120 \mathrm{E}-24 \\
8.820 \mathrm{E}-24 \\
8.550 \mathrm{E}-24 \\
8.310 \mathrm{E}-24 \\
8.100 \mathrm{E}-24 \\
7.900 \mathrm{E}-24\end{array}$ & $\begin{array}{l}5.870 \mathrm{E}-16 \\
5.460 \mathrm{E}-16 \\
5.090 \mathrm{E}-16 \\
4.450 \mathrm{E}-16 \\
4.030 \mathrm{E}-16 \\
3.750 \mathrm{E}-16 \\
3.540 \mathrm{E}-16 \\
3.110 \mathrm{E}-16 \\
2.820 \mathrm{E}-16 \\
2.590 \mathrm{E}-16 \\
2.410 \mathrm{E}-16 \\
2.120 \mathrm{E}-16 \\
1.880 \mathrm{E}-16 \\
1.680 \mathrm{E}-16 \\
1.520 \mathrm{E}-16 \\
1.390 \mathrm{E}-16 \\
1.170 \mathrm{E}-16 \\
1.010 \mathrm{E}-16 \\
8.690 \mathrm{E}-17 \\
7.510 \mathrm{E}-17 \\
6.520 \mathrm{E}-17 \\
5.670 \mathrm{E}-17 \\
4.960 \mathrm{E}-17 \\
4.350 \mathrm{E}-17 \\
3.840 \mathrm{E}-17 \\
3.390 \mathrm{E}-17 \\
3.000 \mathrm{E}-17 \\
2.660 \mathrm{E}-17 \\
2.360 \mathrm{E}-17 \\
2.090 \mathrm{E}-17 \\
1.860 \mathrm{E}-17 \\
1.650 \mathrm{E}-17 \\
1.460 \mathrm{E}-17 \\
1.300 \mathrm{E}-17 \\
1.160 \mathrm{E}-17 \\
1.030 \mathrm{E}-17 \\
9.150 \mathrm{E}-18 \\
8.140 \mathrm{E}-18 \\
7.240 \mathrm{E}-18 \\
6.450 \mathrm{E}-18 \\
5.740 \mathrm{E}-18 \\
5.110 \mathrm{E}-18 \\
4.560 \mathrm{E}-18 \\
4.060 \mathrm{E}-18 \\
3.620 \mathrm{E}-18 \\
3.230 \mathrm{E}-18 \\
2.890 \mathrm{E}-18 \\
2.580 \mathrm{E}-18 \\
2.300 \mathrm{E}-18 \\
2.060 \mathrm{E}-18 \\
1.840 \mathrm{E}-18 \\
1.640 \mathrm{E}-18 \\
1.470 \mathrm{E}-18 \\
1.310 \mathrm{E}-18 \\
1.170 \mathrm{E}-18 \\
1.050 \mathrm{E}-18 \\
9.380 \mathrm{E}-19 \\
8.380 \mathrm{E}-19 \\
7.500 \mathrm{E}-19 \\
6.710 \mathrm{E}-19 \\
6.000 \mathrm{E}-19 \\
5.350 \mathrm{E}-19 \\
4.750 \mathrm{E}-19 \\
4.220 \mathrm{E}-19 \\
3.740 \mathrm{E}-19 \\
3.320 \mathrm{E}-19 \\
2.940 \mathrm{E}-19 \\
2.610 \mathrm{E}-19 \\
2.310 \mathrm{E}-19 \\
2.040 \mathrm{E}-19 \\
1.810 \mathrm{E}-19 \\
1.600 \mathrm{E}-19\end{array}$ & $\begin{array}{l}5.873 \mathrm{E}-16 \\
5.462 \mathrm{E}-16 \\
5.092 \mathrm{E}-16 \\
4.452 \mathrm{E}-16 \\
4.031 \mathrm{E}-16 \\
3.751 \mathrm{E}-16 \\
3.541 \mathrm{E}-16 \\
3.111 \mathrm{E}-16 \\
2.821 \mathrm{E}-16 \\
2.591 \mathrm{E}-16 \\
2.411 \mathrm{E}-16 \\
2.121 \mathrm{E}-16 \\
1.880 \mathrm{E}-16 \\
1.680 \mathrm{E}-16 \\
1.520 \mathrm{E}-16 \\
1.390 \mathrm{E}-16 \\
1.170 \mathrm{E}-16 \\
1.010 \mathrm{E}-16 \\
8.691 \mathrm{E}-17 \\
7.511 \mathrm{E}-17 \\
6.521 \mathrm{E}-17 \\
5.671 \mathrm{E}-17 \\
4.961 \mathrm{E}-17 \\
4.350 \mathrm{E}-17 \\
3.840 \mathrm{E}-17 \\
3.390 \mathrm{E}-17 \\
3.000 \mathrm{E}-17 \\
2.660 \mathrm{E}-17 \\
2.360 \mathrm{E}-17 \\
2.090 \mathrm{E}-17 \\
1.860 \mathrm{E}-17 \\
1.650 \mathrm{E}-17 \\
1.460 \mathrm{E}-17 \\
1.300 \mathrm{E}-17 \\
1.160 \mathrm{E}-17 \\
1.030 \mathrm{E}-17 \\
9.150 \mathrm{E}-18 \\
8.140 \mathrm{E}-18 \\
7.240 \mathrm{E}-18 \\
6.450 \mathrm{E}-18 \\
5.740 \mathrm{E}-18 \\
5.110 \mathrm{E}-18 \\
4.560 \mathrm{E}-18 \\
4.060 \mathrm{E}-18 \\
3.620 \mathrm{E}-18 \\
3.230 \mathrm{E}-18 \\
2.890 \mathrm{E}-18 \\
2.580 \mathrm{E}-18 \\
2.300 \mathrm{E}-18 \\
2.060 \mathrm{E}-18 \\
1.840 \mathrm{E}-18 \\
1.640 \mathrm{E}-18 \\
1.470 \mathrm{E}-18 \\
1.310 \mathrm{E}-18 \\
1.170 \mathrm{E}-18 \\
1.050 \mathrm{E}-18 \\
9.380 \mathrm{E}-19 \\
8.380 \mathrm{E}-19 \\
7.500 \mathrm{E}-19 \\
6.710 \mathrm{E}-19 \\
6.000 \mathrm{E}-19 \\
5.350 \mathrm{E}-19 \\
4.750 \mathrm{E}-19 \\
4.220 \mathrm{E}-19 \\
3.740 \mathrm{E}-19 \\
3.320 \mathrm{E}-19 \\
2.940 \mathrm{E}-19 \\
2.610 \mathrm{E}-19 \\
2.310 \mathrm{E}-19 \\
2.040 \mathrm{E}-19 \\
1.810 \mathrm{E}-19 \\
1.600 \mathrm{E}-19\end{array}$ & $\begin{array}{l}2.360 \mathrm{E}-15 \\
2.210 \mathrm{E}-15 \\
2.080 \mathrm{E}-15 \\
1.840 \mathrm{E}-15 \\
1.640 \mathrm{E}-15 \\
1.510 \mathrm{E}-15 \\
1.420 \mathrm{E}-15 \\
1.260 \mathrm{E}-15 \\
1.140 \mathrm{E}-15 \\
1.050 \mathrm{E}-15 \\
9.740 \mathrm{E}-16 \\
8.630 \mathrm{E}-16 \\
7.740 \mathrm{E}-16 \\
6.990 \mathrm{E}-16 \\
6.360 \mathrm{E}-16 \\
5.810 \mathrm{E}-16 \\
4.940 \mathrm{E}-16 \\
4.280 \mathrm{E}-16 \\
3.750 \mathrm{E}-16 \\
3.320 \mathrm{E}-16 \\
2.950 \mathrm{E}-16 \\
2.610 \mathrm{E}-16 \\
2.320 \mathrm{E}-16 \\
2.070 \mathrm{E}-16 \\
1.850 \mathrm{E}-16 \\
1.660 \mathrm{E}-16 \\
1.490 \mathrm{E}-16 \\
1.340 \mathrm{E}-16 \\
1.210 \mathrm{E}-16 \\
1.100 \mathrm{E}-16 \\
9.920 \mathrm{E}-17 \\
9.010 \mathrm{E}-17 \\
8.180 \mathrm{E}-17 \\
7.440 \mathrm{E}-17 \\
6.760 \mathrm{E}-17 \\
6.150 \mathrm{E}-17 \\
5.580 \mathrm{E}-17 \\
5.080 \mathrm{E}-17 \\
4.620 \mathrm{E}-17 \\
4.210 \mathrm{E}-17 \\
3.840 \mathrm{E}-17 \\
3.500 \mathrm{E}-17 \\
3.200 \mathrm{E}-17 \\
2.920 \mathrm{E}-17 \\
2.670 \mathrm{E}-17 \\
2.440 \mathrm{E}-17 \\
2.230 \mathrm{E}-17 \\
2.040 \mathrm{E}-17 \\
1.860 \mathrm{E}-17 \\
1.700 \mathrm{E}-17 \\
1.560 \mathrm{E}-17 \\
1.430 \mathrm{E}-17 \\
1.310 \mathrm{E}-17 \\
1.200 \mathrm{E}-17 \\
1.100 \mathrm{E}-17 \\
1.010 \mathrm{E}-17 \\
9.210 \mathrm{E}-18 \\
8.450 \mathrm{E}-18 \\
7.750 \mathrm{E}-18 \\
7.110 \mathrm{E}-18 \\
6.520 \mathrm{E}-18 \\
5.990 \mathrm{E}-18 \\
5.500 \mathrm{E}-18 \\
5.050 \mathrm{E}-18 \\
4.650 \mathrm{E}-18 \\
4.270 \mathrm{E}-18 \\
3.930 \mathrm{E}-18 \\
3.620 \mathrm{E}-18 \\
3.330 \mathrm{E}-18 \\
3.070 \mathrm{E}-18 \\
2.830 \mathrm{E}-18 \\
2.600 \mathrm{E}-18\end{array}$ \\
\hline
\end{tabular}




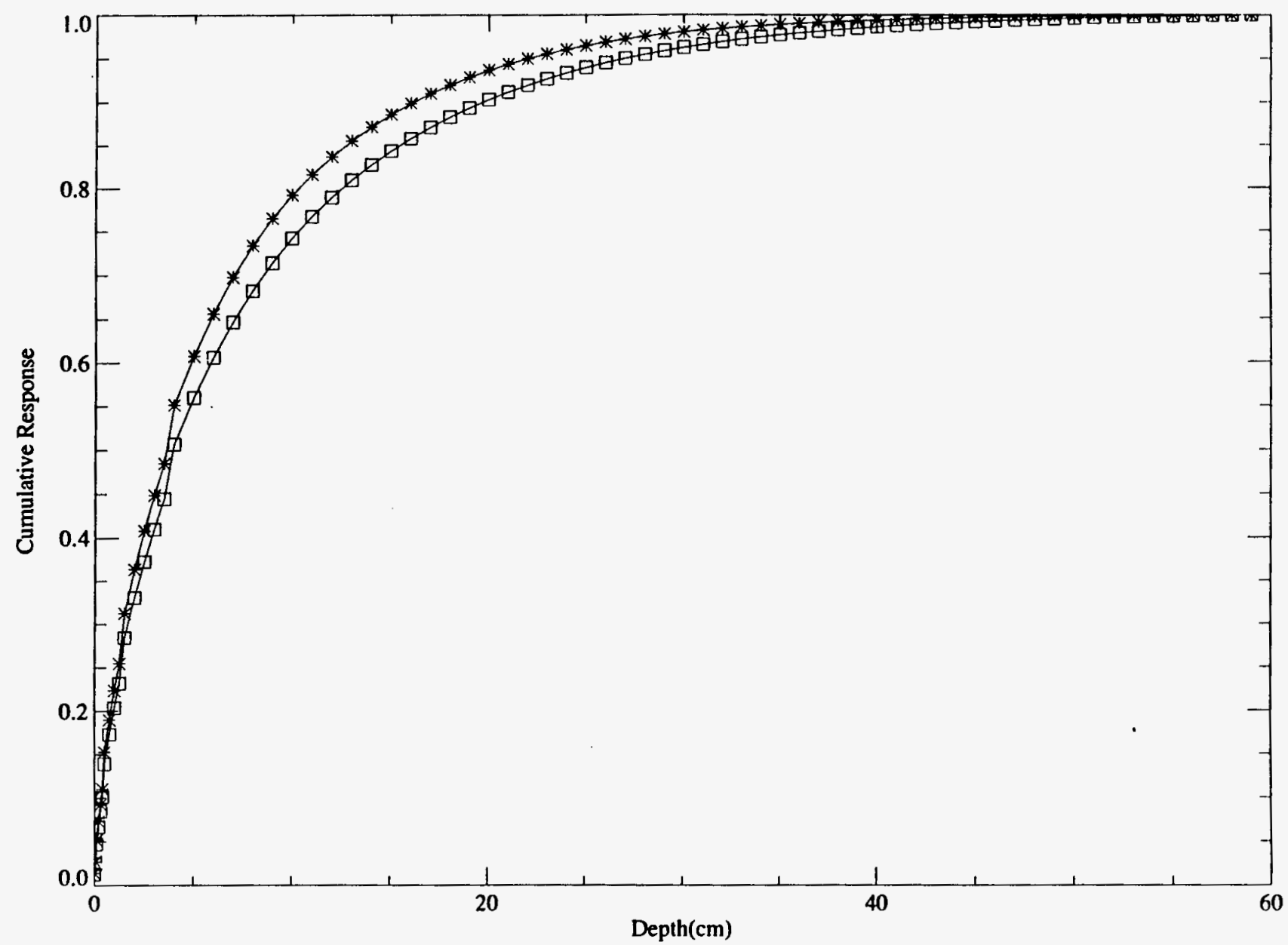

Fig. 14. Cumulative dose for a uniform contaminant distribution and a soil density of $1.6 \mathrm{~g} / \mathrm{cm}^{3}$, normalized by dose from the entire $60 \mathrm{~cm}$ layer for ${ }^{137} \mathrm{Cs}$ and ${ }^{60} \mathrm{Co}$. 


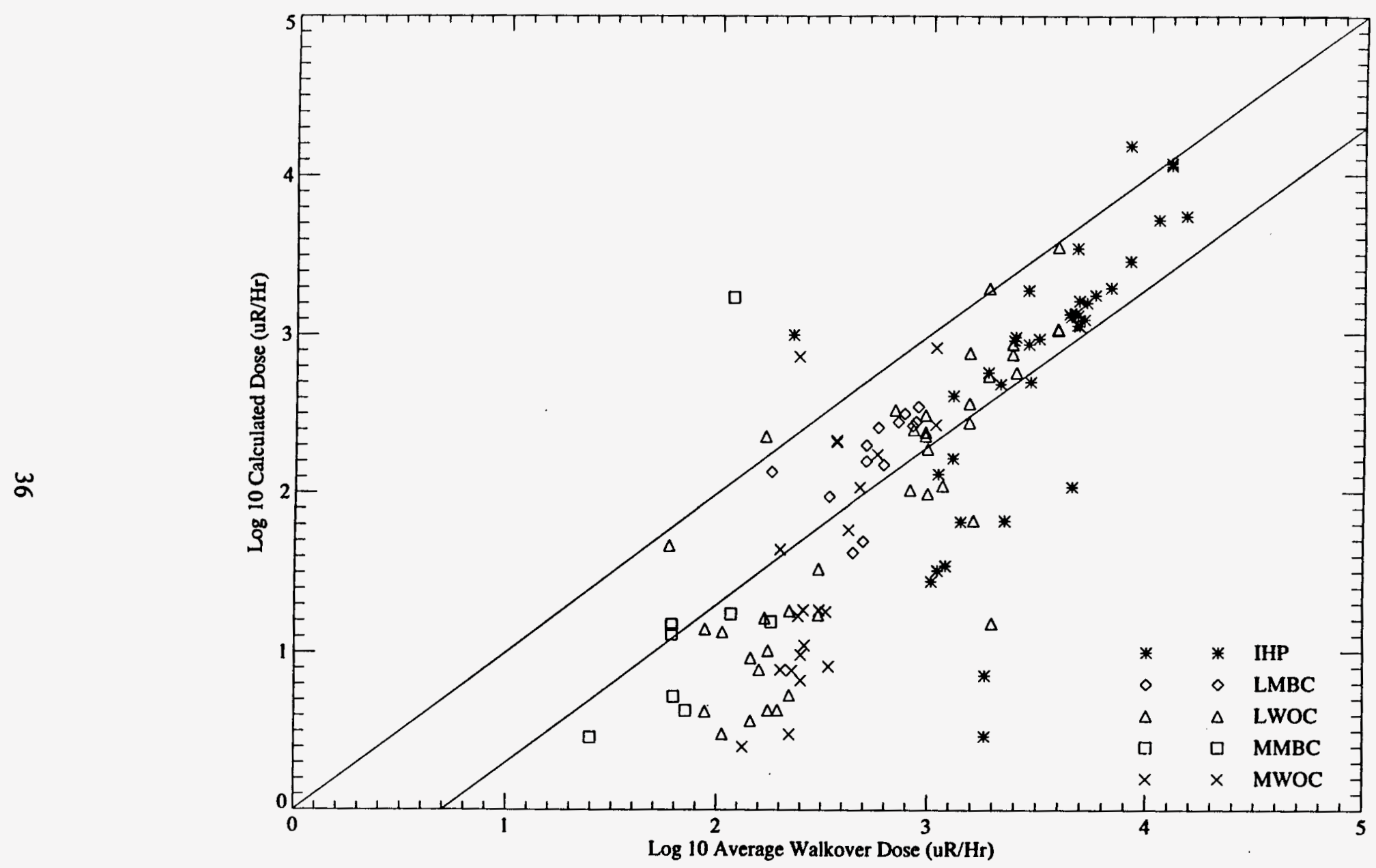

Fig. 15. $\log _{10}-\log _{10}$ plot of gamma walkover data vs the dose equivalent calculated from soil and sediment cores in the WAG 2 foodplain. 
The walkover dose rates corresponding to the core measurements were computed by averaging all values within a $20 \mathrm{ft}$ box centered on the core. Cores collected outside the bounds of the walkover survey were excluded from the plot. In most cases the variation of walkover readings within a $20 \mathrm{ft}$ square were quite small.

The walkover values are systematically higher than the dose rates calculated from the cores. Two factors contribute to the higher walkover dose rate. First, the gamma scintillometer used in the walkover was calibrated to give the correct dose rates assuming that the gamma radiation measured is the $0.66 \mathrm{MeV}$ gamma emitted by ${ }^{137} \mathrm{Ba}$. But gamma radiation emitted by buried radionuclides is shifted by Compton scattering; the photons lose energy when they collide with soil atoms on their way to the surface. Consequently, photons striking the detector may have any energy up to the original $0.66 \mathrm{MeV}$. However, the $\mathrm{NaI}$ detector captures lower energy gamma photons more efficiently than higher energy photons, so the count rate will be higher for the same photon flux when the average photon energy has been reduced by scattering. Because the conversion of count rate to dose rate was calibrated assuming monoenergetic $0.66 \mathrm{MeV}$ photons, the dose rate (related to the total energy per unit time deposited in body tissues) is overestimated. In a walkover survey at SWSA 4 conducted after the WAG 2 walkover, a special energycompensated dose rate meter (Bicron model 1056000 microrem meter) was included along with the same instrument used at WAG 2. The data showed that the instrument used at WAG 2 consistently read 4-5 times too high in this area. The dose rates calculated by HEDOSE use dose equivalents that allow for the degradation of the energy spectrum by collisional losses in the soil (Table 5). Consequently, on Fig. 15 we have included a line representing a one-fifth reduction in the gamma walkover data, which is expected to better correlate with the calculate dose rate.

The second factor contributing to the higher walkover dose rate is gamma-shine. The gamma scintillometer used in the walkover survey was sensitive to both gamma radiation coming from the soil directly beneath the probe and to radiation coming from adjacent areas. In particular, this explains why the walkover values from IHP never fall below $1000 \mathrm{uR} / \mathrm{Hr}$, whereas the corresponding dose rates calculated from the cores are as low as $10 \mathrm{uR} / \mathrm{Hr}$. In Fig. 13, the entire IHP is elevated in the walkover data and shine from IHP is apparent across the length of WAG 4. Shine is also apparent in the ORNL plant areas where the scintillometer picked up radiation emissions from the waste ponds as well as some of the buildings. Shine has the unfortunate consequence of elevating the gamma reading in uncontaminated areas adjacent to highly contaminated areas. The true extent boundaries of contamination can only be fully determined through the use of cores or a shielded scintillometer. However, shine does contribute to dose and therefore, should be included in exposure assessment. A person walking past a contaminated area can receive a significant dose from shine.

Walkover data are more exhaustive in coverage than core data because of the nature of sample collection. The locations of the walkover measurements (small dots) and core samples (large dots) are shown in Fig. 16 for the confluence of Melton Branch Creek and WOC.

Figure 17 shows the color-coded exposure rates from the same area as the walkover data in Fig. 16. From Fig. 17, it is clear that an exposure based only on core samples would be in error. The core data does not include samples from the area roughly centered on $28000 \mathrm{E}, 17700 \mathrm{~N}$ (ORNL grid) in Fig. 17, which has the highest readings in the walkover data for this area. The walkover data has advantages over the core data as a basis for assessing human health exposure to gamma radiation at WAG 2 . However, walkover data alone provide no information as to the 


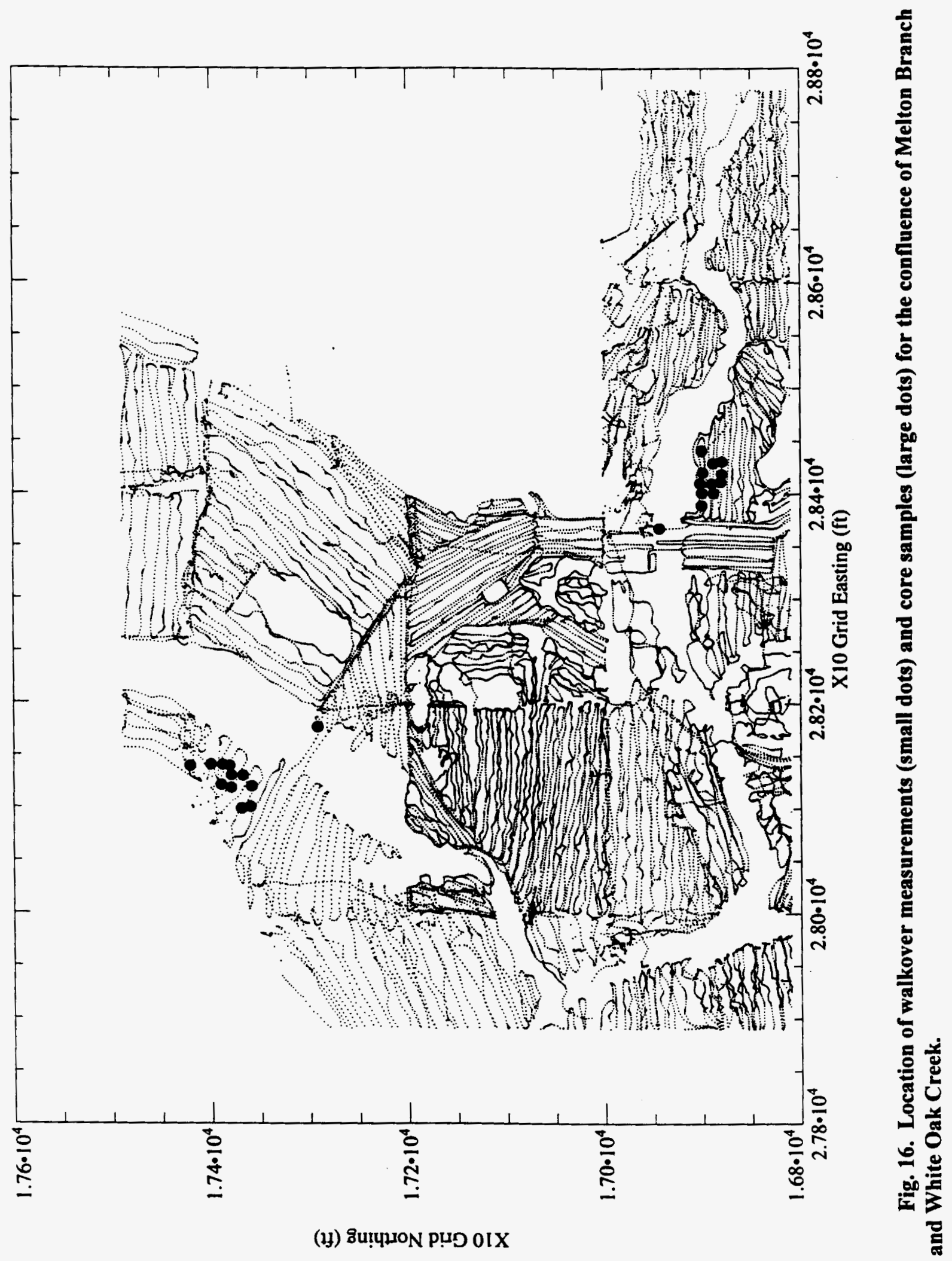




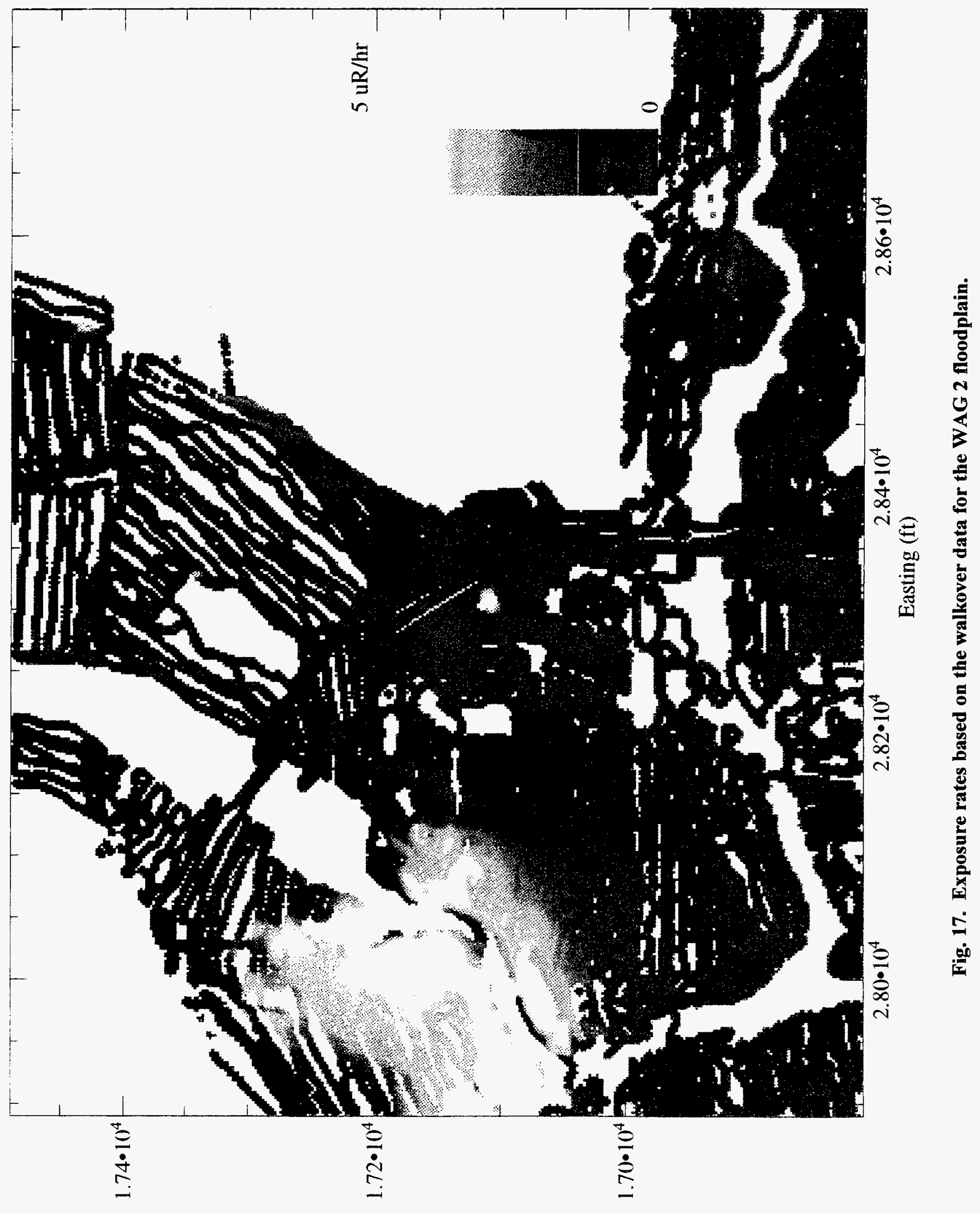

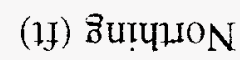


depth of contamination within the area; such information is fundamental to the remedial investigation feasability study. Combined with the HEDOSE program, walkover data and integrated core samples provide a much more coherent image as to the extent of contamination in the WAG 2 floodplain. The HEDOSE software program developed to calculate effective dose from core data is of potential benefit for comparing remediation alternatives. HEDOSE could be used, for example, to investigate the consequences of erosion exposing deeper contamination or the benefits of placing a layer of clean soil over the most highly contaminated areas. 


\section{HUMAN HEALTH EXPOSURE ASSESSMENT}

This human health exposure assessment documents the potential risk resulting from exposure to floodplain soils and weir sediments in the WOC watershed. The six areas presented in Sect. 2 are analyzed individually for the risk assessment for three different exposure scenarios. For all three, the primary concern from contaminants within the floodplain soils and sediments is from the external exposure risk due to gamma-emitting radionuclides. This assessment examines three methods for calculating the risk due to gamma exposure by (1) calculating risk based solely on the soil and sediment concentration results (presented in Sect. 4) and established EPA guidance (EPA 1989); (2) deriving an exposure dose rate based on the walkover data (presented in Sect. 5), and (3) modeling dose rates based on the HEDOSE program. The risk results for these approaches are compared. For all other contaminants of concern and pathways, existing soil and sediment sample concentration results and EPA guidance are used to assess the risk.

\subsection{SCENARIOS}

Exposure scenarios for this assessment were selected after evaluation of land use and exposure pathways. Exposure scenarios are defined by the complete or potential exposure pathways that are likely to exist for a known or potential receptor population. The potential receptors are identified based on current and future land use considerations. A decision on the specific land use used for establishing cleanup levels will ultimately be reached in a consensus agreement between involved stakeholders.

The conceptual model for the future residential, industrial, and recreational land use scenarios that are evaluated in this report for WAG 2 floodplain soil and sediment is presented in Fig. 18. This model illustrates the results of the exposure pathway evaluation. These exposure pathways were selected as potential pathways of concern at WAG 2 on the basis of agreements with stakeholders about the scenarios and pathways that need to be evaluated for human health risk assessments at DOE-ORR sites (LMES 1996) and on the nature of the contaminated site (floodplain soil and sediment). Sources of contamination may be considered to be primary or secondary in nature. The main plant area and source areas within the watershed are considered to be the primary sources of contamination. Secondary sources of contamination are the contaminated media that have been identified at WAG 2. For this assessment, the sediment and the floodplain soils are considered as secondary sources in the conceptual model. These sources can be resuspended and deposited in other areas. Therefore, the air pathway is also considered as a potential secondary source of contamination. The evaluation of release mechanisms identifies potentially contaminated environmental media on the basis of the physical and chemical properties of the contaminants and the characteristics of the media where they are found. For this assessment, leaching and plant releases/operation spills are the primary release mechanisms that are the historical cause of the contamination of the WAG 2 floodplain. The primary exposure pathways of concern chosen for the assessment (Fig. 18) are described in Sect. 6.2. 


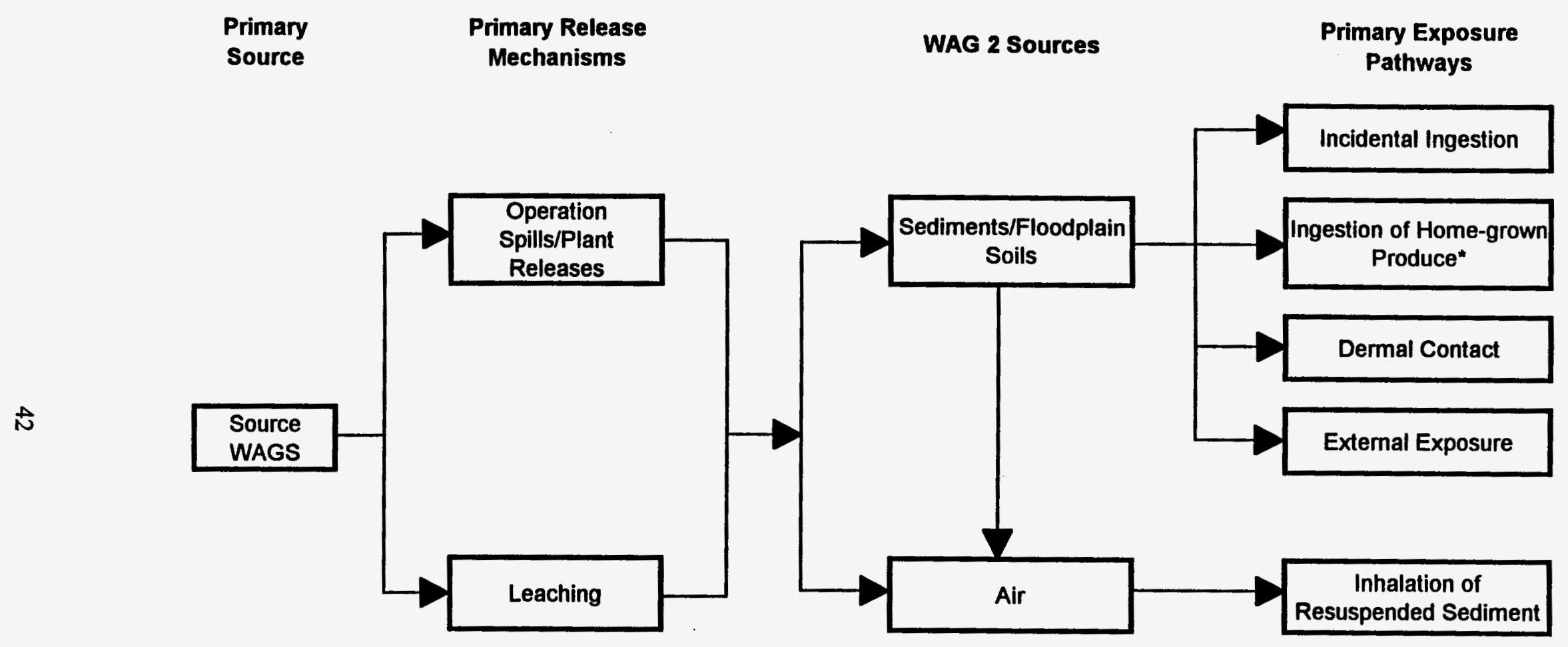

* This pathway is evaluated for the residential scenario only

Fig. 18. Preliminary conceptual model for all receptors on WAG 2. 


\subsubsection{Current Land Use}

Because WAG 2 is located within the confines of ORNL, public access is currently denied. No actively used office or laboratory buildings are located within the vicinity of WAG 2 . For these reasons, current land use is designated as "restricted industrial," and no current on-WAG exposure scenarios are evaluated.

\subsubsection{Future Land Use}

If institutional controls were removed from WAG 2, future populations could be adversely affected by existing site contamination. Because the future land use for WAG 2 has not yet been determined, the risks associated with various land use scenarios have been evaluated. Three future land use scenarios are considered in this report: industrial, residential, and recreational. The purpose of evaluating future land use scenarios as part of the risk assessment is to establish whether remedial action is necessary for alternate land uses by determining if the cumulative risk or hazard index (HI) from the source areas could exceed levels of concern. The WAG 2 future land use scenario is based on the assumption that industrial workers, residents, or recreational users of WAG 2 could be exposed. Current contaminant concentrations are used for the on-site assessment of future exposure. This represents the maximum exposure to WAG 2 contaminants and will serve to define the potential human health risks that would exist if residential occupation were to begin within a short time frame.

\subsubsection{Industrial land use}

Under this scenario, industrial workers are expected to be routinely exposed to contaminated media within a commercial area or industrial site. The future industrial scenario is evaluated by using industrial default occupational values provided by EPA (1991a,b) and LMES (1996) guidance. Because the potential exists in an unrestricted industrial scenario for the use of heavy equipment and related traffic in and around the contaminated site, soils and sediment could be disturbed, thus producing particulate emissions that could then be inhaled by the industrial worker. It should be noted that the assumptions and default parameters for the industrial land use scenario are reasonable maximum values (RME) and do not reflect the use of protective clothing or other safety precautions.

\subsubsection{Residential land use}

Under residential land use, future residents are expected to be in frequent, repeated contact with contaminated media. The assumptions in this scenario account for daily long-term exposure and generally result in the highest potential exposures and risk. The future residential scenario is evaluated by using default occupational values provided in EPA (1991a,b) and LMES (1996) guidance. In an industrial area where redevelopment for homes is not feasible now or in the foreseeable future, future land use planning scenarios would be more accurately reflected as industrial rather than residential. However, to provide a conservative assessment of risk, a residential land use scenario is assumed as one of the potential receptors for this assessment. Consequently, appropriate default parameters and equations for residential land use were evaluated. An off-WAG residential land use scenario was not investigated for this report. It would provide human health risk results for contamination which could potentially migrate from the WAG 2 area. However, risks resulting from WAG2 floodplain soils and sediments for the 
off-WAG residential scenario is addressed as part of the sediment transport modeling task (Clapp et al. 1996).

Under the residential land use scenario, residents are expected to be continuously exposed to contaminated media. Exposure is higher than that under the industrial scenarios because exposure is more frequent and lasts longer. Exposure is calculated for a lifetime, which includes exposures for the receptor as both child and adult.

\subsubsection{Recreational land use}

This scenario addresses exposure to people who spend a limited amount of time at or near WAG 2 while engaging in outdoor activities such as fishing, hunting, and hiking. The recreational land use scenario is also referred to as the "trespasser" or "site visitor" scenario. The future recreational scenario is evaluated by using default exposure values provided in EPA (1991 a,b) and LMES (1996) guidance.

\subsection{IDENTIFICATION OF EXPOSURE PATHWAYS}

The exposure pathways evaluated in this assessment are discussed in this section. Each exposure pathway describes a single mechanism by which an individual or a population may be exposed to chemicals originating from the site. Exposure pathways of concern are identified by evaluating all components (i.e., source and mechanism of chemical release, transport medium, exposure point, potential human receptors, routes of exposure) necessary to complete the potential exposure pathway. For an exposure pathway to be considered complete, each component must be identified and must be linked to each of the other components. Routes of exposure (i.e., ingestion, inhalation, dermal absorption, external exposure to radiation) and potential receptors are crucial in identifying the validity of an exposure pathway. The descriptions of exposure pathways are presented for each on-WAG future land use exposure.

\subsubsection{Future On-WAG Industrial Scenario}

Floodplain soils and sediments were considered the primary source of exposure to potential industrial receptors. The exposure pathways evaluated include incidental ingestion, dermal contact, inhalation of wind-generated dust particulates, and external exposure to radionuclides in the soil.

\subsubsection{Future On-WAG Residential Scenario}

Floodplain soils and sediments were considered the primary source of exposure to potential on-WAG residential receptors. The exposure pathways evaluated include incidental ingestion, dermal contact, inhalation of wind-generated dust particulates, external exposure to radionuclides in the soil, and ingestion of home-grown produce cultivated in contaminated soil and sediment.

\subsubsection{Future On-WAG Recreational Scenario}

Floodplain soils and sediments were considered the primary source of exposure to potential recreational receptors. The exposure pathways evaluated include incidental ingestion, dermal 
contact, inhalation of wind-generated dust particulates, and external exposure to radionuclides in the soil.

\subsection{QUANTIFICATION OF EXPOSURE}

Exposure is quantified by determining the exposure concentrations and by calculating the chemical intakes for the various exposure pathways identified for WAG 2. The chronic daily intake (CDI) is the amount of a contaminant an individual takes into his or her body per day through ingestion, inhalation, dermal contact, or external exposure to radiation. The first consideration in deriving the $\mathrm{CDI}$ is the methodology employed in developing an exposure concentration, which is the amount of each contaminant in the various media to which receptors are exposed. To calculate the CDI, the exposure concentration is evaluated in the context of the scenario, exposure pathway, and contaminant-specific exposure variables, such as duration of exposure and intake rate. The representative concentrations of the contaminants of potential concern (COPCs) are the concentrations used to estimate the RME exposure concentrations for the different pathways. Once the CDIs for the different potential pathways are determined, risk can be calculated. Tables 3-18 of Purucker and Douthat (1996) list the equations used to calculate the CDIs and the exposure variables associated with each exposure pathway considered for the different land use scenarios.

In addition to concentration-based CDIs, CDIs based on dose were produced for each of the six areas based on dose estimates generated from the upper 95th confidence limit on the mean of the dose results from the USRADs walkover and also based on the dose results from the output of the HEDOSE model.

\subsubsection{Calculations for the Industrial Land Use Scenario}

The exposure assumptions associated with all exposure routes included in the industrial land use scenario are listed in Tables 3-6 of Purucker and Douthat (1996). The media concentrations of the COPCs identified were used in calculating the CDIs. The smallest of either the maximum detected concentration or the upper 95 th confidence limit concentration was assumed to represent the analyte concentration. Conservative CDI calculations were based on the assumption that an adult spends 8 hours per day, 5 days per week, and 50 weeks per year for 25 years at the facility. Parameters are industrial default occupational values provided by EPA (EPA 1991 a,b) and LMES (1996) guidance. It is important to note that the assumptions and default parameters for the industrial land use scenario are reasonable maximum values and do not reflect the use of protective clothing or other safety precautions. The scenario evaluates risk to the general plant employee only and does not evaluate risk to remediation workers.

\subsubsection{Calculations for the Residential Land Use Scenario}

The exposure assumptions and parameters associated with all exposure routes included in the future residential land use scenario are provided in Tables 7-11 of Purucker and Douthat (1996). For the hypothetical future residential land use scenario, the residential defaults as provided by EPA guidance are used to calculate the CDIs for a person exposed for 6 years as a child and 24 years as an adult (EPA $1991 \mathrm{a}, \mathrm{b}$ ). The exposure frequency to soil contaminants was assumed to be 350 days per year for an exposure duration of 30 years. 
6.3.2.1 CDI calculations for ingestion of produce. Another route of potential exposure includes residential ingestion of produce grown in floodplain soil and sediment of WAG 2.

Table 11 (Purucker and Douthat 1996) presents the CDI equations and corresponding parameters used for the ingestion of produce. The concentrations of contaminants used in the CDI calculations were derived through the use of bioconcentration factors. To calculate the CDI for ingestion of produce, an estimate of the contaminant concentrations in produce was determined for each of the identified areas.

The plant concentration due to root uptake, $C_{n}$ is estimated by equation 5 ,

$$
C_{r}=B_{v} \times C_{s}
$$

where $B_{v}$ is the soil-to-plant transfer coefficient which is dimensionless and $C_{s}$ is the concentration in the dry soil in $\mathrm{mg} / \mathrm{kg}$ or $\mathrm{pCi} / \mathrm{g}$.

\subsubsection{Calculations for the Recreational Land Use Scenario}

The exposure assumptions associated with all exposure routes included in the recreational land use scenario are listed in Tables 15-18 of Purucker and Douthat (1996). For the hypothetical future recreational land use scenario, the defaults as provided by EPA guidance are used to calculate the CDIs for a person exposed for 6 years as a child and 24 years as an adult. The exposure frequency was assumed to be 1 hour a day, for 75 days per year with an exposure duration of 30 years. Parameters are recreational default values provided by EPA (1991a,b) and LMES (1996) guidance.

\subsection{RISK CHARACTERIZATION}

The purpose of the risk characterization is to integrate and summarize the information presented in the exposure and toxicity assessments for each of the different land use scenarios. This represents the final step in the human health risk assessment process. Potential carcinogenic effects are characterized by estimating the probability that an individual will develop cancer over a lifetime from projected intakes (and exposures) and chemical-specific dose-response data [i.e., Slope Factors (SFs)]. Potential noncarcinogenic (systemic) effects are characterized by comparing projected intakes of contaminants with toxicity values [i.e., Reference Doses (RfDs)]. The numerical risk, or hazard quotient (HQ) estimates that are presented in this section must be interpreted in the context of the uncertainties and assumptions associated with the risk assessment process and the data on which the risk estimates are based.

\subsubsection{Evaluation of Carcinogens and Noncarcinogens}

Carcinogenic risk and noncarcinogenic hazard potential for carcinogens and noncarcinogens, respectively, are calculated for the WAG 2 soil and sediment COPCs. These risks and hazard potential are based on EPA-approved or -suggested SFs and RfDs. The SF is based on an estimate of the incremental lifetime cancer risk, which equates to incidence per unit of exposure, and the RfD is a level of exposure (threshold) below which noncarcinogenic adverse health effects are not expected to occur. 
Cancer risk is an estimate of the incremental probability of developing excess cancer over a lifetime (EPA 1989), above and beyond the normal (unavoidable) incidence observed in the general population. The risk estimates for carcinogens are calculated by multiplying the EPAapproved SFs for inorganics, organics, and radionuclides by an estimate of the actual exposure to these contaminants (i.e., CDI and/or dose) through the different pathways ingestion, inhalation, dermal contact, or external exposure. The risk equation (intake $\times \mathrm{SF}=$ risk) is based on the assumption that a linear relationship exists between dose and response (cancer incidence) (EPA 1989). The assumption that dose-response is linear is reliable only for predicting risk at low exposure levels; therefore, the application of the above equation is limited to risks below 1E-02. At high exposure levels ( $21 \mathrm{E}-02$ ), which is frequently the case for WAG 2 because of to the high level of activity associated with radionuclides in various media, the one-hit equation [risk =1 exponential (-CDI $\times$ SF)] was applied to estimate risk (EPA 1989). Because some risks were calculated with the one-hit equation and others with the linear equation, the sum of the risk numbers mentioned in the text for individual analytes or exposure routes may not equal the total scenario risk referenced. This may also occur as a result of rounding associated with the estimation of cancer risks, which are typically reported to one significant figure.

The HQ estimates for noncarcinogens are calculated by determining the ratio of the CDI for ingestion, inhalation, and dermal contact of a contaminant to the contaminant-specific reference toxicity value $[\mathrm{RfD}$, Reference Concentration $(\mathrm{RfC})]$. This $\mathrm{HQ}$ assumes that below a given level of chronic exposure (i.e., the $\mathrm{RfD}$ ) populations are unlikely to experience adverse health effects.

The risks and HQs are summed for all contaminants in a particular pathway in order to estimate the potential risk to human health from all contaminants in that pathway. In other words, a cumulative risk (total pathway risk) or a cumulative hazard quotient (total pathway HQ) is determined from exposure to all contaminants (EPA 1989). In addition, an overall cumulative risk caused due to site contaminants can be determined by summing the risks from all analytes from all of the pathways associated with a specific land use. Summations are conducted separately for chemicals (either carcinogens, noncarcinogens, or radionuclides.)

The constituents detected in the WAG 2 media and listed as COPCs were evaluated within the context of EPA-approved guidelines (EPA 1989), which describe three regions of interest for carcinogenic risk [risk $<1.0 \mathrm{E}-06$, no concern; risk between 1.0E-06 and 1.0E-04, range of concern (or target risk range); and risk $\geq 1.0 \mathrm{E}-04$, concern] and two areas of interest in terms of noncarcinogenic/systemic toxicity ( $\mathrm{HI}<1.0$, no concern, and $\mathrm{HI} \geq 1.0$, concern). These boundaries allow an optional screening analysis to be performed to prioritize the large number of detected chemicals. The Contaminants of Concern (COCs) that contribute to risks exceeding the target risk range in the Baseline Human Health Risk Assessment in each area within WAG 2 were identified on the basis of the total pathway risk or HQ in an effort to limit the number of chemicals to be considered. That is, if the total pathway risk or HQ is high (total pathway risk $\geq 1 \mathrm{E}-04$, or total pathway HQ $\geq 1.0$ ), then all COPCs with individual risks $\geq 1 \mathrm{E}-06$ or an HQ $\geq 0.1$ are considered COCs.

\subsubsection{Risk Summary by Land Use}

The risk characterization for the assessment includes potential risks determined as a result of exposure to floodplain soils and sediments. The risk estimates associated with exposure are presented by effect (carcinogenic or noncarcinogenic) and by land use (industrial, recreational, and residential). 
The data used to conduct this assessment is divided as described in Sect. 2 (IHP, MWOC, LWOC, LMBC, MMBC and UMBC). In addition, the radionuclide data collected for each area was divided into the following surface and subsurface categories. The surface includes all data collected from a depth of 0 to $15 \mathrm{~cm}$ below the ground surface. The subsurface includes the radionuclide data collected from a depth $15 \mathrm{~cm}$ below the surface soil.

6.4.2.1 Residential scenario-carcinogenic results. The carcinogenic risks to a future on-WAG resident were determined for exposure to floodplain soils and sediments through incidental ingestion, dermal contact, inhalation of wind-generated dust and particulates, external exposure to radionuclides, and ingestion of produce. Table 6 provides a summary of the risk estimates for the exposure of a future resident to the WAG 2 carcinogenic COCs in the floodplain soils and sediments for the radionuclide surface data $(0-15 \mathrm{~cm}$ below the ground surface) and for the collected metals and organic data. The tables include the individual risk estimates for each exposure pathway and the total risk from all the exposure pathways (sum of the individual exposure pathways). In addition, the contaminant, along with the risk estimate and exposure pathway (for this contaminant), with the greatest contribution to the overall carcinogenic risk is also included in the summary tables. Total risk to the hypothetical on-WAG resident is caused primarily by external exposure to radionuclides. The contaminants detected in WAG 2 that drive the risk values for external exposure are ${ }^{137} \mathrm{Cs}$ and ${ }^{60} \mathrm{Co}$. Cesium-137 is the major contaminant for the IHP, LWOC, LMBC, and MWOC areas, whereas ${ }^{60} \mathrm{Co}$ is the primary contaminant for the UMBC area. The risk in the $\mathrm{MMBC}$ area is driven from ${ }^{90} \mathrm{Sr}$ in the produce ingestion pathway. For example, the risk due to external exposure for the major contaminant of concern $\left({ }^{137} \mathrm{Cs}\right.$ or $\left.{ }^{60} \mathrm{Co}\right)$ at the areas in WAG 2 varies from $5.5 \mathrm{E}-3$ to $2.7 \mathrm{E}-1$, whereas the total risk from all exposure pathways and COCs varies from 3.6E-2 to 4.0E-1 for these same areas. Therefore, the carcinogenic risks associated with the exposure pathways besides the external exposure and produce ingestion pathways have virtually no contribution to the total risk at an area within WAG 2.

The dermal exposure and inhalation pathways never exceed the target risk range at any of the areas. The incidental ingestion pathway, although it accounts for a small percentage of the total risk, exceeds the target risk range at IHP and MMBC. Although it generally presents less risk than the external exposure pathway, the ingestion-of-produce pathway represents a risk in exceedance of the target risk range to a future resident at all of the areas. The risk values for ingestion of produce at the WAG 2 areas vary from 8.7E-4 (UMBC) to 4.0E-1 (MMBC). All of these values exceed the target risk range $(>1.0 \mathrm{E}-4)$ for future residents.

6.4.2.2 Recreational scenario-carcinogenic results. The carcinogenic risks to a future recreational user were determined for exposure to contaminated floodplain soils and sediment through incidental ingestion, dermal contact, inhalation of suspended particulates, and external exposure to radionuclides. Table 7 provides a summary of the risk estimates for the exposure of a recreational user to the WAG 2 carcinogenic COCs in the floodplain soils and sediments. The tables include the individual risk estimates for each exposure pathway and the total risk from all the exposure pathways (sum of the individual exposure pathways). In addition, the contaminant, along with the risk estimate and exposure pathway for this contaminant, which contributes the most to the overall carcinogenic risk is also included in the summary tables. As in the case of the residential land use scenario, total risk to the trespasser is due almost exclusively to external exposure from radionuclides. The contaminants that drive the risk values for external exposure are ${ }^{137} \mathrm{Co}$ and ${ }^{60} \mathrm{Co}$. Cesium-137 is the major contaminant for the IHP, LWOC, MWOC, and $\mathrm{LMBC}$ areas, whereas ${ }^{60} \mathrm{Co}$ is the primary contaminant for the MMBC and UMBC areas. 
Table 6. Summary of carcinogenic risk for WAG 2 sediment on the basis of the residential land use scenario (0-15 cm depth samples)

\begin{tabular}{|c|c|c|c|c|c|c|c|}
\hline Area $^{a}$ & $\begin{array}{c}\text { Ingestion } \\
\text { of } \\
\text { sediment }\end{array}$ & $\begin{array}{l}\text { Ingestion of } \\
\text { produce }\end{array}$ & $\begin{array}{c}\text { Dermal } \\
\text { exposure }\end{array}$ & $\begin{array}{c}\text { Inhalation of } \\
\text { wind-generated } \\
\text { sediment }\end{array}$ & $\begin{array}{l}\text { External } \\
\text { exposure }\end{array}$ & $\begin{array}{c}\text { Total risk from } \\
\text { exposure pathways }\end{array}$ & $\begin{array}{l}\text { Major contaminant, } \\
\text { exposure pathway, and } \\
\text { risk value }\end{array}$ \\
\hline IHP & $3.4 \mathrm{E}-4$ & $6.2 \mathrm{E}-2$ & $1.1 \mathrm{E}-5$ & $3.5 \mathrm{E}-7$ & $2.7 \mathrm{E}-1$ & $3.2 \mathrm{E}-1$ & $\begin{array}{l}\text { Cs-137, external } \\
\text { exposure, } 2.7 \mathrm{E}-1\end{array}$ \\
\hline LWOC & 8.3E-5 & $1.5 \mathrm{E}-2$ & $4.2 \mathrm{E}-6$ & $2.4 \mathrm{E}-7$ & $5.8 \mathrm{E}-2$ & $7.2 \mathrm{E}-2$ & $\begin{array}{l}\text { Cs-137, external } \\
\text { exposure, } 5.2 \mathrm{E}-2\end{array}$ \\
\hline LMBC & $3.2 \mathrm{E}-5$ & $6.4 \mathrm{E}-3$ & & $1.1 \mathrm{E}-7$ & $3.6 \mathrm{E}-2$ & $4.2 \mathrm{E}-2$ & $\begin{array}{l}\text { Cs-137, external } \\
\text { exposure, 3.2E-2 }\end{array}$ \\
\hline MWOC & $4.8 \mathrm{E}-5$ & $7.3 \mathrm{E}-3$ & $1.6 \mathrm{E}-5$ & $8.6 \mathrm{E}-8$ & $2.9 \mathrm{E}-2$ & $3.6 \mathrm{E}-2$ & $\begin{array}{l}\text { Cs-137, external } \\
\text { exposure, } 2.7 \mathrm{E}-2\end{array}$ \\
\hline MMBC & $1.7 \mathrm{E}-3$ & $4.0 \mathrm{E}-1$ & & $1.6 \mathrm{E}-7$ & $5.5 \mathrm{E}-3$ & $4.1 \mathrm{E}-1$ & $\begin{array}{c}\text { Sr-90, produce, } \\
4.0 \mathrm{E}-1\end{array}$ \\
\hline UMBC & $4.6 \mathrm{E}-6$ & 8.7E-4 & & $1.9 \mathrm{E}-7$ & $4.3 \mathrm{E}-2$ & $4.3 \mathrm{E}-2$ & $\begin{array}{l}\text { Co-60, external } \\
\text { exposure, } 4.3 \mathrm{E}-2\end{array}$ \\
\hline
\end{tabular}

${ }^{a} \mathrm{IHP}=$ Intermediate Holding Pond; LMBC = Lower Melton Branch Creek; LWOC = Lower White Oak Creek; MMBC = Middle Melton Branch Creek; MWOC $=$ Middle White Oak Creek; UMBC $=$ Upper Melton Branch Creek. 
Table 7. Summary of carcinogenic risk for WAG 2 sediment on the basis of the recreational land use scenario (0-15 cm depth samples)

\begin{tabular}{ccccccc}
\hline Area $^{a}$ & $\begin{array}{c}\text { Ingestion of } \\
\text { sediment }\end{array}$ & $\begin{array}{c}\text { Dermal } \\
\text { exposure }\end{array}$ & $\begin{array}{c}\text { Inhalation of } \\
\text { wind-generated } \\
\text { sediment }\end{array}$ & $\begin{array}{c}\text { External } \\
\text { exposure }\end{array}$ & $\begin{array}{c}\text { Total risk from } \\
\text { exposure } \\
\text { pathways }\end{array}$ & $\begin{array}{c}\text { Major contaminant, } \\
\text { exposure pathway, } \\
\text { and risk value }\end{array}$ \\
\hline IHP & $3.1 \mathrm{E}-6$ & $2.3 \mathrm{E}-6$ & $3.1 \mathrm{E}-9$ & $2.8 \mathrm{E}-3$ & $2.8 \mathrm{E}-3$ & $\begin{array}{c}\text { Cs-137, external } \\
\text { exposure, } 2.8 \mathrm{E}-3\end{array}$ \\
LWOC & $7.4 \mathrm{E}-7$ & $8.9 \mathrm{E}-7$ & $2.2 \mathrm{E}-9$ & $5.4 \mathrm{E}-4$ & $5.4 \mathrm{E}-4$ & $\begin{array}{c}\text { Cs-137, external } \\
\text { exposure, } 4.7 \mathrm{E}-4\end{array}$ \\
LMBC & $2.8 \mathrm{E}-7$ & & & & $3.3 \mathrm{E}-4$ & Cs-137, external \\
exposure, 2.9E-4
\end{tabular}

${ }^{a} \mathrm{IHP}=$ Intermediate Holding Pond; LMBC = Lower Melton Branch Creek; LWOC = Lower White Oak Creek; MMBC = Middle Melton Branch Creek; MWOC $=$ Middle White Oak Creek; UMBC = Upper Melton Branch Creek. 
In every area the total carcinogenic risk is due primarily to either ${ }^{137} \mathrm{Co}$ or ${ }^{60} \mathrm{Co}$ through the external exposure pathway. For example, the risk from external exposure for the major contaminant of concern $\left({ }^{137} \mathrm{Co}\right.$ or $\left.{ }^{60} \mathrm{Co}\right)$ at the areas in WAG 2 varies from $4.9 \mathrm{E}-5$ to $2.8 \mathrm{E}-3$, whereas the total risk from all exposure pathways and COCs varies from $6.4 \mathrm{E}-5$ to $2.8 \mathrm{E}-3$ for these same areas. Therefore, the carcinogenic risks associated with exposure pathways other than the external exposure pathway have virtually no contribution to the total risk at an area within WAG 2. The carcinogenic risk is due almost exclusively to either ${ }^{137} \mathrm{Cs}$ or ${ }^{60} \mathrm{Co}$ from the external exposure pathway.

Most of the carcinogenic risk values for the incidental ingestion pathway and all of the risk values for the inhalation pathway for recreational land use are $<1.0 \mathrm{E}-6$ and are therefore of no concern. In addition, dermal contact with floodplain soils and sediment are within the target risk range for areas IHP and MWOC while either $<1.0 \mathrm{E}-6$ or not present in the other areas (due to no detected contaminants that cause dermal contact risk).

6.4.2.3 Industrial scenario-carcinogenic results. The carcinogenic risks to a future industrial worker were determined for exposure to WAG 2 floodplain soils and sediment via incidental ingestion, dermal contact, inhalation of wind-generated dust particulates, and external exposure to radionuclides. Table 8 provides a summary of the risk estimates for the exposure of an industrial worker to the WAG 2 carcinogenic COCs in the floodplain soils and sediment. The table includes the individual risk estimates for each exposure pathway and the total risk from all the exposure pathways. The contaminant, along with the risk estimate and exposure pathway for this contaminant, which has the greatest contribution to the overall carcinogenic risk is also included in the summary tables. As in the case of the other land use scenarios, total risk to the industrial worker is due almost exclusively to the external exposure to radionuclides pathway. The contaminants which drive the risk values for external exposure are ${ }^{137} \mathrm{Cs}$ and ${ }^{60} \mathrm{Co}$. Cesium137 is the major contaminant for the IHP, LWOC, MWOC, and LMBC areas, whereas ${ }^{60} \mathrm{Co}$ is the primary contaminant for the $\mathrm{MMBC}$ and $\mathrm{UMBC}$ areas. The carcinogenic risks associated with exposure pathways other than the extemal exposure pathway have little contribution to the total risk at an area within WAG 2. The carcinogenic risk is due almost exclusively to either ${ }^{137} \mathrm{Cs}$ or ${ }^{60} \mathrm{Co}$ through the external exposure pathway.

Most of the carcinogenic risk values for the ingestion of soil/sediment pathway fall within the range of concern of 1.0E-06 to 1.0E-04. However, the MMBC area shows a risk that exceeds the target risk range for the ingestion of soils/sediment, with a risk values of 4.1E-4. Risk values for the dermal contact and inhalation pathways for the industrial worker are all $<1.0 \mathrm{E}-06$ and therefore, do not present a concern.

6.4.2.4 Summary - carcinogenic results. Table 9 provides a summary of the total carcinogenic risk (sum of all exposure pathways) associated with each land use scenario for all of the areas in WAG 2. The table includes risk values for subsurface (radionuclide results only) and surface data. For the industrial land use scenario, the carcinogenic risk at all of the areas exceed the target risk range since all risk values are $>1.0 \mathrm{E}-4$. All of the risk values for subsurface and surface data for the industrial land use scenario are within an order of magnitude of each other, with the subsurface risk result generally being lower than that of the surface result. This is primarily due to representative concentrations of key radionuclides for the subsurface being lower than that of the surface in addition to the fact that risk results for metals and organic data are only generated for the surface layer. 
Table 8. Summary of carcinogenic risk for WAG 2 sediment on the basis of the industrial land use scenario (0-15 cm depth samples)

\begin{tabular}{|c|c|c|c|c|c|c|}
\hline Area $^{a}$ & $\begin{array}{l}\text { Ingestion of } \\
\text { sediment }\end{array}$ & $\begin{array}{c}\text { Dermal } \\
\text { exposure }\end{array}$ & $\begin{array}{c}\text { Inhalation of } \\
\text { wind-generated } \\
\text { sediment }\end{array}$ & $\begin{array}{l}\text { External } \\
\text { exposure }\end{array}$ & $\begin{array}{c}\text { Total risk from } \\
\text { exposure } \\
\text { pathways }\end{array}$ & $\begin{array}{l}\text { Major contaminant, } \\
\text { exposure pathway, and } \\
\text { risk value }\end{array}$ \\
\hline IHP & 8.4E-5 & $3.8 \mathrm{E}-6$ & $2.1 \mathrm{E}-7$ & $6.1 \mathrm{E}-2$ & $6.1 \mathrm{E}-2$ & $\begin{array}{l}\text { Cs-137, external } \\
\text { exposure, } 6.0 \mathrm{E}-1\end{array}$ \\
\hline LWOC & $2.0 \mathrm{E}-5$ & $1.5 \mathrm{E}-6$ & $1.4 \mathrm{E}-7$ & $1.0 \mathrm{E}-2$ & $1.2 \mathrm{E}-2$ & $\begin{array}{l}\text { Cs-137, external } \\
\text { exposure, } 1.0 \mathrm{E}-2\end{array}$ \\
\hline LMBC & $7.9 \mathrm{E}-6$ & & $6.3 \mathrm{E}-8$ & $7.3 \mathrm{E}-3$ & 7.3E-3 & $\begin{array}{l}\text { Cs-137, external } \\
\text { exposure, } 6.5 E-3\end{array}$ \\
\hline MWOC & $9.7 \mathrm{E}-6$ & $5.5 \mathrm{E}-6$ & $5.1 \mathrm{E}-8$ & $5.8 \mathrm{E}-3$ & $5.8 \mathrm{E}-3$ & $\begin{array}{l}\text { Cs-137, external } \\
\text { exposure, } 5.5 E-3\end{array}$ \\
\hline MMBC & $4.1 \mathrm{E}-4$ & & 9.4E-8 & $1.1 \mathrm{E}-3$ & $1.5 \mathrm{E}-3$ & $\begin{array}{l}\text { Co- } 60 \text {, external } \\
\text { exposure, } 9.3 \mathrm{E}-4\end{array}$ \\
\hline UMBC & $1.1 \mathrm{E}-6$ & & $1.1 \mathrm{E}-7$ & $8.6 \mathrm{E}-3$ & $8.6 \mathrm{E}-3$ & $\begin{array}{l}\text { Co- } 60, \text { external } \\
\text { exposure, 8.6E-3 }\end{array}$ \\
\hline
\end{tabular}

${ }^{a} \mathrm{IHP}=$ Intermediate Holding Pond; LMBC = Lower Melton Branch Creek; LWOC = Lower White Oak Creek; MMBC = Middle Melton Branch Creek; MWOC $=$ Middle White Oak Creek; UMBC = Upper Melton Branch Creek. 
Table 9. Summary table of total carcinogenic risk for areas in WAG 2

\begin{tabular}{|c|c|c|c|c|c|c|}
\hline \multirow[b]{2}{*}{ Area $^{a}$} & \multicolumn{2}{|c|}{ Industrial land use } & \multicolumn{2}{|c|}{ Recreational land use } & \multicolumn{2}{|c|}{ Residential land use } \\
\hline & Subsurface $^{b}$ & Surface $^{c}$ & Subsurface $^{b}$ & Surface $^{c}$ & Subsurface $^{b}$ & Surface $^{c}$ \\
\hline IHP & 4.0E-2 & $6.1 \mathrm{E}-2$ & $1.8 \mathrm{E}-3$ & $2.8 \mathrm{E}-3$ & 2.1E-1 & $3.2 \mathrm{E}-1$ \\
\hline LWOC & $1.3 \mathrm{E}-2$ & $1.2 \mathrm{E}-2$ & $5.8 \mathrm{E}-4$ & $5.4 \mathrm{E}-4$ & $7.2 \mathrm{E}-2$ & $7.2 \mathrm{E}-2$ \\
\hline LMBC & $2.4 \mathrm{E}-3$ & 7.3E-3 & $1.1 \mathrm{E}-4$ & 3.3E-4 & $1.3 \mathrm{E}-2$ & $4.2 \mathrm{E}-2$ \\
\hline MWOC & $3.5 \mathrm{E}-4$ & $5.8 \mathrm{E}-3$ & $1.6 \mathrm{E}-5$ & $2.6 \mathrm{E}-4$ & $1.9 \mathrm{E}-3$ & $3.6 \mathrm{E}-2$ \\
\hline MMBC & $2.9 \mathrm{E}-4$ & $1.5 \mathrm{E}-3$ & $1.1 \mathrm{E}-5$ & $6.4 \mathrm{E}-5$ & $3.1 \mathrm{E}-1$ & 4.1E-1 \\
\hline UMBC & $1.3 \mathrm{E}-2$ & 8.6E-3 & $5.7 \mathrm{E}-4$ & $3.9 \mathrm{E}-4$ & $6.3 \mathrm{E}-2$ & $4.3 \mathrm{E}-2$ \\
\hline
\end{tabular}

${ }^{o} \mathrm{IHP}=$ Intermediate Holding Pond; LMBC $=$ Lower Melton Branch Creek; LWOC $=$ Lower White Oak Creek; MMBC = Middle Melton Branch Creek; MWOC $=$ Middle White Oak Creek; UMBC $=$ Upper Melton Branch Creek.

${ }^{b}$ Subsurface $=$ data collected from greater than $15 \mathrm{~cm}$ below the ground surface.

'Surface $=$ data collected from 0 to $15 \mathrm{~cm}$ below the ground surface. 
The surface floodplain soils and sediments in the IHP present the greatest human health risk for future industrial workers, with a risk value of $6.1 \mathrm{E}-2$.

The recreational risk values for the analyzed areas vary from $1.1 \mathrm{E}-5$ to $2.8 \mathrm{E}-3$. The risk values for the subsurface soil/sediment of the MWOC area and the surface and subsurface soil/sediment of the MMBC area fall in the range of concern of $1.0 \mathrm{E}-06$ to $1.0 \mathrm{E}-04$. However, the carcinogenic risk values for all other areas are $>1.0 \mathrm{E}-04$ and therefore, represent high risk to the recreational user. The surface floodplain soils and sediment in the IHP area present the greatest human health risk for the recreational scenario, with a carcinogenic risk value of $1.3 \mathrm{E}-2$.

The residential risk values for the WAG 2 areas vary from 1.9E-3 to 4.1E-1 for the industrial land use scenario. Because these values are greater than $1.0 \mathrm{E}-4$, they represent high risk for the future industrial worker caused by exposure to WAG 2 contaminants. The MMBC area presents the greatest human health risks to potential residents, with a carcinogenic risk value of 4.1E-1.

6.4.2.5 Residential scenario-noncarcinogenic results. The noncarcinogenic human health effects to a future on-WAG resident were determined for exposure to the WAG 2 floodplain soils and sediments through the following exposure pathways: ingestion of by a child, ingestion by an adult, ingestion of produce, dermal contact, and inhalation of wind-generated dust particulates. Table 10 provides a summary of HQs for exposure of a future resident to WAG 2 floodplain soil and sediment noncarcinogenic COCs. There is no discrimination between surface and subsurface results since the metal and organic data was not segregated by depth and since radionuclides (which were segregated by depth) do not contribute to noncarcinogenic risk. In addition, the contaminant, along with the HQs and exposure pathway, which has the greatest contribution to the total $\mathrm{HI}$ for an area is provided in Table 10.

Risk results shown in Table 10 reveal that mercury, chromium, and manganese represent the major COCs for noncarcinogenic human health effects to future residents residing on WAG 2. The total HIs for both the child and adult in all areas are greater than unity (1.0) and thus represent a areas of concern for the residential scenario. The ingestion of produce pathway is primarily responsible for the HIs being high for each of the areas. In addition, ingestion by a child receptor produced HQs > 1.0 for the IHP, MMBC, and UMBC areas. Because the hazard quotient for this pathway is greater than 1.0 in these areas, it is also a pathway of concern for the child receptor in the residential land use scenario. Mercury is the major COC for the subsurface data in the IHP, LWOC and MWOC areas. Chromium is the major contaminant responsible for the $\mathrm{HI}$ being $>1.0$ for the $\mathrm{LMBC}$ area, whereas manganese is the COC for the MMBC and UMBC areas.

6.4.2.6 Recreational scenario-noncarcinogenic results. The noncarcinogenic human health effects to a future on-WAG recreational user were determined for exposure to the WAG 2 floodplain soils and sediment through the following exposure pathways: ingestion by a child, ingestion by an adult, dermal contact, and inhalation of wind-generated dust and particulates. Table 11 provides a summary of the HQs for exposure of a future recreational user to WAG 2 floodplain soil and sediment noncarcinogenic contaminants. The table lists the HQs for the exposure pathways and total HIs from each area and also provides the contaminant, along with the HQ and exposure pathway, which has the greatest contribution to the total $\mathrm{HI}$ for an area. The HQs and total HIs for all of the areas are $<1.0$. 
Table 10. Summary of hazard quotients for noncarcinogenic effects for WAG 2 sediment on the basis of the residential land use scenario (0-15 $\mathrm{cm}$ depth samples)

\begin{tabular}{|c|c|c|c|c|c|c|c|c|}
\hline \multirow[b]{2}{*}{ Area $^{a}$} & \multicolumn{2}{|c|}{ Ingestion of sediment } & \multirow[b]{2}{*}{$\begin{array}{l}\text { Ingestion of } \\
\text { produce }\end{array}$} & \multirow[b]{2}{*}{$\begin{array}{c}\text { Dermal } \\
\text { exposure }\end{array}$} & \multirow[b]{2}{*}{$\begin{array}{c}\text { Inhalation of } \\
\text { wind-generated } \\
\text { sediment }\end{array}$} & \multicolumn{2}{|c|}{ Total hazard index } & \multirow[b]{2}{*}{$\begin{array}{l}\text { Major contaminant, } \\
\text { exposure pathway, and } \\
\text { hazard quotient }\end{array}$} \\
\hline & Adult & Child & & & & Adult & Child & \\
\hline IHP & $2.5 \mathrm{E}-1$ & $2.3 \mathrm{E}+0$ & $9.0 \mathrm{E}+1$ & $3.9 \mathrm{E}-1$ & $6.0 \mathrm{E}-3$ & $9.1 \mathrm{E}+1$ & $9.3 \mathrm{E}+1$ & $\begin{array}{l}\text { Mercury, ingestion } \\
\text { of produce, } 7.0 \mathrm{E}+1\end{array}$ \\
\hline LWOC & $3.8 \mathrm{E}-2$ & $3.6 \mathrm{E}-1$ & $1.1 \mathrm{E}+1$ & $7.4 \mathrm{E}-2$ & 2.3E-6 & $1.1 \mathrm{E}+1$ & $1.2 \mathrm{E}+1$ & $\begin{array}{l}\text { Mercury, ingestion } \\
\text { of produce, } 6.3 \mathrm{E}+0\end{array}$ \\
\hline LMBC & $2.5 \mathrm{E}-2$ & $2.4 \mathrm{E}-1$ & $5.3 \mathrm{E}+0$ & $6.7 \mathrm{E}-2$ & - & $5.4 \mathrm{E}+0$ & $5.6 \mathrm{E}+0$ & $\begin{array}{c}\text { Chromium, ingestion } \\
\text { of produce, } 5.3 \mathrm{E}+0\end{array}$ \\
\hline MWOC & $3.1 \mathrm{E}-2$ & $2.9 \mathrm{E}-1$ & $1.1 \mathrm{E}+1$ & $4.7 \mathrm{E}-2$ & $3.0 \mathrm{E}-6$ & $1.0 \mathrm{E}+1$ & $1.1 \mathrm{E}+1$ & $\begin{array}{l}\text { Mercury, ingestion } \\
\text { of produce, } 8.3 \mathrm{E}+0\end{array}$ \\
\hline MMBC & $1.3 \mathrm{E}-1$ & $1.2 \mathrm{E}+0$ & $3.2 \mathrm{E}+1$ & $2.4 \mathrm{E}-1$ & $3.7 \mathrm{E}-2$ & $3.2 \mathrm{E}+1$ & $3.3 \mathrm{E}+1$ & $\begin{array}{c}\text { Manganese, ingestion } \\
\text { of produce, } 2.1 \mathrm{E}+1\end{array}$ \\
\hline UMBC & $1.5 \mathrm{E}-1$ & $1.4 \mathrm{E}+0$ & $3.5 \mathrm{E}+1$ & $2.4 \mathrm{E}-1$ & $3.8 \mathrm{E}-2$ & $3.5 \mathrm{E}+1$ & $3.7 \mathrm{E}+1$ & $\begin{array}{c}\text { Manganese, ingestion } \\
\text { of produce, } 2.1 \mathrm{E}+1\end{array}$ \\
\hline
\end{tabular}

${ }^{a} \mathrm{IHP}=$ Intermediate Holding Pond; LMBC = Lower Melton Branch Creek; LWOC = Lower White Oak Creek; MMBC = Middle Melton Branch Creek; MWOC $=$ Middle White Oak Creek; UMBC $=$ Upper Melton Branch Creek. 
Table 11. Summary of hazard quotients for noncarcinogenic effects for WAG 2 sediment on the basis of the recreational land use scenario (0-15 $\mathrm{cm}$ depth samples)

\begin{tabular}{|c|c|c|c|c|c|c|c|}
\hline \multirow[b]{2}{*}{ Area $^{a}$} & \multicolumn{2}{|c|}{ Ingestion of sediment } & \multirow[b]{2}{*}{$\begin{array}{c}\text { Dermal } \\
\text { exposure }\end{array}$} & \multirow[b]{2}{*}{$\begin{array}{c}\text { Inhalation of } \\
\text { wind-generated } \\
\text { sediment }\end{array}$} & \multicolumn{2}{|c|}{ Total hazard index } & \multirow[b]{2}{*}{$\begin{array}{l}\text { Major contaminant, } \\
\text { exposure pathway, and } \\
\text { hazard quotient }\end{array}$} \\
\hline & Adult & Child & & & Adult & Child & \\
\hline IHP & $2.2 \mathrm{E}-3$ & $2.1 \mathrm{E}-2$ & 8.4E-2 & $5.4 \mathrm{E}-5$ & 8.6E-2 & $1.0 \mathrm{E}-1$ & $\begin{array}{l}\text { Aroclor- } 1254, \text { dermal } \\
\text { contact, } 4.5 \mathrm{E}-2\end{array}$ \\
\hline LWOC & $3.4 \mathrm{E}-4$ & $3.2 \mathrm{E}-3$ & $1.6 \mathrm{E}-2$ & $2.1 \mathrm{E}-8$ & $1.6 \mathrm{E}-2$ & $1.9 \mathrm{E}-2$ & $\begin{array}{c}\text { Chromium, dermal } \\
\text { contact, } 1.4 \mathrm{E}-2\end{array}$ \\
\hline LMBC & $2.3 \mathrm{E}-4$ & $2.1 \mathrm{E}-3$ & $1.4 \mathrm{E}-2$ & & $1.5 \mathrm{E}-2$ & 1.7E-2 & $\begin{array}{l}\text { Chromium, dermal } \\
\text { contact, 1.4E-2 }\end{array}$ \\
\hline MWOC & $2.8 \mathrm{E}-4$ & $2.6 \mathrm{E}-3$ & $1.0 \mathrm{E}-2$ & 2.7E-8 & $1.0 \mathrm{E}-2$ & $1.3 \mathrm{E}-2$ & $\begin{array}{l}\text { Chromium, dermal } \\
\text { contact, } 7.0 \mathrm{E}-3\end{array}$ \\
\hline MMBC & $1.2 \mathrm{E}-3$ & $1.1 \mathrm{E}-2$ & $5.1 \mathrm{E}-2$ & $3.3 \mathrm{E}-4$ & $5.2 \mathrm{E}-2$ & $6.2 \mathrm{E}-2$ & $\begin{array}{c}\text { Manganese, dermal } \\
\text { contact, } 2.3 \mathrm{E}-2\end{array}$ \\
\hline UMBC & $1.3 \mathrm{E}-3$ & $1.2 \mathrm{E}-2$ & $5.2 \mathrm{E}-2$ & $3.4 \mathrm{E}-4$ & $5.4 \mathrm{E}-2$ & $6.5 \mathrm{E}-2$ & $\begin{array}{l}\text { Chromium, dermal } \\
\text { contact, } 2.6 \mathrm{E}-2\end{array}$ \\
\hline
\end{tabular}

${ }^{a} \mathrm{IHP}=$ Intermediate Holding Pond; LMBC = Lower Melton Branch Creek; LWOC = Lower White Oak Creek; MMBC = Middle Melton Branch Creek; MWOC $=$ Middle White Oak Creek; UMBC $=$ Upper Melton Branch Creek. 
Therefore, no contaminants of concern were identified for therecreational scenario, and total noncarcinogenic human health effects to the future recreational user are of no concern.

6.4.2.7 Industrial scenario - noncarcinogenic results. The noncarcinogenic human health effects to a future industrial worker were determined for exposure to the WAG 2 floodplain soils and sediments via the following exposure pathways: incidental ingestion, dermal contact, and inhalation of wind-generated dust and particulates. Table 12 provides a summary of the hazard quotients for exposure of a future recreational user to WAG 2 contaminants and lists the HQs and total HIs for floodplain soil and sediment data from each area. In addition, the contaminant, along with the HQ and exposure pathway, which has the greatest contribution to the total HI for an area are provided.

None of the individual HQs exceeded 0.1. Therefore, no contaminants of concern were identified for the industrial land use scenario. Total hazard indices for all of the areas are less than 1.0, and therefore, do not represent a concern to the industrial worker for noncarcinogenic human health effects.

6.4.2.8 Summary - noncarcinogenic results. Table 13 provides a summary of the HIs for residential, recreational, and industrial land use scenarios on the basis of the WAG 2 characterization data. The table shows that all of the areas exceed a noncarcinogenic HI of 1.0 for the adult and child exposure scenarios for the residential scenario while non of the areas present a concern based on the recreational and industrial scenarios.

6.4.2.9 External exposure. In addition to the concentration-based risk results presented in the above subsections, risk results based on the USRADS walkover data and the HEDOSE model output were also generated. Table 14 provides a summary comparison for the three methods for the residential scenario.

The concentration-based results are those presented earlier for the upper $15 \mathrm{~cm}$ of floodplain soil and sediment in each of the areas. These results are considered the least indicative of the actual risk that would be experienced for the residential scenario. This is due to three primary factors: a bias in the location of the samples, the fact that the calculation of the concentration term does not account for the shielding provided by depth (and due to water cover over sediment in certain areas), and the inability of this method to account for shine. The results of all six areas for ${ }^{60} \mathrm{Co}$ and ${ }^{137} \mathrm{Cs}$ exceed the target risk range except for ${ }^{137} \mathrm{Cs}$ in UMBC (which was not detected).

The results obtained from the HEDOSE model fix one of the problems with the concentration-based method by accounting for the importance of depth. This is accomplished by calculating the effective dose rate by summing a series of plane sources at a number of different depths. This effective dose rate is then converted to a risk result. However, this method still suffers from the bias present in the location of the soil samples, in particular, the high proportion of samples collected in the weir pools of LMBC and MWOC. The sampling of IHP, MMBC, and $L W O C$ can be considered more representative of the potential exposures but still lack a random design and UMBC has only three samples upon which to base an exposure estimate. The results show that IHP, MWOC, and LWOC, basically the entire WOC main tributary south of WAG 1, exceed the target risk range for ${ }^{137} \mathrm{Cs}$. The middle of the Melton Branch area, $\mathrm{MMBC}$, exceed the target risk range for ${ }^{60} \mathrm{Co}$. 
Table 12. Summary of hazard quotients for noncarcinogenic effects for WAG 2 sediment on the basis of the industrial land use scenario (0-15 cm depth samples)

\begin{tabular}{cccccc}
\hline Area $^{a}$ & $\begin{array}{c}\text { Ingestion of } \\
\text { sediment }\end{array}$ & $\begin{array}{c}\text { Dermal } \\
\text { exposure }\end{array}$ & $\begin{array}{c}\text { Inhalation of wind- } \\
\text { generated sediment }\end{array}$ & $\begin{array}{c}\text { Total hazard } \\
\text { index }\end{array}$ & $\begin{array}{c}\text { Major contaminant, exposure } \\
\text { pathway, and hazard quotient }\end{array}$ \\
\hline IHP & $8.9 \mathrm{E}-2$ & $1.7 \mathrm{E}-1$ & $4.3 \mathrm{E}-3$ & $2.6 \mathrm{E}-1$ & $\begin{array}{c}\text { Aroclor-1254, dermal } \\
\text { contact, } 9.0 \mathrm{E}-2\end{array}$ \\
LWOC & $1.4 \mathrm{E}-2$ & $3.2 \mathrm{E}-2$ & $1.7 \mathrm{E}-6$ & $4.5 \mathrm{E}-2$ & $\begin{array}{c}\text { Chromium, dermal } \\
\text { contact, } 2.7 \mathrm{E}-2\end{array}$ \\
LMBC & $9.1 \mathrm{E}-3$ & $2.9 \mathrm{E}-2$ & - & $3.8 \mathrm{E}-2$ & $\begin{array}{c}\text { Chromium, dermal } \\
\text { contact, 2.9E-2 } \\
\text { Chromium, dermal } \\
\text { contact, } 1.4 \mathrm{E}-2\end{array}$ \\
MWOC & $1.1 \mathrm{E}-2$ & $2.0 \mathrm{E}-2$ & $2.2 \mathrm{E}-6$ & $3.1 \mathrm{E}-2$ & $\begin{array}{c}\text { Manganese, dermal } \\
\text { contact, }\end{array}$ \\
MMBC & $4.5 \mathrm{E}-2$ & $2.6 \mathrm{E}-2$ & $1.7 \mathrm{E}-1$ & $\begin{array}{c}\text { Chromium, dermal } \\
\text { contact, } 5.2 \mathrm{E}-2\end{array}$ \\
\hline
\end{tabular}

ףIHP = Intermediate Holding Pond; LMBC $=$ Lower Melton Branch Creek; LWOC $=$ Lower White Oak Creek; MMBC $=$ Middle Melton Branch Creek; MWOC $=$ Middle White Oak Creek; UMBC $=$ Upper Melton Branch Creek. 
Table 13. Summary of hazard indices for noncarcinogenic effects for WAG 2 areas

\begin{tabular}{|c|c|c|c|c|c|}
\hline \multirow[b]{2}{*}{ Area $^{a}$} & \multicolumn{2}{|c|}{ Residential land use } & \multicolumn{2}{|c|}{ Recreational land use } & \multirow{2}{*}{$\frac{\text { Industrial land use }}{\text { Adult }^{b}}$} \\
\hline & Adult & Child & Adult & Child & \\
\hline IHP & $9.1 \mathrm{E}+1$ & $9.3 \mathrm{E}+1$ & $8.6 \mathrm{E}-2$ & $1.0 \mathrm{E}-1$ & $2.6 \mathrm{E}-1$ \\
\hline LWOC & $1.1 \mathrm{E}+1$ & $1.2 \mathrm{E}+1$ & $1.6 \mathrm{E}-2$ & $1.9 \mathrm{E}-2$ & $4.5 \mathrm{E}-2$ \\
\hline LMBC & $5.4 \mathrm{E}+0$ & $5.6 \mathrm{E}+0$ & $1.5 \mathrm{E}-2$ & $1.7 \mathrm{E}-2$ & $3.8 \mathrm{E}-2$ \\
\hline MWOC & $1.1 \mathrm{E}+1$ & $1.1 \mathrm{E}+1$ & $1.0 \mathrm{E}-2$ & $1.3 \mathrm{E}-2$ & $3.1 \mathrm{E}-2$ \\
\hline $\mathrm{MMBC}$ & $3.2 \mathrm{E}+1$ & $3.3 \mathrm{E}+1$ & $5.2 \mathrm{E}-2$ & $6.2 \mathrm{E}-2$ & $1.7 \mathrm{E}-1$ \\
\hline UMBC & $3.5 \mathrm{E}+1$ & $3.7 \mathrm{E}+1$ & $5.4 \mathrm{E}-2$ & $6.5 \mathrm{E}-2$ & $1.8 \mathrm{E}-1$ \\
\hline
\end{tabular}

IHP = Intermediate Holding Pond; LMBC = Lower Melton Branch Creek; LWOC = Lower White Oak Creek; $\mathrm{MMBC}=$ Middle Melton Branch Creek; MWOC $=$ Middle White Oak Creek; UMBC $=$ Upper Melton Branch Creek.

${ }^{b}$ Because children are not generally allowed on industrial sites, this category of risk is not subdivided between adults and children. 
Table 14. Comparison of external exposure risk based on USRADS ${ }^{a}$ walkover data, HEDOSE model output, and measured soil-sediment core concentrations"

\begin{tabular}{cccccc}
\hline & & \multicolumn{2}{c}{ HEDOSE model } & \multicolumn{2}{c}{ Core } \\
\cline { 3 - 5 } Area $^{b}$ & USRADS & ${ }^{60} \mathrm{Co}$ & ${ }^{137} \mathrm{Cs}$ & ${ }^{60} \mathrm{Co}$ & ${ }^{137} \mathrm{Cs}$ \\
\hline IHP & $4.8 \mathrm{E}-1$ & $2.7 \mathrm{E}-6$ & $2.6 \mathrm{E}-3$ & $3.1 \mathrm{E}-3$ & $2.7 \mathrm{E}-1$ \\
MWOC & $1.3 \mathrm{E}-1$ & $5.8 \mathrm{E}-7$ & $1.1 \mathrm{E}-4$ & $1.3 \mathrm{E}-4$ & $2.7 \mathrm{E}-2$ \\
LWOC & $1.8 \mathrm{E}-1$ & $3.5 \mathrm{E}-6$ & $2.2 \mathrm{E}-3$ & $6.9 \mathrm{E}-3$ & $5.2 \mathrm{E}-2$ \\
UMBC & $8.2 \mathrm{E}-3$ & $2.6 \mathrm{E}-5$ & $1.0 \mathrm{E}-7$ & $6.2 \mathrm{E}-2$ & - \\
MMBC & $6.7 \mathrm{E}-3$ & $1.4 \mathrm{E}-4$ & $9.9 \mathrm{E}-7$ & $4.7 \mathrm{E}-3$ & $7.5 \mathrm{E}-4$ \\
LMBC & $3.7 \mathrm{E}-2$ & $2.8 \mathrm{E}-6$ & $3.5 \mathrm{E}-5$ & $4.1 \mathrm{E}-3$ & $3.2 \mathrm{E}-2$ \\
\hline
\end{tabular}

थSRADS = Ultra Sonic Ranging and Data System.

${ }^{b} \mathrm{IHP}=$ Intermediate Holding Pond; LMBC = Lower Melton Branch Creek; LWOC $=$ Lower White Oak Creek; $M M B C=$ Middle Melton Branch Creek; MWOC = Middle White Oak Creek; UMBC = Upper Melton Branch Creek. 
The USRADS walkover data is the most reliable dataset of the three for calculating the actual exposures at the sites. It is well representative in terms of the number and location of the samples with over 324,000 measurements and it implicitly incorporates the effects of depth and shine. However, there is concern about overcounting due to scattering (DOE 1995), possibly up to 4-5 times the actual dose rate (Sect. 5). It is also not possible to individually discriminate the gamma energies due to ${ }^{60} \mathrm{Co}$ and ${ }^{137} \mathrm{Cs}$ in the USRADS dataset so the total risk from gamma is given in Table 14. The results show that all areas exceed the target risk range with IHP having the highest risk at $4.8 \mathrm{E}-1$. The external exposure pathway is still a problem in this range even if the overcounting factor of 4-5 due to scattering is incorporated.

6.4.2.10 Summary results of WAG 2 assessment. The contaminants that exceed the target carcinogenic risk range risk ( $>1.0 \mathrm{E}-4)$ due to exposure to WAG 2 floodplain soils for the industrial and recreational land use scenarios are primarily ${ }^{137} \mathrm{Cs}$ or ${ }^{60} \mathrm{Co}$, via the external exposure to radionuclides pathway. For the residential land use scenario, which is based on more conservative assumptions, the contaminants of primary concern (risk values exceeding 1.0E-04) included ${ }^{137} \mathrm{Cs},{ }^{60} \mathrm{Co},{ }^{238} \mathrm{Pu},{ }^{239 / 40} \mathrm{Pu},{ }^{89 / 90} \mathrm{Sr},{ }^{228} \mathrm{Th},{ }^{230} \mathrm{Th},{ }^{233 / 4} \mathrm{U},{ }^{238} \mathrm{U},{ }^{241} \mathrm{Am}$, aroclor-1254, aroclor-1260, benzo(a)pyrene, dibenz $(\mathrm{a}, \mathrm{h})$ anthracene, and ${ }^{244} \mathrm{Cm}$. The exposure pathways responsible for risk values exceeding $1.0 \mathrm{E}-4$ for these contaminants include external exposure to radionuclides, ingestion of produce, and incidental ingestion.

No contaminants for the industrial and recreational land use scenarios were identified as being a concern for noncarcinogenic human health effects. However, for the residential land use scenario, the contaminants of primary concern (with a hazard quotient exceeding 1.0) include manganese, mercury, aroclor-1254, chromium, antimony, barium, and nickel, primarily via the ingestion of produce exposure pathway. Representative concentrations and a full accounting of the risk results for all carcinogenic and noncarcinogenic contaminants can be found in Purucker and Douthat (1996). 


\section{SUMMARY AND CONCLUSIONS}

The summary and conclusions for this report are provided in bulletized form, arranged according to the organization of the report.

\subsection{CONTAMINANT CHARACTERIZATION}

- The primary contaminants in the WAG 2 floodplain area are the gamma-emitting radionuclides ${ }^{137} \mathrm{Cs}$ and ${ }^{60} \mathrm{Co}$, although ${ }^{60} \mathrm{Co}$ activity levels are $\sim 1 / 25$ or less in comparison with those of ${ }^{137} \mathrm{Cs}$.

- No other gamma-emitting radionuclides were detected during gamma-spectometric analysis of soil or sediment core samples.

- Levels of ${ }^{137} \mathrm{Cs}$ were highest in the IHP area, although high levels were also observed in the LWOC reach.

- ${ }^{60} \mathrm{Co}$ activities were highest in Melton Branch, particularly UMBC and MMBC, although these levels were $\sim 1 / 25$ that of ${ }^{137} \mathrm{Cs}$.

- Generally, contaminant levels were highest near the surface sediments, and they decreased with depth toward the bottom.

- Although tendencies were observed in some cases, no general trends in contaminant concentration with distance from the WOC stream channel was observed.

- The beta-emitting radionuclides ${ }^{89990} \mathrm{Sr}$ and ${ }^{99} \mathrm{Tc}$ were predominately detected in MMBC (Seep C) and LWOC, respectively.

- The highest concentrations of the relatively short-lived alpha-emitting radionuclides ${ }^{244} \mathrm{Cm}$, ${ }^{241} \mathrm{Am}$, and ${ }^{238} \mathrm{Pu}$ (all with $\mathrm{t}_{1 / 2}<450$ years) were found in Seep $\mathrm{C}$ of the MMBC and IHP respectively.

- The relative proportions of the remaining alpha-emitting radionuclides (all with $t_{1 / 2}$ from 6.5 $\times 10^{3}$ to $1.1 \times 10^{10}$ years) were predominantly found in the IHP area; however, the highest levels of ${ }^{233 / 234} \mathrm{U}$ were observed in the LWOC.

- Inorganic contaminants discussed in this report were limited to those contributing significantly to human health exposure [Sb, $\mathrm{Ba}, \mathrm{Cr}(\mathrm{IV}), \mathrm{Mn}, \mathrm{Hg}$ and $\mathrm{Ni}]$.

- The distributions of antimony and $\mathrm{Mn}$ reflect natural processes rather than anthropogenic sources.

- The highest levels of $\mathrm{Ba}$ and $\mathrm{Cr}(\mathrm{IV})$ were observed in the Melton Branch weirs; this suggests a source in the Melton Branch watershed. $\mathrm{Cr}(\mathrm{IV})$ levels were significantly higher in MMBC than at other sites in the WAG 2 floodplain. 
- $\mathrm{Hg}$ and $\mathrm{Ni}$ were highest in the IHP, reflecting historic releases of these contaminants from operations at ORNL. No significant differences in $\mathrm{Hg}$ or $\mathrm{Ni}$ concentrations were observed in the WAG 2 floodplain.

\subsection{FLOODPLAIN RADIONUCLIDE INVENTORY}

- Based on core samples, a total inventory of $198.6 \mathrm{Ci}$ of gamma-emitting radionuclides was estimated for the WAG 2 floodplain.

- The largest inventories estimated were found in the IHP, with approximately $125 \mathrm{Ci}$ of ${ }^{137} \mathrm{Cs}, 0.47 \mathrm{Ci}$ of ${ }^{89 / 90} \mathrm{Sr}, 0.32 \mathrm{Ci}$ of ${ }^{60} \mathrm{Co}$, and $0.1 \mathrm{Ci}$ of ${ }^{239 / 240} \mathrm{Pu}$; other radionuclide inventories were estimated at less than $0.1 \mathrm{Ci}$ for the IHP.

- For ${ }^{241} \mathrm{Am},{ }^{244} \mathrm{Cm},{ }^{238} \mathrm{Pu},{ }^{239 / 240} \mathrm{Pu},{ }^{99} \mathrm{Tc},{ }^{228} \mathrm{Th},{ }^{230} \mathrm{Th},{ }^{233 / 234} \mathrm{U}$, and ${ }^{238} \mathrm{U}$, highest inventories were estimated in the LWOC reach; ${ }^{239 / 240} \mathrm{Pu}$ and ${ }^{99} \mathrm{Tc}$ were highest, at $\sim 0.2 \mathrm{Ci}$ each.

\subsection{WALKOVER GAMMA ANALYSIS COMPARISON}

- The walkover gamma survey successfully identified areas of gamma concentrations (hot spots) because the contamination was near the surface (Fig. 4; Appendix B.1).

- On the basis of the gamma calculations generated from core analyses, the walkover data correlate well with the soil concentrations in highly contaminated areas. However, walkover data overestimate the extent of contamination relative to core data near these areas, as a result of gamma-shine (Fig. 15).

- Walkover data are a better indicator of external exposure than are core data because they provide more complete coverage; walkover data also incorporate shine, an important contributor to dose.

- Taken togeather, walkover data and integrated core samples provide a much more coherent image as to the extent of contamination in the WAG 2 floodplain.

- The HEDOSE software program developed to calculate effective dose from core data is of potential benefit for comparing remediation alternatives. HEDOSE could be used, for example, to investigate the consequences of erosion exposing deeper contamination or the benefits of placing a layer of clean soil over the most highly contaminated areas.

\subsection{HUMAN HEALTH EXPOSURE ASSESSMENT}

- The contaminants that exceed the target risk range risk ( $>1.0 \mathrm{E}-04)$ due to exposure to WAG 2 floodplain soils for the industrial and recreational land use scenarios are primarily ${ }^{137} \mathrm{Cs}$ or ${ }^{60} \mathrm{Co}$, via the external exposure to radionuclides pathway. 
- For the residential land use scenario, which is based on more conservative assumptions, the contaminants of primary concern (with a risk $>1.0 \mathrm{E}-04$ ) are ${ }^{137} \mathrm{Cs},{ }^{60} \mathrm{Co},{ }^{239 / 240} \mathrm{Pu},{ }^{89 / 90} \mathrm{Sr}$, ${ }^{228} \mathrm{Th},{ }^{241} \mathrm{Am}$, aroclor- 1260 , and ${ }^{244} \mathrm{Cm}$.

- The exposure pathways primarily responsible for risk $>1.0 \mathrm{E}-04$ for these contaminants include external exposure to radionuclides, ingestion of produce, and ingestion of sediment.

- Few noncarcinogenic contaminants of concern (HQ >0.1) were observed in WAG 2.

- No contaminants for the industrial and recreational land use scenarios fit into the noncarcinogen risk categories (HQ $\geq 0.1$ or 1.0 ) and therefore, do not represent a concern for noncarcinogenic human health effects.

- For the residential land use scenario, the contaminants of primary concern (with HQs $>1.0$ ) include $\mathrm{Mn}, \mathrm{Hg}$, aroclor- $1254, \mathrm{Cr}(\mathrm{IV})$, and $\mathrm{Sb}$, primarily via the ingestion of produce exposure pathway.

- In addition to the preceding contaminants that have HQs $>1.0$, other contaminants of concern with hazard quotients exceeding 0.1 include $\mathrm{Ni}$ and $\mathrm{Ba}$, through the ingestion of produce exposure pathway. 


\section{REFERENCES}

Blaylock, B. G., M. L. Frank, L. A. Hook, F. O. Hoffman, and C. J. Ford. 1993. White Oak Creek Embayment Site Characterization and Contaminant Screening Analysis. ORNL/ER81. Oak Ridge National Laboratory, Oak Ridge, Tenn.

Boston, H. L. (ed.). 1992. Field Sampling and Analysis Plan for the Remedial Investigation of Waste Area Grouping 2 at Oak Ridge National Laboratory, Oak Ridge, Tennessee. ORNL/ER-58\&D1. Oak Ridge National Laboratory, Oak Ridge, Tenn..

Clapp, R. B., J. A. Watts, and A. S. Guth (eds.). 1995. Third annual environmental restoration monitoring and assessment report for FY 1994, Oak Ridge National Laboratory, Oak Ridge, Tennessee. DOE/OR/01-1290\&D2. Oak Ridge National Laboratory, Oak Ridge, Tenn.

Clapp, R. B., Y. S. Bao, T. D. Moore, A. L. Brenkert, S. T. Purucker, D. K. Reece, and B. B. Burgoa. 1996. Waste Area Grouping 2 Phase I Remedial Investigation: Sediment and Cesium-137 Transport Modeling Report. ORNL/ER-367. Oak Ridge National Laboratory, Oak Ridge, Tenn.

Dahlman, R. C., and P. Van Voris. 1976. Cycling of ${ }^{137} \mathrm{Cs}$ in soil and vegitation of a flood plain 30 years after initial contamination. pp. 291-298. In C. E. Cushing, Jr. (ed.), Radioecology and Energy Resources. Dowden, Hutchinson, and Ross, Inc.

Dahlman, R. C., C. T. Garten, Jr., and T. E. Hakonson. 1980. Comparative distribution of plutonium in contaminated ecosystems at Oak Ridge, Tennessee, and Los Alamos, New Mexico. pp. 371-380. In W. C. Hanson (ed.), Transuranic Elements in the Environment. DOE/TIC-22800. National Technical Information Service, Springfield, Virginia.

DOE (U.S. Department of Energy). 1995. Fourth Annual Environmental Restoration Monitoring and Assessment Report (FY 1995), Oak Ridge, Tennessee. DOE/OR/011413\&D1. Oak Ridge National Laboratory, Oak Ridge, Tenn.

DOE (U.S. Department of Energy). 1996. Remedial Investigation/ Feasibility Study of the Clinch River/Poplar Creek Operable Unit. DOE/OR/01-1393/V1\&D3. Oak Ridge National Laboratory, Oak Ridge, Tenn.

Eckerman, K. F., and J. C. Ryman. 1993. External Exposure to Radionuclides in Air, Water, and Soil. Federal Guidance Report No. 12. EPA 402-R-93-081. U.S. Environmental Protection Agency.

EPA (U.S. Environmental Protection Agency). 1989. Risk Assessment Guidance for Superfund. Vol. 1: Human Health Evaluation Manual (Part A). EPA/540/1-89/002. Office of Emergency and Remedial Response, Washington, D.C.

EPA (U.S. Environmental Protection Agency). 1991a. Risk Assessment Guidance for Superfund. Vol. 1: Human Health Evaluation Manual (Part B, Development of Risk-Based Preliminary Remediation Goals). OSWER Directive 9285.7-01B. Office of Emergency and Remedial Response, Washington, D.C. 
EPA (U.S. Environmental Protection Agency). 1991b. Standard Default Factors OSWER Directive 9285.6-03. Office of Emergency and Remedial Response, Washington, D.C.

Kimbrough, C. W. 1990. Environmental Surveillance Procedures Quality Control Program. ESH/Sub/8721706/1. Energy Systems Environmental Restoration Program, Oak Ridge, Tenn.

Kornegay, F. (ed.). 1994. Oak Ridge Reservation Annual Site Environmental Report for 1993. ES/ESH-47. Oak Ridge National Laboratory, Oak Ridge, Tenn.

LMES (Lockheed Martin Energy Systems, Inc.). 1996. Role of Risk Assessment at DOE-ORO. ES/ER/TM-180. Energy Systems Environmental Restoration Program, Oak Ridge, Tenn.

MMES (Martin Marietta Energy Systems, Inc.). 1993. Statement of Work. SOW 118. Energy Systems Environmental Restoration Program, Oak Ridge, Tenn.

Nyquist, J. E., and M. S. Blair. 1991. A geophysical tracking and data logging system:

Description and case history. Geophysics 56:1114-21.

Purucker, S.T., and D. M. Douthat. 1996. Waste Area Grouping 2 Phase I Task Data Report: Human Health Risk Assessment. ORNL/ER-368.

Sherwood, C. B., and J. M. Loar. 1987. Environmental data for the White Oak Creek/White Oak Lake Watershed. ORNL/TM-10062. Oak Ridge National Laboratory, Oak Ridge, Tenn. 


\section{APPENDIX A \\ QUALITY CONTROL DATA FOR INORGANIC, ORGANIC, TRANSURANIC, AND BETA SOIL AND SEDIMENT SAMPLES}


Table A.1. Results of inorganic soil samples submitted for quality control (QC) analysis as part of the WAG 2 floodplain soil and sediment characterization and inventory

\begin{tabular}{|c|c|c|c|c|c|}
\hline Category & Area $^{a}$ & QC type & Date & Analysis & $\begin{array}{c}\text { Result } \\
(\mathrm{mg} / \mathrm{kg})\end{array}$ \\
\hline Blank & LWOC & Field blank & 25APR94 & Aluminum & 49 \\
\hline Blank & LWOC & Field blank & 20SEP94 & Aluminum & 31 \\
\hline Blank & LWOC & Field blank & 25APR94 & Antimony & 34 \\
\hline Blank & LWOC & Field blank & 20SEP94 & Antimony & 46 \\
\hline Blank & LWOC & Field blank & 25APR94 & Arsenic & 3 \\
\hline Blank & LWOC & Field blank & 20SEP94 & Arsenic & 2 \\
\hline Blank & LWOC & Field blank & 25APR94 & Barium & 37 \\
\hline Blank & LWOC & Field blank & 20SEP94 & Barium & 14 \\
\hline Blank & LWOC & Field blank & 25APR94 & Beryllium & 1 \\
\hline Blank & LWOC & Field blank & 20SEP94 & Beryllium & 1 \\
\hline Blank & LWOC & Field blank & 25APR94 & Boron & 25.9 \\
\hline Blank & LWOC & Field blank & 20SEP94 & Boron & 91.6 \\
\hline Blank & LWOC & Field blank & 25APR94 & Cadmium & 4 \\
\hline Blank & LWOC & Field blank & 20SEP94 & Cadmium & 3 \\
\hline Blank & LWOC & Field blank & 25APR94 & Calcium & 171 \\
\hline
\end{tabular}


Table A.1. (continued)

\begin{tabular}{|c|c|c|c|c|c|}
\hline Category & Area $^{a}$ & QC type & Date & Analysis & $\begin{array}{c}\text { Result } \\
(\mathrm{mg} / \mathrm{kg})\end{array}$ \\
\hline Blank & LWOC & Field blank & 20SEP94 & Calcium & 58.3 \\
\hline Blank & LWOC & Field blank & 25APR94 & Chromium & 5 \\
\hline Blank & LWOC & Field blank & 20SEP94 & Chromium & 4.2 \\
\hline Blank & LWOC & Field blank & 25APR94 & Cobalt & 11 \\
\hline Blank & LWOC & Field blank & 20SEP94 & Cobalt & 8 \\
\hline Blank & LWOC & Field blank & 25APR94 & Copper & 14 \\
\hline Blank & LWOC & Field blank & 20SEP94 & Copper & 2 \\
\hline Blank & LWOC & Field blank & 25APR94 & Iron & 25.5 \\
\hline Blank & LWOC & Field blank & 20SEP94 & Iron & 23.8 \\
\hline Blank & LWÖC & Field blank & 25APR94 & Lead & 2 \\
\hline Blank & LWOC & Field blank & 20SEP94 & Lead & 2 \\
\hline Blank & LWOC & Field blank & 25APR94 & Lithium & 33 \\
\hline Blank & LWOC & Field blank & 20SEP94 & Lithium & 11 \\
\hline Blank & LWOC & Field blank & 25APR94 & Magnesium & 89 \\
\hline Blank & LWOC & Field blank & 20SEP94 & Magnesium & 48 \\
\hline Blank & LWOC & Field blank & 25APR94 & Manganese & 3.4 \\
\hline Blank & LWOC & Field blank & 20SEP94 & Manganese & 2 \\
\hline
\end{tabular}


Table A.1 (continued)

\begin{tabular}{|c|c|c|c|c|c|}
\hline Category & Area $^{a}$ & QC type & Date & Analysis & $\begin{array}{c}\text { Result } \\
(\mathrm{mg} / \mathrm{kg}) \\
\end{array}$ \\
\hline Blank & LWOC & Field blank & 25APR94 & Mercury & 0.2 \\
\hline Blank & LWOC & Field blank & 25APR94 & Molybdenum & 26 \\
\hline Blank & LWOC & Field blank & 20SEP94 & Molybdenum & 14 \\
\hline Blank & LWOC & Field blank & 20SEP94 & Nickel & 8 \\
\hline Blank & LWOC & Field blank & 25APR94 & Osmium & 24 \\
\hline Blank & LWOC & Field blank & 20SEP94 & Osmium & 27 \\
\hline Blank & LWOC & Field blank & 25APR94 & Potassium & 483 \\
\hline Blank & LWOC & Field blank & 20SEP94 & Selenium & 3 \\
\hline Blank & LWOC & Field blank & 25APR94 & Silicon & 172 \\
\hline Blank & LWOC & Field blank & 20SEP94 & Silicon & 166 \\
\hline Blank & LWOC & Field blank & 25APR94 & Silver & 5 \\
\hline Blank & LWOC & Field blank & 20SEP94 & Silver & 4 \\
\hline Blank & LWOC & Field blank & 25APR94 & Sodium & 156 \\
\hline
\end{tabular}


Table A.1 (continued)

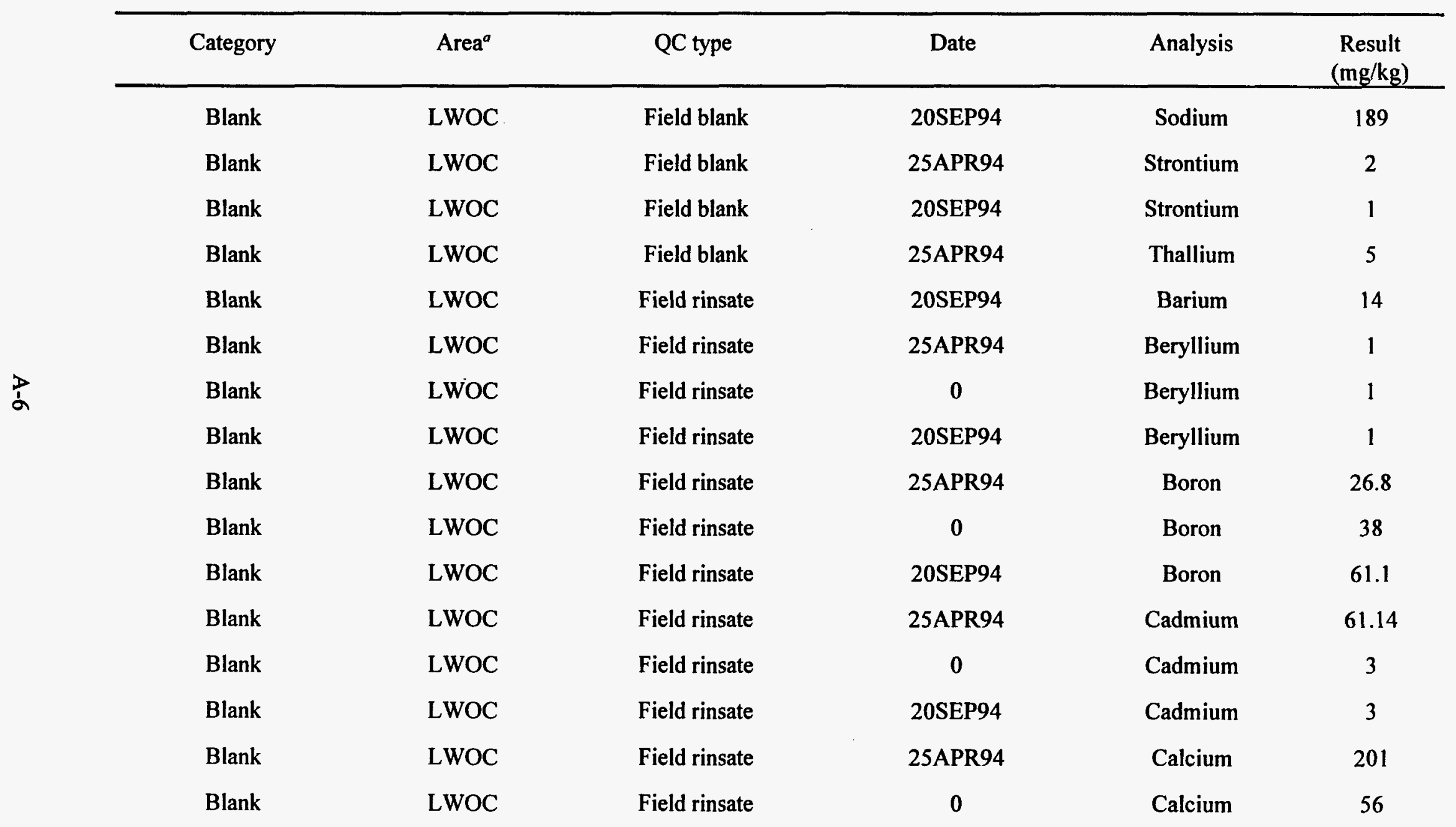


Table A.1 (continued)

\begin{tabular}{|c|c|c|c|c|c|}
\hline Category & Area $^{a}$ & QC type & Date & Analysis & $\begin{array}{c}\text { Result } \\
(\mathrm{mg} / \mathrm{kg})\end{array}$ \\
\hline Blank & LWOC & Field rinsate & 20SEP94 & Calcium & 90.3 \\
\hline Blank & LWOC & Field rinsate & 25APR94 & Chromium & 5 \\
\hline Blank & LWOC & Field rinsate & 0 & Chromium & 11.6 \\
\hline Blank & LWOC & Field rinsate & 20SEP94 & Chromium & 4 \\
\hline Blank & LWOC & Field rinsate & 25APR94 & Cobalt & 11 \\
\hline Blank & LWOC & Field rinsate & 0 & Cobalt & 8 \\
\hline Blank & LWOC & Field rinsate & 20SEP94 & Cobalt & 8 \\
\hline Blank & LWOC & Field rinsate & 25APR94 & Copper & 14.5 \\
\hline Blank & LWOC & Field rinsate & 0 & Copper & 2 \\
\hline Blank & LWOC & Field rinsate & 20SEP94 & Copper & 4 \\
\hline Blank & LWOC & Field rinsate & 25APR94 & Iron & 18 \\
\hline Blank & LWOC & Field rinsate & 0 & Iron & 257 \\
\hline Blank & LWOC & Field rinsate & 20SEP94 & Iron & 75.4 \\
\hline Blank & LWOC & Field rinsate & 25APR94 & Lead & 2 \\
\hline Blank & LWOC & Field rinsate & 0 & Lead & 2 \\
\hline Blank & LWOC & Field rinsate & 20SEP94 & Lead & 2 \\
\hline Blank & LWOC & Field rinsate & 25APR94 & Lithium & 33 \\
\hline
\end{tabular}


Table A.1 (continued)

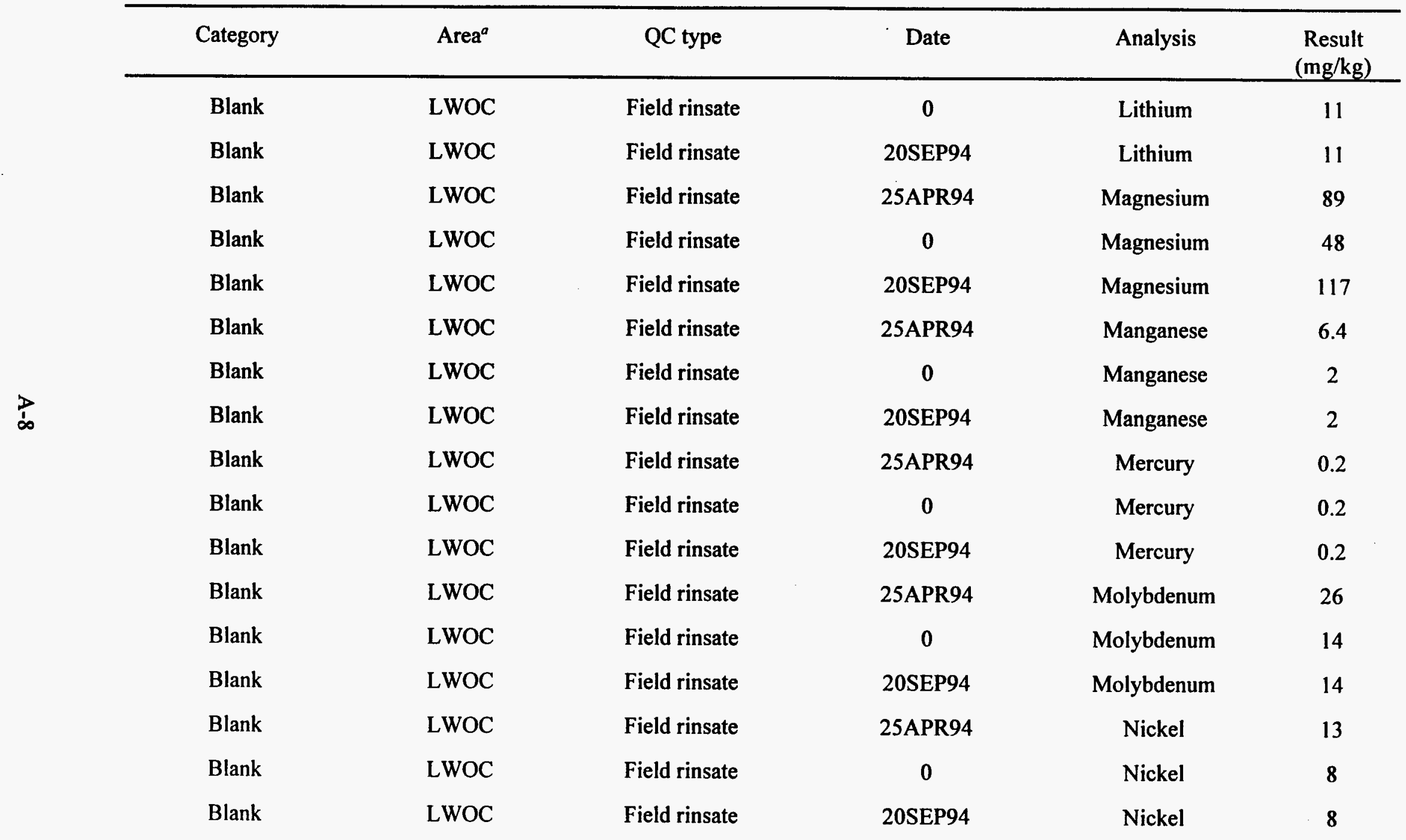


Table A.1. (continued)

\begin{tabular}{|c|c|c|c|c|c|}
\hline Category & Area $^{a}$ & QC type & Date & Analysis & $\begin{array}{c}\text { Result } \\
(\mathrm{mg} / \mathrm{kg})\end{array}$ \\
\hline Blank & LWOC & Field rinsate & 25APR94 & Osmium & 24 \\
\hline Blank & LWOC & Field rinsate & 0 & Osmium & 41.4 \\
\hline Blank & LWOC & Field rinsate & 20SEP94 & Osmium & 27 \\
\hline Blank & LWOC & Field rinsate & 25APR94 & Potassium & 483 \\
\hline Blank & LWOC & Field rinsate & 0 & Potassium & 364 \\
\hline Blank & LWOC & Field rinsate & 20SEP94 & Potassium & 363 \\
\hline Blank & LWOC & Field rinsate & 25APR94 & Selenium & 3 \\
\hline Blank & LWOC & Field rinsate & 0 & Selenium & 3 \\
\hline Blank & LWOC & Field rinsate & 20SEP94 & Selenium & 3 \\
\hline Blank & LWOC & Field rinsate & 25APR94 & Silicon & 111 \\
\hline Blank & LWOC & Field rinsate & 0 & Silicon & 219 \\
\hline Blank & LWOC & Field rinsate & 20SEP94 & Silicon & 236 \\
\hline Blank & LWOC & Field rinsate & 25APR94 & Silver & 5 \\
\hline Blank & LWOC & Field rinsate & 0 & Silver & 4 \\
\hline Blank & LWOC & Field rinsate & 20SEP94 & Silver & 4 \\
\hline Blank & LWOC & Field rinsate & 25APR94 & Sodium & 137 \\
\hline Blank & LWOC & Field rinsate & 0 & Sodium & 55.9 \\
\hline
\end{tabular}


Table A.1 (continued)

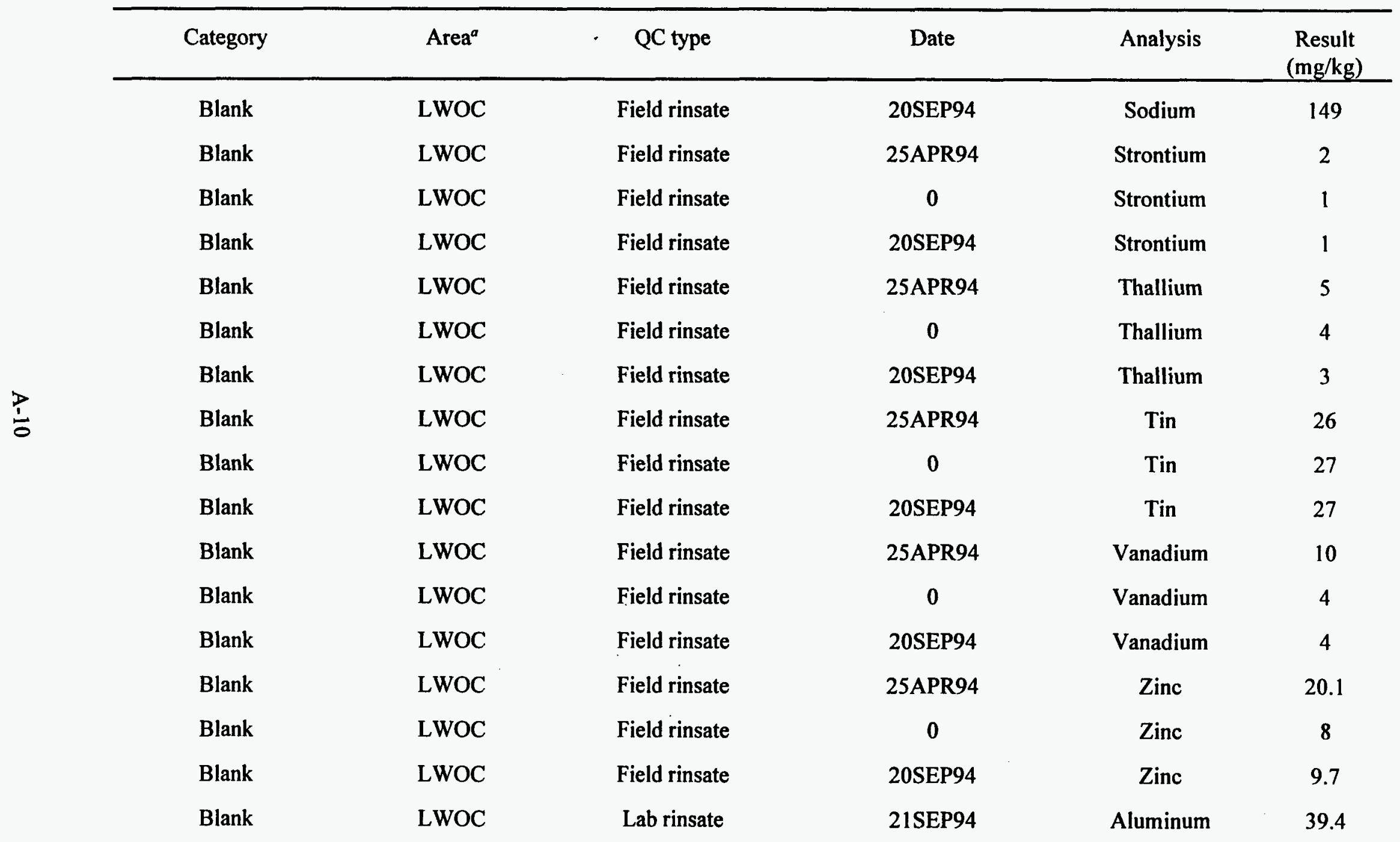


Table A.1 (continued)

\begin{tabular}{|c|c|c|c|c|c|}
\hline Category & Area $^{a}$ & QC type & Date & Analysis & $\begin{array}{c}\text { Result } \\
\text { (mg/kg) }\end{array}$ \\
\hline Blank & LWOC & Lab rinsate & 21SEP94 & Antimony & 46 \\
\hline Blank & LWOC & Lab rinsate & 21SEP94 & Arsenic & 2 \\
\hline Blank & LWOC & Lab rinsate & 21SEP94 & Barium & 14 \\
\hline Blank & LWOC & Lab rinsate & 21SEP94 & Beryllium & 1 \\
\hline Blank & LWOC & Lab rinsate & 21SEP94 & Boron & 61.1 \\
\hline Blank & LWOC & Lab rinsate & 21SEP94 & Cadmium & 3 \\
\hline Blank & LWOC & Lab rinsate & 21SEP94 & Calcium & 80.8 \\
\hline Blank & LWOC & Lab rinsate & 21SEP94 & Chromium & 4 \\
\hline Blank & LWOC & Lab rinsate & 21SEP94 & Cobalt & 8 \\
\hline Blank & LWOC & Lab rinsate & 21SEP94 & Copper & 2 \\
\hline Blank & LWOC & Lab rinsate & 21SEP94 & Iron & 26.2 \\
\hline Blank & LWOC & Lab rinsate & 21SEP94 & Lead & 2 \\
\hline Blank & LWOC & Lab rinsate & 21SEP94 & Lithium & 11 \\
\hline Blank & LWOC & Lab rinsate & 21SEP94 & Magnesium & 48 \\
\hline Blank & LWOC & Lab rinsate & 21SEP94 & Manganese & 2 \\
\hline Blank & LWOC & Lab rinsate & 21SEP94 & Mercury & 0.2 \\
\hline Blank & LWOC & Lab rinsate & 21SEP94 & Molybdenum & 14 \\
\hline
\end{tabular}


Table A.1 (continued)

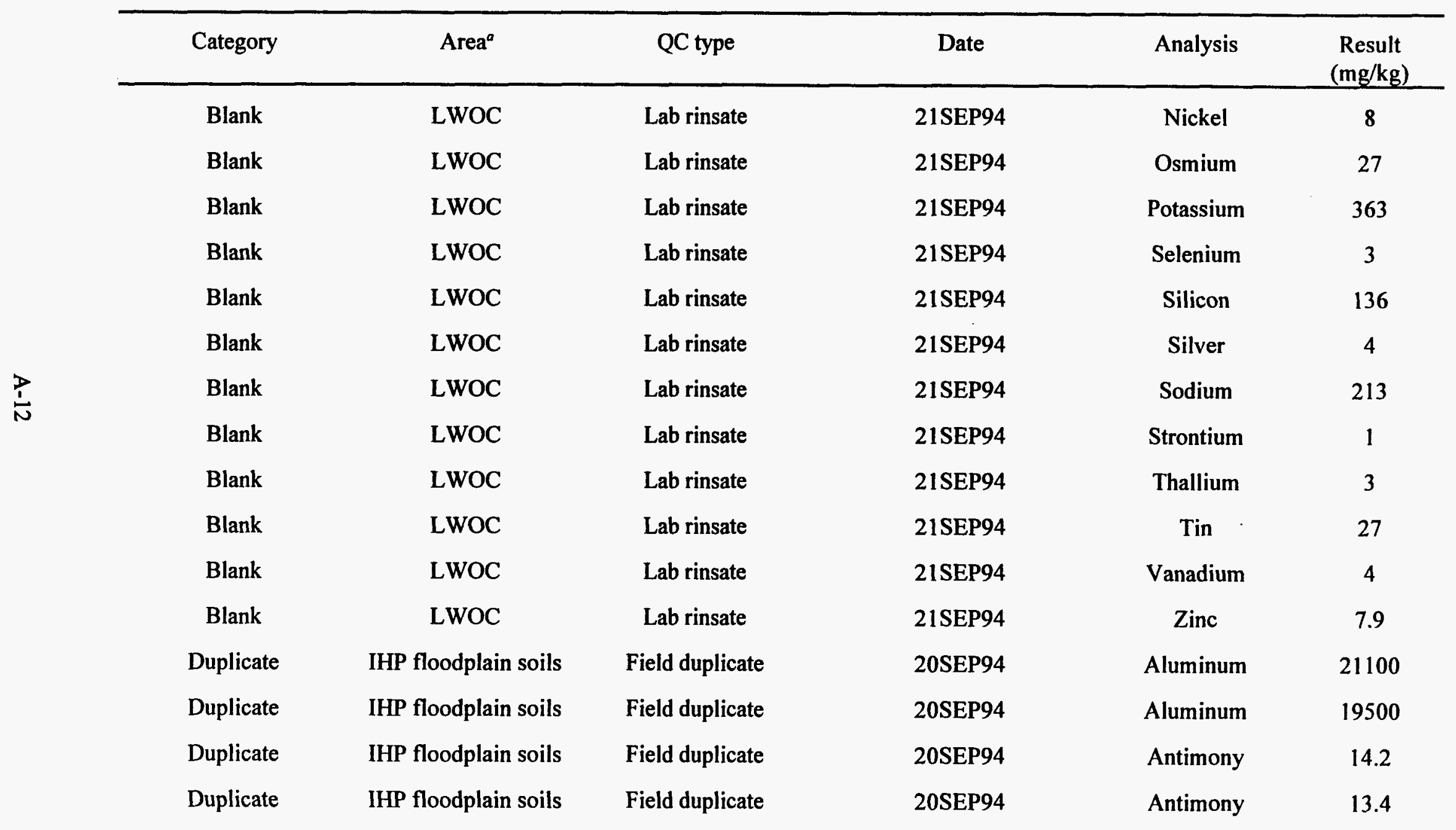


Table A.1 (continued)

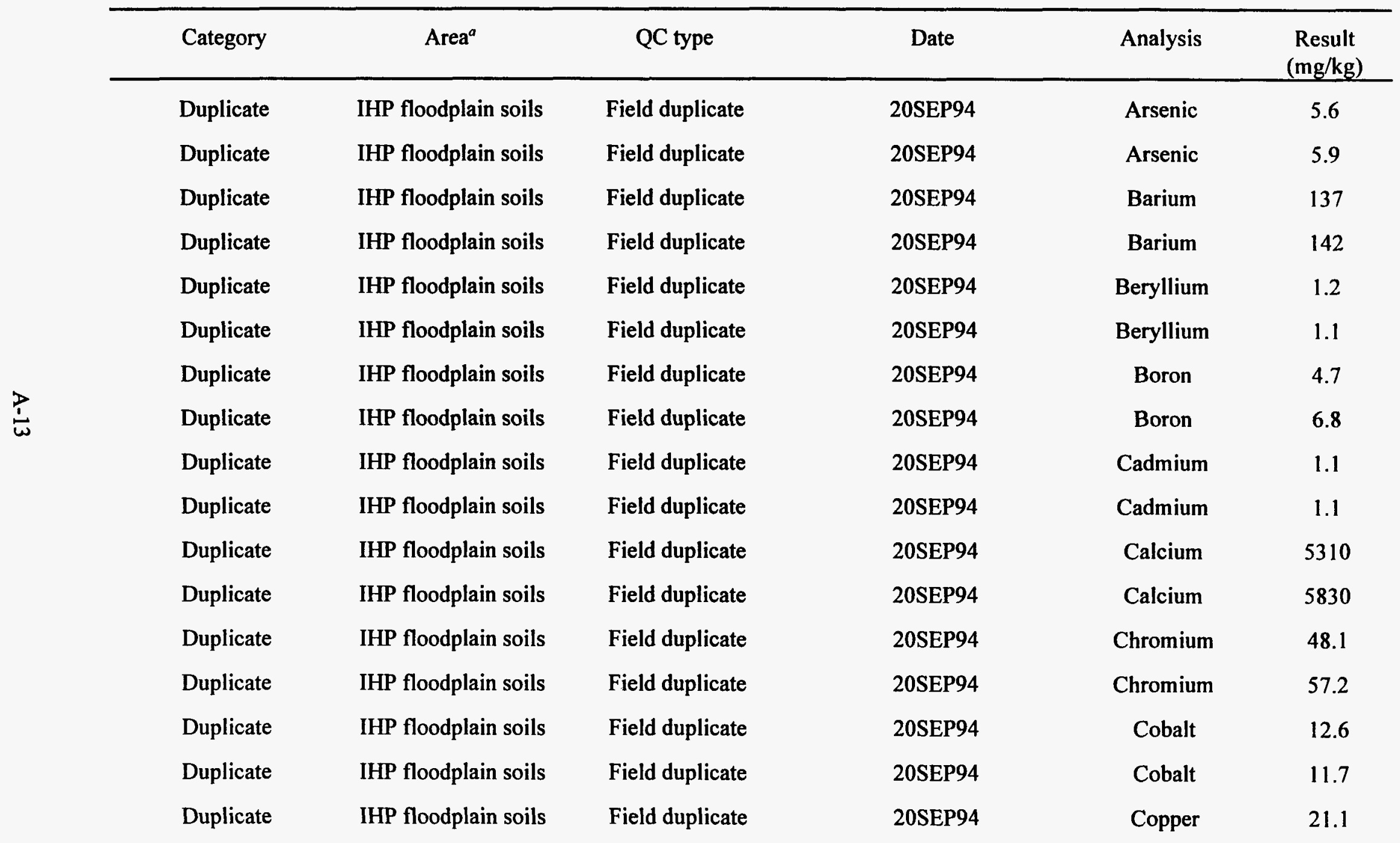


Table A.1 (continued)

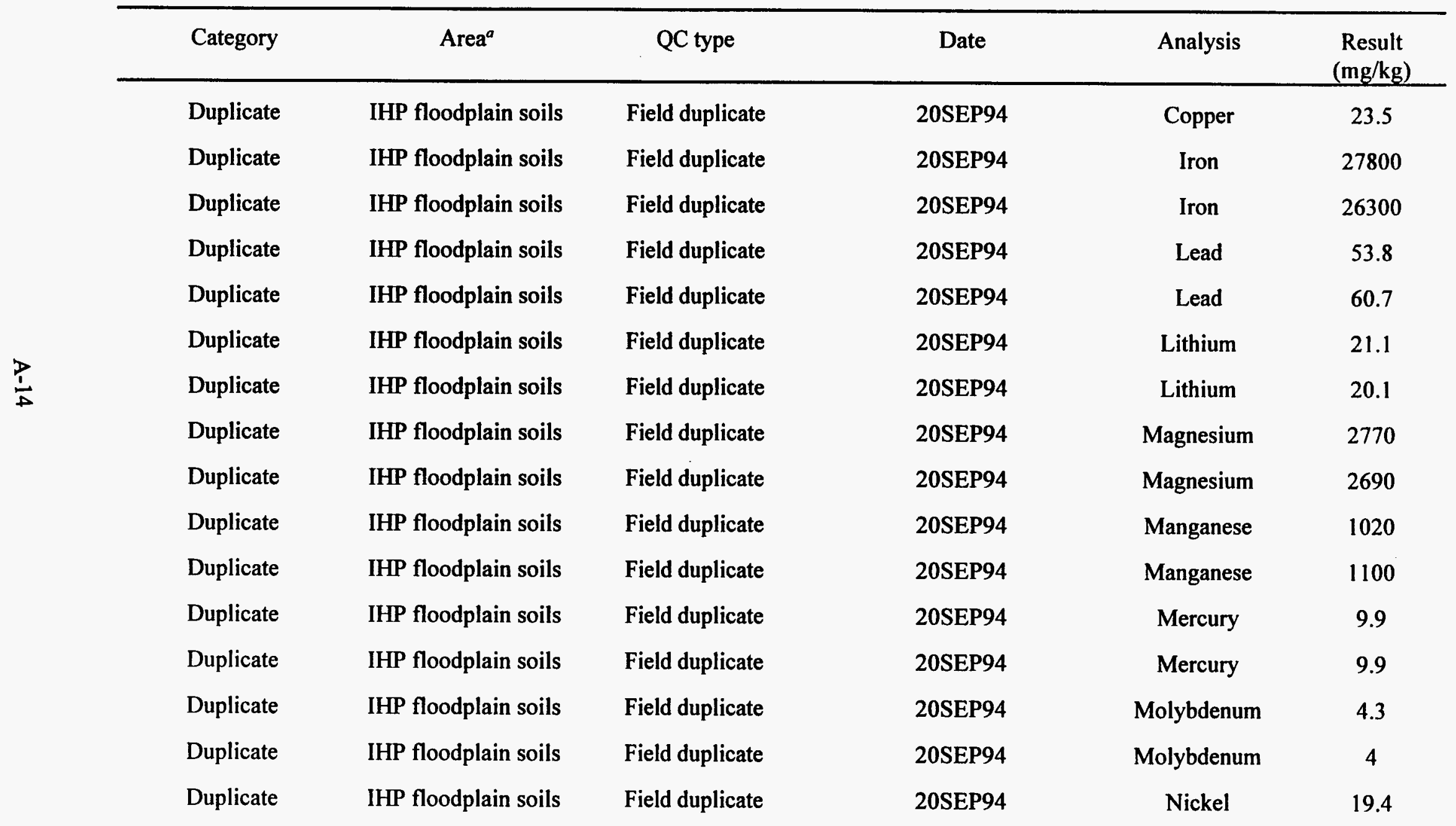


Table A.1 (continued)

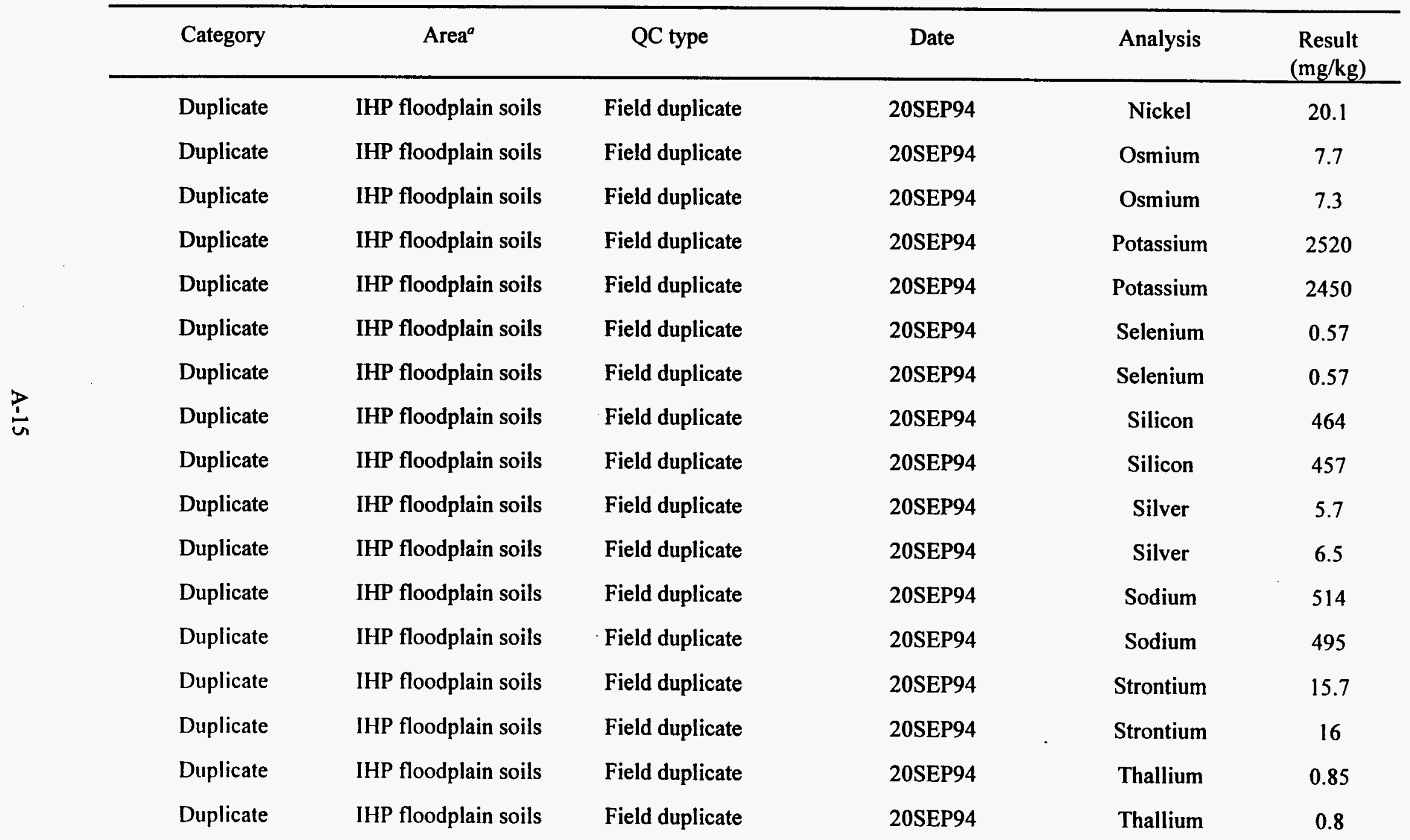


Table A.1 (continued)

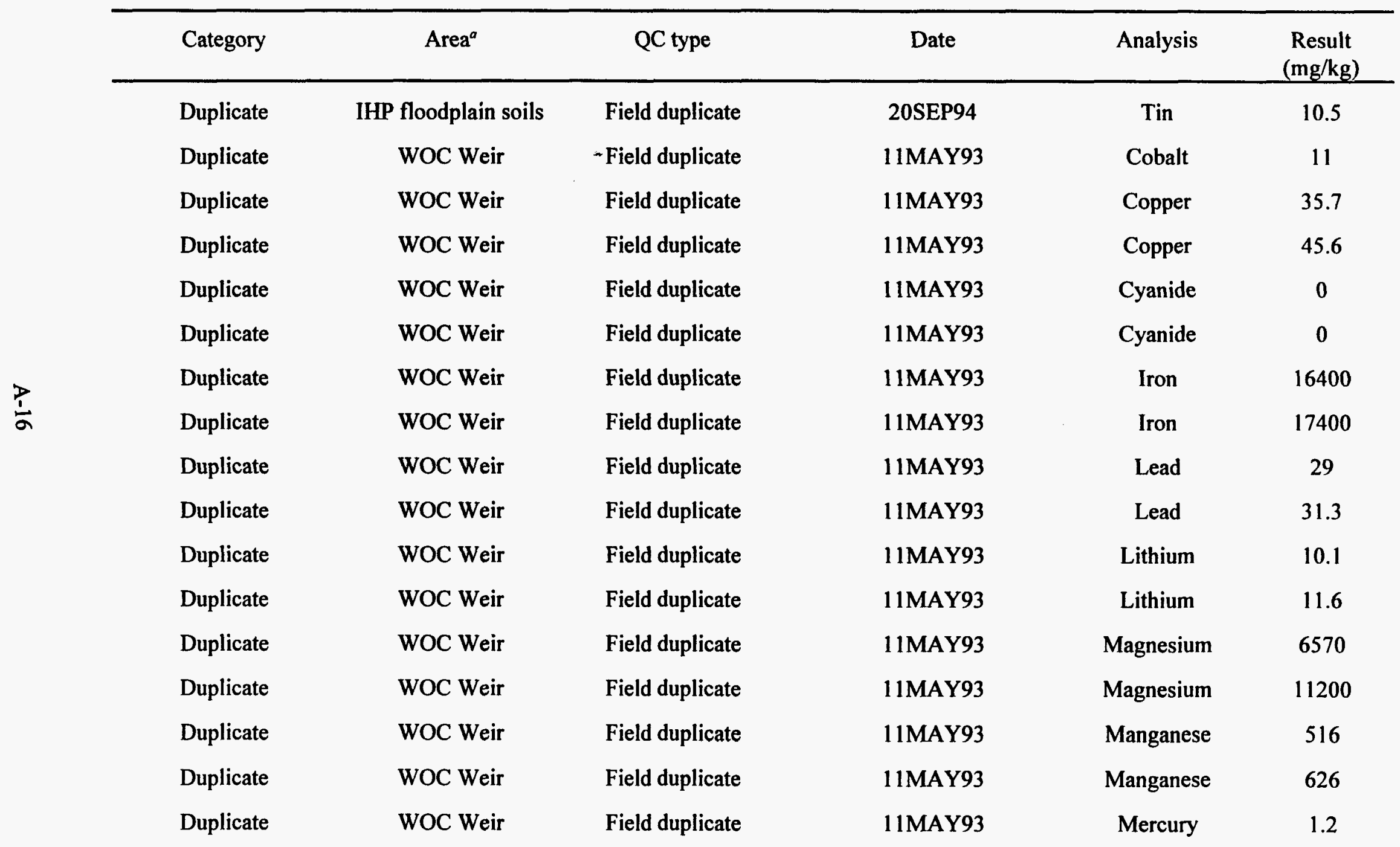


Table A.1 (continued)

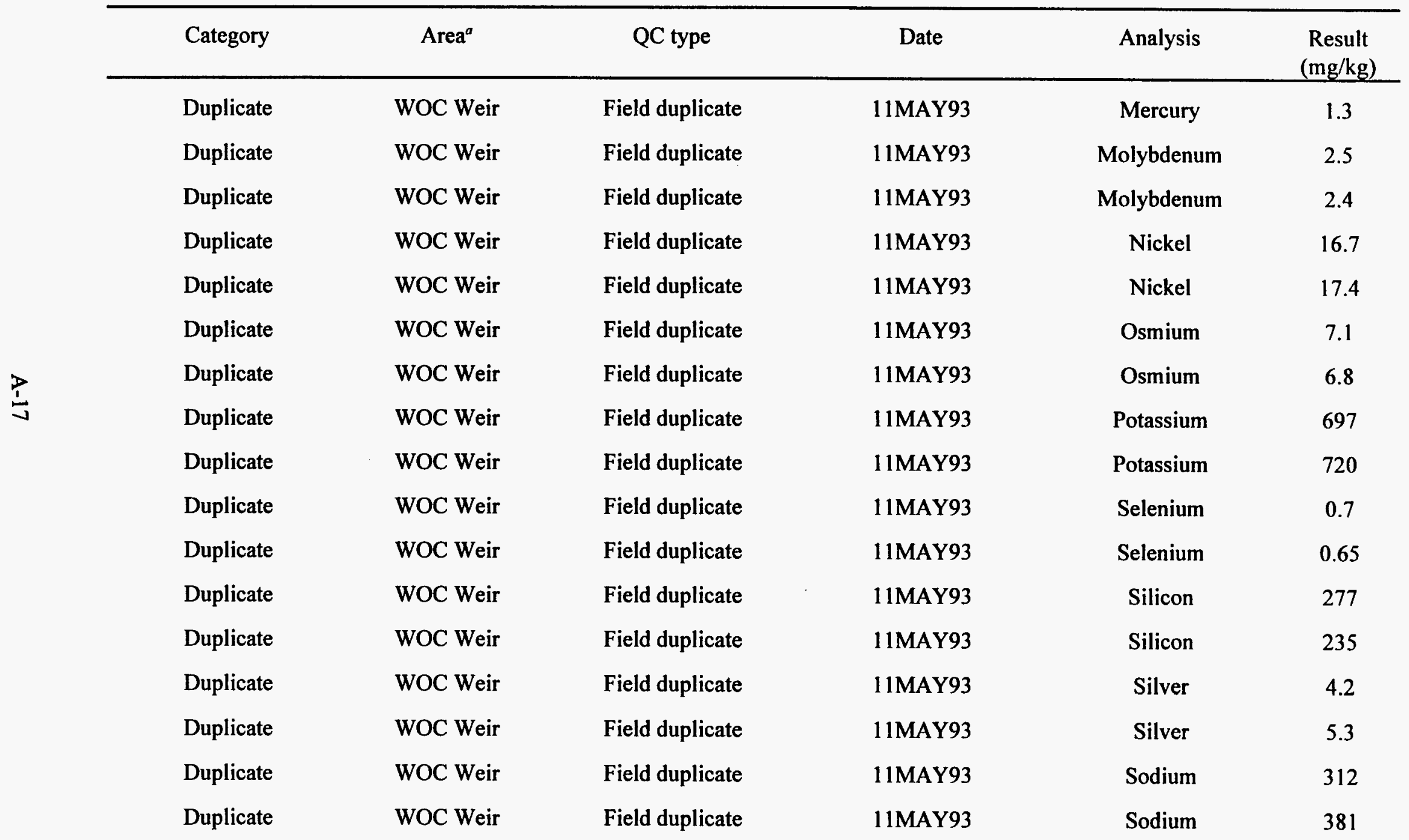


Table A.1 (continued)

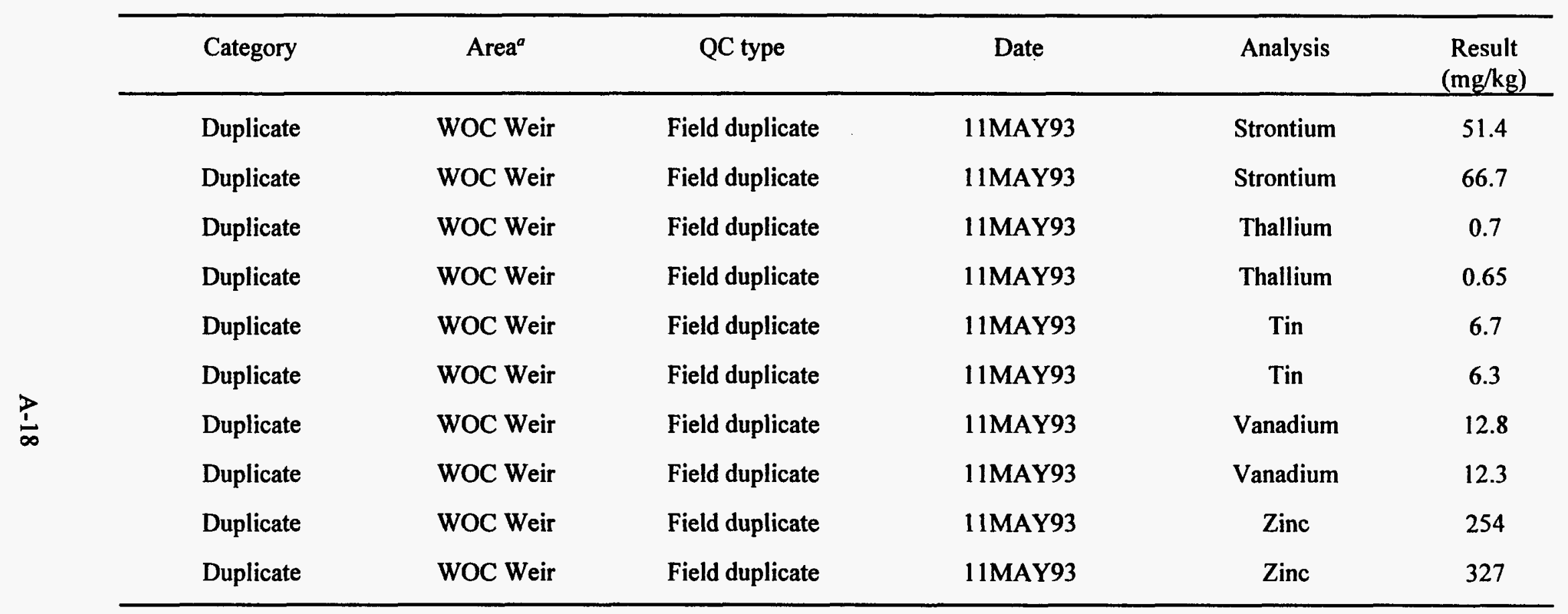

${ }^{\circledR} \mathrm{IHP}=$ Intermediate Holding Pond LWOC $=\mathrm{LWOC} ;$ WOC $=$ White Oak Creek. 
Table A.2. Results of organic soil blank samples submitted for quality control (QC) analysis

\begin{tabular}{|c|c|c|c|c|c|}
\hline QC type & Area $^{a}$ & Location & Date & Analysis & $\begin{array}{c}\text { Result } \\
(\mu \mathrm{g} / \mathrm{kg})\end{array}$ \\
\hline Blank & LWOC & Floodplain & 0 & 2-Methylnaphthalene & 23 \\
\hline Blank & LWOC & Floodplain & 0 & 2-Methylnaphthalene & 28 \\
\hline Blank & LWOC & Floodplain & 0 & 2-Methylnaphthalene & 83 \\
\hline Blank & LWOC & Floodplain & $\mathbf{0}$ & 2-Methylnaphthalene & 35 \\
\hline Blank & LWOC & Floodplain & 0 & 4-Methylphenol & 220 \\
\hline Blank & LWOC & Floodplain & 0 & Acenaphthene & 540 \\
\hline Blank & LWOC & Floodplain & 0 & Acenaphthene & 130 \\
\hline Blank & LWOC & Floodplain & 0 & Acenaphthene & 28 \\
\hline Blank & LWOC & Floodplain & 0 & Acenaphthene & 22 \\
\hline Blank & LWOC & Floodplain & 0 & Acenaphthene & 92 \\
\hline Blank & LWOC & Floodplain & 0 & Acenaphthene & 130 \\
\hline Blank & LWOC & Floodplain & 0 & Anthracene & 460 \\
\hline Blank & LWOC & Floodplain & 0 & Anthracene & 120 \\
\hline Blank & LWOC & Floodplain & 0 & Anthracene & 72 \\
\hline Blank & LWOC & Floodplain & 0 & Anthracene & 220 \\
\hline Blank & LWOC & Floodplain & 0 & Anthracene & 34 \\
\hline Blank & LWOC & Floodplain & 0 & Anthracene & 40 \\
\hline
\end{tabular}


Table A.2 (continued)

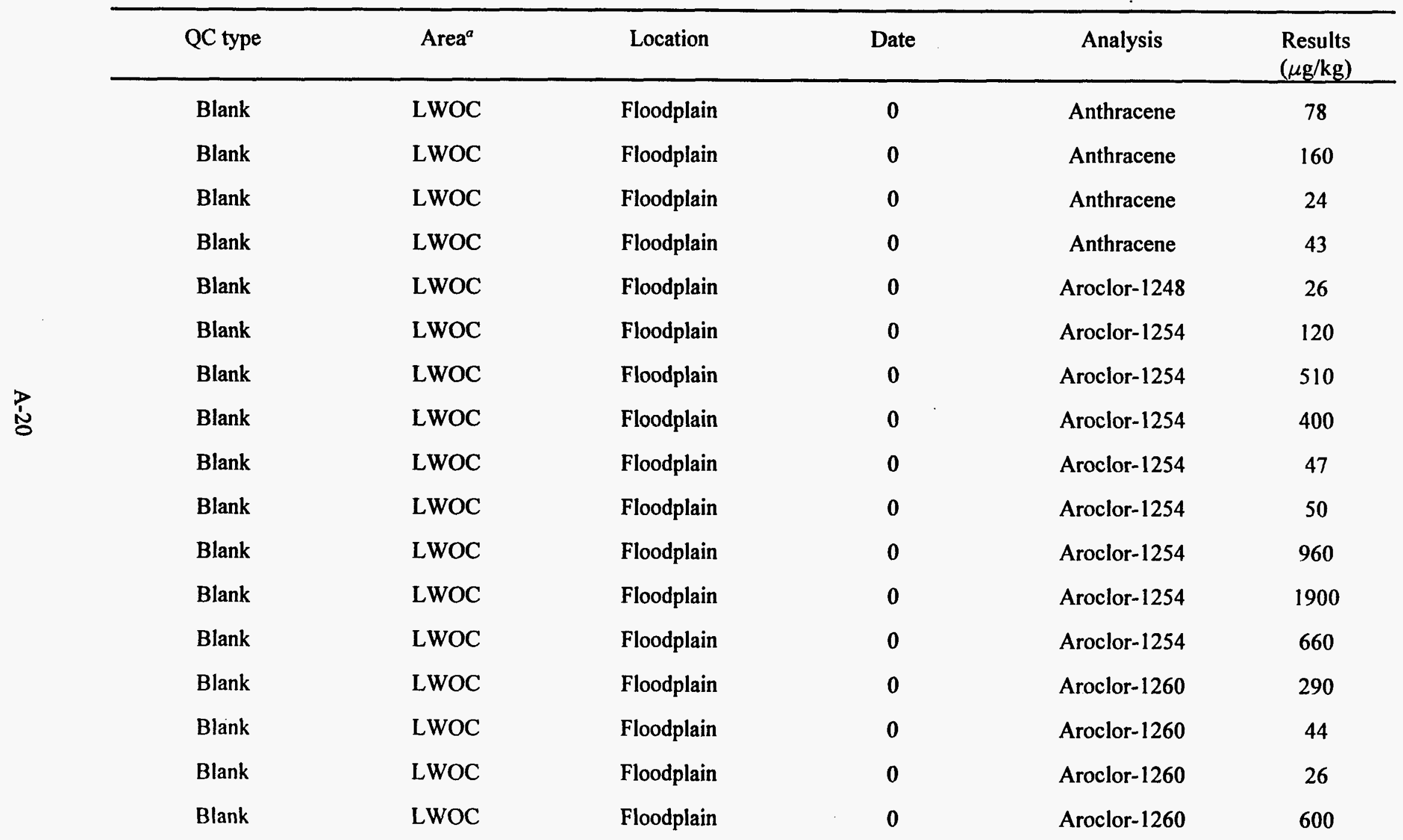


Table A.2 (continued)

\begin{tabular}{|c|c|c|c|c|c|}
\hline QC type & Area $^{a}$ & Location & Date & Analysis & $\begin{array}{c}\text { Result } \\
(\mu \mathrm{g} / \mathrm{kg})\end{array}$ \\
\hline Blank & LWOC & Floodplain & 0 & Aroclor-1260 & 150 \\
\hline Blank & LWOC & Floodplain & $\mathbf{0}$ & Aroclor- 1260 & 190 \\
\hline Blank & LWOC & Floodplain & 0 & Aroclor-1260 & 100 \\
\hline Blank & LWOC & Floodplain & 0 & Aroclor-1260 & 62 \\
\hline Blank & LWOC & Floodplain & 0 & Aroclor- 1260 & 87 \\
\hline Blank & LWOC & Floodplain & 0 & Aroclor-1260 & 91 \\
\hline Blank & LWOC & Floodplain & 0 & Aroclor-1260 & 110 \\
\hline Blank & LWOC & Floodplain & 0 & Aroclor- 1260 & 410 \\
\hline Blank & LWOC & Floodplain & 0 & Aroclor-1260 & 400 \\
\hline Blank & LWOC & Floodplain & 0 & Aroclor- 1260 & 38 \\
\hline Blank & LWOC & Floodplain & 0 & Aroclor-1260 & 59 \\
\hline Blank & LWOC & Floodplain & 0 & Aroclor-1260 & 300 \\
\hline Blank & LWOC & Floodplain & 0 & Aroclor-1260 & 450 \\
\hline Blank & LWOC & Floodplain & 0 & Aroclor-1260 & 46 \\
\hline Blank & LWOC & Floodplain & 0 & Aroclor-1260 & 26 \\
\hline Blank & LWOC & Floodplain & 0 & Aroclor-1260 & 610 \\
\hline Blank & LWOC & Floodplain & 0 & Aroclor- 1260 & 140 \\
\hline
\end{tabular}


Table A.2 (continued)

\begin{tabular}{|c|c|c|c|c|c|}
\hline QC type & Area $^{a}$ & Location & Date & Analysis & $\begin{array}{c}\text { Result } \\
(\mu \mathrm{g} / \mathrm{kg})\end{array}$ \\
\hline Blank & LWOC & Floodplain & $\mathbf{0}$ & Aroclor- 1260 & 610 \\
\hline Blank & LWOC & Floodplain & $\mathbf{0}$ & Aroclor- 1260 & 220 \\
\hline Blank & LWOC & Floodplain & 0 & Aroclor- 1260 & 730 \\
\hline Blank & LWOC & Floodplain & 0 & Aroclor -1260 & 1000 \\
\hline Blank & LWOC & Floodplain & $\mathbf{0}$ & Aroclor- 1260 & 290 \\
\hline Blank & LWOC & Floodplain & $\mathbf{0}$ & Aroclor- 1260 & 530 \\
\hline Blank & LWOC & Floodplain & $\mathbf{0}$ & Benzo(a)anthracene & 890 \\
\hline Blank & LWOC & Floodplain & 0 & Benzo(a)anthracene & 530 \\
\hline Blank & LWOC & Floodplain & 0 & Benzo(a)anthracene & 370 \\
\hline Blank & LWOC & Floodplain & 0 & Benzo(a)anthracene & 98 \\
\hline Blank & LWOC & Floodplain & 0 & Benzo(a)anthracene & 19 \\
\hline Blank & LWOC & Floodplain & 0 & Benzo(a)anthracene & 670 \\
\hline Blank & LWOC & Floodplain & 0 & Benzo(a)anthracene & 130 \\
\hline Blank & LWOC & Floodplain & 0 & Benzo(a)anthracene & 32 \\
\hline Blank & LWOC & Floodplain & 0 & Benzo(a)anthracene & 54 \\
\hline Blank & LWOC & Floodplain & 0 & Benzo(a)anthracene & 31 \\
\hline Blank & LWOC & Floodplain & 0 & Benzo(a)anthracene & 550 \\
\hline
\end{tabular}


Table A.2 (continued)

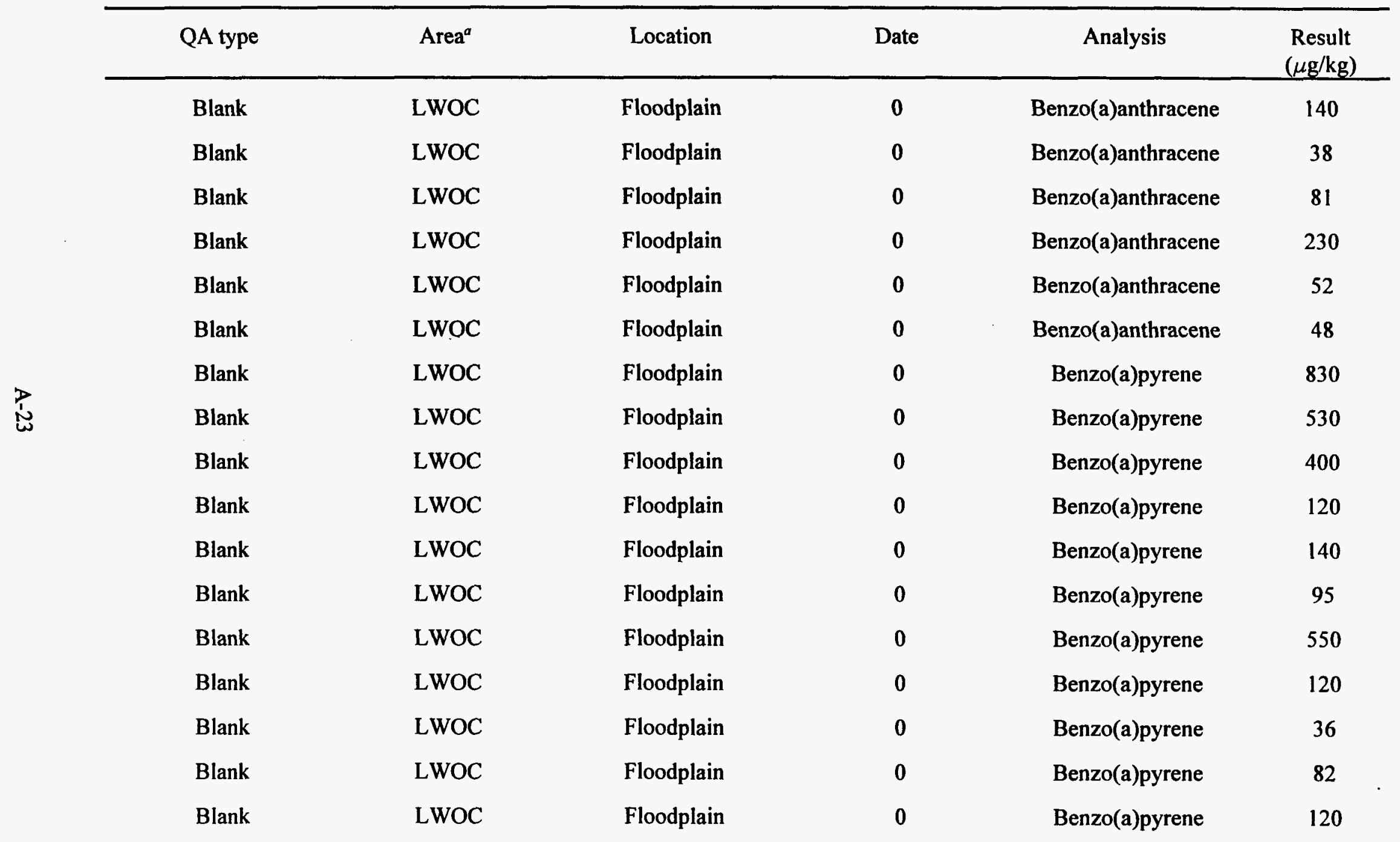


Table A.2 (continued)

\begin{tabular}{|c|c|c|c|c|c|}
\hline QC type & Area $^{a}$ & Location & Date & Analysis & $\begin{array}{c}\text { Result } \\
(\mu \mathrm{g} / \mathrm{kg})\end{array}$ \\
\hline Blank & LWOC & Floodplain & 0 & Benzo(a)pyrene & 68 \\
\hline Blank & LWOC & Floodplain & 0 & Benzo(a)pyrene & 470 \\
\hline Blank & LWOC & Floodplain & 0 & Benzo(a)pyrene & 140 \\
\hline Blank & LWOC & Floodplain & $\mathbf{0}$ & Benzo(a)pyrene & 100 \\
\hline Blank & LWOC & Floodplain & $\mathbf{0}$ & Benzo(a)pyrene & 200 \\
\hline Blank & LWOC & Floodplain & 0 & Benzo(a)pyrene & 66 \\
\hline Blank & LWOC & Floodplain & $\mathbf{0}$ & Benzo(a)pyrene & 60 \\
\hline Blank & LWOC & Floodplain & $\mathbf{0}$ & Benzo(b)fluoranthene & 390 \\
\hline Blank & LWOC & Floodplain & 0 & Benzo(b)fluoranthene & 170 \\
\hline Blank & LWOC & Floodplain & $\mathbf{0}$ & Benzo(b)fluoranthene & 130 \\
\hline Blank & LWOC & Floodplain & $\mathbf{0}$ & Benzo(b)fluoranthene & 120 \\
\hline Blank & LWOC & Floodplain & 0 & Benzo(b)fluoranthene & 49 \\
\hline Blank & LWOC & Floodplain & 0 & Benzo(b)fluoranthene & 790 \\
\hline
\end{tabular}


Table A.2 (continued)

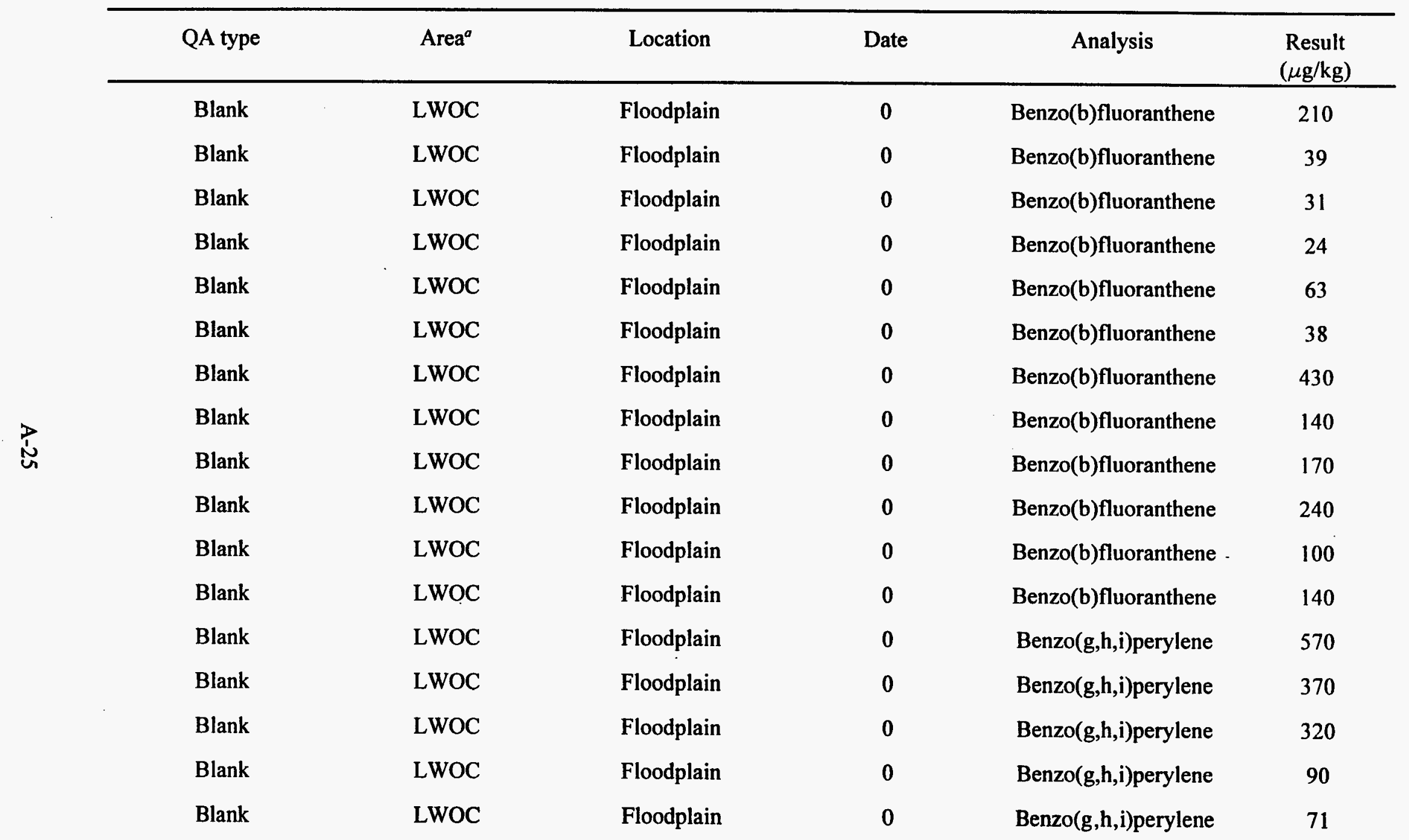


Table A.2 (continued)

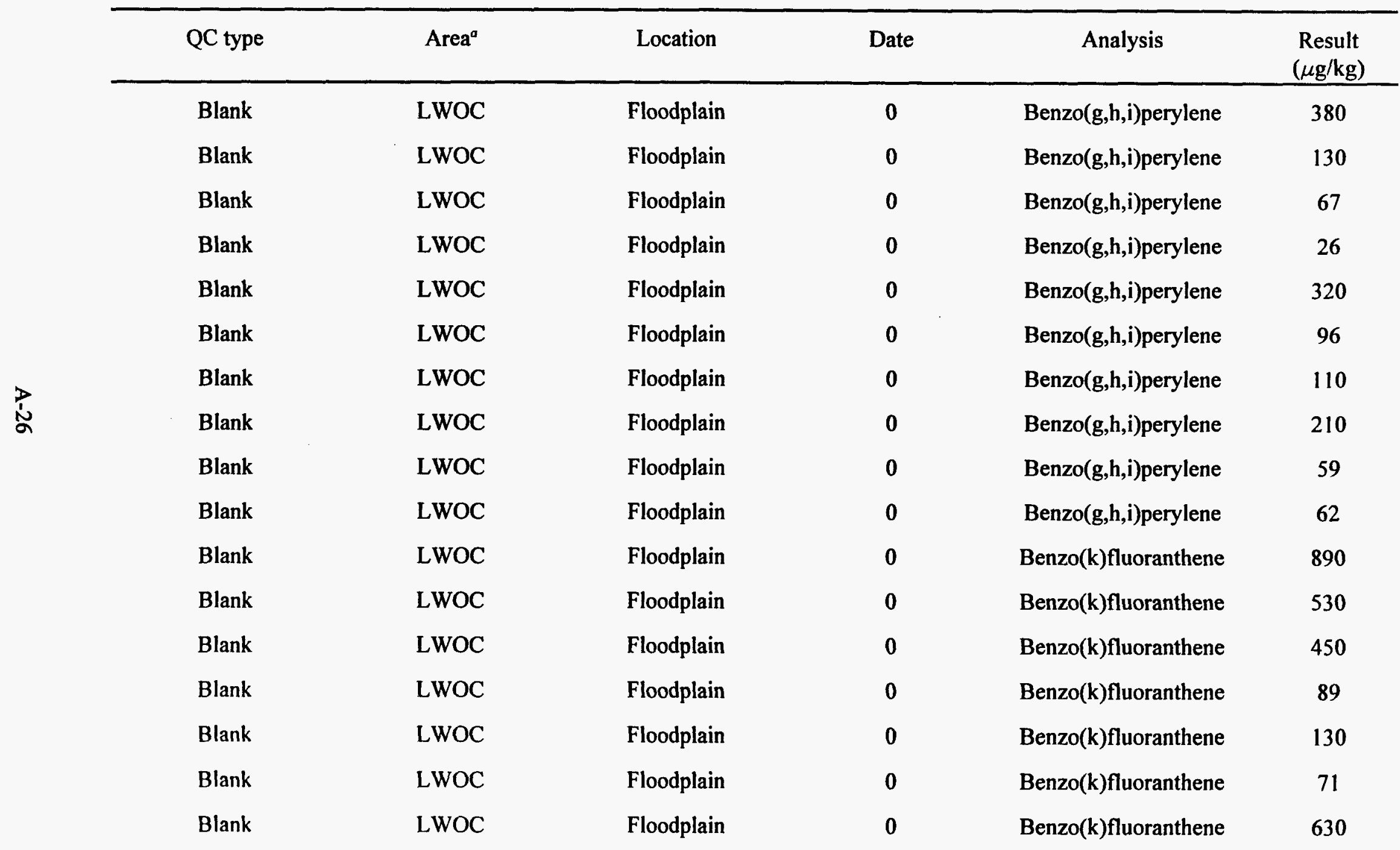


Table A.2 (continued)

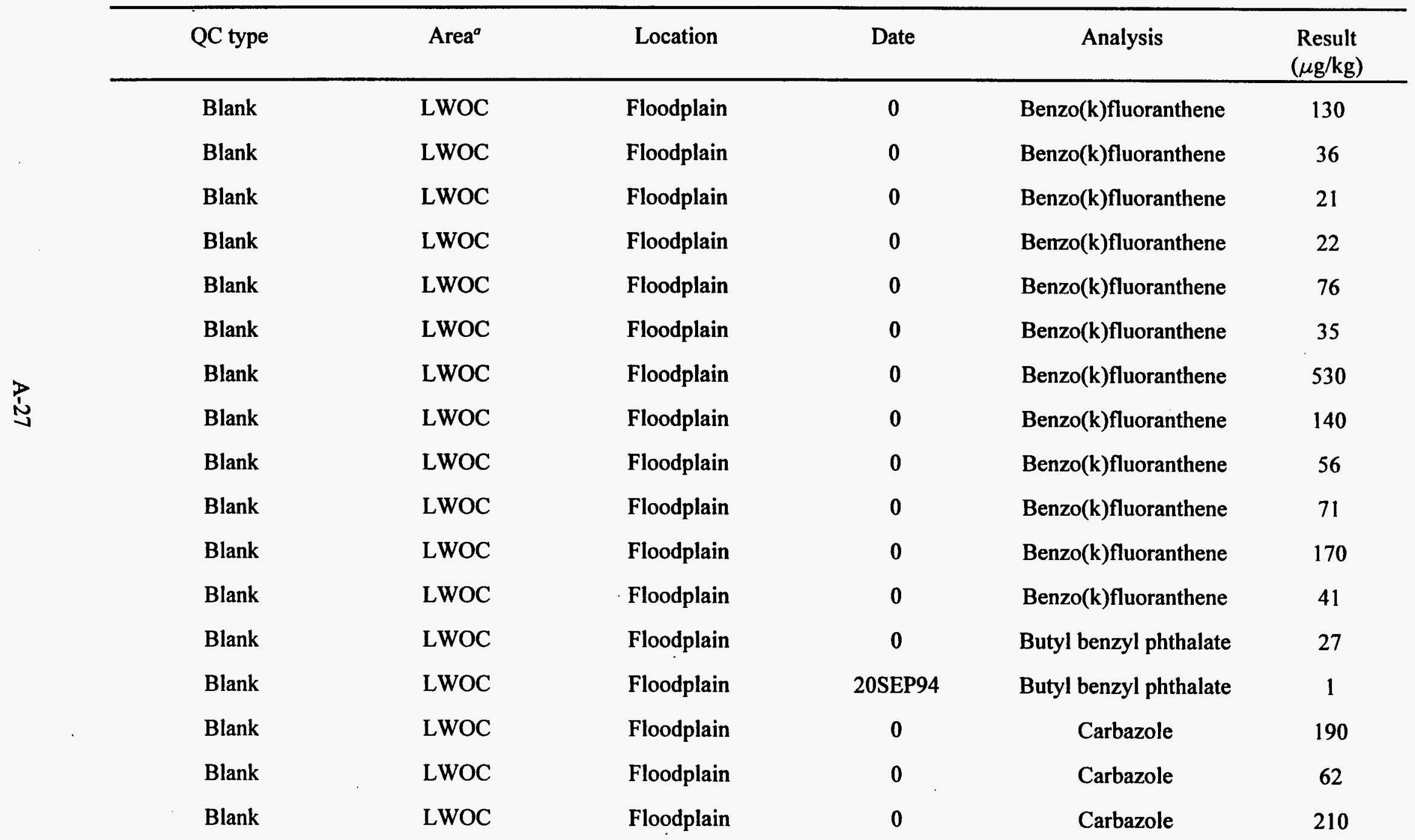


Table A.2 (continued)

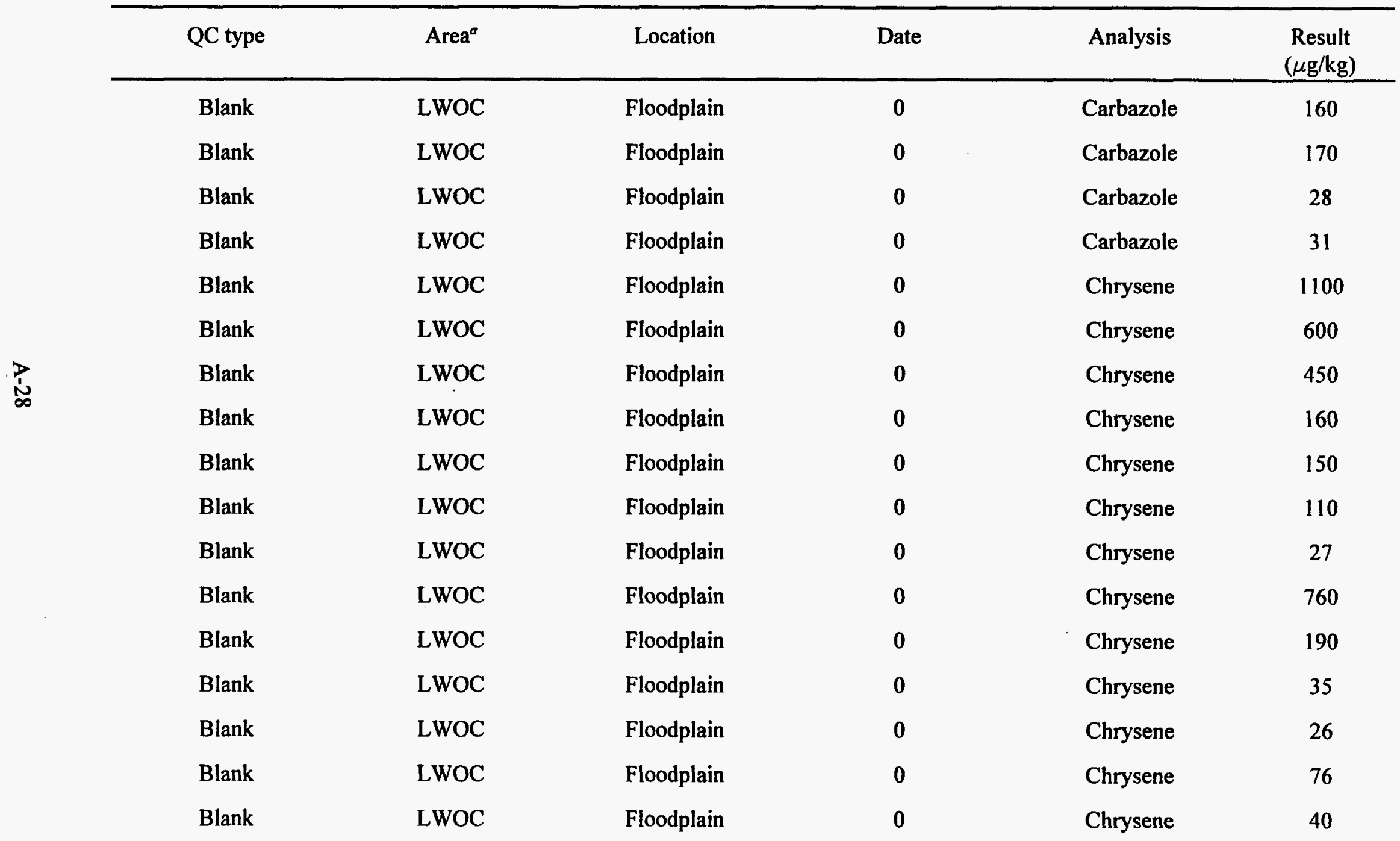


Table A.2 (continued)

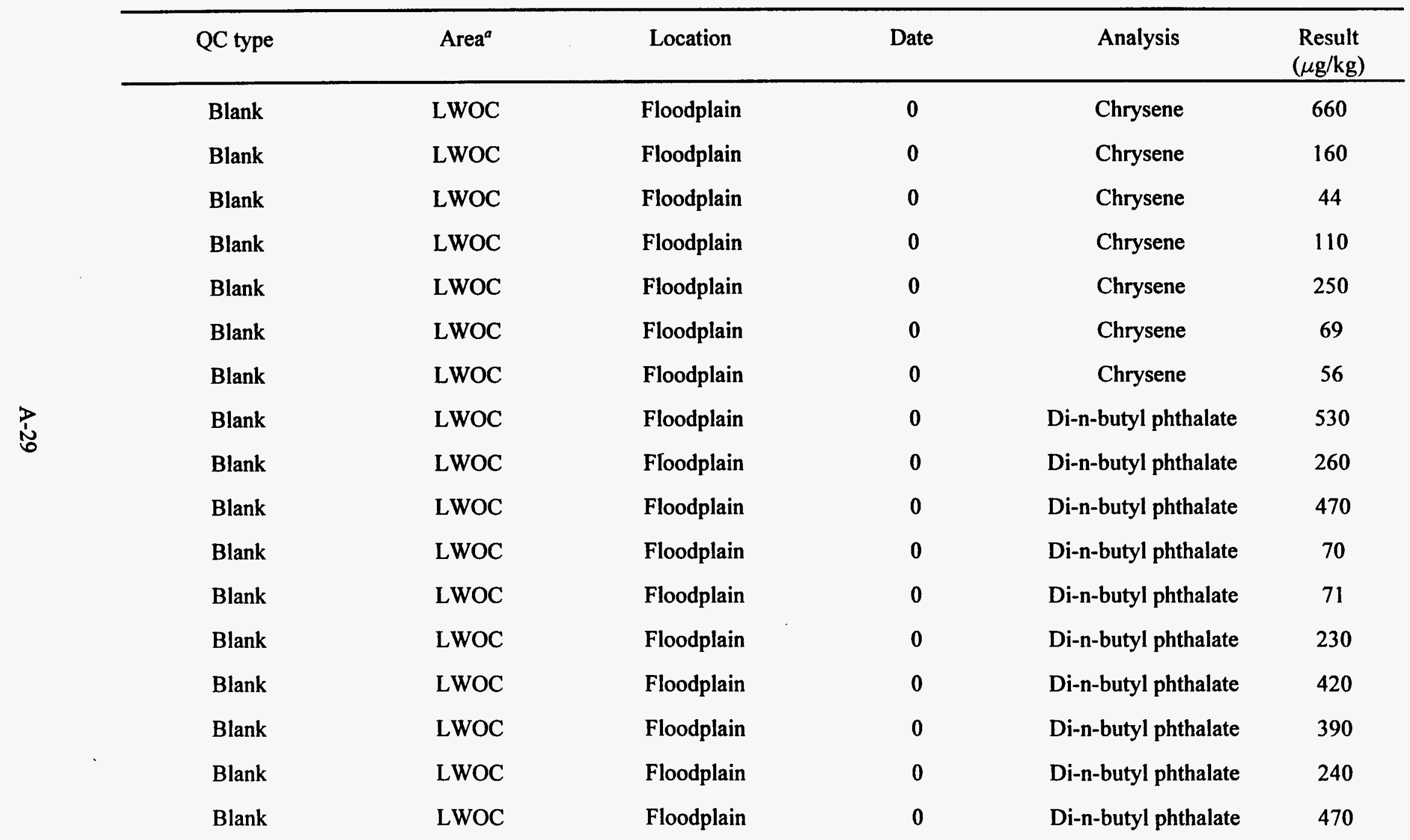


Table A.2 (continued)

\begin{tabular}{|c|c|c|c|c|c|}
\hline QC type & Area $^{a}$ & Location & Date & Analysis & $\begin{array}{c}\text { Result } \\
(\mu \mathrm{g} / \mathrm{kg})\end{array}$ \\
\hline Blank & LWOC & Floodplain & 0 & Di-n-butyl phthalate & 10 \\
\hline Blank & LWOC & Floodplain & 0 & Di-n-butyl phthalate & 110 \\
\hline Blank & LWOC & Floodplain & 0 & Di-n-butyl phthalate & 33 \\
\hline Blank & LWOC & Floodplain & 0 & Di-n-butyl phthalate & 44 \\
\hline Blank & LWOC & Floodplain & 20SEP94 & Di-n-butyl phthalate & 1 \\
\hline Blank & LWOC & Floodplain & 21SEP94 & Di-n-butyl phthalate & 6 \\
\hline Blank & LWOC & Floodplain & 0 & Di-n-butyl phthalate & 200 \\
\hline Blank & LWOC & Floodplain & 0 & Di-n-butyl phthalate & 170 \\
\hline Blank & LWOC & Floodplain & 0 & Di-n-butyl phthalate & 250 \\
\hline Blank & LWOC & Floodplain & 0 & Di-n-butyl phthalate & 100 \\
\hline Blank & LWOC & Floodplain & 0 & Di-n-butyl phthalate & 420 \\
\hline Blank & LWOC & Floodplain & 0 & Di-n-butyl phthalate & 180 \\
\hline Blank & LWOC & Floodplain & 0 & Di-n-butyl phthalate & 180 \\
\hline
\end{tabular}


Table A.2 (continued)

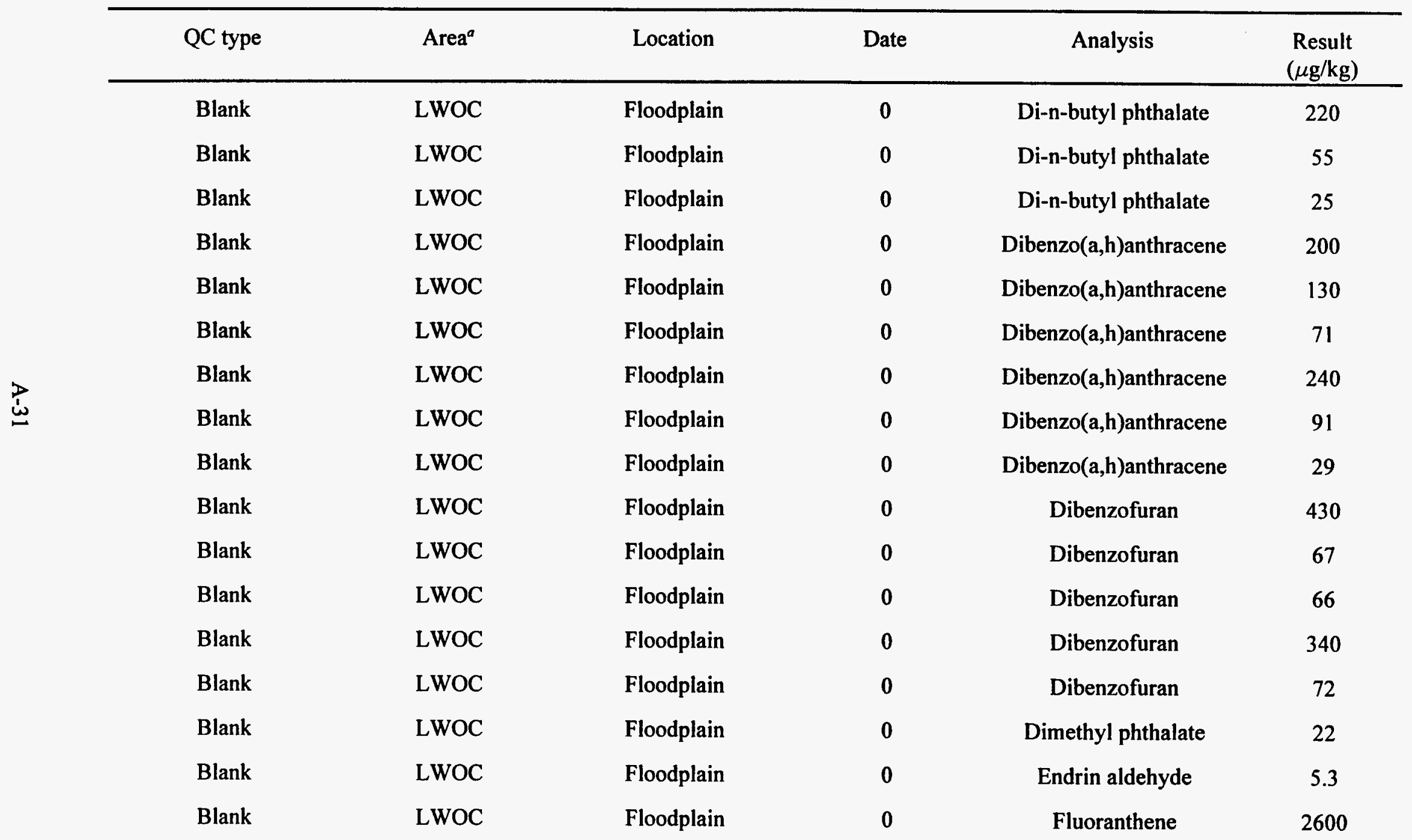


Table A.2 (continued)

\begin{tabular}{|c|c|c|c|c|c|}
\hline QC type & Area $^{a}$ & Location & Date & Analysis & $\begin{array}{c}\text { Result } \\
(\mu \mathrm{g} / \mathrm{kg})\end{array}$ \\
\hline Blank & LWOC & Floodplain & 0 & Fluoranthene & 1300 \\
\hline Blank & LWOC & Floodplain & 0 & Fluoranthene & 890 \\
\hline Blank & LWOC & Floodplain & 0 & Fluoranthene & 280 \\
\hline Blank & LWOC & Floodplain & 0 & Fluoranthene & 63 \\
\hline Blank & LWOC & Floodplain & 0 & Fluoranthene & 390 \\
\hline Blank & LWOC & Floodplain & 0 & Fluoranthene & 220 \\
\hline Blank & LWOC & Floodplain & 0 & Fluoranthene & 47 \\
\hline Blank & LWOC & Floodplain & 0 & Fluoranthene & 1400 \\
\hline Blank & LWOC & Floodplain & 0 & Fluoranthene & 370 \\
\hline Blank & LWOC & Floodplain & 0 & Fluoranthene & 110 \\
\hline Blank & LWOC & Floodplain & 0 & Fluoranthene & 120 \\
\hline Blank & LWOC & Floodplain & 0 & Fluoranthene & 27 \\
\hline Blank & LWOC & Floodplain & 0 & Fluoranthene & 200 \\
\hline Blank & LWOC & Floodplain & 0 & Fluoranthene & 32 \\
\hline Blank & LWOC & Floodplain & 0 & Fluoranthene & 100 \\
\hline Blank & LWOC & Floodplain & 0 & Fluoranthene & 56 \\
\hline Blank & LWOC & Floodplain & 0 & Fluoranthene & 1100 \\
\hline
\end{tabular}


Table A.2 (continued)

\begin{tabular}{|c|c|c|c|c|c|}
\hline QC type & Area $^{a}$ & Location & Date & Analysis & $\begin{array}{c}\text { Result } \\
(\mu \mathrm{g} / \mathrm{kg}) \\
\end{array}$ \\
\hline Blank & LWOC & Floodplain & 0 & Fluoranthene & 260 \\
\hline Blank & LWOC & Floodplain & 0 & Fluoranthene & 73 \\
\hline Blank & LWOC & Floodplain & 0 & Fluoranthene & 160 \\
\hline Blank & LWOC & Floodplain & 0 & Fluoranthene & 430 \\
\hline Blank & LWOC & Floodplain & 0 & Fluoranthene & 110 \\
\hline Blank & LWOC & Floodplain & 0 & Fluoranthene & 83 \\
\hline Blank & LWOC & Floodplain & 0 & Fluorene & 1000 \\
\hline Blank & LWOC & Floodplain & 0 & Fluorene & 140 \\
\hline Blank & LWOC & Floodplain & 0 & Fluorene & 38 \\
\hline Blank & LWOC & Floodplain & 0 & Fluorene & 96 \\
\hline Blank & LWOC & Floodplain & 0 & Fluorene & 450 \\
\hline Blank & LWOC & Floodplain & 0 & Fluorene & 140 \\
\hline Blank & LWOC & Floodplain & 0 & Indeno(1,2,3-cd)pyrene & 640 \\
\hline Blank & LWOC & Floodplain & 0 & Indeno(1,2,3-cd)pyrene & 400 \\
\hline Blank & LWOC & Floodplain & 0 & Indeno(1,2,3-cd)pyrene & 360 \\
\hline Blank & LWOC & Floodplain & $\mathbf{0}$ & Indeno(1,2,3-cd)pyrene & 120 \\
\hline Blank & LWOC & Floodplain & 0 & Indeno(1,2,3-cd)pyrene & 18 \\
\hline
\end{tabular}


Table A.2 (continued)

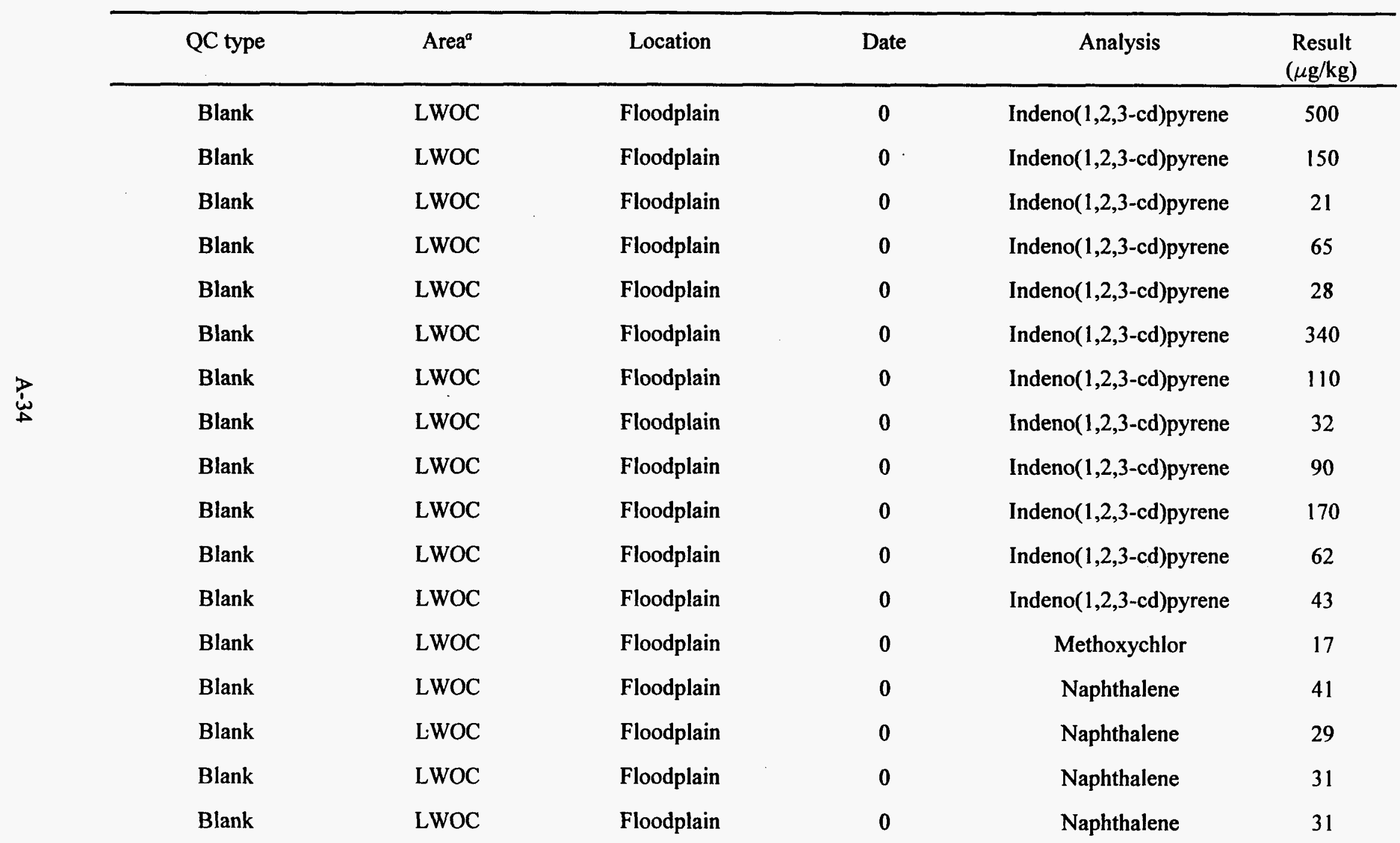


Table A.2 (continued)

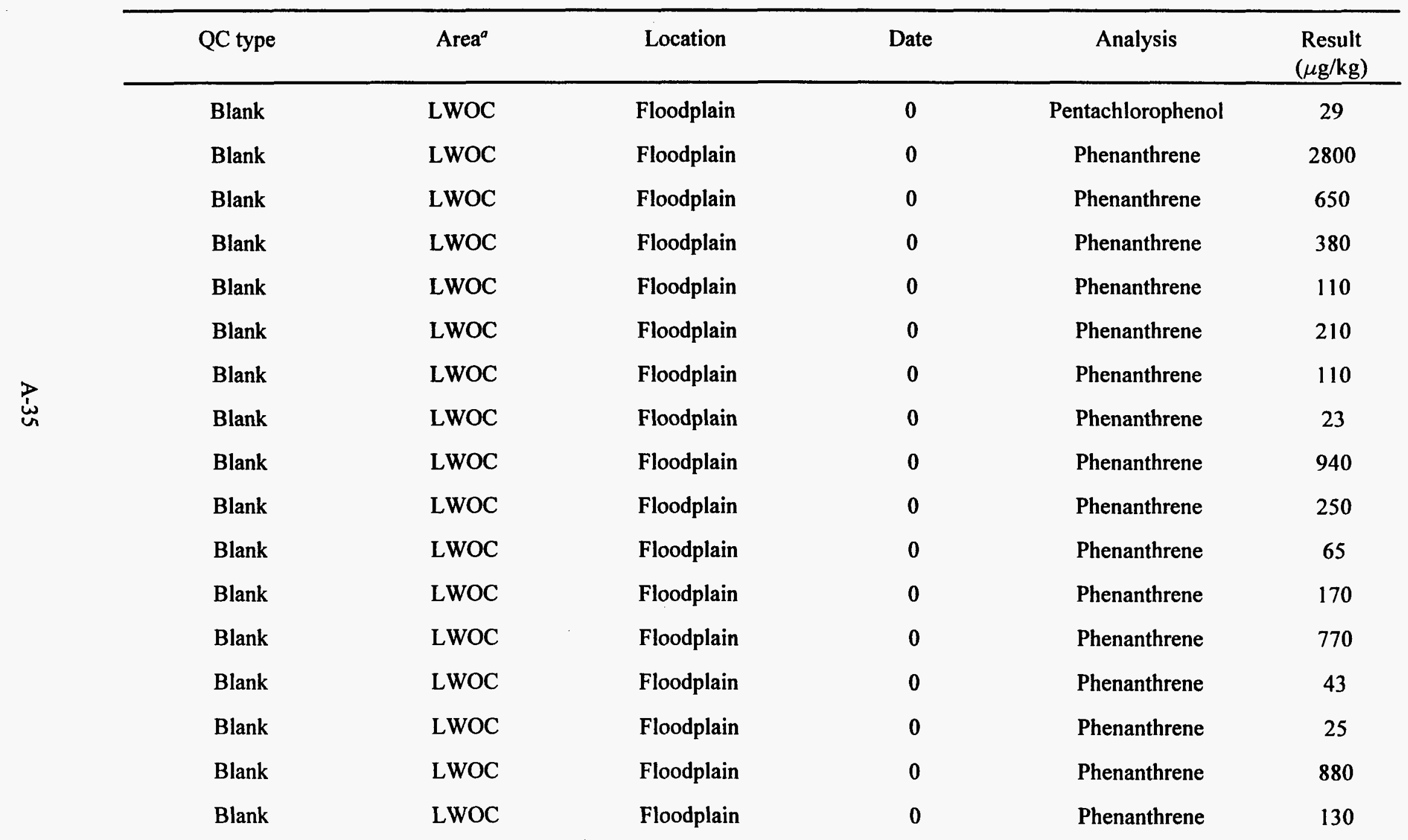


Table A.2 (continued)

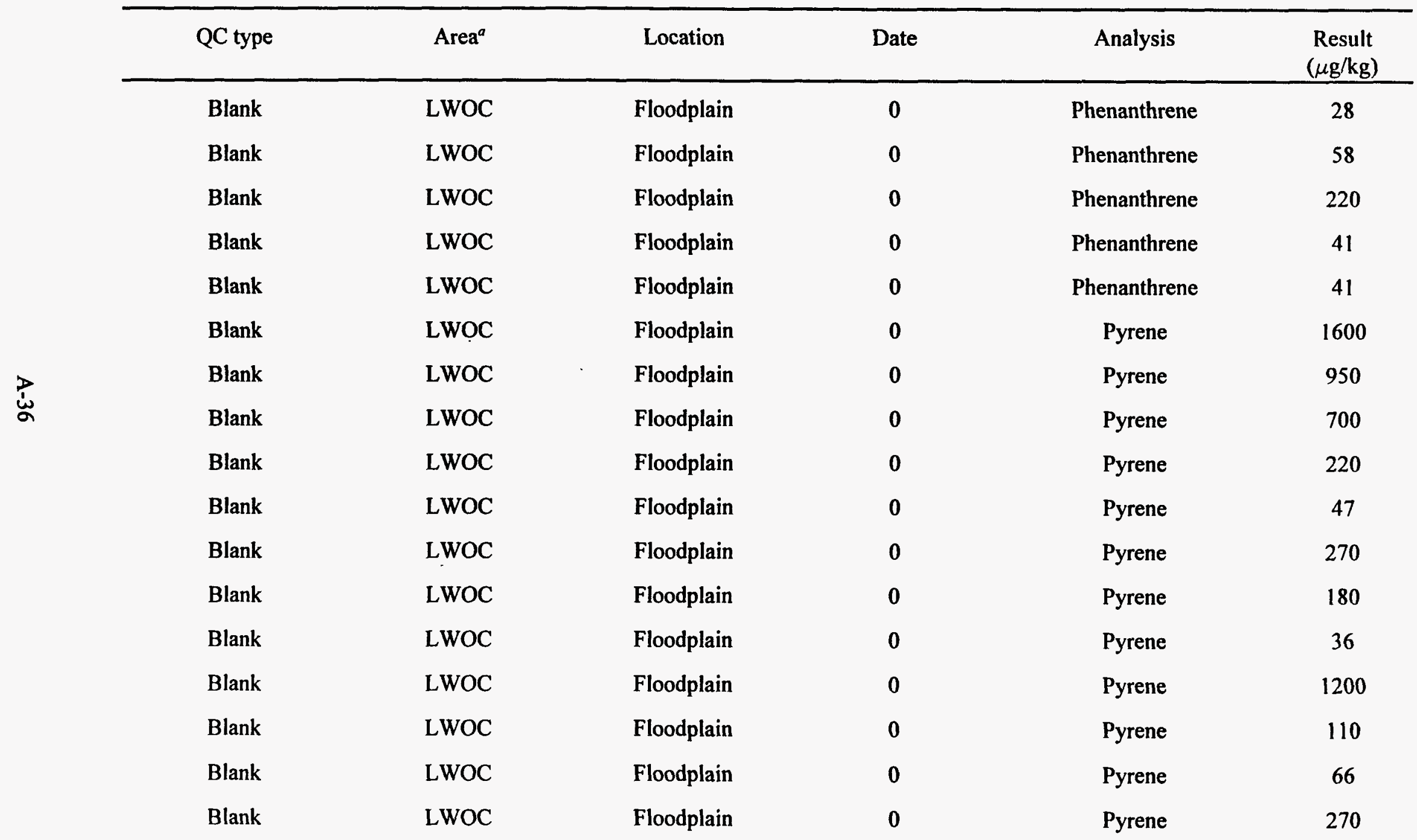


Table A.2 (continued)

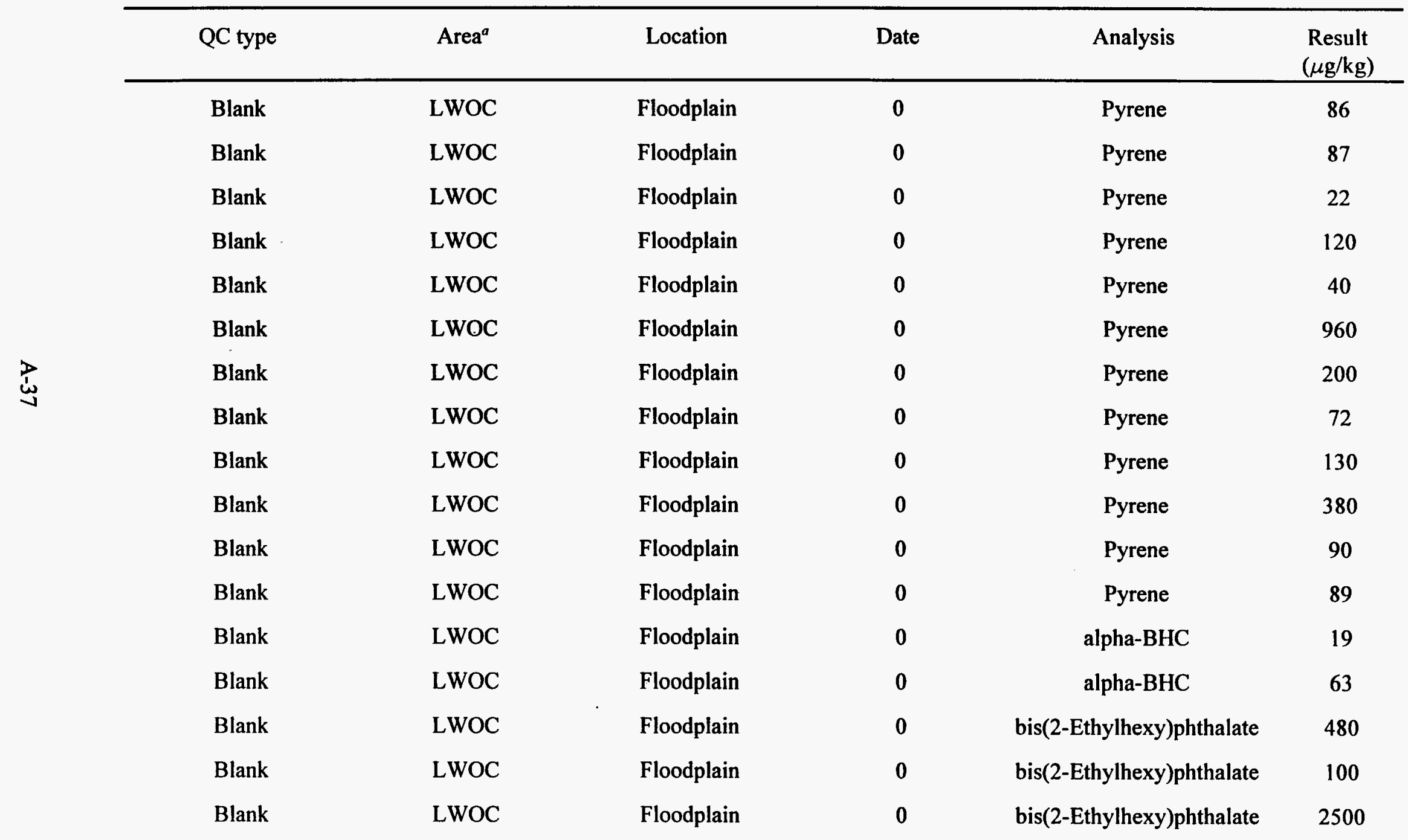


Table A.2 (continued)

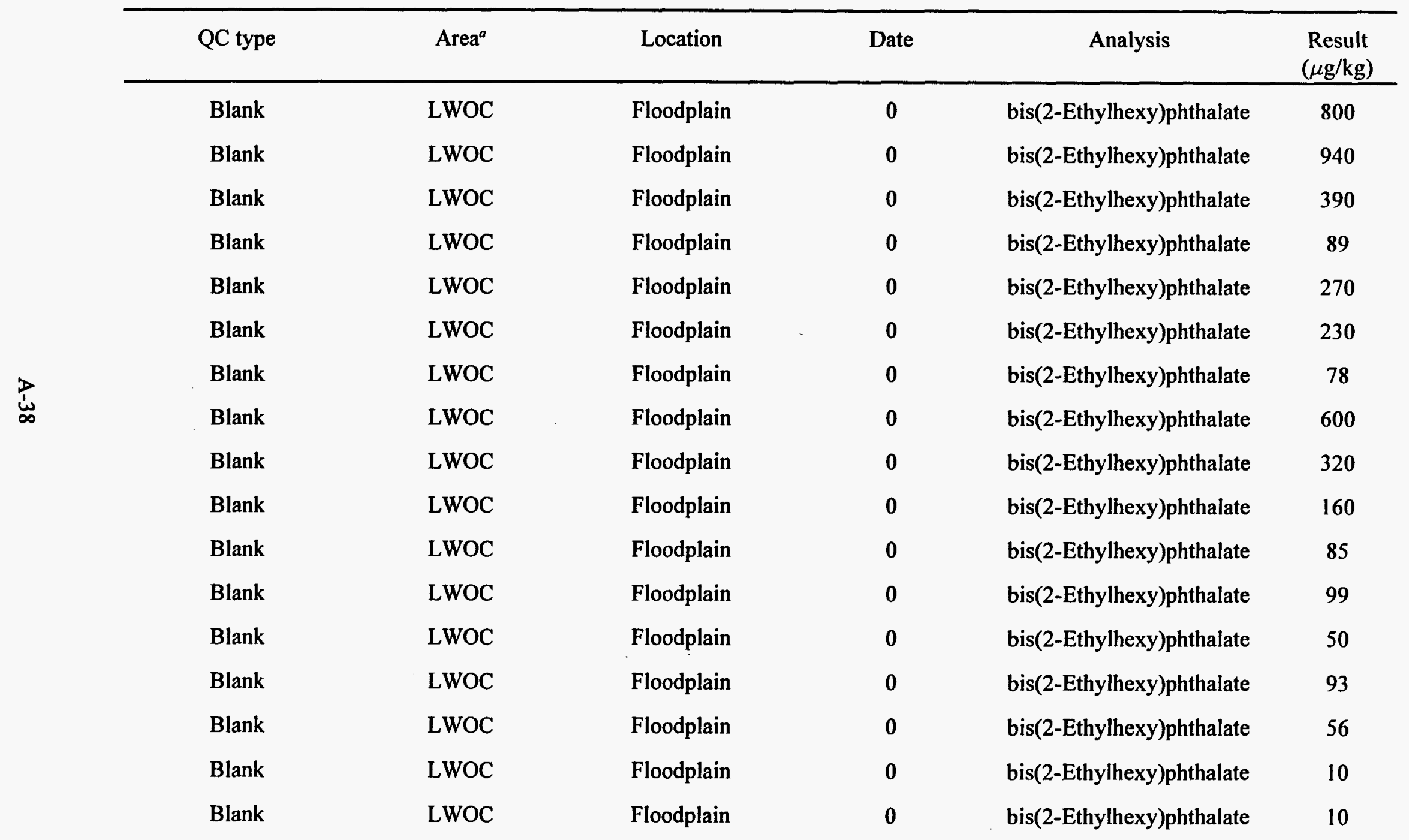


Table A.2 (continued)

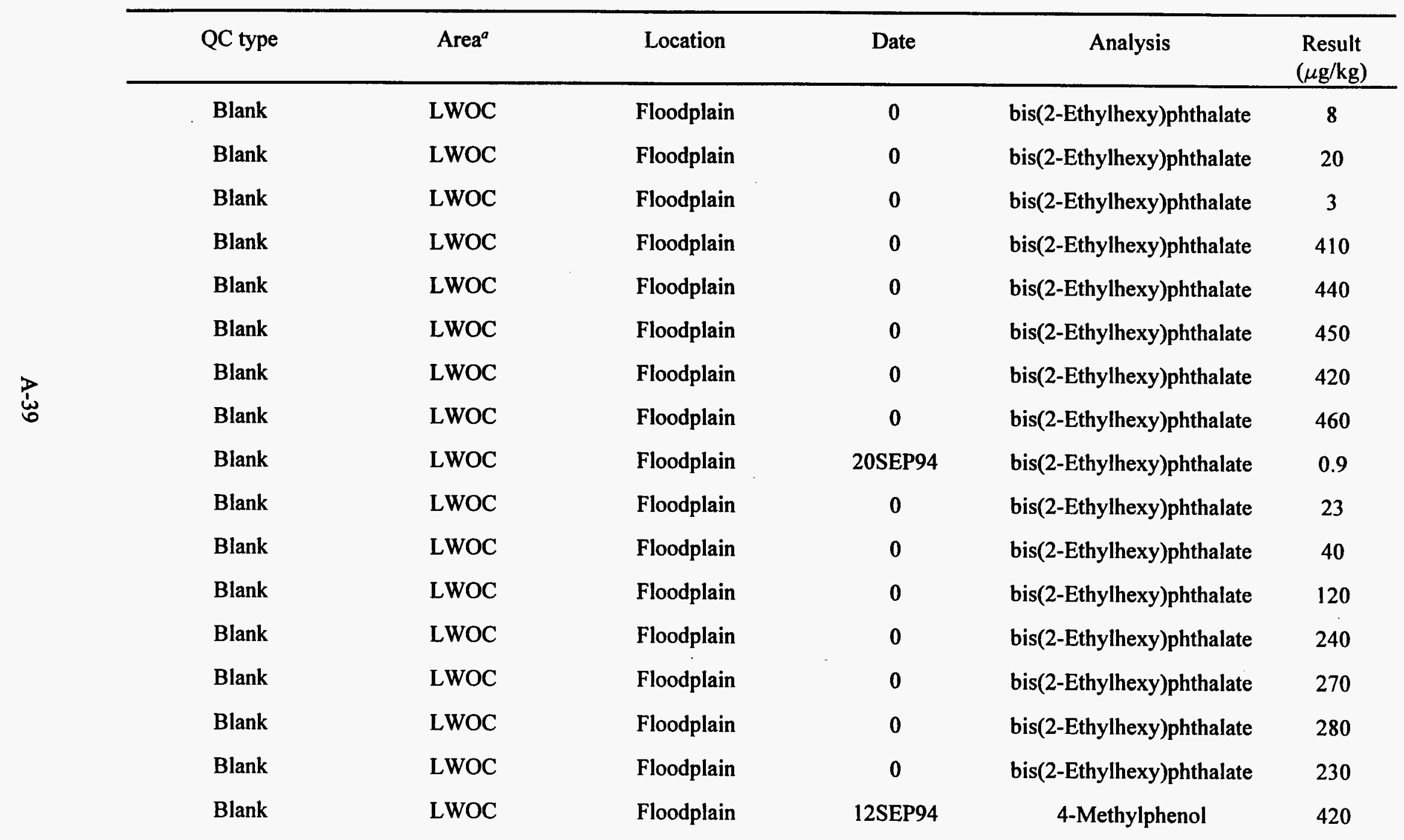


Table A.2 (continued)

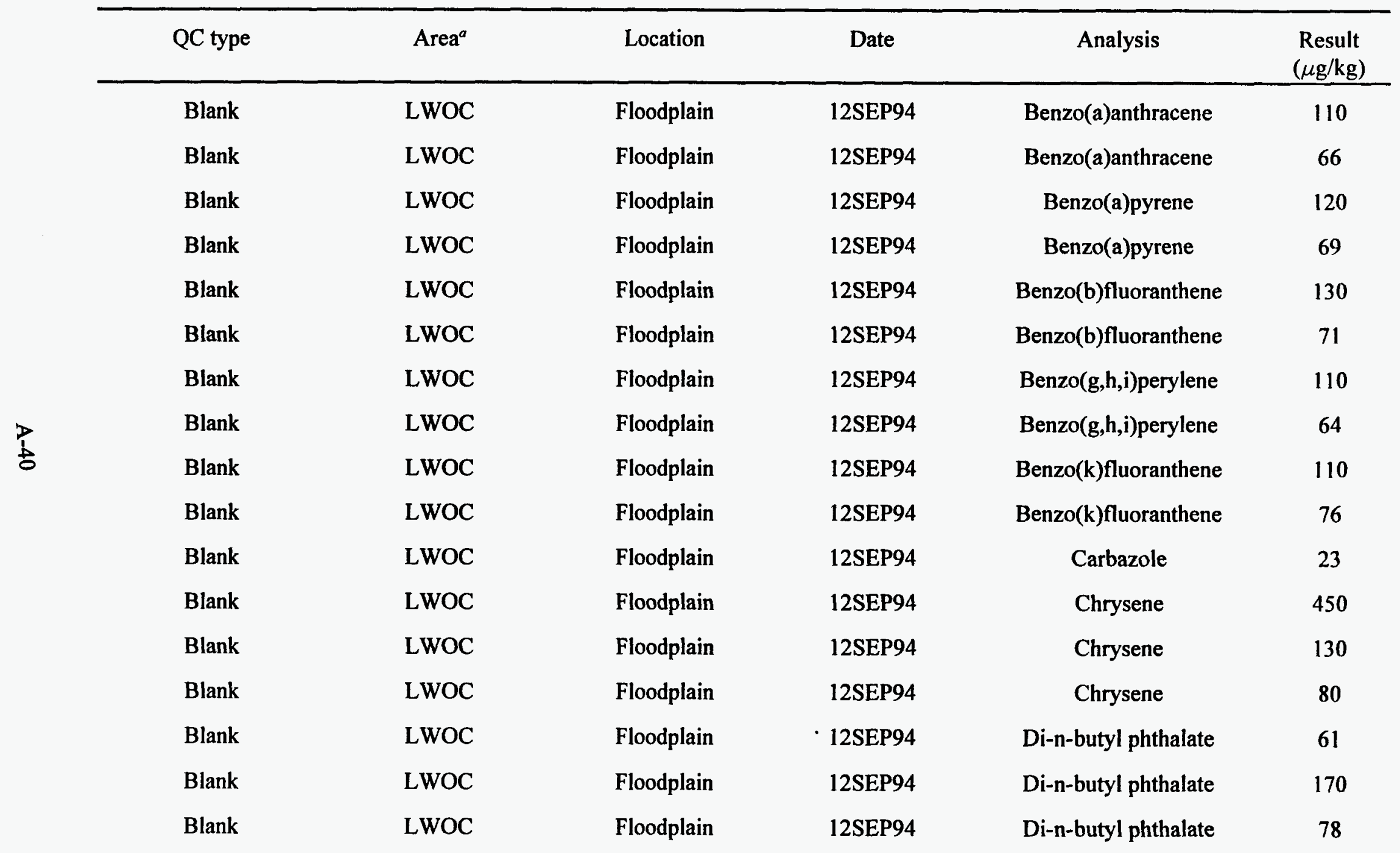


Table A.2 (continued)

\begin{tabular}{|c|c|c|c|c|c|}
\hline QC type & Area $^{a}$ & Location & Date & Analysis & $\begin{array}{l}\text { Result } \\
(\mu \mathrm{g} / \mathrm{kg})\end{array}$ \\
\hline Blank & LWOC & Floodplain & 12SEP94 & Dibenzo(a,h)anthracene & 46 \\
\hline Blank & LWOC & Floodplain & 12SEP94 & Dibenzo(a,h)anthracene & 25 \\
\hline Blank & LWOC & Floodplain & 12SEP94 & Fluoranthene & 25 \\
\hline Blank & LWOC & Floodplain & 12SEP94 & Fluoranthene & 200 \\
\hline Blank & LWOC & Floodplain & 12SEP94 & Fluoranthene & 130 \\
\hline Blank & LWOC & Floodplain & 12SEP94 & Indeno(1,2,3-cd)pyrene & 89 \\
\hline Blank & LWOC & Floodplain & 12SEP94 & Indeno(1,2,3-cd)pyrene & 56 \\
\hline Blank & LWOC & Floodplain & 12SEP94 & N-Nitrosodiphenylamine (1) & 420 \\
\hline Blank & LWOC & Floodplain & 12SEP94 & Phenanthrene & 120 \\
\hline Blank & LWOC & Floodplain & 12SEP94. & Phenanthrene & 57 \\
\hline Blank & LWOC & Floodplain & 12SEP94 & Pyrene & 30 \\
\hline Blank & LWOC & Floodplain & 12SEP94 & Pyrene & 230 \\
\hline Blank & LWOC & Floodplain & 12SEP94 & Pyrene & 140 \\
\hline Blank & LWOC & Floodplain & 12SEP94 & bis(2-Ethylhexyl)phthalate & 35 \\
\hline Blank & LWOC & Floodplain & 12SEP94 & bis(2-Ethylhexyl)phthalate & 79 \\
\hline Blank & LWOC & Floodplain & 12SEP94 & bis(2-Ethylhexyl)phthalate & 97 \\
\hline Blank & LWOC & Floodplain & 12SEP94 & bis(2-Ethylhexyl)phthalate & 64 \\
\hline
\end{tabular}


Table A.2 (continued)

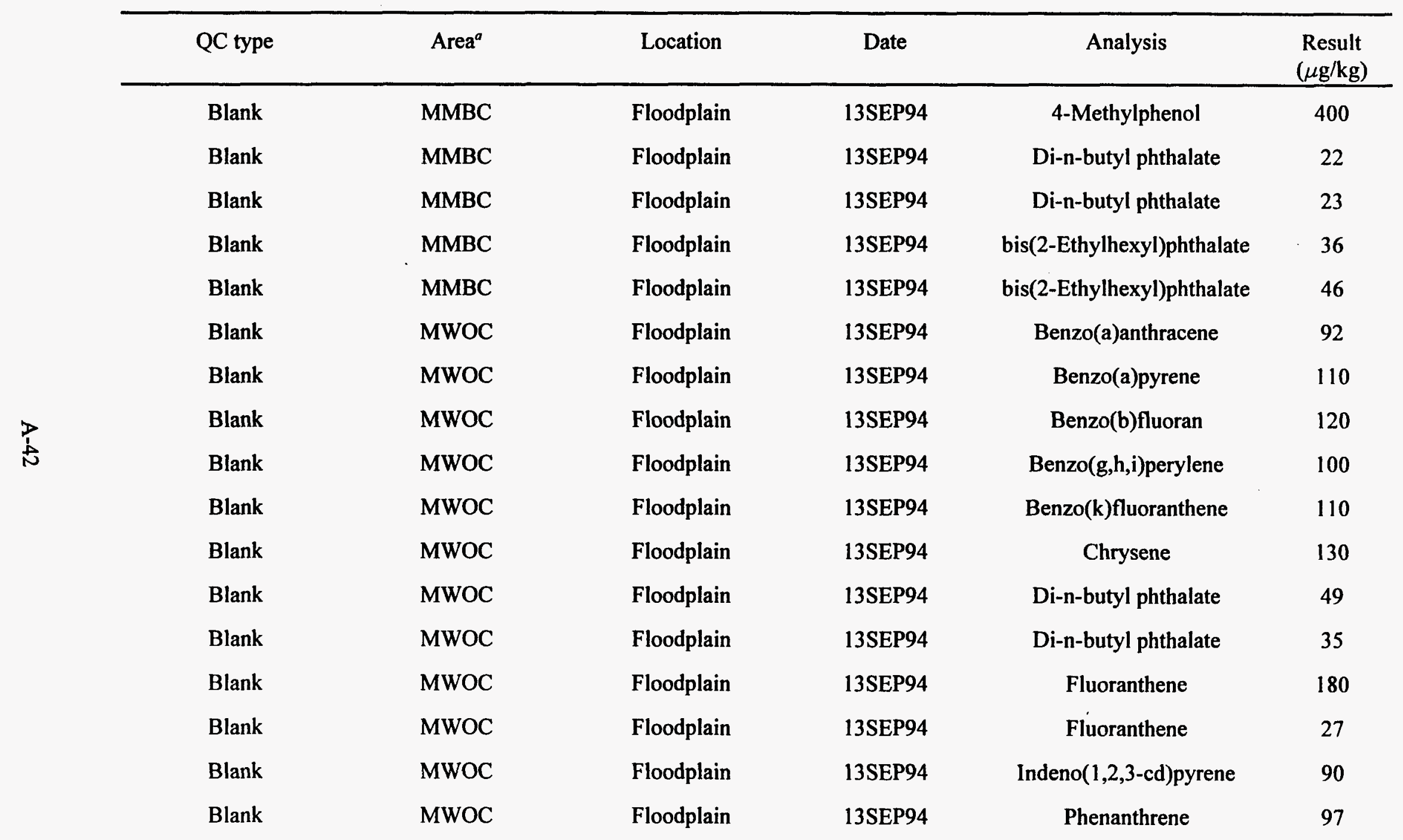


Table A.2 (continued)

\begin{tabular}{clllcc}
\hline QC type & Area $^{a}$ & Location & Date & Analysis & $\begin{array}{c}\text { Result } \\
(\mu \mathrm{g} / \mathrm{kg})\end{array}$ \\
\hline Blank & MWOC & Floodplain & 13 SEP94 & Pyrene & 220 \\
Blank & MWOC & Floodplain & 13 SEP94 & Pyrene & 34 \\
Blank & MWOC & Floodplain & 13 SEP94 & bis(2-Ethylhexyl)phthalate & 90 \\
Blank & MWOC & Floodplain & 13 SEP94 & bis(2-Ethylhexyl)phthalate & 43 \\
\hline
\end{tabular}

${ }^{a}$ LWOC $=$ Lower White Oak Creek; MMBC $=$ Middle Melton Branch Creek; MWOC $=$ Middle White Oak Creek 
Table A.3. Results of transuranic and beta soil samples submitted for quality control (QC) analysis

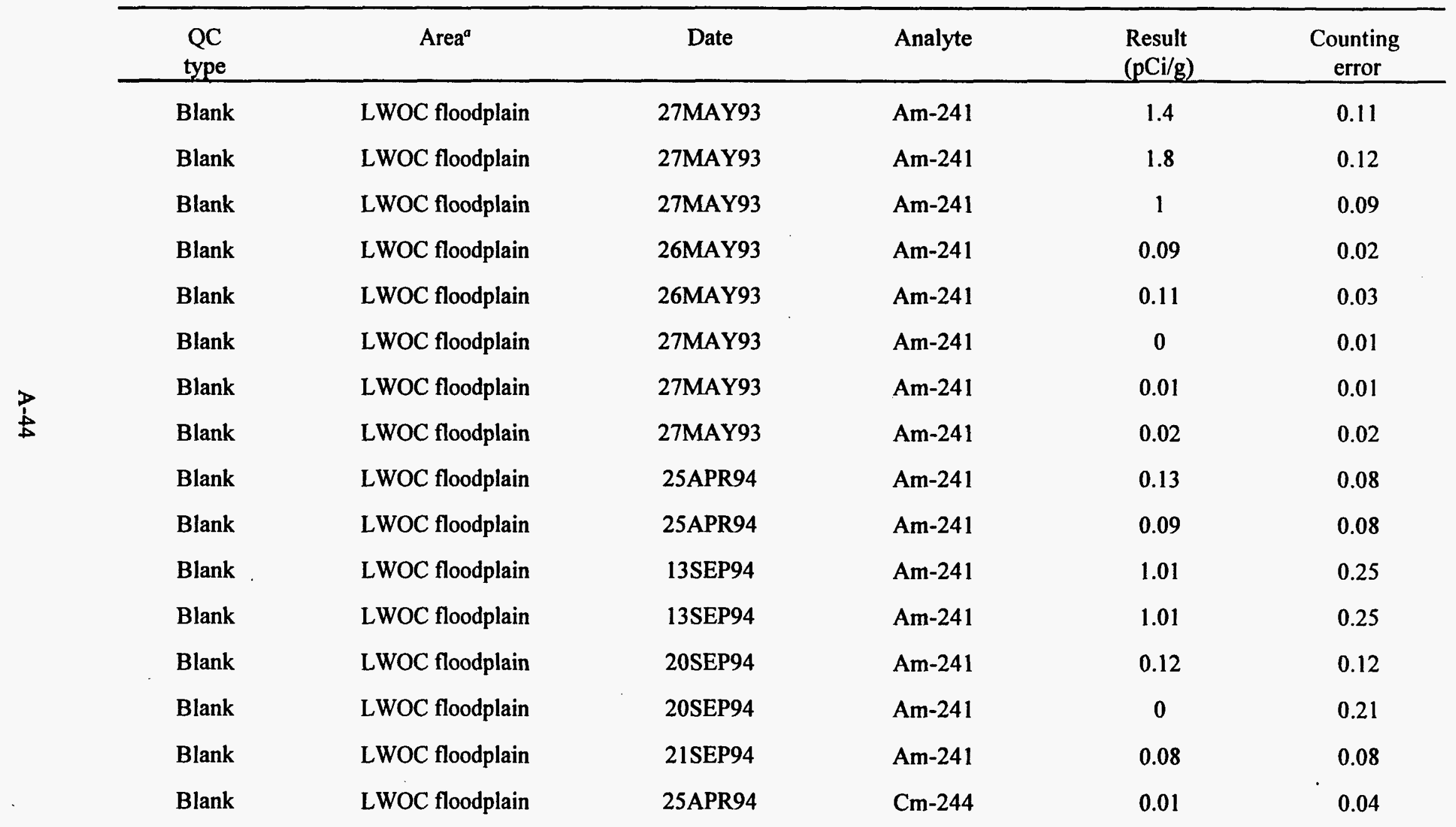


Table A.3 (continued)

\begin{tabular}{|c|c|c|c|c|c|}
\hline $\begin{array}{l}\mathrm{QC} \\
\text { type }\end{array}$ & Area $^{a}$ & Date & Analyte & $\begin{array}{r}\text { Result } \\
(\mathrm{pCi} / \mathrm{g})\end{array}$ & $\begin{array}{c}\text { Counting } \\
\text { error }\end{array}$ \\
\hline Blank & LWOC floodplain & 25APR94 & $\mathrm{Cm}-244$ & 0.01 & 0.02 \\
\hline Blank & LWOC floodplain & 13SEP94 & $\mathrm{Cm}-244$ & -0.01 & 0.03 \\
\hline Blank & LWOC floodplain & 13SEP94 & $\mathrm{Cm}-244$ & -0.01 & 0.03 \\
\hline Blank & LWOC floodplain & 20SEP94 & $\mathrm{Cm}-244$ & 0 & 0.09 \\
\hline Blank & LWOC floodplain & 20SEP94 & $\mathrm{Cm}-244$ & 0 & 0.21 \\
\hline Blank & LWOC floodplain & 21SEP94 & $\mathrm{Cm}-244$ & 0.02 & 0.07 \\
\hline Blank & LWOC floodplain & 27MAY93 & $\mathrm{Pu}-238$ & 0.18 & 0.04 \\
\hline Blank & LWOC floodplain & 27MAY93 & $\mathrm{Pu}-238$ & 0.4 & 0.05 \\
\hline Blank & LWOC floodplain & 27MAY93 & $\mathrm{Pu}-238$ & 0.21 & 0.04 \\
\hline Blank & LWOC floodplain & 26MAY93 & $\mathrm{Pu}-238$ & 0.01 & 0.01 \\
\hline Blank & LWOC floodplain & 26MAY93 & $\mathrm{Pu}-238$ & 0.01 & 0.01 \\
\hline Blank & LWOC floodplain & 25APR94 & $\mathrm{Pu}-238$ & 0.08 & 0.07 \\
\hline Blank & LWOC floodplain & 25APR94 & Pu-238 & 0.02 & 0.04 \\
\hline Blank & LWOC floodplain & 13SEP94 & Pu-238 & 0.04 & 0.05 \\
\hline Blank & LWOC floodplain & 13SEP94 & Pu-238 & 0.04 & 0.05 \\
\hline Blank & LWOC floodplain & 20SEP94 & Pu-238 & 0.02 & 0.06 \\
\hline Blank & LWOC floodplain & 20SEP94 & Pu-238 & -0.04 & 0.11 \\
\hline
\end{tabular}


Table A.3 (continued)

\begin{tabular}{|c|c|c|c|c|c|}
\hline $\begin{array}{l}\text { QC } \\
\text { type }\end{array}$ & Area $^{a}$ & Date & Analyte & $\begin{array}{r}\text { Result } \\
(\mathrm{pCi} / \mathrm{g})\end{array}$ & $\begin{array}{c}\text { Counting } \\
\text { error }\end{array}$ \\
\hline Blank & LWOC floodplain & 21SEP94 & $\mathrm{Pu}-238$ & 0.03 & 0.04 \\
\hline Blank & LWOC floodplain & 27MAY93 & $\mathrm{Pu}-239 / 240$ & 2.6 & 0.19 \\
\hline Blank & LWOC floodplain & 27MAY93 & $\mathrm{Pu}-239 / 240$ & 6.7 & 0.4 \\
\hline Blank & LWOC floodplain & 27MAY93 & $\mathrm{Pu}-239 / 240$ & 4.9 & 0.3 \\
\hline Blank & LWOC floodplain & 26MAY93 & $\mathrm{Pu}-239 / 240$ & 0.03 & 0.02 \\
\hline Blank & LWOC floodplain & 26MAY93 & $\mathrm{Pu}-239 / 240$ & 0.02 & 0.01 \\
\hline Blank & LWOC floodplain & 27MAY93 & $\mathrm{Pu}-239 / 240$ & 0.02 & 0.01 \\
\hline Blank & LWOC floodplain & 27MAY93 & $\mathrm{Pu}-239 / 240$ & 0.05 & 0.03 \\
\hline Blank & LWOC floodplain & 27MAY93 & $\mathrm{Pu}-239 / 240$ & 0.01 & 0.02 \\
\hline Blank & LWOC floodplain & 25APR94 & $\mathrm{Pu}-239 / 240$ & 0.14 & 0.08 \\
\hline Blank & LWOC floodplain & 25APR94 & $\mathrm{Pu}-239 / 240$ & 0.14 & 0.08 \\
\hline Blank & LWOC floodplain & 13SEP94 & $\mathrm{Pu}-239 / 240$ & 0.01 & 0.03 \\
\hline Blank & LWOC floodplain & 13SEP94 & $\mathrm{Pu}-239 / 240$ & 0.01 & 0.03 \\
\hline Blank & LWOC floodplain & 20SEP94 & $\mathrm{Pu}-239 / 240$ & 0.03 & 0.04 \\
\hline Blank & LWOC floodplain & 20SEP94 & $\mathrm{Pu}-239 / 240$ & 0.05 & 0.05 \\
\hline Blank & LWOC floodplain & 21SEP94 & Pu-239/240 & 0.04 & 0.04 \\
\hline
\end{tabular}


Table A.3 (continued)

\begin{tabular}{|c|c|c|c|c|c|}
\hline $\begin{array}{l}\mathrm{QC} \\
\text { type }\end{array}$ & Area $^{a}$ & Date & Analyte & $\begin{array}{l}\text { Result } \\
(\mathrm{pCi} / \mathrm{g})\end{array}$ & $\begin{array}{c}\text { Counting } \\
\text { error }\end{array}$ \\
\hline Blank & LWOC floodplain & 25APR94 & Sr-90 & 11.2 & 2 \\
\hline Blank & LWOC floodplain & 25APR94 & Sr-90 & 0.2 & 1.4 \\
\hline Blank & LWOC floodplain & 27MAY93 & Sr-90 & 7.4 & 0.77 \\
\hline Blank & LWOC floodplain & 27MAY93 & Sr-90 & 21 & 1.26 \\
\hline Blank & LWOC floodplain & 27MAY93 & Sr-90 & 33 & 1.37 \\
\hline Blank & LWOC floodplain & 26MAY93 & Sr-90 & 1 & 0.55 \\
\hline Blank & LWOC floodplain & 26MAY93 & Sr-90 & 0.57 & 0.55 \\
\hline Blank & LWOC floodplain & 27MAY93 & Sr-90 & 0.29 & 0.98 \\
\hline Blank & LWOC floodplain & 27MAY93 & Sr-90 & -0.13 & 1.17 \\
\hline Blank & LWOC floodplain & 27MAY93 & Sr-90 & -0.27 & 0.94 \\
\hline Blank & LWOC floodplain & 13SEP94 & Sr-90 & 0.29 & 0.79 \\
\hline Blank & LWOC floodplain & 13SEP94 & Sr-90 & 0.29 & 0.79 \\
\hline Blank & LWOC floodplain & 20SEP94 & Sr-90 & 0.36 & 0.84 \\
\hline Blank & LWOC floodplain & 20SEP94 & Sr-90 & -0.5 & 0.7 \\
\hline Blank & LWOC floodplain & 21SEP94 & Sr-90 & 0 & 0.72 \\
\hline Blank & LWOC floodplain & 13SEP94 & Tc-99 & 12 & 19 \\
\hline Blank & LWOC floodplain & 20SEP94 & Tc-99 & 4.7 & 8.8 \\
\hline
\end{tabular}


Table A.3 (continued)

\begin{tabular}{|c|c|c|c|c|c|}
\hline $\begin{array}{c}\mathrm{QC} \\
\text { type }\end{array}$ & Area $^{a}$ & Date & Analyte & $\begin{array}{l}\text { Result } \\
(\mathrm{pCi} / \mathrm{g})\end{array}$ & $\begin{array}{c}\text { Counting } \\
\text { error }\end{array}$ \\
\hline Blank & LWOC floodplain & 20SEP94 & Tc-99 & 0 & 3.1 \\
\hline Blank & LWOC floodplain & 21SEP94 & Tc-99 & 17.3 & 5.4 \\
\hline Blank & LWOC floodplain & 27MAY93 & Th-228 & 2 & 0.31 \\
\hline Blank & LWOC floodplain & 27MAY93 & Th-228 & 1.5 & 0.28 \\
\hline Blank & LWOC floodplain & 27MAY93 & Th-228 & 1.2 & 0.23 \\
\hline Blank & LWOC floodplain & 26MAY93 & Th-228 & 6.4 & 0.79 \\
\hline Blank & LWOC floodplain & 26MAY93 & Th-228 & 6 & 0.83 \\
\hline Blank & LWOC floodplain & 27MAY93 & Th-228 & 0.04 & 0.11 \\
\hline Blank & LWOC floodplain & 27ṂAY93 & Th-228 & 0.01 & 0.11 \\
\hline Blank & LWOC floodplain & 27MAY93 & Th-228 & 0.08 & 0.15 \\
\hline Blank & LWOC floodplain & 25APR94 & Th-228 & 0.13 & 0.33 \\
\hline Blank & LWOC floodplain & 25APR94 & Th-228 & -0.1 & 0.27 \\
\hline Blank & LWOC floodplain & 13SEP94 & Th-228 & 9.95 & 0.91 \\
\hline Blank & LWOC floodplain & 13SEP94 & Th-228 & 9.95 & 0.91 \\
\hline Blank & LWOC floodplain & 20SEP94 & Th-228 & 9.99 & 0.85 \\
\hline Blank & LWOC floodplain & 20SEP94 & Th-228 & 14.9 & 1.2 \\
\hline
\end{tabular}


Table A. 3. (continued)

\begin{tabular}{|c|c|c|c|c|c|}
\hline $\begin{array}{l}\mathrm{QC} \\
\text { type }\end{array}$ & Area $^{a}$ & Date & Analyte & $\begin{array}{r}\text { Result } \\
(\mathrm{pCi} / \mathrm{g})\end{array}$ & $\begin{array}{c}\text { Counting } \\
\text { error }\end{array}$ \\
\hline Blank & LWOC floodplain & 21SEP94 & Th-228 & 7.92 & 0.77 \\
\hline Blank & LWOC floodplain & 27MAY93 & Th-230 & 1.1 & 0.21 \\
\hline Blank & LWOC floodplain & 27MAY93 & Th-230 & 1.2 & 0.23 \\
\hline Blank & LWOC floodplain & 27MAY93 & Th-230 & 0.95 & 0.2 \\
\hline Blank & LWOC floodplain & 26MAY93 & Th-230 & 1.2 & 0.25 \\
\hline Blank & LWOC floodplain & 26MAY93 & Th-230 & 1 & 0.25 \\
\hline Blank & LWOC floodplain & 27MAY93 & Th-230 & 0.2 & 0.13 \\
\hline Blank & LWOC floodplain & 27MAY93 & Th-230 & 0.53 & 0.2 \\
\hline Blank & LWOC floodplain & 27MAY93 & Th-230 & 0.27 & 0.15 \\
\hline Blank & LWOC floodplain & 25APR94 & Th-230 & 0.98 & 0.69 \\
\hline Blank & LWOC floodplain & 25APR94 & Th-230 & 0.76 & 0.59 \\
\hline Blank & LWOC floodplain & 13SEP94 & Th-230 & 1.83 & 0.33 \\
\hline Blank & LWOC floodplain & 13SEP94 & Th-230 & 1.83 & 0.33 \\
\hline Blank & LWOC floodplain & 20SEP94 & Th-230 & 1.03 & 0.22 \\
\hline Blank & LWOC floodplain & 20SEP94 & Th-230 & 0.8 & 0.23 \\
\hline Blank & LWOC floodplain & 21SEP94 & Th-230 & 1.98 & 0.34 \\
\hline Blank & LWOC floodplain & 27MAY93 & Th-232 & 1.2 & 0.23 \\
\hline
\end{tabular}


Table A.3 (continued)

\begin{tabular}{|c|c|c|c|c|c|}
\hline $\begin{array}{c}\text { QC } \\
\text { type }\end{array}$ & Area $^{a}$ & Date & Analyte & $\begin{array}{l}\text { Result } \\
(\mathrm{pCi} / \mathrm{g})\end{array}$ & $\begin{array}{c}\text { Counting } \\
\text { error } \\
\end{array}$ \\
\hline Blank & LWOC floodplain & 27MAY93 & Th-232 & 1.1 & 0.23 \\
\hline Blank & LWOC floodplain & 27MAY93 & Th-232 & 1.3 & 0.23 \\
\hline Blank & LWOC floodplain & 26MAY93 & Th-232 & 1.1 & 0.23 \\
\hline Blank & LWOC floodplain & 26MAY93 & Th-232 & 1.5 & 0.31 \\
\hline Blank & LWOC floodplain & 27MAY93 & Th-232 & 0.07 & 0.08 \\
\hline Blank & LWOC floodplain & 27MAY93 & Th-232 & 0.08 & 0.09 \\
\hline Blank & LWOC floodplain & 27MAY93 & Th-232 & 0.03 & 0.06 \\
\hline Blank & LWOC floodplain & 25APR94 & Th-232 & 0.42 & 0.29 \\
\hline Blank & LWOC floodplain & 25APR94 & Th-232 & 0.31 & 0.23 \\
\hline Blank & LWOC floodplain & 13SEP94 & Th-232 & 0.27 & 0.14 \\
\hline Blank & LWOC floodplain & 13SEP94 & Th-232 & 0.27 & 0.14 \\
\hline Blank & LWOC floodplain & 20SEP94 & Th-232 & 0.15 & 0.08 \\
\hline Blank & LWOC floodplain & 20SEP94 & Th-232 & 0.11 & 0.09 \\
\hline Blank & LWOC floodplain & 21SEP94 & Th-232 & 0.45 & 0.16 \\
\hline Blank & LWOC floodplain & 27MAY93 & $U-233 / 234$ & 1.4 & 0.22 \\
\hline Blank & LWOC floodplain & 27MAY93 & $\mathrm{U}-233 / 234$ & 2.1 & 0.29 \\
\hline
\end{tabular}


Table A.3 (continued)

\begin{tabular}{|c|c|c|c|c|c|}
\hline $\begin{array}{l}\mathrm{QC} \\
\text { type }\end{array}$ & Area $^{a}$ & Date & Analyte & $\begin{array}{l}\text { Result } \\
(\mathrm{pCi} / \mathrm{g})\end{array}$ & $\begin{array}{c}\text { Counting } \\
\text { error } \\
\end{array}$ \\
\hline Blank & LWOC floodplain & 27MAY93 & $U-233 / 234$ & 2.5 & 0.33 \\
\hline Blank & LWOC floodplain & 26MAY93 & U-233/234 & 8.5 & 0.84 \\
\hline Blank & LWOC floodplain & 26MAY93 & $\mathrm{U}-233 / 234$ & 5.4 & 0.54 \\
\hline Blank & LWOC floodplain & 27MAY93 & $\mathrm{U}-233 / 234$ & 0.46 & 0.29 \\
\hline Blank & LWOC floodplain & 27MAY93 & $\mathrm{U}-233 / 234$ & 0.05 & 0.13 \\
\hline Blank & LWOC floodplain & 27MAY93 & $\mathrm{U}-233 / 234$ & 0.24 & 0.24 \\
\hline Blank & LWOC floodplain & 25APR94 & $U-233 / 234$ & 0.51 & 0.32 \\
\hline Blank & LWOC floodplain & 25APR94 & $U-233 / 234$ & 1.36 & 0.51 \\
\hline Blank & LWOC floodplain & 13SEP94 & $\mathrm{U}-233 / 234$ & 0.29 & 0.12 \\
\hline Blank & LWOC floodplain & 13SEP94 & $\mathrm{U}-233 / 234$ & 0.29 & 0.12 \\
\hline Blank & LWOC floodplain & 20SEP94 & $\mathrm{U}-233 / 234$ & 0.47 & 0.15 \\
\hline Blank & LWOC floodplain & 20SEP94 & $\mathrm{U}-233 / 234$ & 0.76 & 0.2 \\
\hline Blank & LWOC floodplain & 21SEP94 & $\mathrm{U}-233 / 234$ & 0.41 & 0.15 \\
\hline Blank & LWOC floodplain & 27MAY93 & $\mathrm{U}-235$ & 0.06 & 0.04 \\
\hline Blank & LWOC floodplain & 27MAY93 & $\mathrm{U}-235$ & 0.05 & 0.04 \\
\hline Blank & LWOC floodplain & 27MAY93 & $\mathrm{U}-235$ & 0.07 & 0.04 \\
\hline Blank & LWOC floodplain & 26MAY93 & $\mathrm{U}-235$ & 0.1 & 0.06 \\
\hline
\end{tabular}


Table A.3 (continued)

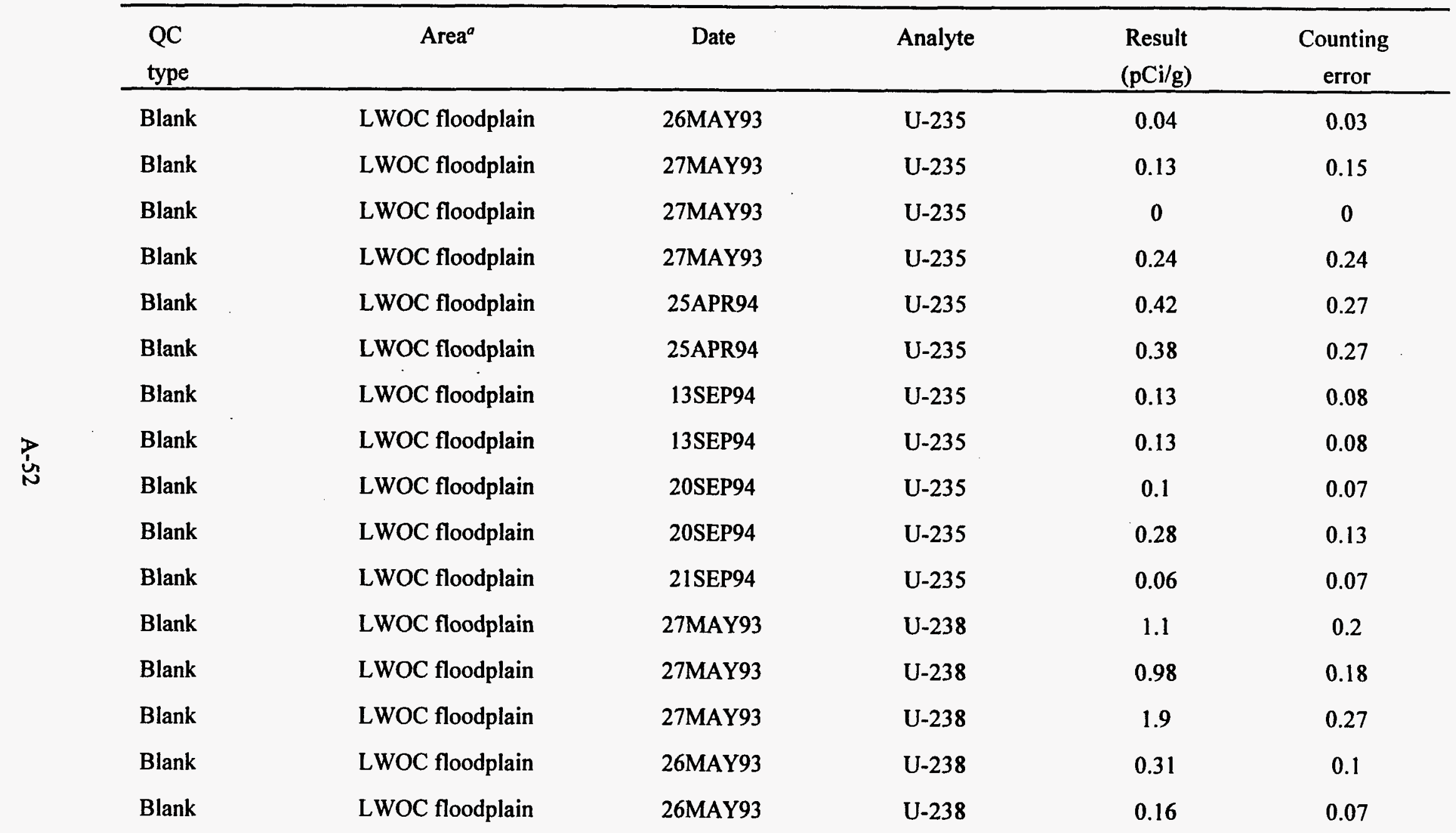




$$
\begin{aligned}
& \text { | }
\end{aligned}
$$

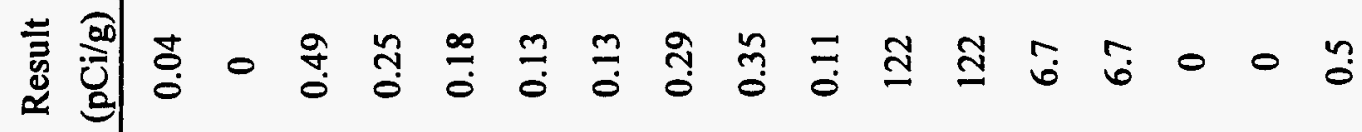

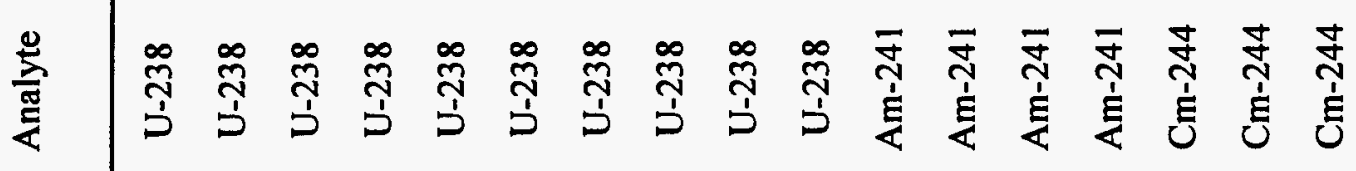

$$
\begin{aligned}
& \text { 急 }
\end{aligned}
$$

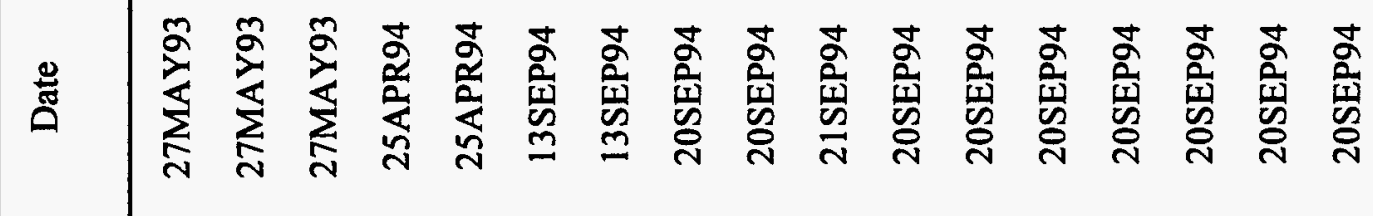

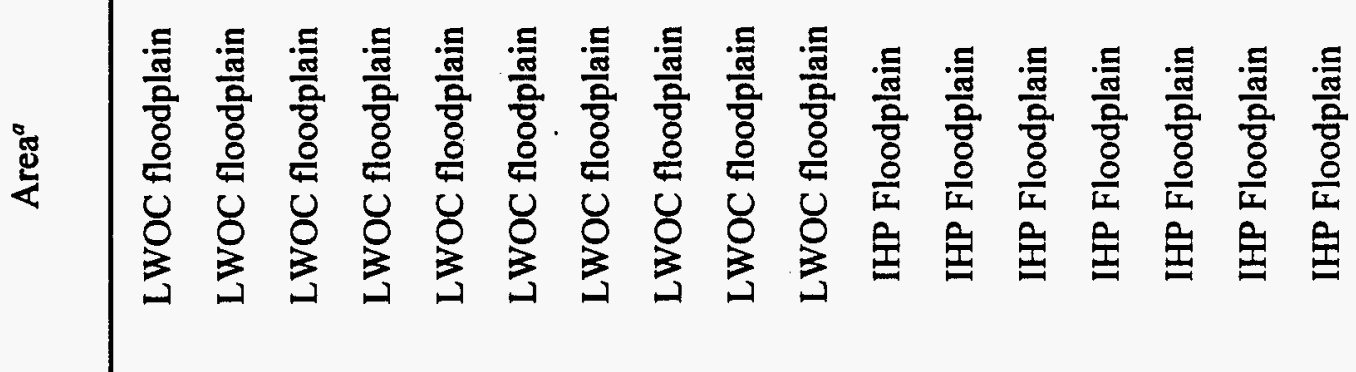

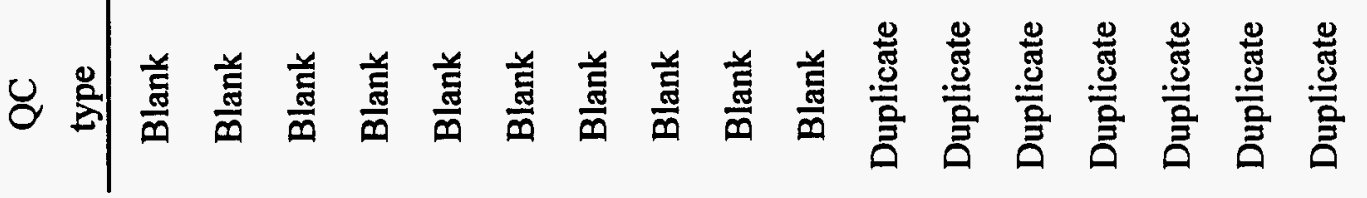




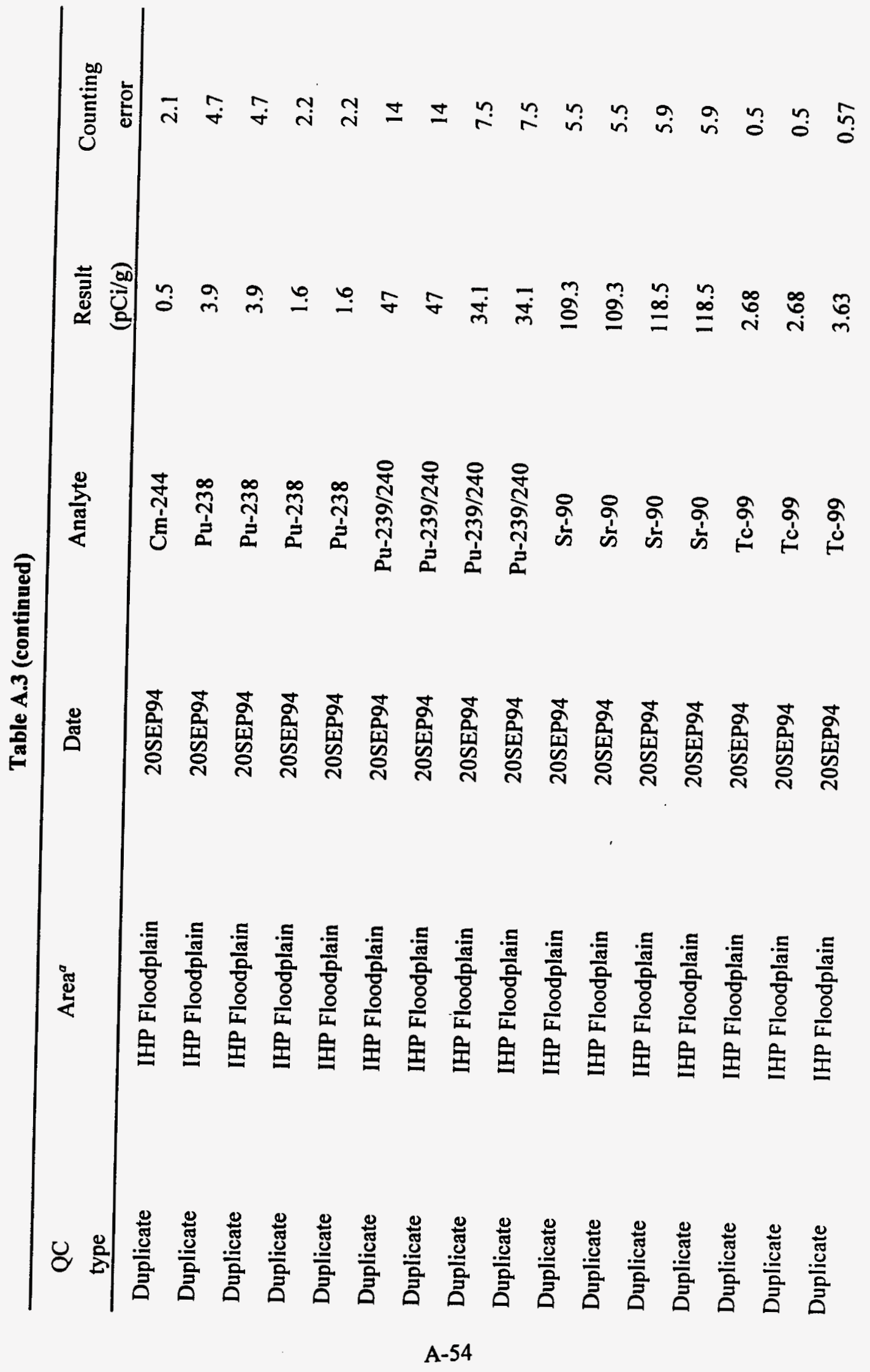


Table A.3 (continued)

\begin{tabular}{|c|c|c|c|c|c|}
\hline $\begin{array}{l}\text { QC } \\
\text { type }\end{array}$ & Area $^{a}$ & Date & Analyte & $\begin{array}{c}\text { Result } \\
(\mathrm{pCi} / \mathrm{g})\end{array}$ & $\begin{array}{c}\text { Counting } \\
\text { error } \\
\end{array}$ \\
\hline Duplicate & IHP Floodplain & 20SEP94 & Tc-99 & 3.63 & 0.57 \\
\hline Duplicate & IHP Floodplain & 20SEP94 & Th-228 & 17 & 18 \\
\hline Duplicate & IHP Floodplain & 20SEP94 & Th-228 & 17 & 18 \\
\hline Duplicate & IHP Floodplain & 20SEP94 & Th-228 & 5.3 & 8.9 \\
\hline Duplicate & IHP Floodplain & 20SEP94 & Th-228 & 5.3 & 8.9 \\
\hline Duplicate & IHP Floodplain & 20SEP94 & Th-230 & 29 & 12 \\
\hline Duplicate & IHP Floodplain & 20SEP94 & Th-230 & 29 & 12 \\
\hline Duplicate & IHP Floodplain & 20SEP94 & Th-230 & 32.1 & 8.4 \\
\hline Duplicate & IHP Floodplain & 20SEP94 & Th-230 & 32.1 & 8.4 \\
\hline Duplicate & IHP Floodplain & 20SEP94 & Th-232 & 10.2 & 7.7 \\
\hline Duplicate & IHP Floodplain & 20SEP94 & Th-232 & 10.2 & 7.7 \\
\hline Duplicate & IHP Floodplain & 20SEP94 & Th-232 & 0.8 & 2.4 \\
\hline Duplicate & IHP Floodplain & 20SEP94 & Th-232 & 0.8 & 2.4 \\
\hline Duplicate & IHP Floodplain & 20SEP94 & U-233/234 & 30 & 20 \\
\hline Duplicate & IHP Floodplain & 20SEP94 & U-233/234 & 60 & 25 \\
\hline Duplicate & IHP Floodplain & 20SEP94 & $\mathrm{U}-235$ & -1 & 1.5 \\
\hline Duplicate & IHP Floodplain & 20SEP94 & U-235 & 13 & 11 \\
\hline
\end{tabular}


Table A.3 (continued)

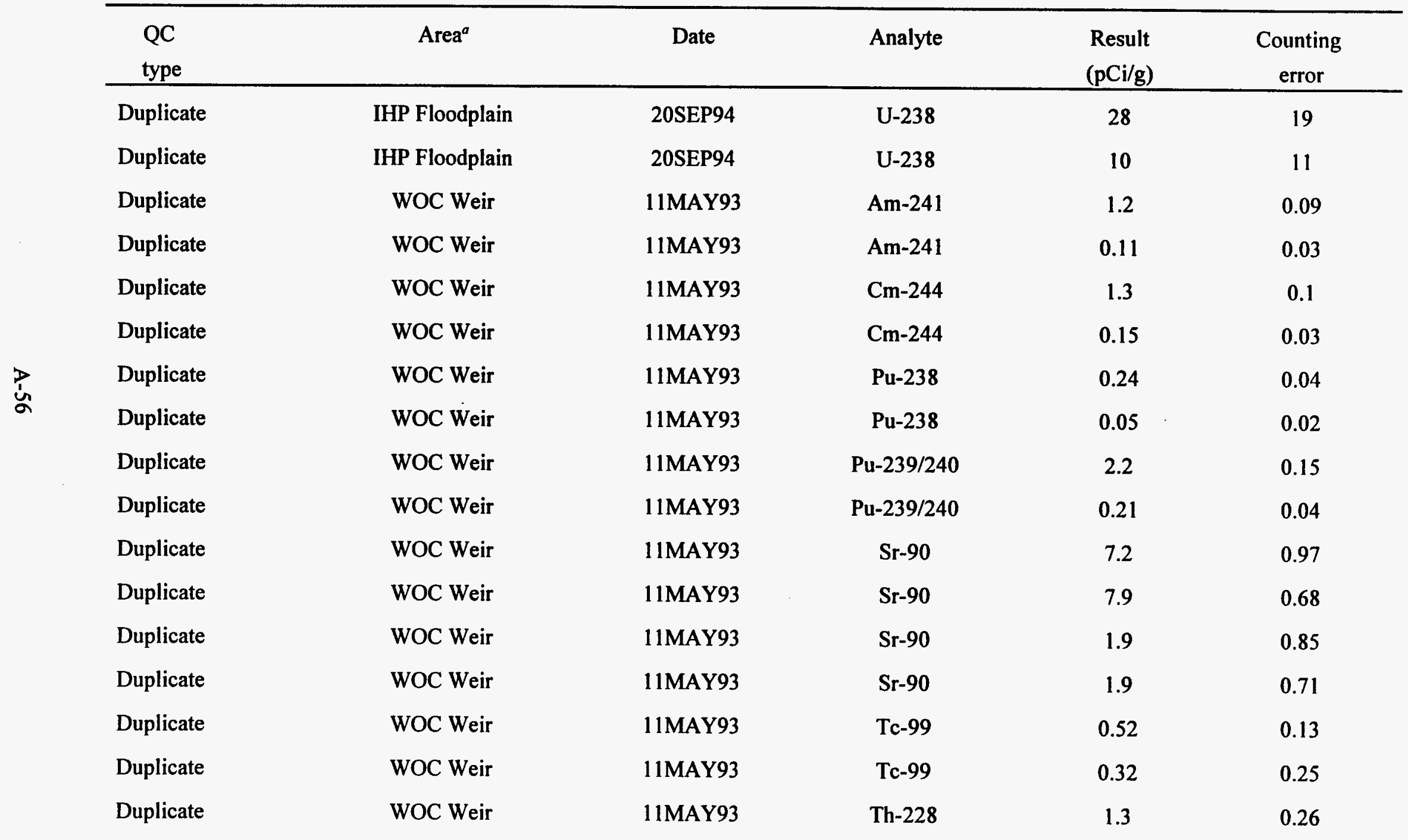


Table A.3 (continued)

\begin{tabular}{|c|c|c|c|c|c|}
\hline $\begin{array}{l}\mathrm{QC} \\
\text { type }\end{array}$ & Area $^{a}$ & Date & Analyte & $\begin{array}{c}\text { Result } \\
(\mathrm{pCi} / \mathrm{g})\end{array}$ & $\begin{array}{c}\text { Counting } \\
\text { error }\end{array}$ \\
\hline Duplicate & WOC Weir & 11MAY93 & Th-228 & 0.38 & 0.12 \\
\hline Duplicate & WOC Weir & 11MAY93 & Th-230 & 1.1 & 0.23 \\
\hline Duplicate & WOC Weir & 11MAY93 & Th-230 & 0.5 & 0.13 \\
\hline Duplicate & WOC Weir & 11MAY93 & Th-232 & 1 & 0.22 \\
\hline Duplicate & WOC Weir & 11MAY93 & Th-232 & 0.54 & 0.13 \\
\hline Duplicate & WOC Weir & 11MAY93 & U-233/234 & 2.5 & 0.37 \\
\hline Duplicate & WOC Weir & 11MAY93 & U-233/234 & 0.59 & 0.14 \\
\hline Duplicate & WOC Weir & 11MAY93 & $\mathrm{U}-235$ & 0.03 & 0.04 \\
\hline Duplicate & WOC Weir & $11 \mathrm{MAY} 93$ & $\mathrm{U}-235$ & 0.03 & 0.03 \\
\hline Duplicate & WOC Weir & $11 \mathrm{MAY} 93$ & $\mathrm{U}-238$ & 1.3 & 0.25 \\
\hline Duplicate & WOC Weir & $11 \mathrm{MAY} 93$ & $U-238$ & 0.49 & 0.13 \\
\hline
\end{tabular}

${ }^{\circ} \mathrm{IHP}=$ Intermediate Holding Pond; LWOC $=$ Lower White Oak Creek; WOC $=$ White Oak Creek 


\section{APPENDIX B}

SUMMARY OF RESULTS FROM SOIL AND SEDIMENT SAMPLES FROM THE WAG 2 FLOODPLAIN 
Table B.1. Summary of gamma values for Waste Area Grouping 2 floodplain soil and stream sediments

\begin{tabular}{|c|c|c|c|c|c|c|c|}
\hline $\begin{array}{c}\text { Location }^{a} \\
\text { (multiple } F \text { test results) }\end{array}$ & $\begin{array}{c}\text { Area }^{\circ} \\
\text { (multiple } F^{\text {test results) }}{ }^{b}\end{array}$ & $\begin{array}{c}\text { Type } \\
\text { (multiple } F \text { test }^{\text {results) }}\end{array}$ & $\begin{array}{l}\text { No. of } \\
\text { observa- } \\
\text { tions }\end{array}$ & $\begin{array}{l}\text { Maximum } \\
(\mathrm{pCi} / \mathrm{g})\end{array}$ & $\underset{(\mathrm{pCi} / \mathrm{g})}{\text { Minimum }}$ & $\begin{array}{c}\text { Mean } \\
(\mathrm{pCi} / \mathrm{g})\end{array}$ & $\begin{array}{c}\mathrm{SD} \\
(\mathrm{pCi} / \mathrm{g})\end{array}$ \\
\hline \multicolumn{8}{|c|}{ Cobalt -60} \\
\hline West Seep (BC) & LWOC (C) & $\operatorname{Seep~(A)~}$ & 17 & 67.06 & 10.3 & 35.38 & 14.88 \\
\hline Reach 3 Floodplain (C) & LWOC (C) & Floodplain (C) & 272 & 42 & 1.88 & 6.68 & 6.96 \\
\hline East Seep (A) & LWOC (C) & Seep (A) & 28 & 338.52 & 42.88 & 194.28 & 63.16 \\
\hline WOC Weir (BC) & MWOC (C) & Weir (B) & 74 & 41 & 1.39 & 5.26 & 8.45 \\
\hline WOC Floodplain (C) & MWOC (C) & Floodplain (C) & 34 & 3.1 & - 1.73 & 2.13 & 0.36 \\
\hline Lower Melton Branch Weir (A) & $\operatorname{LMBC}(\mathrm{A})$ & Weir (B) & 92 & 408.92 & 1.65 & 34.33 & 71.1 \\
\hline Melton Branch Floodplain (B) & MMBC (B) & Floodplain (C) & 40 & 1460.81 & 1.7 & 73.84 & 314.54 \\
\hline Upper Melton Branch Weir (A) & UMBC (A) & Weir (B) & 13 & 342.02 & 9.45 & 164.67 & 78.92 \\
\hline IHP Floodplain (BC) & $\operatorname{IHP}(C)$ & Floodplain (C) & 306 & 138.77 & 1.72 & 8.88 & 18.08 \\
\hline 7500 Weir (BC) & IHP (C) & Weir (B) & 36 & 216.98 & 2.65 & 26.31 & 50.63 \\
\hline WAG4 T2A (BC) & IHP (C) & Seep (A) & 13 & 91.9 & 3.99 & 19.05 & 23.76 \\
\hline \multicolumn{8}{|c|}{ Cesium-137 } \\
\hline West Seep (B) & LWOC (B) & Seep (B) & 17 & 5.81 & 1.48 & 2.67 & 1.01 \\
\hline Reach 3 Floodplain (AB) & LWOC (B) & Floodplain (A) & 272 & 9490.4 & 0.87 & 687.3 & 1714.3 \\
\hline East Seep (B) & LWOC (B) & Seep (B) & 28 & 40.89 & 1.92 & 12.23 & 9.1 \\
\hline WOC Weir (AB) & MWOC (B) & Weir (A) & 74 & 9767.5 & 2.05 & 546.54 & 1442.15 \\
\hline wOC Floodplain (AB) & MWOC (B) & Floodplain (A) & 34 & 1550.65 & 0.83 & 257.23 & 432.25 \\
\hline Lower Melton Branch Weir (B) & LMBC (B) & Weir (A) & 92 & 3377.26 & 0.82 & 450.06 & 668.41 \\
\hline Melton Branch Floodplain (B) & MMBC (B) & Floodplain (A) & 40 & 33.84 & 0.79 & 6.39 & 8.22 \\
\hline Upper Melton Branch Weir (B) & UMBC (B) & Weir (A) & 13 & 4.54 & 1.53 & 2.78 & 0.75 \\
\hline IHP Floodplain (A) & IHP (A) & Floodplain (A) & 306 & 52438.32 & 0.8 & 4567.46 & 8464.84 \\
\hline 7500 Weir $(A B)$ & $\operatorname{IHP}(A)$ & Weir (A) & 36 & 29670.5 & 1.54 & 3506.67 & 5669.6 \\
\hline WAG4 T2A (AB) & IHP (A) & Seep (B) & 13 & 4264.3 & 11.54 & 1445.49 & 1515 \\
\hline
\end{tabular}

${ }^{\text {IHP }}=$ Intermediate Holding Pond; LMBC = Lower Melton Branch Creek; LWOC = Lower White Oak Creek; MMBC = Middle Melton Branch Creek; MWOC = Middle White Oak Creek; UMBC $=$ Upper Melton Branch Creek.

${ }^{b}$ Letters in parentheses (e.g., A, B, C) indicate relative significance of mean values. Means for entries with the same letter are not significantly different ( $\left.p>0.05\right)$. 
Table B.2. Summary of transuranic and beta values for Waste Area Grouping 2 noodplain soil and sediment

\begin{tabular}{|c|c|c|c|c|c|c|c|c|}
\hline Analysis & $\begin{array}{l}\text { Location }^{a} \\
\text { (multiple } F \text { test } \\
\text { results) }\end{array}$ & $\begin{array}{c}\text { Area" } \\
\text { (multiple F } \\
\text { test results) }\end{array}$ & $\begin{array}{c}\text { Type } \\
\text { (multiple } F \text { test } \\
\text { results) }\end{array}$ & $\begin{array}{l}\text { Number of } \\
\text { observations }\end{array}$ & $\begin{array}{l}\text { Maximum } \\
(\mathrm{pCi} / \mathrm{g})\end{array}$ & $\begin{array}{l}\text { Minimum } \\
(\mathrm{pCi} / \mathrm{g})\end{array}$ & $\begin{array}{l}\text { Mean } \\
(\mathrm{pCi} / \mathrm{g})\end{array}$ & $\underset{(p \mathrm{Pi} / \mathrm{g})}{S D}$ \\
\hline Am-241 & West Seep & LWOC & Seep & $\cdot 2$ & 9.4 & 1 & 5.2 & 5.94 . \\
\hline Am-241 & Floodplain & LWOC & Floodplain & 20 & 13.1 & 0 & 2.12 & 3.71 \\
\hline Am-241 & WOC Weir & MWOC & Weir & 5 & 3.2 & 0.11 & 1.8 & 1.22 \\
\hline Am-241 & Floodplain & MWOC & Floodplain & 3 & 4 & 1.25 & 2.32 & 1.47 \\
\hline Am-241 & MB Weir & LMBC & Weir & 3 & 0.13 & 0.04 & 0.07 & 0.05 \\
\hline Am-241 & Floodplain & MMBC & Floodplain & 2 & 6.2 & 0.1 & 3.15 & 4.31 \\
\hline Am-241 & Seep C & MMBC & Seep & 5 & 1.59 & 0.04 & 0.88 & 0.73 \\
\hline Am-241 & MB2 Weir & UMBC & Weir. & 2 & 0.03 & 0.02 & 0.03 & 0.01 \\
\hline Am-241 & Floodplain (IHP) & IHP & Floodplain & 20 & 122 & -0.48 & 25.45 & 36.9 \\
\hline Am-241 & WAG4 T2A & IHP & Seep & 3 & 6.16 & 1.7 & 3.25 & 2.52 \\
\hline Cm-244 & West Seep & LWOC & Seep & 2 & 0.06 & 0.02 & 0.04 & 0.02 \\
\hline $\mathrm{Cm}-244$ & Floodplain & LWOC & Floodplain & 12 & 4.1 & -0.01 & 0.66 & 1.27 \\
\hline $\mathrm{Cm}-244$ & WOC Weir & MWOC & Weir & 5 & 4.8 & 0.15 & 2.55 & 1.95 \\
\hline $\mathrm{Cm}-244$ & Floodplain & MWOC & Floodplain & 3 & 0.43 & 0.07 & 0.3 & 0.2 \\
\hline $\mathrm{Cm}-244$ & MB Weir & LMBC & Weir & 3 & 2.2 & 0.54 & 1.21 & 0.88 \\
\hline $\mathrm{Cm}-244$ & Floodplain & MMBC & Floodplain & 2 & 0.96 & 0.19 & 0.58 & 0.54 \\
\hline $\mathrm{Cm}-244$ & Seep C & MMBC & Seep & 5 & 13.21 & 0.21 & 6.73 & 5.66 \\
\hline $\mathrm{Cm}-244$ & MB2 Weir & UMBC & Weir & 2 & 0.24 & 0.02 & 0.13 & 0.15 \\
\hline $\mathrm{Cm}-244$ & Floodplain (IHP) & IHP & Floodplain & 20 & 30 & -2.7 & 2.95 & 9.31 \\
\hline $\mathrm{Cm}-244$ & WAG4 T2A & IHP & Seep & 3 & 9.8 & 2.4 & 5.17 & 4.04 \\
\hline $\mathrm{Pu}-238$ & West Seep & LWOC & Seep & 2 & 1.4 & 0.07 & 0.73 & 0.94 \\
\hline Pu-238 & Floodplain & LWOC & Floodplain & 17 & 1.4 & -0.04 & 0.28 & 0.41 \\
\hline Pu-238 & WOC Weir & MWOC & Weir & 5 & 0.9 & 0.05 & 0.48 & 0.36 \\
\hline $\mathbf{P u}-238$ & Floodplain & MWOC & Floodplain & 2 & 1.6 & 0.13 & 0.87 & 1.04 \\
\hline $\mathbf{P u}-238$ & MB Weir & LMBC & Weir & 3 & 4.2 & 0.93 & 2.24 & 1.73 \\
\hline Pu-238 & Floodplain & MMBC & Floodplain & 2 & 0.47 & 0.14 & 0.31 & 0.23 \\
\hline
\end{tabular}


Table B.2 (continued)

\begin{tabular}{|c|c|c|c|c|c|c|c|c|}
\hline Analysis & $\begin{array}{c}\text { Location }^{a} \\
\text { (multiple } F \text { test } \\
\text { results) }\end{array}$ & $\begin{array}{c}\text { Area }^{a} \\
\text { (multiple F } \\
\text { test results) }\end{array}$ & $\begin{array}{c}\text { Type } \\
\text { (multiple } F \text { test } \\
\text { results) }\end{array}$ & $\begin{array}{l}\text { Number of } \\
\text { observations }\end{array}$ & $\begin{array}{c}\text { Maximum } \\
(\mathrm{pCi} / \mathrm{g})\end{array}$ & $\begin{array}{c}\text { Minimum } \\
(\mathrm{pCi} / \mathrm{g})\end{array}$ & $\begin{array}{l}\text { Mean } \\
(\mathrm{pCi} / \mathrm{g})\end{array}$ & $\underset{(p C i / g)}{S D}$ \\
\hline Pu-238 & Seep C & MMBC & Seep & 5 & 1.61 & 0.02 & 0.83 & 0.67 \\
\hline Pu-238 & MB2 Weir & UMBC & Weir & 2 & 0.02 & 0.02 & 0.02 & 0 \\
\hline Pu-238 & Floodplain (IHP) & IHP & Floodplain & 20 & 9.3 & 0.18 & 2.85 & 2.66 \\
\hline Pu-238 & WAG4 T2A & IHP & Seep & 3 & 0.74 & 0.23 & 0.42 & 0.28 \\
\hline $\mathrm{Pu}-239 / 240$ & West Seep & LWOC & Seep (B) & 2 & 71 & 3.5 & 37.25 & 47.73 \\
\hline $\mathrm{Pu}-239 / 240$ & Floodplain & LWOC & Floodplain (A)) & 20 & 32.9 & 0.01 & 5.51 & 9.55 \\
\hline $\mathrm{Pu}-239 / 240$ & WOC Weir & MWOC & Weir (B) & 5 & 5.6 & 0.21 & 3.18 & 2.18 \\
\hline $\mathrm{Pu}-239 / 240$ & Floodplain & MWOC & Floodplain (A) & 2 & 12.7 & 3.12 & 7.91 & 6.77 \\
\hline $\mathrm{Pu}-239 / 240$ & MB Weir & LMBC & Weir (B) & 3 & 0.11 & 0.03 & 0.06 & 0.05 \\
\hline $\mathrm{Pu}-239 / 240$. & Floodplain & MMBC & Floodplain (A) & 2 & 0.47 & 0.14 & 0.31 & 0.23 \\
\hline Pu-239/240 & Seep C & MMBC & Seep (B) & 5 & 0.47 & 0.03 & 0.21 & 0.17 \\
\hline Pu-239/240 & MB2 Weir & UMBC & Weir (B) & 2 & 0.03 & 0 & 0.02 & 0.02 \\
\hline $\mathrm{Pu}-239 / 240$ & Floodplain (IHP) & IHP & Floodplain (A) & 20 & 163 & 6.7 & 59.3 & 50.41 \\
\hline Pu-239/240 & WAG4 T2A & IHP & Seep (B) & 3 & 16 & 3 & 8.18 & 6.89 \\
\hline Tc-99 & West Seep (A) & LWOC (A) & Seep (A) & 2 & 200 & 92 & 146 & 76.37 \\
\hline Tc-99 & Floodplain (B) & LWOC (A) & Floodplain (B) & 19 & 1100 & -4.5 & 109.25 & 315.72 \\
\hline Tc-99 & WOC Weir (B) & MWOC (B) & Weir (B) & 5 & 1.7 & 0.32 & 0.98 & 0.6 \\
\hline Tc-99 & Floodplain (B) & MWOC (B) & Floodplain (B) & 2 & 3.94 & 0.56 & 2.25 & 2.39 \\
\hline Tc-99 & MB Weir (B) & LMBC (B) & Weir (B) & 3 & 0.38 & 0.16 & 0.25 & 0.12 \\
\hline Tc-99 & Floodplain (B) & MMBC (B) & Floodplain (B) & 2 & 0.04 & $\mathbf{0}$ & 0.02 & 0.03 \\
\hline Tc-99 & Seep C (B) & MMBC (B) & Seep (A) & 5 & 9.9 & -0.07 & 2.52 & 4.23 \\
\hline Tc-99 & MB2 Weir (B) & UMBC (B) & Weir (B) & 2 & 0.13 & 0.04 & 0.09 & 0.06 \\
\hline Tc-99 & Floodplain (IHP) (B) & IHP (B) & Floodplain (B) & 21 & 8.41 & 0.37 & 2.96 & 2.28 \\
\hline Te-99 & WAG4 T2A (B) & IHP (B) & Seep (A) & 3 & 2.8 & 1.3 & 2.23 & 0.81 \\
\hline Th-228 & West Seep & LWOC & Seep (AB) & 2 & 6.5 & 5.2 & 5.85 & 0.92 \\
\hline Th-228 & Floodplain & LWOC & Floodplain (A) & 20 & 14.9 & -0.06 & 4.28 & 4.37 \\
\hline Th-228 & WOC Weir & MWOC & Weir (B) & 5 & 1.5 & 0.38 & 1.16 & 0.44 \\
\hline Th-228 & Floodplain & MWOC & Floodplain (A) & 2 & 3.5 & 2.04 & 2.77 & 1.03 \\
\hline
\end{tabular}


Table B.2 (continued)

\begin{tabular}{|c|c|c|c|c|c|c|c|c|}
\hline Analysis & $\begin{array}{c}\text { Location }^{a} \\
\text { (multiple } F \text { test }^{\text {results) }}\end{array}$ & $\begin{array}{c}\text { Area }^{a} \\
\text { (multiple F } \\
\text { test results) }\end{array}$ & $\begin{array}{c}\text { Type } \\
\text { (multiple } F \text { test } \\
\text { results) }\end{array}$ & $\begin{array}{l}\text { Number of } \\
\text { observations }\end{array}$ & $\begin{array}{c}\text { Maximum } \\
(\mathrm{pCi} / \mathrm{g})\end{array}$ & $\underset{(p C i / g)}{\text { Minimum }}$ & $\begin{array}{l}\text { Mean } \\
(p C i / g)\end{array}$ & $\underset{(p C i / g)}{S D}$ \\
\hline Th-228 & MB Weir & LMBC & Weir (B) & 3 & 1.6 & 0.89 & 1.3 & 0.37 \\
\hline Th-228 & Floodplain & MMBC & Floodplain (A) & 2 & 3.2 & 1.14 & 2.17 & 1.46 \\
\hline Th-228 & Seep C & MMBC & Seep (AB) & 5 & 2.21 & 1.77 & 1.95 & 0.19 \\
\hline Th-228 & MB2 Weir & UMBC & Weir (B) & 2 & 1.4 & 0.41 & 0.91 & 0.7 \\
\hline Th-228 & Floodplain (IHP) & IHP & Floodplain (A) & 20 & 17 & 0.5 & 6.45 & 5.85 \\
\hline Th-228 & WAG4 T2A & IHP & Seep (AB) & 3 & 1.9 & 0.69 & 1.26 & 0.61 \\
\hline Th-230 & West Seep (B) & LWOC (B) & Seep (A) & 2 & 1.1 & 0.95 & 1.03 & 0.11 \\
\hline Th-230 & Floodplain (B) & LWOC (B) & Floodplain (B) & 20 & 9.2 & 0.2 & 2.25 & 2.51 \\
\hline Th-230 & WOC Weir (B) & MWOC (B) & Weir (B) & 5 & 1.1 & 0.5 & 0.91 & 0.25 \\
\hline Th-230 & Floodplain (B) & MWOC (B) & Floodplain (B) & 2 & 7.6 & 3.23 & 5.42 & 3.09 \\
\hline Th-230 & MB Weir (B) & LMBC (B) & Weir (B) & 3 & 1.1 & 0.6 & 0.81 & 0.26 \\
\hline Th-230 & Floodplain (B) & MMBC (B) & Floodplain (B) & 2 & 10.7 & 2.38 & 6.54 & 5.88 \\
\hline Th-230 & Seep C (B) & MMBC (B) & Seep (A) & 5 & 2.08 & 1.07 & 1.47 & 0.4 \\
\hline Th-230 & MB2 Weir (B) & UMBC (B) & Weir (B) & 2 & 1.3 & 0.47 & 0.89 & 0.59 \\
\hline Th-230 & Floodplain (IHP) (A) & $\operatorname{IHP}(A)$ & Floodplain (B) & 20 & 33 & 7.3 & 20.61 & 9.16 \\
\hline Th-230 & WAG4 T2A (B) & $\operatorname{IHP}(A)$ & Seep (A) & 3 & 0.96 & 0.83 & 0.88 & 0.07 \\
\hline Th-232 & West Seep & LWOC & Seep (B) & 2 & 1.4 & 1.1 & 1.25 & 0.21 \\
\hline Th-232 & Floodplain & LWOC & Floodplain (A) & 20 & 3.6 & 0.03 & 0.92 & 0.9 \\
\hline Th-232 & WOC Weir & MWOC & Weir (B) & 5 & 1.3 & 0.54 & 0.98 & 0.28 \\
\hline Th-232 & Floodplain & MWOC & Floodplain (A) & 2 & 2 & 1.68 & 1.84 & 0.23 \\
\hline Th-232 & MB Weir & LMBC & Weir (B) & 3 & 1.6 & 0.96 & 1.29 & 0.32 \\
\hline Th-232 & Floodplain & MMBC & Floodplain (A) & 2 & 4.1 & 1.55 & 2.83 & 1.8 \\
\hline Th-232 & Seep C & MMBC & Seep (B) & 5 & 1.41 & 1.31 & 1.35 & 0.04 \\
\hline Th-232 & MB2 Weir & UMBC & Weir (B) & 2 & 1.4 & 0.43 & 0.92 & 0.69 \\
\hline Th-232 & Floodplain (IHP) & IHP & Floodplain (A) & 20 & 10.5 & 0.8 & 5.37 & 3.52 \\
\hline Th-232 & WAG4 T2A & IHP & Seep (B) & 3 & 1.6 & 0.74 & 1.15 & 0.43 \\
\hline Sr-89/90 & West Seep (B) & LWOC (B) & Seep (A) & 4 & 12 & 9.1 & 11.03 & 1.37 \\
\hline Sr-89/90 & Floodplain (B) & LWOC (B) & Floodplain (B) & 20 & 33 & -0.5 & 7.98 & 10.72 \\
\hline
\end{tabular}


Table B.2 (continued)

\begin{tabular}{|c|c|c|c|c|c|c|c|c|}
\hline Analysis & $\begin{array}{c}\text { Location }^{a} \\
\text { (multiple } F \text { test } \\
\text { results) }\end{array}$ & $\begin{array}{c}\text { Area }^{a} \\
\text { (multiple F } \\
\text { test results) }\end{array}$ & $\begin{array}{c}\text { Type } \\
\text { (multiple } F \text { test } \\
\text { results) }\end{array}$ & $\begin{array}{l}\text { Number of } \\
\text { observations }\end{array}$ & $\begin{array}{l}\text { Maximum } \\
(\text { (pCi/g) }\end{array}$ & $\begin{array}{l}\text { Minimum } \\
(\mathrm{pCi} / \mathrm{g})\end{array}$ & $\begin{array}{l}\text { Mean } \\
(\mathrm{pCi} / \mathrm{g})\end{array}$ & $\underset{(\mathrm{pCi} / g)}{S D}$ \\
\hline Sr-89/90 & WOC Weir (B) & MWOC (B) & Weir (B) & 10 & 33 & 1.9 & 14.09 & 10.22 \\
\hline Sr-89/90 & Floodplain (B) & MWOC (B) & Floodplain (B) & 2 & 12.55 & 8.73 & 10.64 & 2.7 \\
\hline $\operatorname{Sr}-89 / 90$ & MB Weir (B) & LMBC (B) & Weir (B) & 6 & 61 & 33 & 45.33 & 10.23 \\
\hline Sr-89/90 & Floodplain (B) & MMBC (A) & Floodplain (B) & 2 & 10.78 & 4.47 & 7.63 & 4.46 \\
\hline Sr-89/90 & Seep C (A) & MMBC (A) & $\operatorname{Seep~(A)}$ & 5 & 30230 & 2632 & 18174.4 & 10534.25 \\
\hline $\mathrm{Sr}-89 / 90$ & MB2 Weir (B) & UMBC (B) & Weir (B) & 4 & 0.19 & -0.18 & 0.02 & 0.16 \\
\hline Sr-89/90 & Floodplain (IHP) (B) & IHP (B) & Floodplain (B) & 20 & 538 & 73.7 & 174.29 & 134.49 \\
\hline Sr-89/90 & WAG4 T2A (B) & IHP (B) & $\operatorname{Seep~(A)~}$ & 6 & 190 & 43 & 94.67 & 70.26 \\
\hline $\mathrm{U}-233 / 234$ & West Seep (A) & LWOC (AB) & $\operatorname{Seep}(A)$ & 2 & 58 & 53 & 55.5 & 3.54 \\
\hline U-233/234 & Floodplain (B) & LWOC (AB) & Floodplain (A) & 19 & 8.5 & 0.05 & 2.29 & 2.52 \\
\hline $\mathrm{U}-233 / 234$ & WOC Weir (B) & MWOC (B) & Weir (B) & 5 & 5.5 & 0.59 & 3.2 & 1.82 \\
\hline $\mathrm{U}-233 / 234$ & Floodplain (B) & MWOC (B) & Floodplain (A) & 2 & 1.4 & 0.84 & 1.12 & 0.4 \\
\hline U-233/234 & MB Weir (B) & LMBC (B) & Weir (B) & 3 & 1.1 & 0.71 & 0.89 & 0.2 \\
\hline $\mathrm{U}-233 / 234$ & Floodplain (B) & MMBC (B) & Floodplain (A) & 2 & 3.3 & 0.45 & 1.88 & 2.02 \\
\hline U-233/234 & Seep C (B) & MMBC (B) & Seep (A) & 5 & 1.62 & 0.87 & 1.23 & 0.34 \\
\hline U-233/234 & MB2 Weir (B) & UMBC (B) & Weir (B) & 2 & 1.1 & 0.27 & 0.69 & 0.59 \\
\hline U-233/234 & Floodplain (IHP) (B) & IHP (A) & Foodplain (A) & 10 & 65 & 6.6 & 26.97 & 20.77 \\
\hline$U-233 / 234$ & WAG4 T2A (B) & IHP (A) & Seep (A) & 3 & 7.3 & 2.8 & 4.43 & 2.49 \\
\hline U-235 & West Seep & LWOC & Seep (B) & 2 & 0.65 & 0.46 & 0.56 & 0.13 \\
\hline $\mathrm{U}-235$ & Floodplain & LWOC & Floodplain (A) & 19 & 1.7 & $\mathbf{0}$ & 0.37 & 0.55 \\
\hline U-235 & WOC Weir & MWOC & Weir (B) & 5 & 0.11 & 0.03 & 0.05 & 0.03 \\
\hline $\mathrm{U}-235$ & Floodplain & MWOC & Floodplain (A) & 2 & 0.46 & 0.1 & 0.28 & 0.25 \\
\hline $\mathrm{U}-235$ & MB Weir & LMBC & Weir (B) & 3 & 0.14 & 0.07 & 0.1 & 0.04 \\
\hline $\mathrm{U}-235$ & Floodplain & MMBC & Floodplain (A) & 2 & 1.2 & 0.22 & 0.71 & 0.69 \\
\hline $\mathrm{U}-235$ & Seep C & MMBC & Seep (B) & 5 & 0.18 & 0.07 & 0.11 & 0.05 \\
\hline $\mathrm{U}-235$ & MB2 Weir & UMBC & Weir (B) & 2 & 0.11 & 0 & 0.06 & 0.08 \\
\hline $\mathrm{U}-235$ & Floodplain (IHP) & IHP & Floodplain (A) & 10 & 13 & -1 & 5.45 & 4.69 \\
\hline U-235 & WAG4 T2A & IHP & Seep (B) & 3 & 0.2 & 0.12 & 0.17 & 0.04 \\
\hline
\end{tabular}


Table B.2 (continued)

\begin{tabular}{|c|c|c|c|c|c|c|c|c|}
\hline Analysis & $\begin{array}{l}\text { Location }^{a} \\
\text { (multiple } F \text { test } \\
\text { results) }\end{array}$ & $\begin{array}{c}\text { Area }^{a} \\
\text { (multiple F } \\
\text { test results) }\end{array}$ & $\begin{array}{c}\text { Type } \\
\text { (multiple } F \text { test } \\
\text { results) }\end{array}$ & $\begin{array}{l}\text { Number of } \\
\text { observations }\end{array}$ & $\begin{array}{c}\text { Maximum } \\
(\mathrm{pCi} / \mathrm{g})\end{array}$ & $\begin{array}{c}\text { Minimum } \\
(\mathrm{pCi} / \mathrm{g})\end{array}$ & $\begin{array}{l}\text { Mean } \\
(\mathrm{pCi} / \mathrm{g})\end{array}$ & $\underset{(p C i / g)}{S D}$ \\
\hline $\mathrm{U}-238$ & West Seep (AB) & LWOC (AB) & Seep (B) & 2 & 3.4 & 3.3 & 3.35 & 0.07 \\
\hline U-238 & Floodplain (B) & LWOC (AB) & Floodplain (A) & 19 & 3.2 & 0 & 0.81 & 0.98 \\
\hline U-238 & WOC Weir (B) & MWOC (B) & Weir (B) & 5 & 1.8 & 0.49 & 1.3 & 0.5 \\
\hline U-238 & Floodplain (B) & MWOC (B) & Floodplain (A) & 2 & 4.7 & 1.04 & 2.87 & 2.59 \\
\hline U-238 & MB Weir (B) & LMBC (B) & Weir (B) & 3 & 1.1 & 0.83 & 0.94 & 0.14 \\
\hline U-238 & Floodplain (B) & MMBC (B) & Floodplain (A) & 2 & 3.5 & 0.65 & 2.08 & 2.02 \\
\hline U-238 & Seep C (B) & MMBC (B) & Seep (B) & 5 & 1.62 & 1.03 & 1.3 & 0.27 \\
\hline U-238 & MB2 Weir (B) & UMBC (B) & Weir (B) & 2 & 0.87 & 0.32 & 0.6 & 0.39 \\
\hline U-238 & Floodplain (IHP) (A) & $\operatorname{IHP}(A)$ & Floodplain (A) & 10 & 28 & 3.1 & 11.7 & 7.47 \\
\hline $\mathrm{U}-238$ & WAG4 TAA (B) & $\operatorname{IHP}(\mathbf{A})$ & Seep (B) & 3 & 4.9 & 1.7 & 2.87 & 1.77 \\
\hline
\end{tabular}

IHP = Intermediate Holding Pond; LMBC = Lower Melton Branch Creek; LWOC = Lower White Oak Creek; MB = Melton Branch; MMBC = Middle Melton Branch Creek; MWOC = Middle White Oak Creek; UMBC = Upper Melton Branch Creek; WAG = waste area grouping; WOC $=$ White Oak Creek.

'Letters in parentheses (e.g., A, B, C) indicate relative significance of means. Means for entries with the same letter are not significantly different $(p>0.05)$. Multiple comparisons tests not run for all classes (e.g., location, area, type) of a given analysis; comparisons valid only within a given analysis. 
Table B.3. Summary of inorganics for Waste Area Grouping 2 noodplain soil and sediment

\begin{tabular}{|c|c|c|c|c|c|c|c|c|}
\hline Analysis & $\begin{array}{l}\text { Location }^{a} \\
\text { (multiple } F \text { test } \\
\text { results) }\end{array}$ & $\begin{array}{c}\text { Area }^{a} \\
\text { (multiple } F \\
\text { test results) }\end{array}$ & $\begin{array}{c}\text { Type } \\
\text { (multiple } F \text { test } \\
\text { results) }\end{array}$ & $\begin{array}{l}\text { Number of } \\
\text { observations }\end{array}$ & $\begin{array}{c}\text { Maximum } \\
(\mathrm{mg} / \mathrm{kg})\end{array}$ & $\begin{array}{l}\text { Minimum } \\
(\mathrm{mg} / \mathrm{kg})\end{array}$ & $\begin{array}{c}\text { Mean } \\
(\mathrm{mg} / \mathrm{kg})\end{array}$ & $\begin{array}{c}\text { SD } \\
(\mathrm{mg} / \mathrm{kg})\end{array}$ \\
\hline Aluminum & West Seep & LWOC & Seep & 2 & 21200 & 14800 & 18000 & 4525.5 \\
\hline Aluminum & Floodplain & LWOC & Floodplain & 8 & 13800 & 24 & 6101.4 & 6539.1 \\
\hline Aluminum & East Seep & LWOC & Seep & 2 & 17700 & 15900 & 16800 & 1272.8 \\
\hline Aluminum & WOC Weir & MWOC & Weir & 5 & 8850 & 6720 & 7672 & 896.64 \\
\hline Alumimum & Floodplain & MWOC & Floodplain & 2 & 11900 & 9250 & 10575 & 1873.8 \\
\hline Aluminum & MB Weir & LMBC & Weir & 3 & 18400 & 15500 & 17267 & 1550.3 \\
\hline Aluminum & Floodplain & MMBC & Floodplain & 2 & 13200 & 12400 & 12800 & 565.69 \\
\hline Aluminum & Seep C & MMBC & Seep & 4 & 27600 & 22200 & 24050 & 2447.5 \\
\hline Aluminum & MB2 Weir & UMBC & Weir & 2 & 15800 & 15200 & 15500 & 424.26 \\
\hline Aluminum & Floodplain (IHP) & IHP & Floodplain & 10 & 28500 & 17700 & 21080 & 3068.8 \\
\hline Aluminum & 7500 Weir & IHP & Weir & 3 & 10100 & 5890 & 7740 & 2150.8 \\
\hline Aluminum & WAG4 T2A & IHP & Seep & 2 & 9130 & 6180 & 7655 & 2086 \\
\hline Antimony & West Seep (C) & LWOC (B) & Seep (B) & 2 & 0.84 & 0.83 & 0.84 & 0.01 \\
\hline Antimony & Floodplain (B) & LWOC (B) & Floodplain (A) & 8 & 12.4 & 2 & 6.91 & 5.26 \\
\hline Antimony & East Seep (C) & LWOC (B) & Seep (B) & 2 & 1.3 & 1.1 & 1.2 & 0.14 \\
\hline Antimony & wOC Weir (C) & MWOC (C) & Weir (C) & 5 & 0.6 & 0.44 & 0.5 & 0.07 \\
\hline Antimony & Floodplain (B) & MWOC (C) & Floodplain (A) & 2 & 13.2 & 12.1 & 12.65 & 0.78 \\
\hline Antimony & MB Weir (C) & LMBC (D) & Weir (C) & 3 & 1.1 & 0.81 & 0.96 & 0.15 \\
\hline Antimony & Floodplain (B) & MMBC (A) & Floodplain (A) & 2 & 11.4 & 10.9 & 11.15 & 0.35 \\
\hline Antimony & Seep C (B) & MMBC (A) & Seep (B) & 4 & 12.1 & 9 & 10 & 1.42 \\
\hline Antimony & MB2 Weir (C) & UMBC (D) & Weir (C) & 2 & 0.96 & 0.76 & 0.86 & 0.14 \\
\hline Antimony & Floodplain (IHP) (A) & IHP (A) & Floodplain (A) & 10 & 17.3 & 12.7 & 14.18 & 1.29 \\
\hline Antimony & 7500 Weir (C) & IHP (A) & Weir (C) & 3 & 0.95 & 0.81 & 0.89 & 0.07 \\
\hline Antimony & WAG4 T2A (C) & IHP (A) & Seep (B) & 2 & 0.65 & 0.37 & 0.51 & 0.2 \\
\hline Arsenic & West Seep & LWOC & Seep & 2 & 6.8 & 1.6 & 4.2 & 3.68 \\
\hline Arsenic & Floodplain & LWOC & Floodplain & 8 & 3 & 1.5 & 2.71 & 0.53 \\
\hline Arsenic & East Seep & LWOC & Seep & 2 & 4.8 & 3.3 & 4.05 & 1.06 \\
\hline Arsenic & WOC Weir & MWOC & Weir & 5 & 7.3 & 3.8 & 4.98 & 1.36 \\
\hline Arsenic & Floodplain & MWOC & Floodplain & 2 & 2.7 & 1.7 & 2.2 & 0.71 \\
\hline Arsenic & MB Weir & LMBC & Weir & 3 & 6.4 & 1.2 & 4.07 & 2.64 \\
\hline
\end{tabular}


Table B.3 (continued)

\begin{tabular}{|c|c|c|c|c|c|c|c|c|}
\hline Analysis & $\begin{array}{l}\text { Location }^{a} \\
\text { (multiple } F \text { test } \\
\text { results) }\end{array}$ & $\begin{array}{c}\text { Area }^{a} \\
\text { (multiple } F \\
\text { test results) }\end{array}$ & $\begin{array}{c}\text { Type } \\
\text { (multiple } F \text { test } \\
\text { results) }\end{array}$ & $\begin{array}{l}\text { Number of } \\
\text { observations }\end{array}$ & $\begin{array}{c}\text { Maximum } \\
(\mathrm{mg} / \mathrm{kg})\end{array}$ & $\begin{array}{l}\text { Minimum } \\
\text { (mg/kg) }\end{array}$ & $\begin{array}{c}\text { Mean } \\
(\mathrm{mg} / \mathrm{kg})\end{array}$ & $\begin{array}{c}\mathrm{SD} \\
(\mathrm{mg} / \mathrm{kg})\end{array}$ \\
\hline Arsenic & Floodplain & MMBC & Floodplain & 2 & 2.2 & 2.2 & 2.2 & 0 \\
\hline Arsenic & Seep C & MMBC & Seep & 4 & 11.2 & 5.4 & 8.98 & 2.5 \\
\hline Arsenic & MB2 Weir & UMBC & Weir & 2 & 7.3 & 5.7 & 6.5 & 1.13 \\
\hline Arsenic & Floodplain (IHP) & IHP & Floodplain & 10 & 6.8 & 3.8 & 5.64 & 0.99 \\
\hline Arsenic & 7500 Weir & IHP & Weir & 3 & 6.7 & 2.4 & 4.93 & 2.25 \\
\hline Arsenic & WAG4 T2A & IHP & Seep & 2 & 7.4 & 3.4 & 5.4 & 2.83 \\
\hline Barium & West Seep & LWOC & Seep & 2 & 263 & 148 & 205.5 & 81.32 \\
\hline Barium & Floodplain & LWOC & Floodplain & 8 & 139 & 25 & 74 & 53.42 \\
\hline Barium & East Seep & LWOC & Seep & 2 & 266 & 181 & 223.5 & 60.1 \\
\hline Barium & WOC Weir & MWOC & Weir & 5 & 138 & 116 & 125.2 & 8.79 \\
\hline Barium & Floodplain & MWOC & Floodplain & 2 & 113 & 85.3 & 99.15 & 19.59 \\
\hline Barium & MB Weir & LMBC & Weir & 3 & 219 & 154 & 188.67 & 32.72 \\
\hline Barium & Floodplain & MMBC & Floodplain & 2 & 119 & 111 & 115 & 5.66 \\
\hline Barium & Seep C & MMBC & Seep & 4 & 632 & 117 & 376.25 & 211.78 \\
\hline Barium & MB2 Weir & UMBC & Weir & 2 & 961 & 264 & 612.5 & 492.85 \\
\hline Barium & Floodplain (IHP) & IHP & Floodplain & 10 & 268 & 112 & 176.2 & 57.28 \\
\hline Barium & 7500 Weir & IHP & Weir & 3 & 100 & 61.7 & 80.3 & 19.17 \\
\hline Barium & WAG4 T2A & IHP & Seep & 2 & 166 & 80.6 & 123.3 & 60.39 \\
\hline Beryllium & West Seep & LWOC & Seep & 2 & 1.5 & 0.95 & 1.23 & 0.39 \\
\hline Beryllium & Floodplain & LWOC & Floodplain & 8 & 1 & 0.73 & 0.94 & 0.1 \\
\hline Beryllium & East Seep & LWOC & Seep & 2 & 1.1 & 1 & 1.05 & 0.07 \\
\hline Beryllium & WOC Weir & MWOC & Weir & 5 & 0.99 & 0.77 & 0.91 & 0.08 \\
\hline Beryllium & Floodplain & MWOC & Floodplain & 2 & 0.75 & 0.54 & 0.65 & 0.15 \\
\hline Beryllium & MB Weir & LMBC & Weir & 3 & 1.3 & 1.1 & 1.23 & 0.12 \\
\hline Beryllium & Floodplain & MMBC & Floodplain & 2 & 0.8 & 0.74 & 0.77 & 0.04 \\
\hline Beryllium & Seep C & MMBC & Seep & 4 & 1.8 & 1.1 & 1.33 & 0.32 \\
\hline Beryllium & MB2 Weir & UMBC & Weir & 2 & 1.5 & 1.4 & 1.45 & 0.07 \\
\hline Beryllium & Floodplain (IHP) & IHP & Floodplain & 10 & 1.7 & 0.86 & 1.22 & 0.29 \\
\hline Beryllium & 7500 Weir & IHP & Weir & 3 & 0.93 & 0.56 & 0.77 & 0.19 \\
\hline
\end{tabular}


Table B.3 (continued)

\begin{tabular}{|c|c|c|c|c|c|c|c|c|}
\hline Analysis & $\begin{array}{l}\text { Location }^{a} \\
\text { (multiple } F \text { test } \\
\text { results) }\end{array}$ & $\begin{array}{c}\text { Area }^{a} \\
\text { (multiple F } \\
\text { test results) }\end{array}$ & $\begin{array}{c}\text { Type } \\
\text { (multiple } F \text { test } \\
\text { results) }\end{array}$ & $\begin{array}{c}\text { Number of } \\
\text { observations }\end{array}$ & $\begin{array}{c}\text { Maximum } \\
(\mathbf{m g} / \mathbf{k g})\end{array}$ & $\begin{array}{c}\text { Minimum } \\
(\mathbf{m g} / \mathbf{k g})\end{array}$ & $\begin{array}{c}\text { Mean } \\
(\mathrm{mg} / \mathrm{kg})\end{array}$ & $\underset{(\mathrm{mg} / \mathrm{kg})}{\mathrm{SD}}$ \\
\hline Beryllium & WAG4 T2A & IHP & Seep & 2 & 0.94 & 0.88 & 0.91 & 0.04 \\
\hline Boron & West Seep & LWOC & Seep & 2 & 4.5 & 4.4 & 4.45 & 0.07 \\
\hline Boron & Floodplain & LWOC & Floodplain & 8 & 59.1 & 9.4 & 25.81 & 20.6 \\
\hline Boron & East Seep & LWOC & Seep & 2 & 6.1 & 5.1 & 5.6 & 0.71 \\
\hline Boron & WOC Weir & MWOC & Weir & 5 & 4.8 & 3.5 & 3.98 & 0.59 \\
\hline Boron & Floodplain & MWOC & Floodplain & 2 & 10.9 & 10 & 10.45 & 0.64 \\
\hline Boron & MB Weir & LMBC & Weir & 3 & 5.6 & 4.3 & 4.9 & 0.66 \\
\hline Boron & Floodplain & MMBC & Floodplain & 2 & 9.4 & 9 & 9.2 & 0.28 \\
\hline Boron & Seep C & MMBC & Seep & 4 & 8.1 & 2.5 & 4.15 & 2.65 \\
\hline Boron & MB2 Weir & UMBC & Weir & 2 & 4.2 & 4 & 4.1 & 0.14 \\
\hline Boron & Floodplain (IHP) & IHP & Floodplain & 10 & 10.2 & 4.1 & 6.34 & 1.74 \\
\hline Boron & 7500 Weir & IHP & Weir & 3 & 5.1 & 4.3 & 4.77 & 0.42 \\
\hline Boron & WAG4 T2A & IHP & Seep & 2 & 5.2 & 2.9 & 4.05 & 1.63 \\
\hline Cadmium & West Seep & LWOC & Seep & 2 & 0.28 & 0.27 & 0.28 & 0.01 \\
\hline Cadmium & Floodplain & LWOC & Floodplain & 8 & 1 & 0.74 & 0.92 & 0.12 \\
\hline Cadmium & East Seep & LWOC & Seep & 2 & 0.38 & 0.32 & 0.35 & 0.04 \\
\hline Cadmium & WOC Weir & MWOC & Weir & 5 & 1.7 & 0.64 & 1.11 & 0.5 \\
\hline Cadmium & Floodplain & MWOC & Floodplain & 2 & 0.86 & 0.79 & 0.83 & 0.05 \\
\hline Cadmium & MB Weir & LMBC & Weir & 3 & 0.35 & 0.27 & 0.31 & 0.04 \\
\hline Cadmium & Floodplain & MMBC & Floodplain & 2 & 0.74 & 0.71 & 0.73 & 0.02 \\
\hline Cadmium & Seep C & MMBC & Seep & 4 & 1.1 & 1 & 1.08 & 0.05 \\
\hline Cadmium & MB2 Weir & UMBC & Weir & 2 & 0.26 & 0.25 & 0.26 & 0.01 \\
\hline Cadmium & Floodplain (IHP) & IHP & Floodplain & 10 & 1.5 & 1.1 & 1.2 & 0.15 \\
\hline Cadmium & 7500 Weir & IHP & Weir & 3 & 0.9 & 0.45 & 0.69 & 0.23 \\
\hline Cadmium & WAG4 T2A & IHP & Seep & 2 & 1.4 & 0.71 & 1.06 & 0.49 \\
\hline Calcium & West Seep & LWOC & Seep & 2 & 3690 & 3390 & 3540 & 212.13 \\
\hline Calcium & Floodplain & LWOC & Floodplain & 8 & 3870 & 340 & 1593.3 & 1423.6 \\
\hline Calcium & East Seep & LWOC & Seep & 2 & 42500 & 33200 & 37850 & 6576.1 \\
\hline Calcium & WOC Weir & MWOC & Weir & 5 & 66800 & 10100 & 29100 & 26294 \\
\hline
\end{tabular}


Table B.3 (continued)

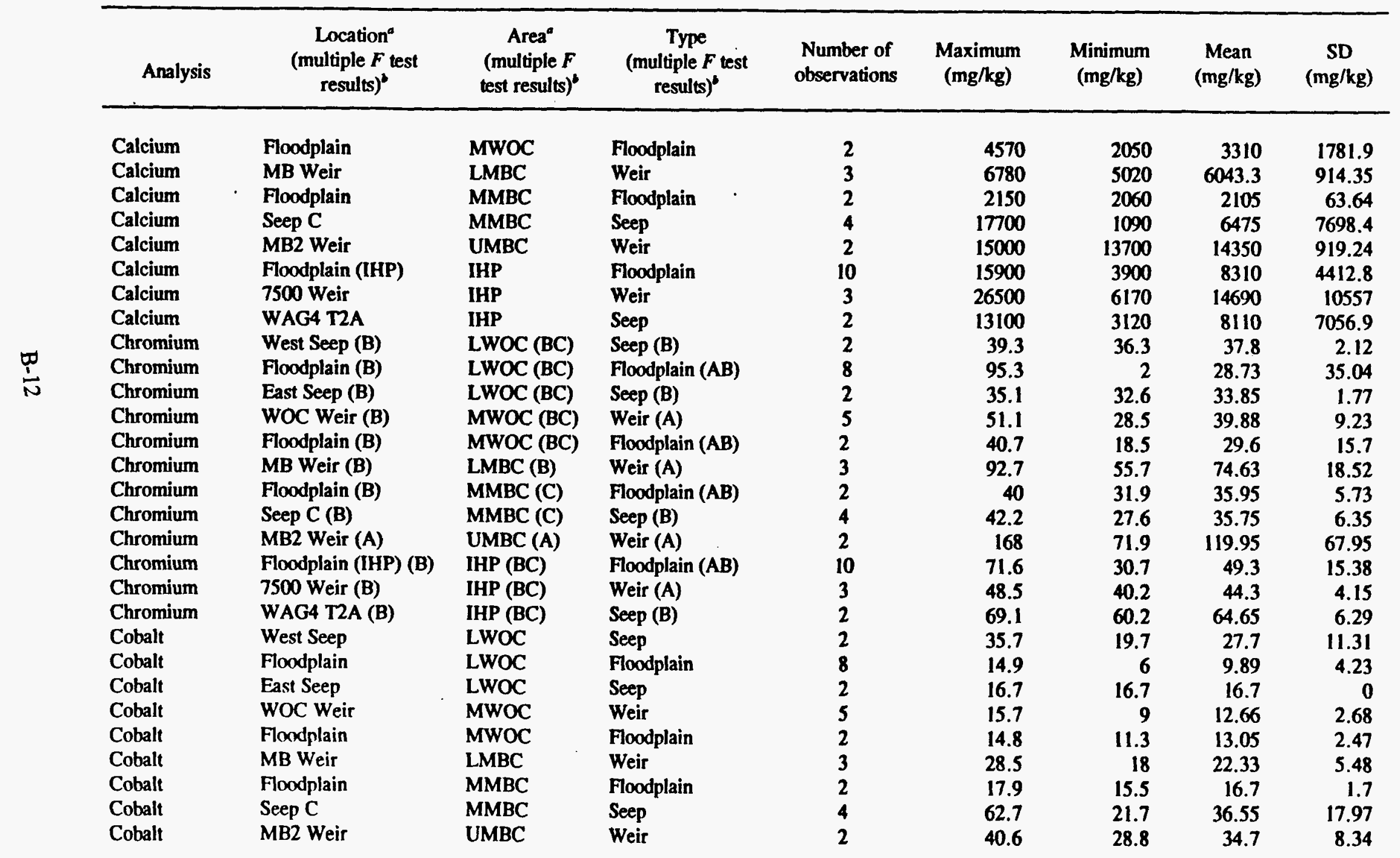


Table B.3 (continued)

\begin{tabular}{|c|c|c|c|c|c|c|c|c|}
\hline Analysis & $\begin{array}{l}\text { Location }^{a} \\
\text { (multiple } F \text { test } \\
\text { results) }\end{array}$ & $\begin{array}{c}\text { Area }^{a} \\
\text { (multiple } F \\
\text { test results) }\end{array}$ & $\begin{array}{c}\text { Type } \\
\text { (multiple } F \text { test } \\
\text { results) }\end{array}$ & $\begin{array}{l}\text { Number of } \\
\text { observations }\end{array}$ & $\begin{array}{l}\text { Maximum } \\
(\mathrm{mg} / \mathrm{kg})\end{array}$ & $\begin{array}{l}\text { Minimum } \\
(\mathrm{mg} / \mathrm{kg})\end{array}$ & $\begin{array}{c}\text { Mean } \\
(\mathrm{mg} / \mathrm{kg})\end{array}$ & $\underset{(\mathrm{mg} / \mathrm{kg})}{\mathrm{SD}}$ \\
\hline Cobalt & Floodplain (IHP) & IHP & Floodplain & 10 & 16 & 11.5 & 12.76 & 1.46 \\
\hline Cobalt & 7500 Weir & IHP & Weir & 3 & 11.8 & 7.2 & 9.8 & 2.36 \\
\hline Cobalt & WAG4 T2A & IHP & Seep & 2 & 16.2 & 6.6 & 11.4 & 6.79 \\
\hline Copper & West Seep & LWOC & Seep & 2 & 21.3 & 13.5 & 17.4 & 5.52 \\
\hline Copper & Floodplain & LWOC & Floodplain & 8 & 35.2 & 4 & 13.41 & 11.86 \\
\hline Copper & East Seep & LWOC & Seep & 2 & 54.4 & 27.5 & 40.95 & 19.02 \\
\hline Copper & WOC Weir & MWOC & Weir & 5 & 163 & 35.7 & 84.92 & 53.28 \\
\hline Copper & Floodplain & MWOC & Floodplain & 2 & 35.3 & 12.3 & 23.8 & 16.26 \\
\hline Copper & MB Weir & LMBC & Weir & 3 & 28.2 & 13.7 & 20.43 & 7.31 \\
\hline Copper & Floodplain & MMBC & Floodplain & 2 & 15.1 & 12.7 & 13.9 & 1.7 \\
\hline Copper & Seep C & MMBC & Seep & 4 & 36.5 & 17.8 & 26.48 & 8.51 \\
\hline Copper & MB2 Weir & UMBC & Weir & 2 & 32.8 & 22.8 & 27.8 & 7.07 \\
\hline Copper & Floodplain (IHP) & IHP & Floodplain & 10 & 45.1 & 18.8 & 27.6 & 8.53 \\
\hline Copper & 7500 Weir & IHP & Weir & 3 & 62.3 & 26.3 & 44.33 & 18 \\
\hline Copper & WAG4 T2A & IHP & Seep & 2 & 64.9 & 15.1 & 40 & 35.21 \\
\hline Iron & West Seep & LWOC & Seep & 2 & 59600 & 34200 & 46900 & 17961 \\
\hline Iron & Floodplain & LWOC & Floodplain & 8 & 25200 & 5 & 11280 & 12132 \\
\hline Iron & East Seep & LWOC & Seep & 2 & 28000 & 22700 & 25350 & 3747.7 \\
\hline Iron & wOC Weir & MWOC & Weir & 5 & 24800 & 16400 & 20460 & 3697 \\
\hline Iron & Floodplain & MWOC & Floodplain & 2 & 21600 & 17200 & 19400 & 3111.3 \\
\hline Iron & MB Weir & LMBC & Weir & 3 & 39600 & 35200 & 37333 & 2203 \\
\hline Iron & Floodplain & MMBC & Floodplain & 2 & 23300 & 20100 & 21700 & 2262.7 \\
\hline Iron & Seep C & MMBC & Seep & 4 & 64300 & 34100 & 45075 & 13240 \\
\hline Iron & MB2 Weir & UMBC & Weir & 2 & 81600 & 51800 & 66700 & 21072 \\
\hline Iron & Flondplain (IHP) & IHP & Floodplain & 10 & 34000 & 23100 & 27810 & 3778.7 \\
\hline Iron & 7500 Weir & IHP & Weir & 3 & 25900 & 17600 & 22533 & 4366.2 \\
\hline Iron & WAG4 T2A & IHP & Seep & 2 & 26500 & 19300 & 22900 & 5091.2 \\
\hline Lead & West Seep & LWOC & Seep & 2 & 17 & 11.1 & 14.05 & 4.17 \\
\hline Lead & Floodplain & LWOC & Floodplain & 8 & 50.4 & 2 & 18.89 & 19.65 \\
\hline
\end{tabular}


Table B.3 (continued)

\begin{tabular}{|c|c|c|c|c|c|c|c|c|}
\hline Analysis & $\begin{array}{c}\text { Location }^{a} \\
\text { (multiple } F_{\text {test }} \\
\text { results) }\end{array}$ & $\begin{array}{c}\text { Area }^{a} \\
\text { (multiple } F \\
\text { test results) }\end{array}$ & $\begin{array}{c}\text { Type } \\
\text { (multiple } F \text { test } \\
\text { results) }\end{array}$ & $\begin{array}{l}\text { Number of } \\
\text { observations }\end{array}$ & $\begin{array}{l}\text { Maximum } \\
(\mathrm{mg} / \mathrm{kg})\end{array}$ & $\begin{array}{l}\text { Minimum } \\
(\mathrm{mg} / \mathrm{kg})\end{array}$ & $\begin{array}{c}\text { Mean } \\
(\mathrm{mg} / \mathrm{kg})\end{array}$ & $\begin{array}{c}\text { SD } \\
(\mathrm{mg} / \mathrm{kg})\end{array}$ \\
\hline Lead & East Seep & LWOC & Seep & 2 & 19.2 & 16.3 & 17.75 & 2.05 \\
\hline Lead & WOC Weir & MWOC & Weir & 5 & 79.7 & 29 & 48.78 & 22.13 \\
\hline Lead & Floodplain & MWOC & Floodplain & 2 & 37.8 & 18.3 & 28.05 & 13.79 \\
\hline Lead & MB Weir & LMBC & Weir & 3 & 20.1 & 4.7 & 13.6 & 7.98 \\
\hline Lead & Floodplain & MMBC & Floodplain & 2 & 17.8 & 17.7 & 17.75 & 0.07 \\
\hline Lead & Seep C & MMBC & Seep & 4 & 18.8 & 11.8 & 16.1 & 3.16 \\
\hline Lead & MB2 Weir & UMBC & Weir & 2 & 15.1 & 12.6 & 13.85 & 1.77 \\
\hline Lead & Floodplain (IHP) & IHP & Floodplain & 10 & 111 & 22.8 & 59.18 & 29.36 \\
\hline Lead & 7500 Weir & IHP & Weir & 3 & 62.5 & 26.4 & 42.83 & 18.27 \\
\hline Lead & WAG4 T2A & IHP & Seep & 2 & 55.4 & 23.3 & 39.35 & 22.7 \\
\hline Lithium & West Seep & LWOC & Seep & 2 & 26.6 & 17.8 & 22.2 & 6.22 \\
\hline Lithium & Floodplain & LWOC & Floodplain & 8 & 30 & 12.9 & 21.98 & 8.64 \\
\hline Lithium & East Seep & LWOC & Seep & 2 & 20 & 19 & 19.5 & 0.71 \\
\hline Lithium & WOC Weir & MWOC & Weir & 5 & 11.6 & 8 & 9.38 & 1.49 \\
\hline Lithium & Floodplain & MWOC & Floodplain & 2 & 13 & 9.4 & 11.2 & 2.55 \\
\hline Lithium & MB Weir & LMBC & Weir & 3 & 27.3 & 23.3 & 24.83 & 2.16 \\
\hline Lithium & Floodplain & MMBC & Floodplain & 2 & 15 & 14.2 & 14.6 & 0.57 \\
\hline Lithium & Seep C & MMBC & Seep & 4 & 25.9 & 20.1 & 23.03 & 2.81 \\
\hline Lithium & MB2 Weir & UMBC & Weir & 2 & 24.9 & 22.1 & 23.5 & 1.98 \\
\hline Lithium & Floodplain (IHP) & IHP & Floodplain & 10 & 41.4 & 18.9 & 26.22 & 7.85 \\
\hline Lithium & 7500 Weir & IHP & Weir & 3 & 11.8 & 8.1 & 9.67 & 1.91 \\
\hline Lithium & WAG4 T2A & IHP & Seep & 2 & 13.3 & 6.2 & 9.75 & 5.02 \\
\hline Magnesium & West Seep & LWOC & Seep & 2 & 5390 & 3240 & 4315 & 1520.3 \\
\hline Magnesium & Floodplain & LWOC & Floodplain & 8 & 2320 & 570 & 1321.3 & 812.48 \\
\hline Magnesium & East Seep & LWOC & Seep & 2 & 8840 & 7500 & 8170 & 947.52 \\
\hline Magnesium & wOC Weir & MWOC & Weir & 5 & 11200 & 2540 & 5124 & 3803.9 \\
\hline Magnesium & Floodplain & MWOC & Floodplain & 2 & 1900 & 1180 & 1540 & 509.12 \\
\hline Magnesium & MB Weir & LMBC & Weir & 3 & 7000 & 4450 & 5720 & 1275 \\
\hline Magnesium & Floodplain & MMBC & Floodplain & 2 & 2480 & 2240 & 2360 & 169.71 \\
\hline
\end{tabular}


Table B.3 (continued)

\begin{tabular}{|c|c|c|c|c|c|c|c|c|}
\hline Analysis & $\begin{array}{l}\text { Location }^{a} \\
\text { (multiple } F \text { test } \\
\text { results) }\end{array}$ & $\begin{array}{c}\text { Area }^{\circ} \\
\text { (multiple } F \\
\text { test results) }\end{array}$ & $\begin{array}{c}\text { Type } \\
\text { (multiple } F \text { test } \\
\text { results) }\end{array}$ & $\begin{array}{l}\text { Number of } \\
\text { observations }\end{array}$ & $\begin{array}{c}\text { Maximum } \\
(\mathrm{mg} / \mathrm{kg})\end{array}$ & $\begin{array}{c}\text { Minimum } \\
\text { (mg/kg) }\end{array}$ & $\begin{array}{c}\text { Mean } \\
(\mathrm{mg} / \mathrm{kg})\end{array}$ & $\begin{array}{c}\mathrm{SD} \\
(\mathrm{mg} / \mathrm{kg})\end{array}$ \\
\hline Magnesium & Seep C & MMBC & Seep & 4 & 5330 & 3930 & 4805 & 616.9 \\
\hline Magnesium & MB2 Weir & UMBC & Weir & 2 & 7020 & 5500 & 6260 & 1074.8 \\
\hline Magnesium & 'Floodplain (IHP) & IHP & Floodplain & 10 & 3840 & 2260 & 2935 . & 432.42 \\
\hline Magnesium & 7500 Weir & IHP & Weir & 3 & 2250 & 1150 & 1806.7 & 580.2 \\
\hline Magnesium & WAG4 T2A & IHP & Seep & 2 & 2440 & 1050 & 1745 & 982.88 \\
\hline Manganese & West Seep & LWOC & Seep & 2 & 2040 & 1420 & 1730 & 438.41 \\
\hline Manganese & Floodplain & LWOC & Floodplain & 8 & 1280 & 2 & 485.63 & 562.62 \\
\hline Manganese & East Seep & LWOC & Seep & 2 & 2240 & 1820 & 2030 & 296.98 \\
\hline Manganese & WOC Weir & MWOC & Weir & 5 & 790 & 516 & 660.4 & 100.95 \\
\hline Manganese & Floodplain & MWOC & Floodplain & 2 & 909 & 823 & 866 & 60.81 \\
\hline Manganese & MB Weir & LMBC & Weir & 3 & 2040 & 866 & 1622 & 655.94 \\
\hline Manganese & Floodplain & MMBC & Floodplain & 2 & 1280 & 1200 & 1240 & 56.57 \\
\hline Manganese & Seep C & MMBC & Seep & 4 & 11600 & 2680 & 7907.5 & 3794.3 \\
\hline Manganese & MB2 Weir & UMBC & Weir & 2 & 8330 & 2860 & 5595 & 3867.9 \\
\hline Manganese & Floodplain (IHP) & IHP & Floodplain & 10 & 4150 & 633 & 1240.1 & 1035.2 \\
\hline Manganese & 7500 Weir & IHP & Weir & 3 & 774 & 618 & 708.67 & 81.03 \\
\hline Manganese & WAG4 T2A & IHP & Seep & 2 & 1320 & 316 & 818 & 709.94 \\
\hline Mercury & West Seep (A) & LWOC (A) & Seep (A) & 2 & 0.19 & 0.16 & 0.18 & 0.02 \\
\hline Mercury & Floodplain (A) & LWOC (A) & Floodplain (A) & 8 & 5.1 & 0.2 & 1.58 & 1.96 \\
\hline Mercury & East Seep (A) & LWOC (A) & $\operatorname{Seep}(A)$ & 2 & 0.18 & 0.17 & 0.18 & 0.01 \\
\hline Mercury & WOC Weir (A) & MWOC (A) & Weir (A) & 5 & 4.8 & 1.2 & 2.6 & 1.83 \\
\hline Mércury & Floodplain (A) & MWOC (A) & Floodplain (A) & 2 & 2.5 & 0.61 & 1.56 & 1.34 \\
\hline Mercury & MB Weir (A) & LMBC (A) & Weir (A) & 3 & 0.16 & 0.1 & 0.13 & 0.03 \\
\hline Mercury & Floodplain (A) & $\operatorname{MMBC}(\mathrm{A})$ & Floodplain (A) & 2 & 2 & 0.12 & 1.06 & 1.33 \\
\hline Mercury & Seep C (A) & $\operatorname{MMBC}(\mathrm{A})$ & $\operatorname{Seep}(A)$ & 4 & 0.14 & 0.13 & 0.14 & 0.01 \\
\hline Mercury & MB2 Weir (A) & $\operatorname{UMBC}(\mathrm{A})$ & Weir (A) & 2 & 0.11 & 0.11 & 0.11 & 0 \\
\hline Mercury & Floodplain (IHP) (A) & $\operatorname{IHP}(A)$ & Floodplain (A) & 10 & 76.4 & 0.28 & 16.59 & 26.37 \\
\hline Mercury & 7500 Weir (A) & $\operatorname{IHP}(A)$ & Weir (A) & 3 & 3.8 & 1.6 & 2.67 & 1.1 \\
\hline Mercury & WAG4 T2A (A) & $\operatorname{IHP}(A)$ & Seep (A) & 2 & 3.4 & 1.1 & 2.25 & 1.63 \\
\hline
\end{tabular}


Table B.3 (continued)

\begin{tabular}{|c|c|c|c|c|c|c|c|c|}
\hline Analysis & $\begin{array}{l}\text { Location }^{a} \\
\text { (multiple } F \text { test } \\
\text { results) }\end{array}$ & $\begin{array}{c}\text { Area }^{a} \\
\text { (multiple F } \\
\text { test results) }\end{array}$ & $\begin{array}{c}\text { Type } \\
\text { (multiple } F \text { test } \\
\text { results) }\end{array}$ & $\begin{array}{l}\text { Number of } \\
\text { observations }\end{array}$ & $\begin{array}{c}\text { Maximum } \\
\text { (mg/kg) }\end{array}$ & $\begin{array}{l}\text { Minimum } \\
(\mathrm{mg} / \mathrm{kg})\end{array}$ & $\begin{array}{c}\text { Mean } \\
\text { (mg/kg) }\end{array}$ & $\begin{array}{c}\text { SD } \\
(\mathrm{mg} / \mathrm{kg})\end{array}$ \\
\hline Molybdenum & West Seep & LWOC & Seep & 2 & 3.1 & 3 & 3.05 & 0.07 \\
\hline Molybdenum & Floodplain & LWOC & Floodplain & 8 & 11 & 3.5 & 7.3 & 3.96 \\
\hline Molybdenum & East Seep & LWOC & Seep & 2 & 4.2 & 3.5 & 3.85 & 0.49 \\
\hline Molybdenum & WOC Weir & MWOC & Weir & 5 & 3.3 & 2.4 & 2.72 & 0.41 \\
\hline Molybdenum & Floodplain & MWOC & Floodplain & 2 & 4 & 3.7 & 3.85 & 0.21 \\
\hline Molybdenum & MB Weir & LMBC & Weir & 3 & 3.9 & 3 & 3.4 & 0.46 \\
\hline Molybdenum & Floodplain & MMBC & Floodplain & 2 & 3.5 & 3.3 & 3.4 & 0.14 \\
\hline Molybdenum & Seep C & MMBC & Seep & 4 & 7.3 & 6.5 & 6.95 & 0.37 \\
\hline Molybdenum & MB2 Weir & UMBC & Weir & 2 & 2.9 & 2.8 & 2.85 & 0.07 \\
\hline Molybdenum & Floodplain (IHP) & IHP & Floodplain & 10 & 5.2 & 3.8 . & 4.26 & 0.39 \\
\hline Molybdenum & 7500 Weir & IHP & Weir & 3 & 3.5 & 3 & 3.3 & 0.26 \\
\hline Molybdenum & WAG4 T2A & IHP & Seep & 2 & 3.6 & 2 & 2.8 & 1.13 \\
\hline Nickel & West Seep (A) & LWOC (A) & Seep (A) & 2 & 39.5 & 24.3 & 31.9 & 10.75 \\
\hline Nickel & Floodplain (A) & LWOC (A) & Floodplain (A) & 8 & 20.6 & 11 & 14.91 & 4.34 \\
\hline Nickel & East Seep (A) & LWOC (A) & Seep (A) & 2 & 26.9 & 22.4 & 24.65 & 3.18 \\
\hline Nickel & WOC Weir (A) & MWOC (A) & Weir (A) & 5 & 26.4 & 16.7 & 20.62 & 4.56 \\
\hline Nickel & Floodplain (A) & MWOC (A) & Floodplain (A) & 2 & 22.4 & 11.8 & 17.1 & 7.5 \\
\hline Nickel & MB Weir (A) & $\operatorname{LMBC}(\mathrm{A})$ & Weir (A) & 3 & 45.6 & 33.6 & 37.8 & 6.76 \\
\hline Nickel & Floodplain (A) & MMBC (A) & Floodplain (A) & 2 & 22.5 & 20.2 & 21.35 & 1.63 \\
\hline Nickel & Seep C (A) & MMBC (A) & Seep $(A)$ & 4 & 46 & 36.8 & 41.48 & 3.87 \\
\hline Nickel & MB2 Weir (A) & UMBC (A) & Weir (A) & 2 & 40.4 & 37.7 & 39.05 & 1.91 \\
\hline Nickel & Floodplain (IHP) (A) & IHP (A) & Floodplain (A) & 10 & 310 & 17.6 & 50.24 & 91.31 \\
\hline Nickel & 7500 Weir (A) & $\operatorname{IHP}(A)$ & Weir (A) & 3 & 18 & 8.3 & 12.4 & 5.02 \\
\hline Nickel & WAG4 T2A (A) & $\operatorname{IHP}(\mathbf{A})$ & Seep (A) & 2 & 114 & 15.4 & 64.7 & 69.72 \\
\hline Osmium & West Seep & LWOC & Seep & 2 & 12.4 & 8.5 & 10.45 & 2.76 \\
\hline Osmium & Floodplain & LWOC & Floodplain & 8 & 37.6 & 6.7 & 19.8 & 13.91 \\
\hline Osmium & East Seep & LWOC & Seep & 2 & 11.8 & 9.9 & 10.85 & 1.34 \\
\hline Osmium & WOC Weir & MWOC & Weir & 5 & 9.3 & 6.8 & 7.72 & 1.12 \\
\hline Osmium & Floodplain & MWOC & Floodplain & 2 & 7.7 & 7.1 & 7.4 & 0.42 \\
\hline
\end{tabular}


Table B.3 (continued)

\begin{tabular}{|c|c|c|c|c|c|c|c|c|}
\hline Analysis & $\begin{array}{l}\text { Location }^{a} \\
\text { (multiple } F \text { test }^{\text {results) }}\end{array}$ & $\begin{array}{c}\text { Area }^{a} \\
\text { (multiple } F \\
\text { test results) }\end{array}$ & $\begin{array}{c}\text { Type } \\
\text { (multiple } F \text { test } \\
\text { results) }\end{array}$ & $\begin{array}{l}\text { Number of } \\
\text { observations }\end{array}$ & $\begin{array}{l}\text { Maximum } \\
\text { (mg/kg) }\end{array}$ & $\begin{array}{l}\text { Minimum } \\
\text { (mg/kg) }\end{array}$ & $\begin{array}{c}\text { Mean } \\
(\mathrm{mg} / \mathrm{kg})\end{array}$ & $\begin{array}{c}\mathrm{SD} \\
(\mathrm{mg} / \mathrm{kg})\end{array}$ \\
\hline Osmium & MB Weir & LMBC & Weir & 3 & 10.9 & 8.3 & 9.47 & 1.32 \\
\hline Osmium & Floodplain & MMBC & Floodplain & 2 & 6.7 & 6.4 & 6.55 & 0.21 \\
\hline Osmium & Seep C & MMBC & Seep & 4 & 12.2 & 6.3 & 7.95 & 2.84 \\
\hline Osmium & MB2 Weir & UMBC & Weir & 2 & 8.5 & 7.8 & 8.15 & 0.49 \\
\hline Osmium & Floodplain (IHP) & IHP & Floodplain & 10 & 9.4 & 6.9 & 7.69 & 0.7 \\
\hline Osmium & 7500 Weir & IHP & Weir & 3 & 9.8 & 8.4 & 9.23 & 0.74 \\
\hline Osmium & WAG4 T2A & IHP & Seep & 2 & 10.1 & 5.7 & 7.9 & 3.11 \\
\hline Potassium & West Seep & LWOC & Seep & 2 & 1930 & 1730 & 1830 & 141.42 \\
\hline Potassium & Floodplain & LWOC & Floodplain & 8 & 1440 & 1000 & 1161.3 & 192.53 \\
\hline Potassium & East Seep & LWOC & Seep & 2 & 2100 & 2010 & 2055 & 63.64 \\
\hline Potassium & WOC Weir & MWOC & Weir & 5 & 720 & 355 & 533.2 & 173.57 \\
\hline Potassium & Floodplain & MWOC & Floodplain & 2 & 1100 & 967 & 1033.5 & 94.05 \\
\hline Potassium & MB Weir & LMBC & Weir & 3 & 2830 & 1910 & 2396.7 & 462.31 \\
\hline Potassium & Floodplain & MMBC & Floodplain & 2 & 1840 & 1680 & 1760 & 113.14 \\
\hline Potassium & Seep C & MMBC & Seep & 4 & 3690 & 2470 & 2940 & 574.69 \\
\hline Potassium & MB2 Weir & UMBC & Weir & 2 & 2020 & 1980 & 2000 & 28.28 \\
\hline Potassium & Floodplain (IHP) & IHP & Floodplain & 10 & 3410 & 2340 & 2650 & 372.11 \\
\hline Potassium & 7500 Weir & IHP & Weir & 3 & 1040 & 604 & 888 & 246.15 \\
\hline Potassium & WAG4 T2A & IHP & Seep & 2 & 799 & 376 & 587.5 & 299.11 \\
\hline Selenium & West Seep & LWOC & Seep & 2 & 0.84 & 0.82 & 0.83 & 0.01 \\
\hline Selenium & Floodplain & LWOC & Floodplain & 8 & 3 & 0.84 & 2.04 & 1.04 \\
\hline Selenium & East Seep & LWOC & Seep & 2 & 1.2 & 0.95 & 1.08 & 0.18 \\
\hline Selenium & WOC Weir & MWOC & Weir & 5 & 0.9 & 0.65 & 0.75 & 0.11 \\
\hline Selenium & Floodplain & MWOC & Floodplain & 2 & 1.6 & 0.86 & 1.23 & 0.52 \\
\hline Selenium & MB Weir & LMBC & Weir & 3 & 1 & 0.81 & 0.9 & 0.1 \\
\hline Selenium & Floodplain & MMBC & Floodplain & 2 & 1.3 & 0.79 & 1.05 & 0.36 \\
\hline Selenium & Seep C & MMBC & Seep & 4 & 0.84 & 0.75 & 0.81 & 0.04 \\
\hline Selenium & MB2 Weir & UMBC & Weir & 2 & 0.78 & 0.75 & 0.77 & 0.02 \\
\hline Selenium & Floodplain (IHP) & IHP & Floodplain & 10 & 0.69 & 0.51 & 0.57 & 0.05 \\
\hline
\end{tabular}


Table B.3 (continued)

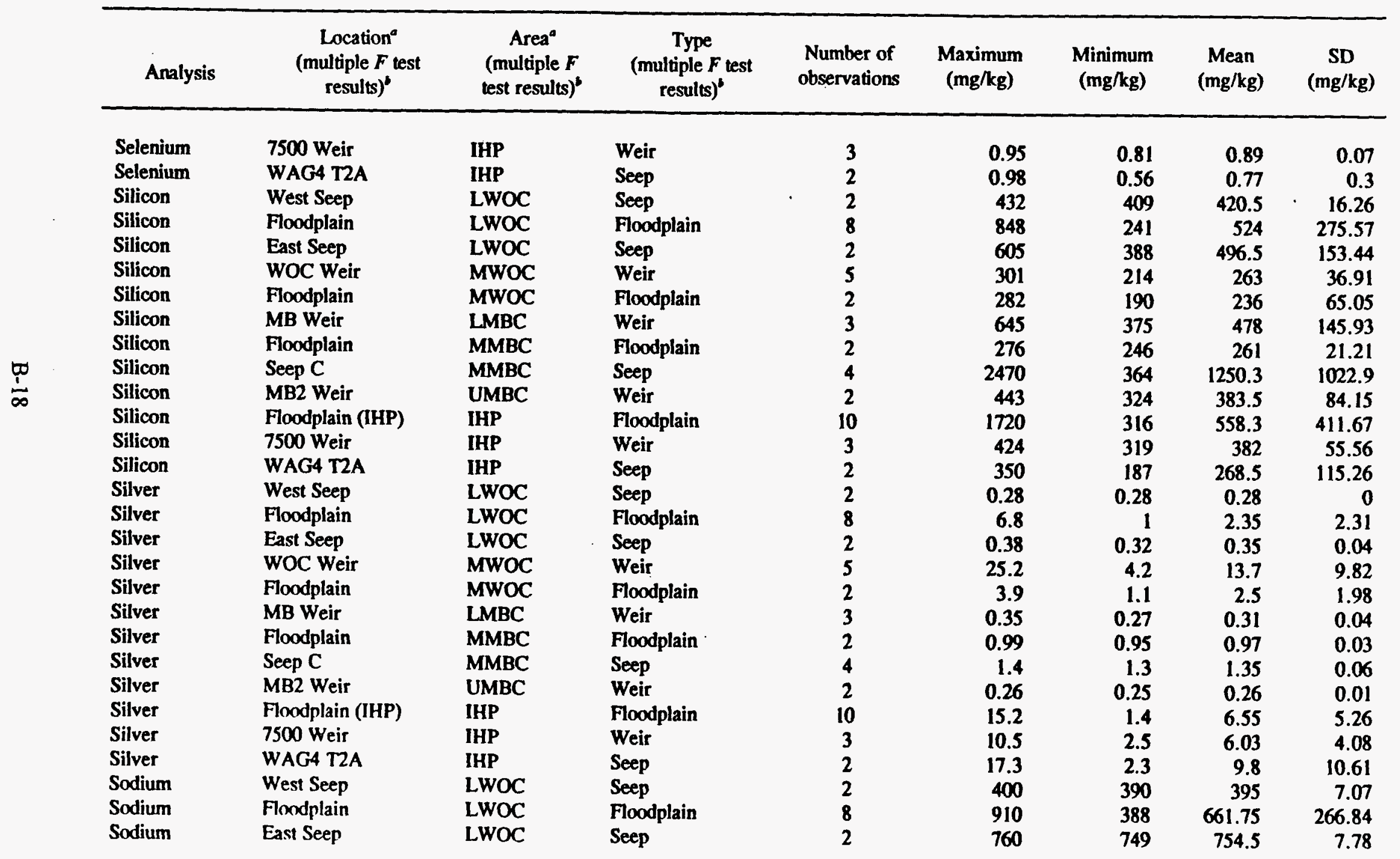


Table B.3 (continued)

\begin{tabular}{|c|c|c|c|c|c|c|c|c|}
\hline Analysis & $\begin{array}{l}\text { Location }^{a} \\
\text { (multiple } F \text { test } \\
\text { results) }\end{array}$ & $\begin{array}{c}\text { Area }^{a} \\
\text { (multiple } F \\
\text { test results) }\end{array}$ & $\begin{array}{c}\text { Type } \\
\text { (multiple } F \text { test } \\
\text { results) }\end{array}$ & $\begin{array}{l}\text { Number of } \\
\text { observations }\end{array}$ & $\begin{array}{l}\text { Maximum } \\
(\mathrm{mg} / \mathrm{kg})\end{array}$ & $\begin{array}{c}\text { Minimum } \\
(\mathrm{mg} / \mathrm{kg})\end{array}$ & $\begin{array}{c}\text { Mean } \\
(\mathrm{mg} / \mathrm{kg})\end{array}$ & $\begin{array}{c}\mathrm{SD} \\
(\mathrm{mg} / \mathrm{kg})\end{array}$ \\
\hline Sodium & wOC Weir & MWOC & Weir & 5 & 381 & 312 & 347.8 & 29.54 \\
\hline Sodium & Floodplain & MWOC & Floodplain & 2 & 424 & 396 & 410 & 19.8 \\
\hline Sodium & MB Weir & LMBC & Weir & 3 & 458 & 338 & 395 & 60.22 \\
\hline Sodium & Floodplain & MMBC & Floodplain & 2 & 375 & 348 & 361.5 & 19.09 \\
\hline Sodium & Seep C & MMBC & Seep & 4 & 531 & 471 & 500.5 & 27.77 \\
\hline Sodium & MB2 Weir & UMBC & Weir & 2 & 364 & 299 & 331.5 & 45.96 \\
\hline Sodium & Floodplain (IHP) & IHP & Floodplain & 10 & 631 & 464 & 518 & 44.16 \\
\hline Sodium & 7500 Weir & IHP & Weir & 3 & 424 & 340 & 394.33 & 47.12 \\
\hline Sodium & WAG4 T2A & IHP & Seep & 2 & 441 & 256 & 348.5 & 130.81 \\
\hline Strontium & West Seep & LWOC & Seep & 2 & 11.2 & 8.5 & 9.85 & 1.91 \\
\hline Strontium & Floodplain & LWOC & Floodplain & 8 & 10.1 & 2 & 5.4 & 3.69 \\
\hline Strontium & East Seep & LWOC & Seep & 2 & 45.8 & 36.8 & 41.3 & 6.36 \\
\hline Strontium & WOC Weir & MWOC & Weir & 5 & 66.7 & 15 & 33.5 & 23.96 \\
\hline Strontium & Floodplain & MWOC & Floodplain & 2 & 11.9 & 6.4 & 9.15 & 3.89 \\
\hline Strontium & MB Weir & LMBC & Weir & 3 & 15.6 & 11.5 & 13.1 & 2.19 \\
\hline Strontium & Floodplain & MMBC & Floodplain & 2 & 7.5 & 7.2 & 7.35 & 0.21 \\
\hline Strontium & Seep C & MMBC & Seep & 4 & 23.3 & 4.1 & 12.93 & 8.2 \\
\hline Strontium & MB2 Weir & UMBC & Weir & 2 & 29.6 & 20.6 & 25.1 & 6.36 \\
\hline Strontium & Floodplain (IHP) & IHP & Floodplain & 10 & 28.8 & 11.4 & 19.05 & 5.01 \\
\hline Strontium & 7500 Weir & IHP & Weir & 3 & 46.5 & 8.8 & 24.47 & 19.64 \\
\hline Strontium & WAG4 T2A & IHP & Seep & 2 & 20.8 & 6.6 & 13.7 & 10.04 \\
\hline Thallium & West Seep & LWOC & Seep & 2 & 0.84 & 0.82 & 0.83 & 0.01 \\
\hline Thallium & Floodplain & LWOC & Floodplain & 8 & 3 & 0.74 & 1.89 & 1.19 \\
\hline Thallium & East Seep & LWOC & Seep & 2 & 1.2 & 0.95 & 1.08 & 0.18 \\
\hline Thallium & WOC Weir & MWOC & Weir & 5 & 0.9 & 0.65 & 0.75 & 0.11 \\
\hline Thallium & Flondplain & MWOC & Floodplain & 2 & 0.86 & 0.79 & 0.83 & 0.05 \\
\hline Thallium & MB Weir & LMBC & Weir & 3 & 1 & 0.81 & 0.9 & 0.1 \\
\hline Thallium & Floodplain & MMBC & Floodplain & 2 & 0.74 & 0.71 & 0.73 & 0.02 \\
\hline Thallium & Seep C & MMBC & Seep & 4 & 1.4 & 1.3 & 1.35 & 0.06 \\
\hline
\end{tabular}


Table B.3 (continued)

\begin{tabular}{|c|c|c|c|c|c|c|c|c|}
\hline Analysis & $\begin{array}{l}\text { Location }^{a} \\
\text { (multiple } F \text { test } \\
\text { results) }\end{array}$ & $\begin{array}{c}\text { Area }^{a} \\
\text { (multiple } F \\
\text { test results) }\end{array}$ & $\begin{array}{c}\text { Type } \\
\text { (multiple } F \text { test } \\
\text { results) }\end{array}$ & $\begin{array}{l}\text { Number of } \\
\text { observations }\end{array}$ & $\begin{array}{l}\text { Maximum } \\
(\mathrm{mg} / \mathrm{kg})\end{array}$ & $\begin{array}{l}\text { Minimum } \\
(\mathrm{mg} / \mathrm{kg})\end{array}$ & $\begin{array}{c}\text { Mean } \\
(\mathrm{mg} / \mathrm{kg})\end{array}$ & $\begin{array}{c}\mathrm{SD} \\
(\mathrm{mg} / \mathrm{kg})\end{array}$ \\
\hline Thallium & MB2 Weir & UMBC & Weir & 2 & 0.78 & 0.75 & 0.77 & 0.02 \\
\hline Thallium & Floodplain (IHP) & IHP & Floodplain & 10 & 1 & 0.76 & 0.85 & 0.07 \\
\hline Thallium & 7500 Weir & IHP & Weir & 3 & 0.95 & 0.81 & 0.89 & 0.07 \\
\hline Thallium & WAG4 T2A & IHP & Seep & 2 & 0.98 & 0.56 & 0.77 & 0.3 \\
\hline Tin & West Seep & LWOC & Seep & 2 & 15.3 & 10.7 & 13 & 3.25 \\
\hline Tin & Floodplain & LWOC & Floodplain & 8 & 29 & 6.7 & 17.98 & 11.79 \\
\hline Tin & East Seep & LWOC & Seep & 2 & 11.1 & 9.3 & 10.2 & 1.27 \\
\hline Tin & wOC Weir & MWOC & Weir & 5 & 10.7 & 6.3 & 7.88 & 1.82 \\
\hline Tin & Floodplain & MWOC & Floodplain & 2 & 7.7 & 7.1 & 7.4 & 0.42 \\
\hline Tin & MB Weir & LMBC & Weir & 3 & 10.2 & 7.8 & 8.87 & 1.22 \\
\hline Tin & Floodplain & MMBC & Floodplain & 2 & 6.7 & 6.4 & 6.55 & 0.21 \\
\hline Tin & Seep C & MMBC & Seep & 4 & 19.1 & 9.3 & 12.48 & 4.49 \\
\hline Tin & MB2 Weir & UMBC & Weir & 2 & 22.5 & 15.2 & 18.85 & 5.16 \\
\hline Tin & Floodplain (IHP) & IHP & Floodplain & 10 & 12.8 & 9.4 & 10.49 & 0.96 \\
\hline Tin & 7500 Weir & IHP & Weir & 3 & 12.2 & 8.7 & 9.9 & 1.99 \\
\hline Tin & WAG4 T2A & IHP & Seep & 2 & 16.2 & 5.8 & 11 & 7.35 \\
\hline Vanadium & West Seep & LWOC & Seep & 2 & 38.3 & 27.9 & 33.1 & 7.35 \\
\hline Vanadium & Floodplain & LWOC & Floodplain & 8 & 20.5 & 4 & 11.29 & 7.85 \\
\hline Vanadium & East Seep & LWOC & Seep & 2 & 25.3 & 22.5 & 23.9 & 1.98 \\
\hline Vanadium & wOC Weir & MWOC & Weir & 5 & 12.8 & 9.3 & 11.76 & 1.4 \\
\hline Vanadium & Floodplain & MWOC & Floodplain & 2 & 18.1 & 14 & 16.05 & 2.9 \\
\hline Vanadium & MB Weir & LMBC & Weir & 3 & 30.4 & 25.8 & 27.53 & 2.5 \\
\hline Vanadium & Floodplain & MMBC & Floodplain & 2 & 18.1 & 16.9 & 17.5 & 0.85 \\
\hline Vanadium & Seep C & MMBC & Seep & 4 & 44.3 & 34.7 & 39.13 & 3.94 \\
\hline Vanadium & MB2 Weir & UMBC & Weir & 2 & 38.6 & 34.9 & 36.75 & 2.62 \\
\hline Vanadium & Floodplain (IHP) & IHP & Floodplain & 10 & 33.7 & 24.3 & 27.59 & 3.34 \\
\hline Vanadium & 7500 Weir & IHP & Weir & 3 & 27.6 & 17 & 23.37 & 5.61 \\
\hline Vanadium & WAG4 T2A & IHP & Seep & 2 & 15.3 & 11.5 & 13.4 & 2.69 \\
\hline Zinc & West Seep & LWOC & Seep & 2 & 75.2 & 58 & 66.6 & 12.16 \\
\hline
\end{tabular}


Table B.3 (continued)

\begin{tabular}{|c|c|c|c|c|c|c|c|c|}
\hline Analysis & $\begin{array}{l}\text { Location }^{a} \\
\text { (multiple } \boldsymbol{F} \text { test } \\
\text { results)" }\end{array}$ & $\begin{array}{c}\text { Area }^{4} \\
\text { (multiple } F \\
\text { test results) }\end{array}$ & $\begin{array}{c}\text { Type } \\
\text { (multiple } F \text { test } \\
\text { results) }\end{array}$ & $\begin{array}{l}\text { Number of } \\
\text { observations }\end{array}$ & $\begin{array}{l}\text { Maximum } \\
\text { (mg/kg) }\end{array}$ & $\begin{array}{l}\text { Minimum } \\
(\mathrm{mg} / \mathrm{kg})\end{array}$ & $\begin{array}{c}\text { Mean } \\
(\mathrm{mg} / \mathrm{kg})\end{array}$ & $\underset{(\mathrm{mg} / \mathrm{kg})}{\mathrm{SD}}$ \\
\hline Zinc & Floodplain & LWOC & Floodplain & 8 & 190 & 4 & 55.19 & 66.65 \\
\hline Zinc & East Seep & LWOC & Seep & 2 & 77.6 & 75.7 & 76.65 & 1.34 \\
\hline Zinc & wOC Weir & MWOC & Weir & 5 & 908 & 254 & 525.8 & 276.07 \\
\hline Zinc & Floodplain & MWOC & Floodplain & 2 & 123 & 44.5 & 83.75 & 55.51 \\
\hline Zinc & MB Weir & LMBC & Weir & 3 & 410 & 151 & 304.67 & 136.1 \\
\hline Zinc & Floodplain & MMBC & Floodplain & 2 & 61.3 & 58.1 & 59.7 & 2.26 \\
\hline Zine & Seep C & MMBC & Seep & 4 & 81.2 & 59.4 & 69.65 & 10.56 \\
\hline Zine & MB2 Weir & UMBC & Weir & 2 & 580 & 501 & 540.5 & 55.86 \\
\hline Zinc & Floodplain (IHP) & IHP & Floodplain & 10 & 159 & 70.6 & 94.67 & 26.78 \\
\hline Zinc & 7500 Weir & IHP & Weir & 3 & 330 & 173 & 260.33 & 79.98 \\
\hline Zinc & WAG4 T2A & IHP & Seep & 2 & 324 & 95.5 & 209.75 & 161.57 \\
\hline
\end{tabular}

THP = Intermediate Holding Pond; LMBC = Lower Melton Branch Creek; LWOC $=$ Lower White Oak Creek; MB = Melton Branch; MMBC = Middle Melton Branch Creek; MWOC = Middle White Oak Creek; UMBC = Upper Melton Branch Creek; WAG = waste area grouping; WOC = White Oak Creek.

'Letters in parentheses (e.g., A, B, C) indicate relative significance of mean values. Means for entries with the same letter are not significantly different $(p>0.05)$. Multiple comparisons tests run only for analytes identified through the human health exposure analysis as contributing to risk in WAG 2. Comparisons not done for all classes (e.g., location, area or type) of a given analysis; comparisons valid only within a given analysis. 
Table B.4. Decay-corrected estimates of ${ }^{137} \mathrm{Cs}$ in the White Oak Creek watershed ${ }^{a}$

\begin{tabular}{|c|c|c|c|c|}
\hline \multirow[b]{2}{*}{ Area } & \multicolumn{2}{|c|}{${ }^{137} \mathrm{Cs}$ estimate (curies) } & \multicolumn{2}{|c|}{ Period of decay } \\
\hline & Initial & At end of decay period & Years $^{b}$ & Number of days \\
\hline Intermediate Pond ${ }^{c}$ & $\begin{array}{l}105 \\
105\end{array}$ & $\begin{array}{l}72.6 \\
64.7\end{array}$ & $\begin{array}{l}1974-90 \\
1990-95\end{array}$ & $\begin{array}{l}5841 \\
1826\end{array}$ \\
\hline White Oak Lake ${ }^{d}$ & $\begin{array}{l}704 \\
704\end{array}$ & $\begin{array}{l}369.4 \\
329.2\end{array}$ & $\begin{array}{l}1962-90 \\
1990-95\end{array}$ & $\begin{array}{r}10221 \\
1826\end{array}$ \\
\hline White Oak Lake ${ }^{e}$ & $\begin{array}{l}591 \\
591\end{array}$ & $\begin{array}{l}458.7 \\
408.8\end{array}$ & $\begin{array}{l}1979-90 \\
1990-95\end{array}$ & $\begin{array}{l}4016 \\
1826\end{array}$ \\
\hline White Oak Lakef & $\begin{array}{l}405 \\
405\end{array}$ & $\begin{array}{l}369.3 \\
329.1\end{array}$ & $\begin{array}{l}1986-90 \\
1990-95\end{array}$ & $\begin{array}{l}1461 \\
1826\end{array}$ \\
\hline White Oak Lake ${ }^{g}$ & $\begin{array}{l}716 \\
716\end{array}$ & $\begin{array}{l}652.9 \\
581.9\end{array}$ & $\begin{array}{l}1986-90 \\
1990-95\end{array}$ & $\begin{array}{l}1461 \\
1826\end{array}$ \\
\hline
\end{tabular}

${ }^{a}$ Data compiled and estimates calculated by A. L. Brenkert (Environmental Sciences Division, Oak Ridge National Laboratory).

b 1990 and 1995 decay-corrected estimates measured in 1962,1979, and 1986 have not been corrected for influx from upgradient WAGS up to 1990 and 1995; such correction would provide better estimates of present day sediment contamination and may be a source of error when comparing these data with data from new studies.

${ }^{c}$ Data from Dahlman and Van Voris (1976), based on an integration of core data up to $62 \mathrm{~cm}$ deep over a 20,000- $\mathrm{m}^{2}(\sim 2$-ha, or 4.9-acre) area of the floodplain; core collected from each $30-\mathrm{m}$ grid intersection for a total of 53 cores.

${ }^{d}$ Data from a 1965 study by Lomenick and Gardiner; 250 2-ft-long cores were collected at random from 44 acres (17.8 ha) of the former White (Oak Lake Bed; these data are considered the most reliable by Blaylock et al. (1993), given the extent of the 250-core sampling program.

'Data from Oakes et al. (1982) were based on 98-cm-thick sediment cores. From these core volumes, a total sediment volume of $1.3 \times 10^{5} \mathrm{~m}^{3}(4.6 \times$ $\left.10^{6} \mathrm{ft}^{3}\right)$ is estimated on the basis of depositional records, a sediment density of $1.1 \mathrm{~g} / \mathrm{cm}^{3}$, and a lake area of $13.3 \mathrm{ha}(32.8 \mathrm{acres})$.

$f^{\prime}$ Data from Loar et al. (1989) corrected from Sherwood and Loar (1987) and based on cores collected by Blaylock and Mohrbacher in 1987, an estimated lake area of 6.88 ha ( 17 acres), and a sediment depth of $0.62 \mathrm{~m}$

${ }^{g}$ Data from Loar et al. (1989) as interpreted by A. L. Brenkert; corrected for a possibly larger lake area in the 1940 s (12.2 ha, $\sim 30$ acres). 


\section{APPENDIX C}

MAP LOCATIONS CORRESPONDING TO SAMPLE

IDENTIFICATION NUMBERS AND SEDIMENT CORE PLOTS FOR ${ }^{137} \mathrm{CS}$ AND ${ }^{60} \mathrm{CO}$ IN THE WHITE OAK CREEK FLOODPLAIN 


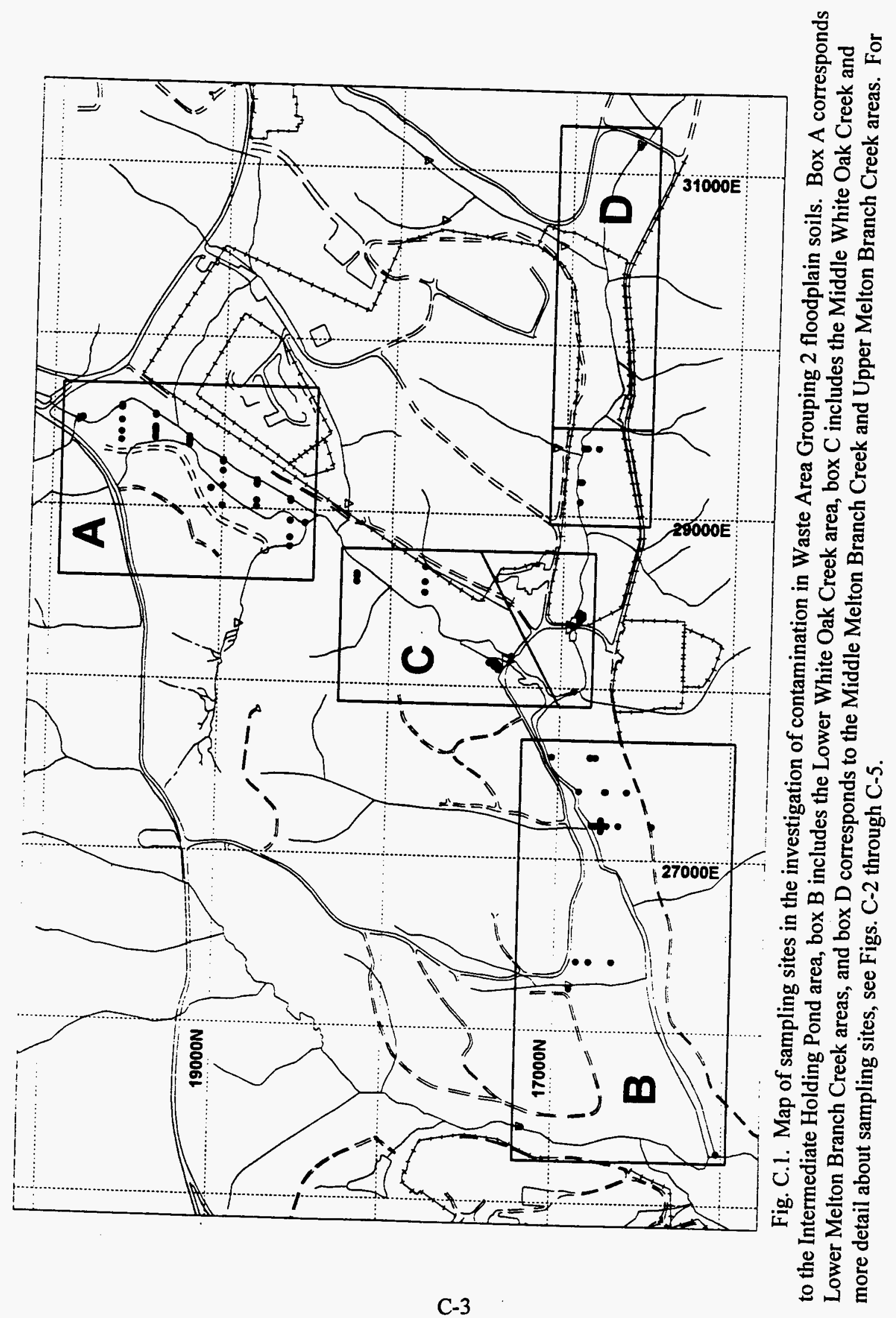




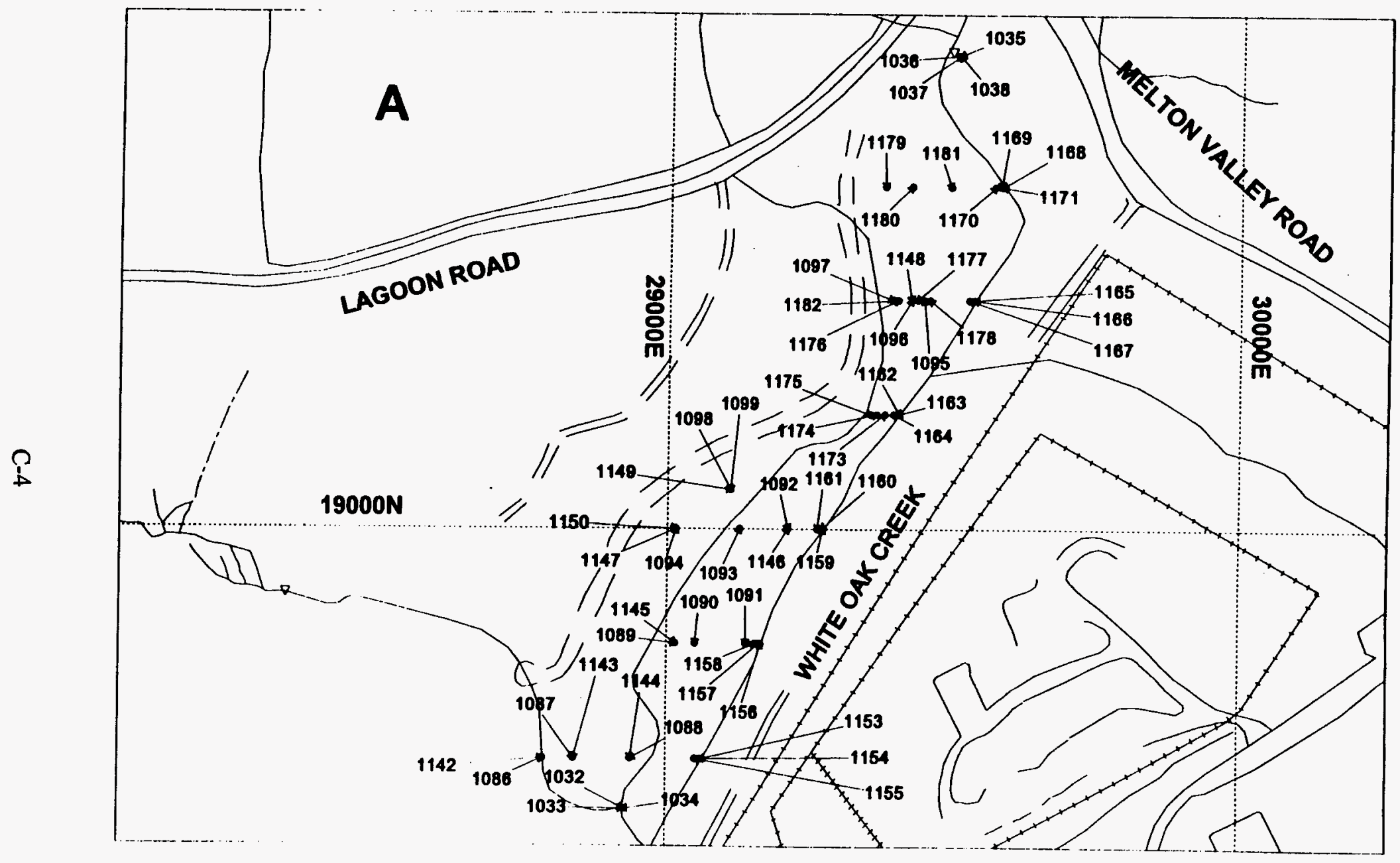

Fig. C.2. Sampling sites and identification numbers of samples collected in the Intermediate Holding Pond area (Fig. C-1, box A) as part of the investigation of contamination in Waste Area Grouping 2 floodplain soils. Samples were submitted for radiological, inorganic, and organic analyses. The map coordinates are based on the Oak Ridge National Laboratory grid coordinate system. 


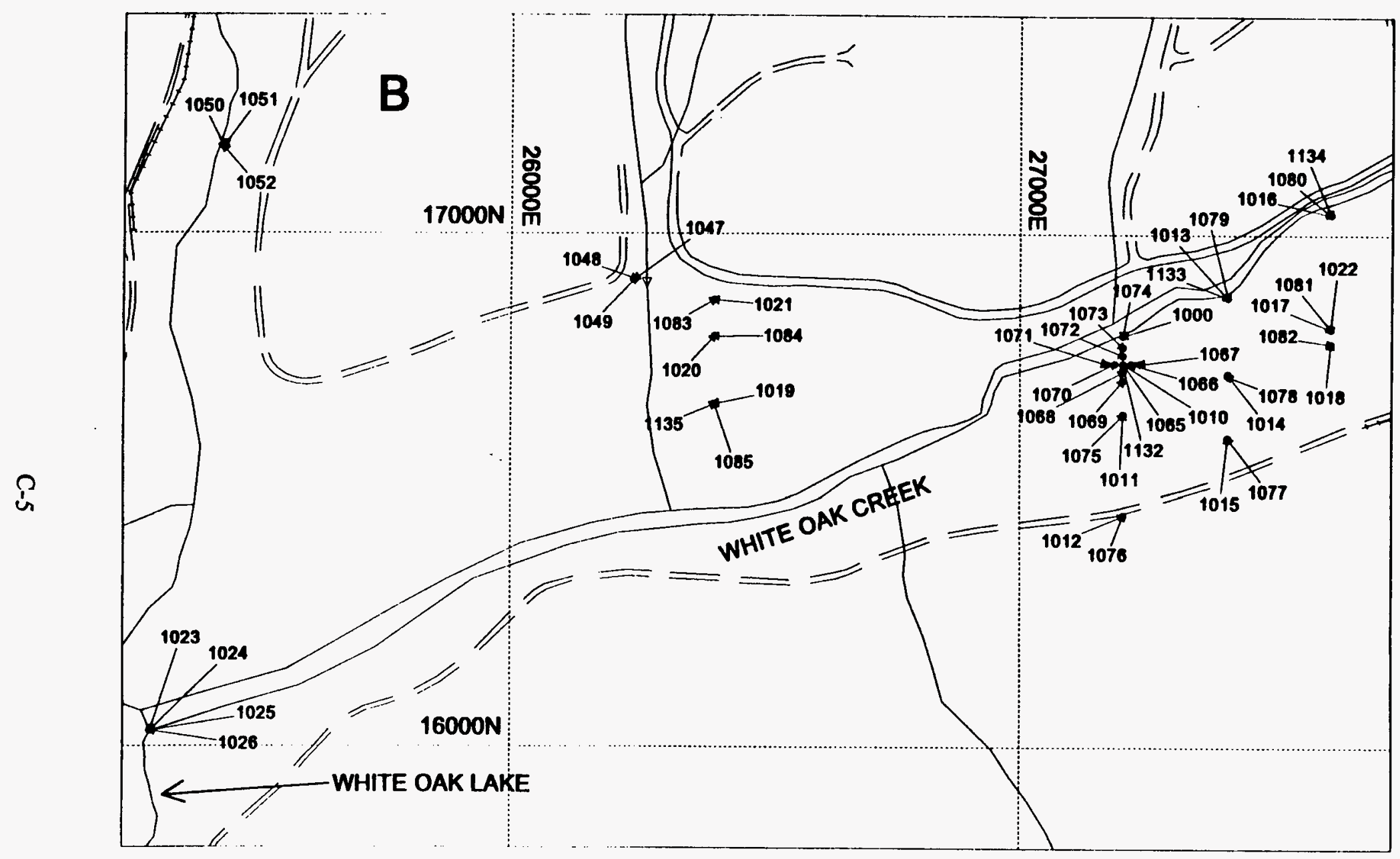

Fig. C.3. Sampling sites and identification numbers of samples collected in the Lower White Oak Creek area (Fig. C-1, box B) as part of the investigation of contamination in Waste Area Grouping 2 floodplain soils. Samples were submitted for radiological, inorganic, and organic analyses. Samples 1000 and 1010, collected from White Oak Lake, were excluded. The map coordinates are based on the Oak Ridge National Laboratory grid coordinate system. 


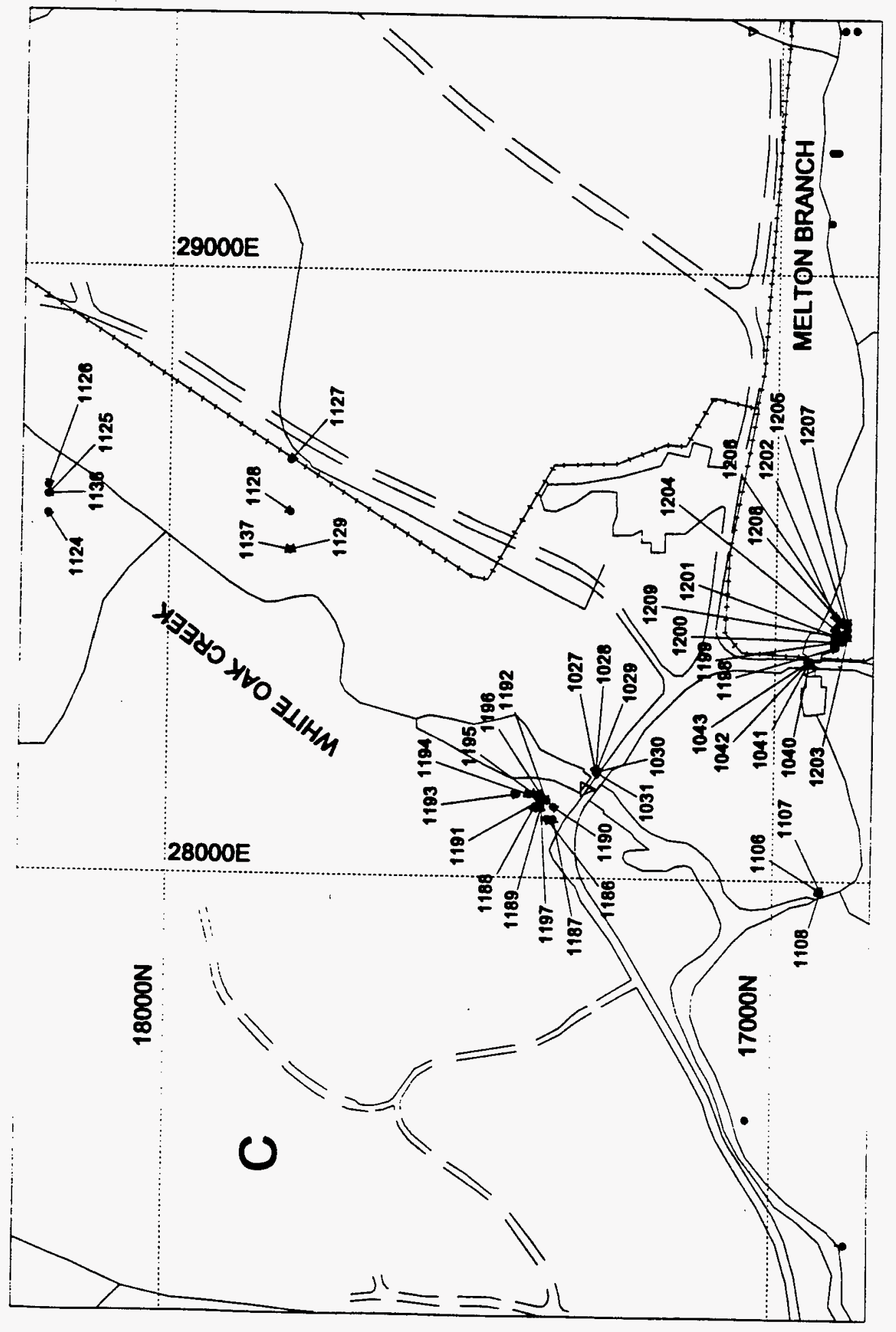

C-6

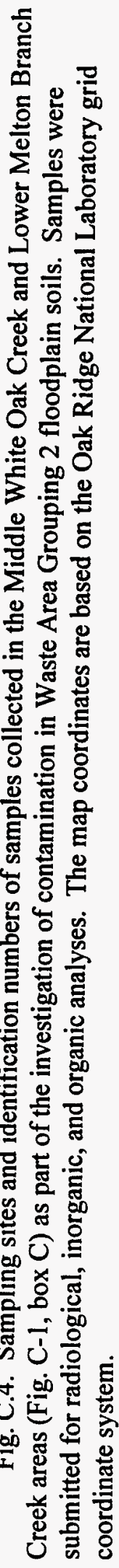




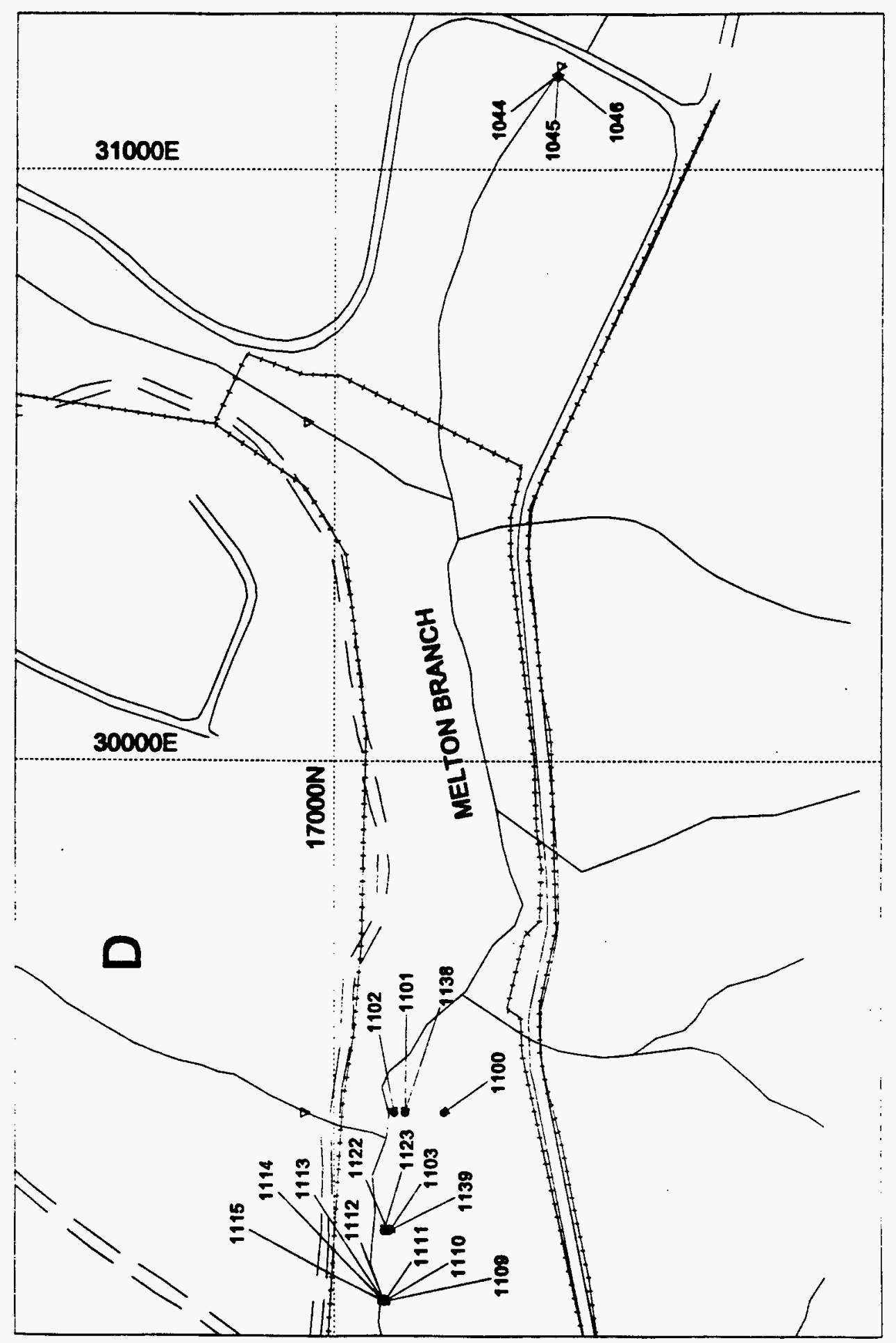

C-7

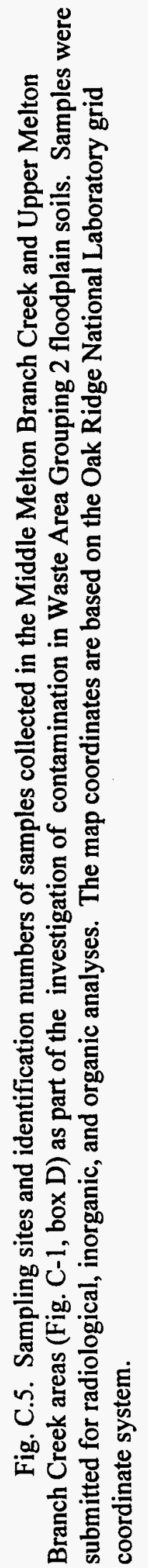



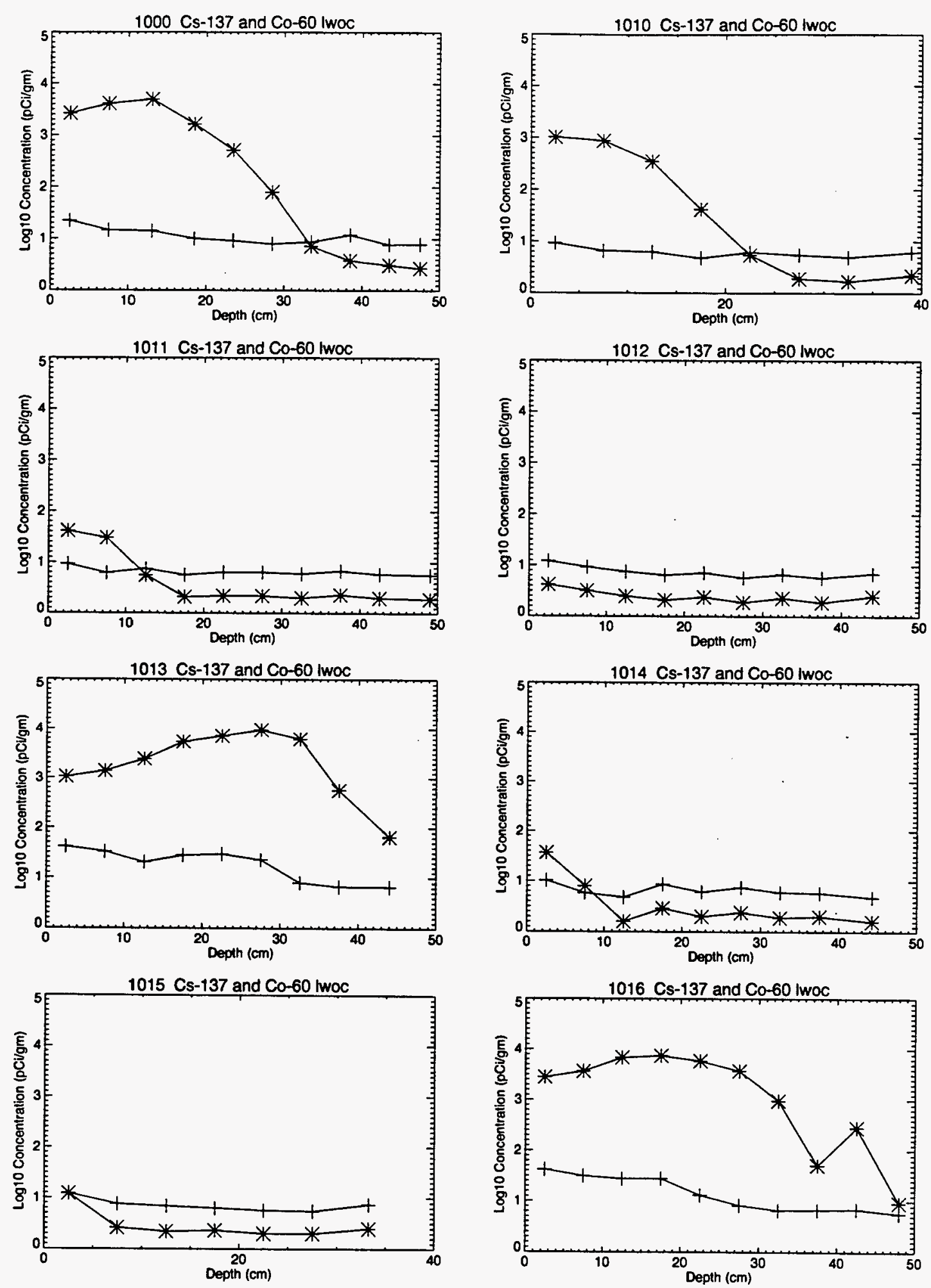

Fig. C.6. Plots of ${ }^{137} \mathrm{Cs}$ concentrations (asterisks) and ${ }^{60} \mathrm{Co}$ concentrations (stars) in sediment sampled during 1995 at sites 1000, 1010, 1011, 1012, 1013, 1014, 1015, and 1016. 
1017 Cs-137 and Co-60 Iwoc
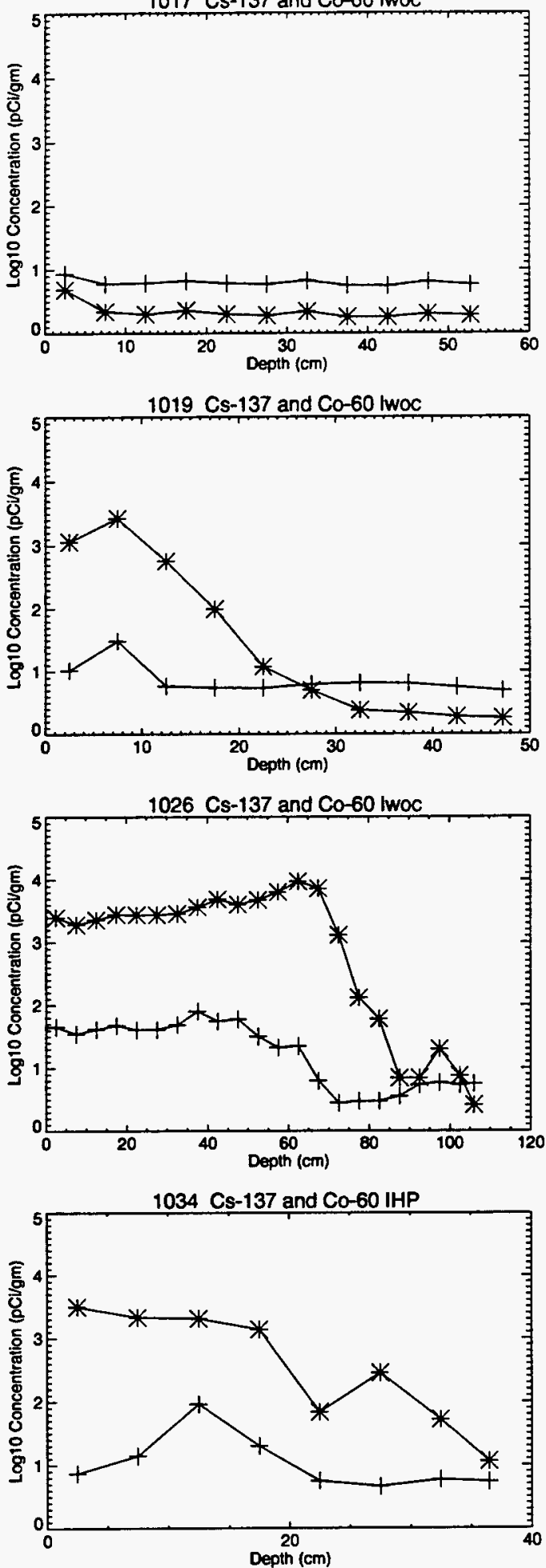

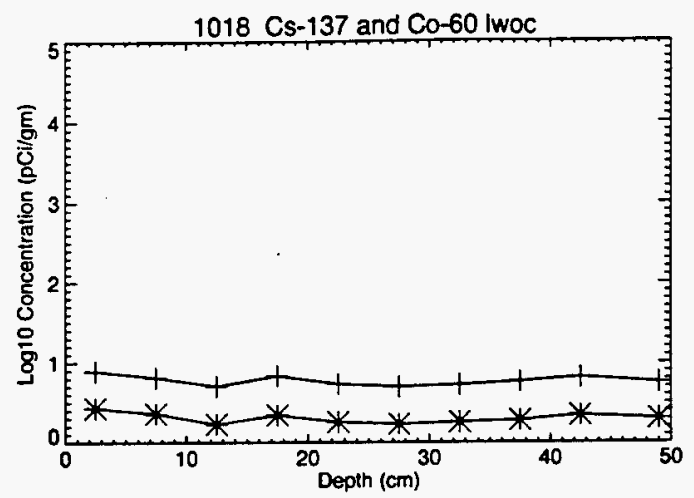

1020 Cs-137 and Co-60 IwOC
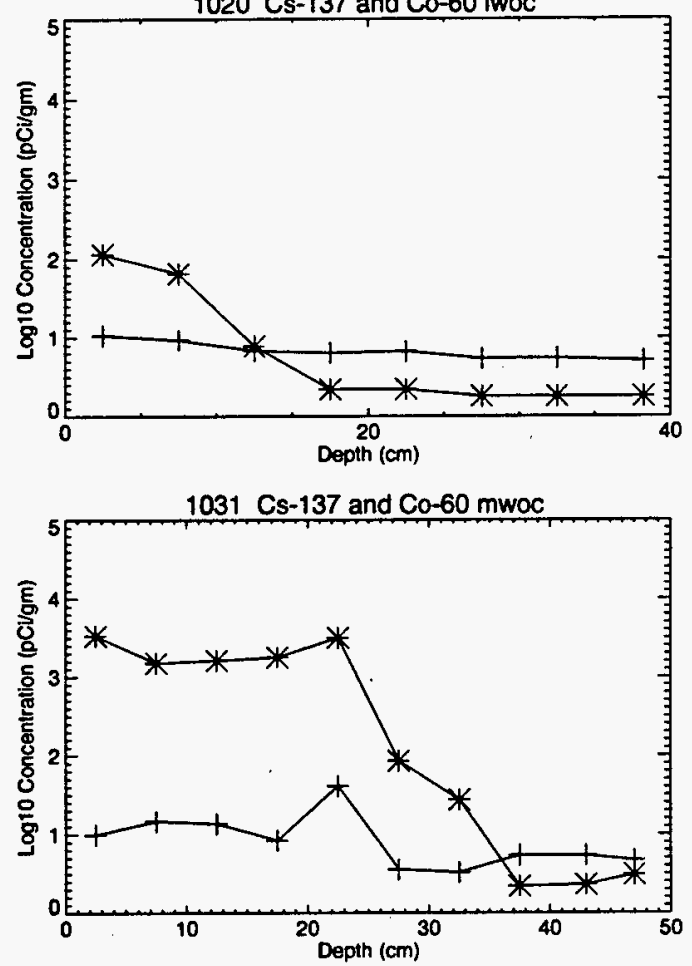

1038 Cs-137 and Co-60 IHP

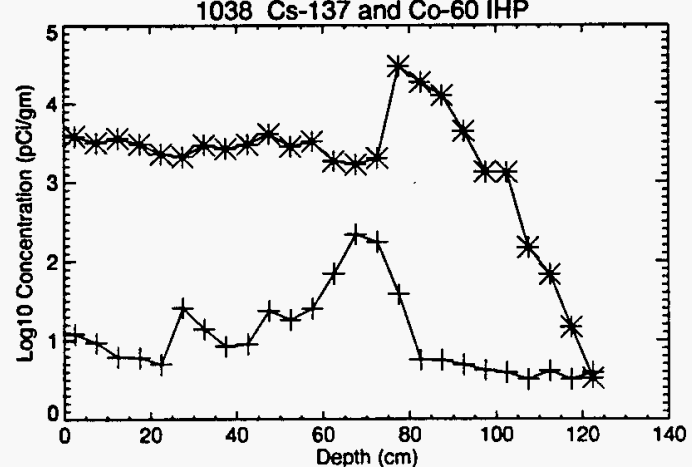

Fig. C.7. Plots of ${ }^{137} \mathrm{Cs}$ concentrations (asterisks) and ${ }^{60} \mathrm{Co}$ concentrations (stars) in sediment sampled during 1995 at sites 1017, 1018, 1019, 1020, 1026, 1031, 1034, and 1038 . 

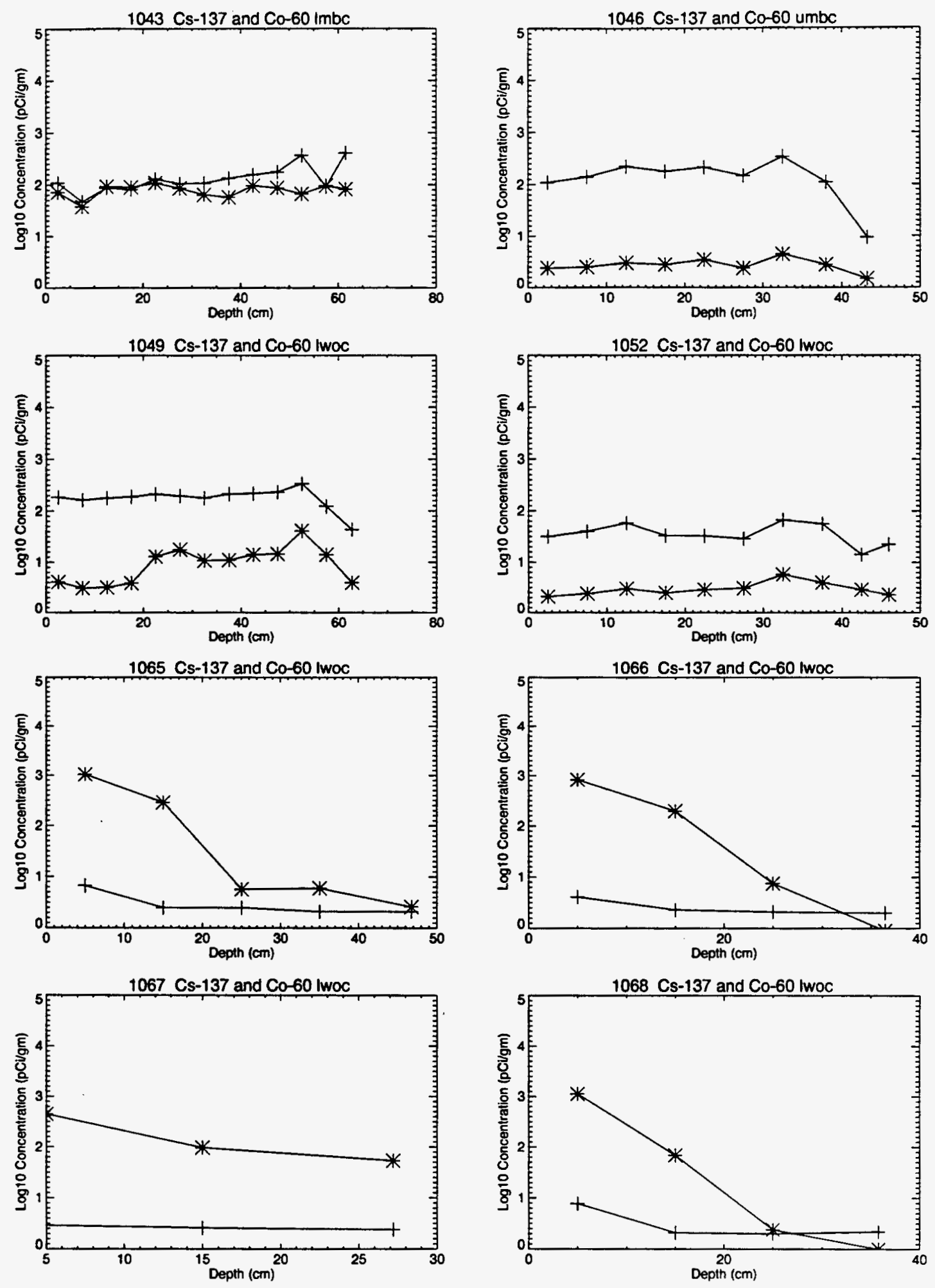

Fig. C.8. Plots of ${ }^{137} \mathrm{Cs}$ concentrations (asterisks) and ${ }^{60} \mathrm{Co}$ concentrations (stars) in sediment sampled during 1995 at sites 1043, 1046, 1049, 1052, 1065, 1066, 1067, and 1068. 

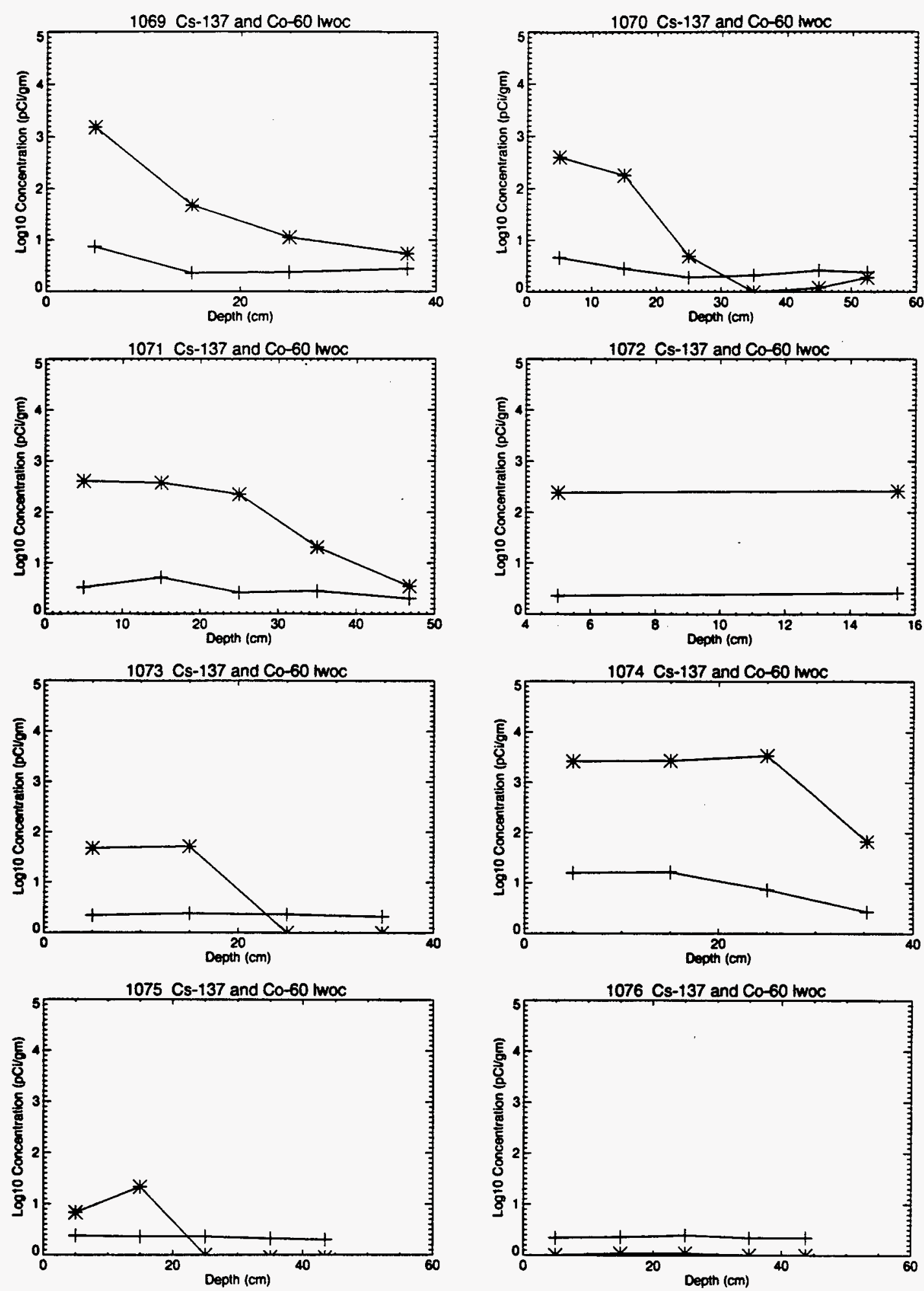

Fig. C.9. Plots of ${ }^{137} \mathrm{Cs}$ concentrations (asterisks) and ${ }^{60} \mathrm{Co}$ concentrations (stars) in sediment sampled during 1995 at sites 1069, 1070, 1072, 1073, 1074, 1075, and 1076. 

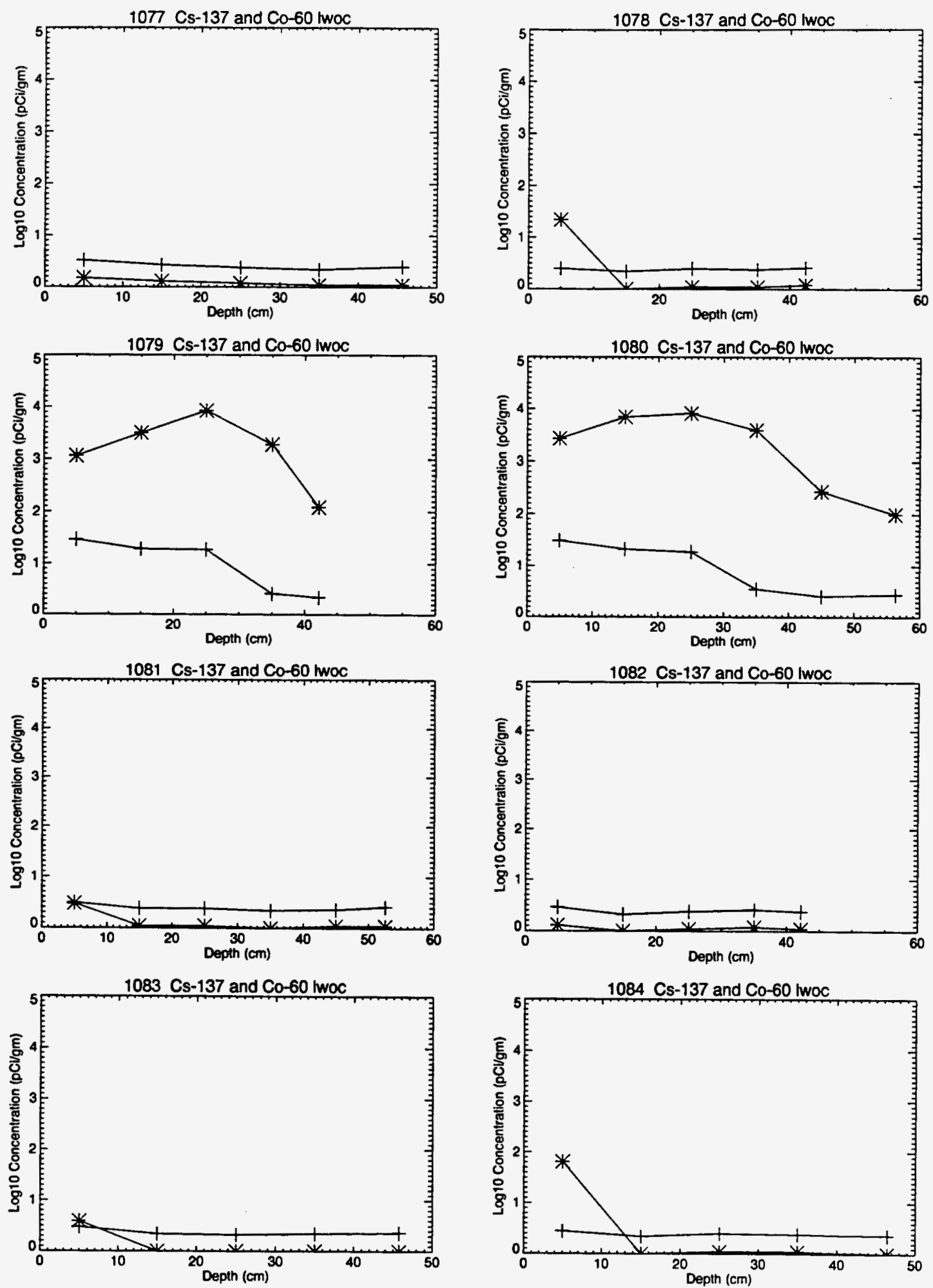

Fig. C.10. Plots of ${ }^{137} \mathrm{Cs}$ concentrations (asterisks) and ${ }^{60} \mathrm{Co}$ concentrations (stars) in sediment sampled during 1995 at sites 1077, 1078, 1079, 1080, 1081, 1082, 1083, and 1084. 

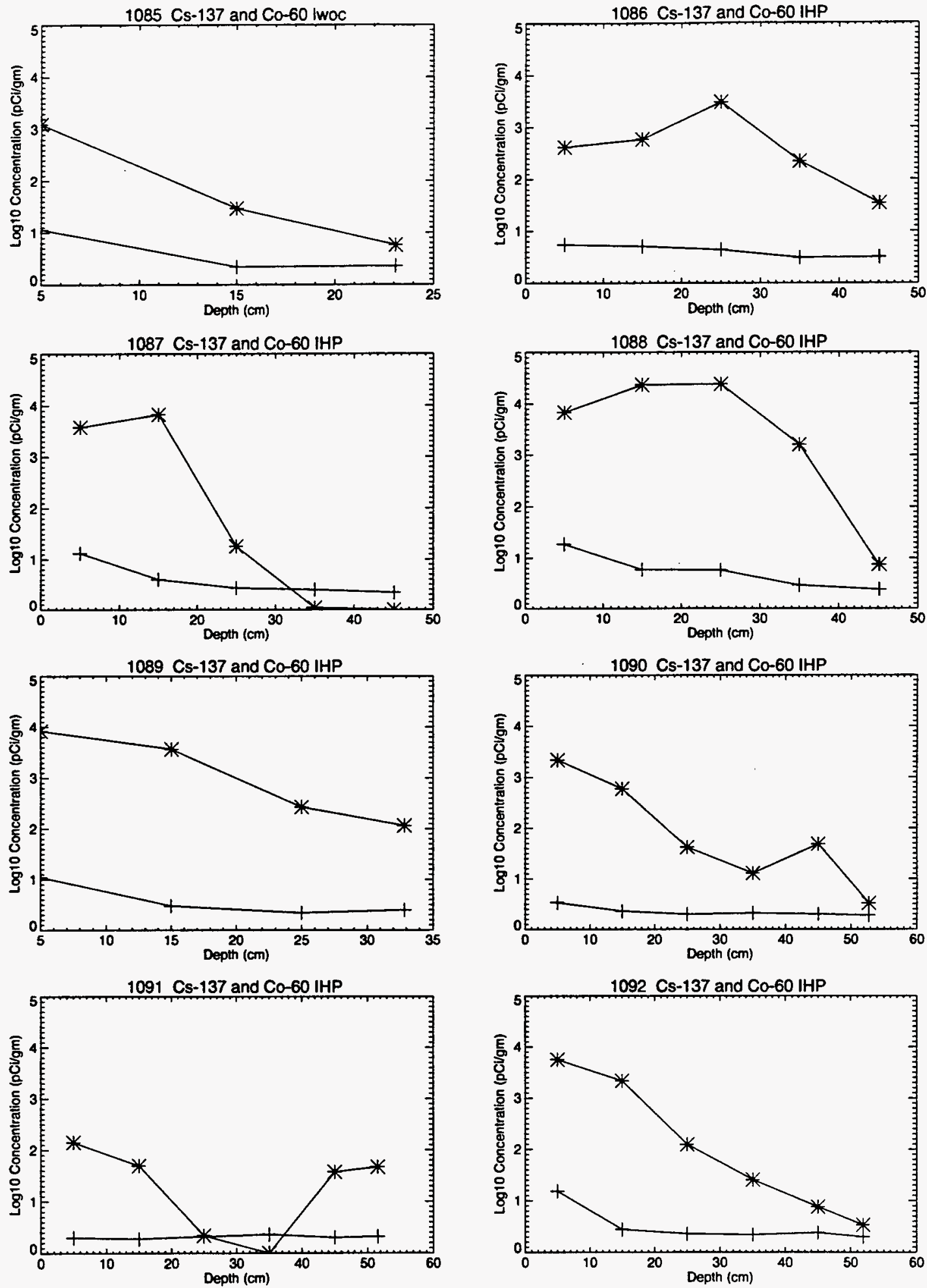

Fig. C.11. Plots of ${ }^{137} \mathrm{Cs}$ concentrations (asterisks) and ${ }^{60} \mathrm{Co}$ concentrations (stars) in sediment sampled during 1995 at sites 1085, 1086, 1087, 1088, 1089, 1090, 1091, and 1092. 

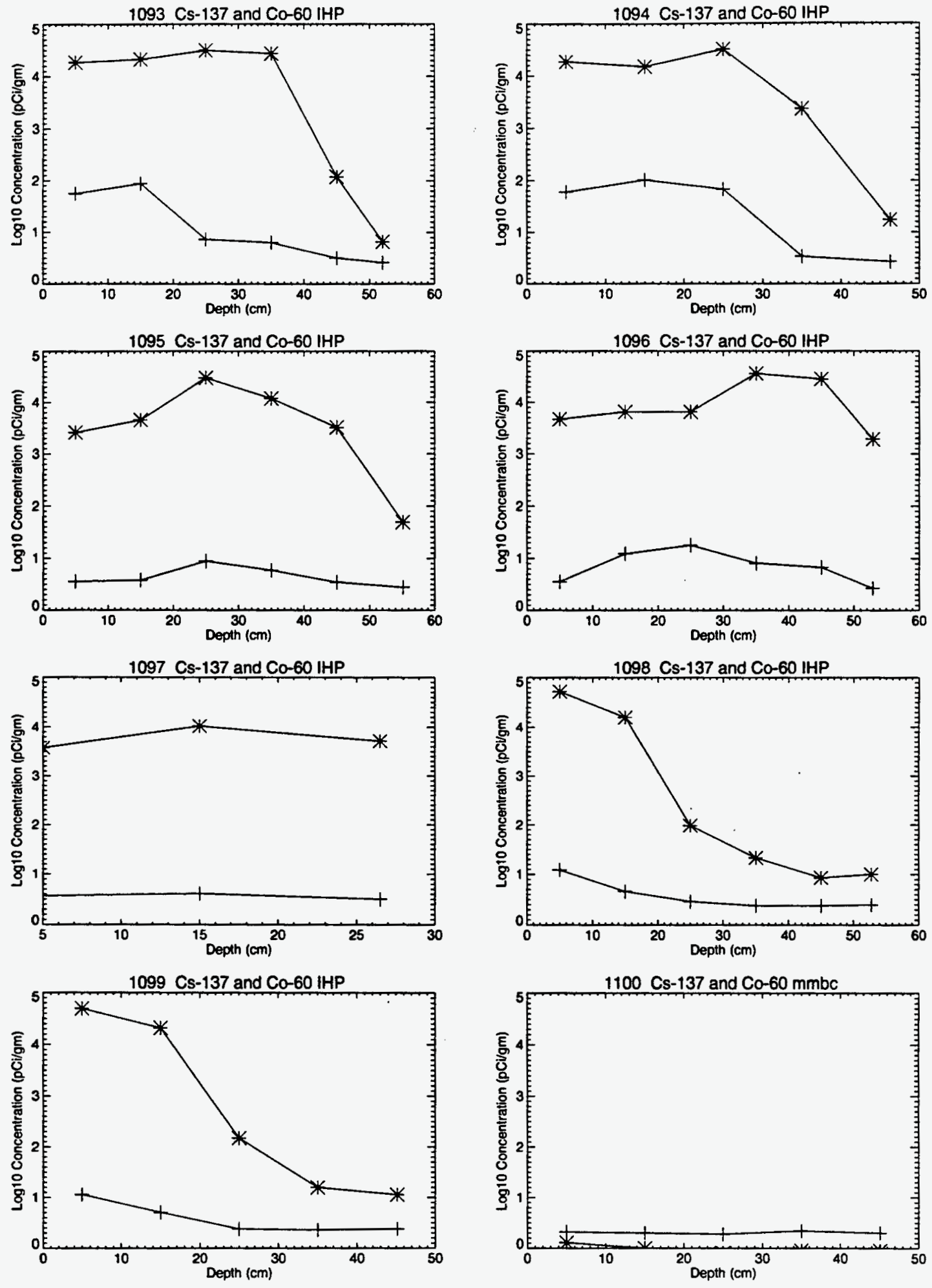

Fig. C.12. Plots of ${ }^{137} \mathrm{Cs}$ concentrations (asterisks) and ${ }^{60} \mathrm{Co}$ concentrations (stars) in sediment sampled during ${ }^{*} 1995$ at sites 1093, 1094, 1095, 1096, 1097, 1098, 1099, and 1100 . 

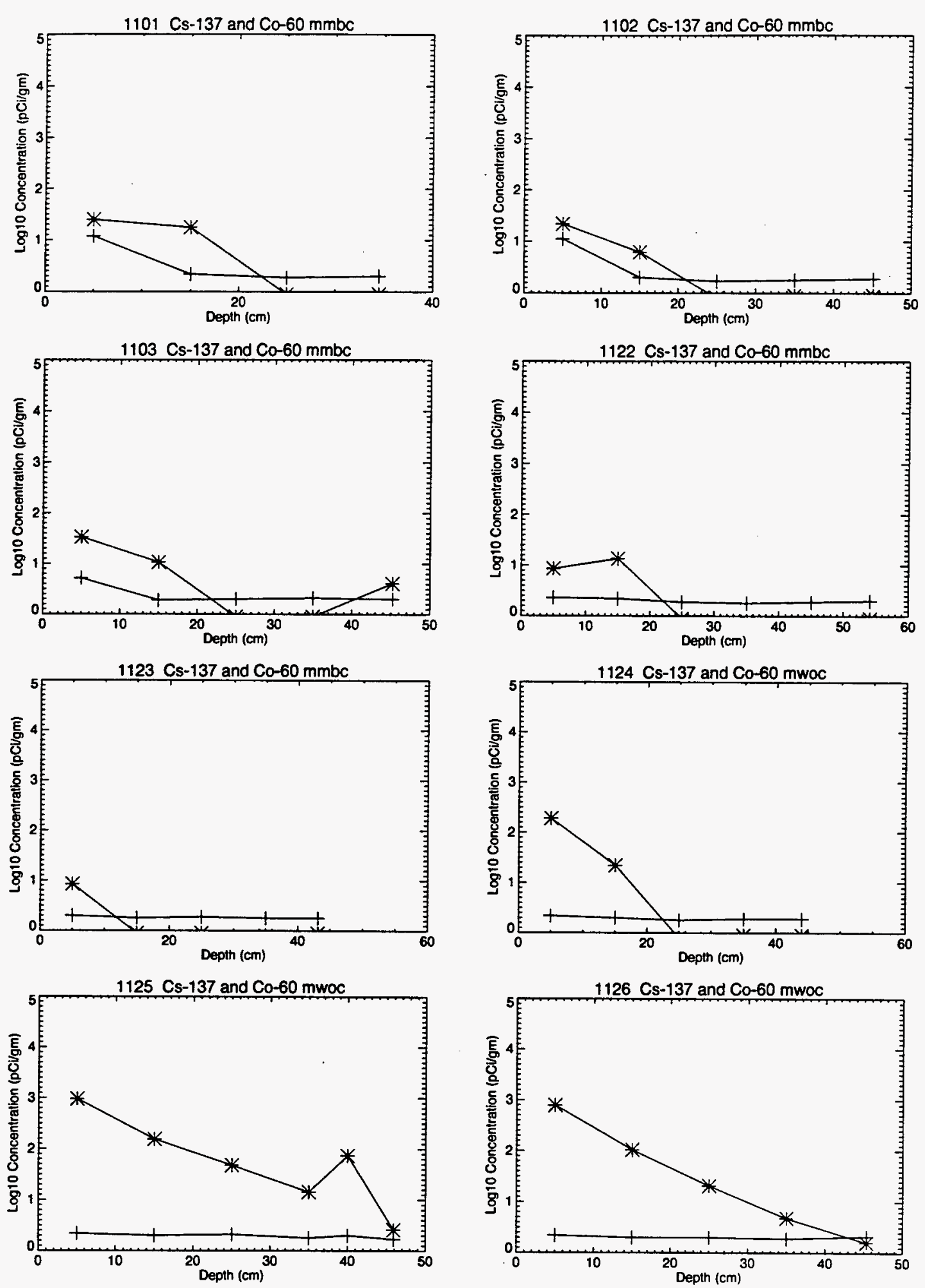

Fig. C.13. Plots of ${ }^{137} \mathrm{Cs}$ concentrations (asterisks) and ${ }^{60} \mathrm{Co}$ concentrations (stars) in sediment sampled during 1995 at sites $1101,1102,1103,1122,1123,1124,1125$, and 1126. 

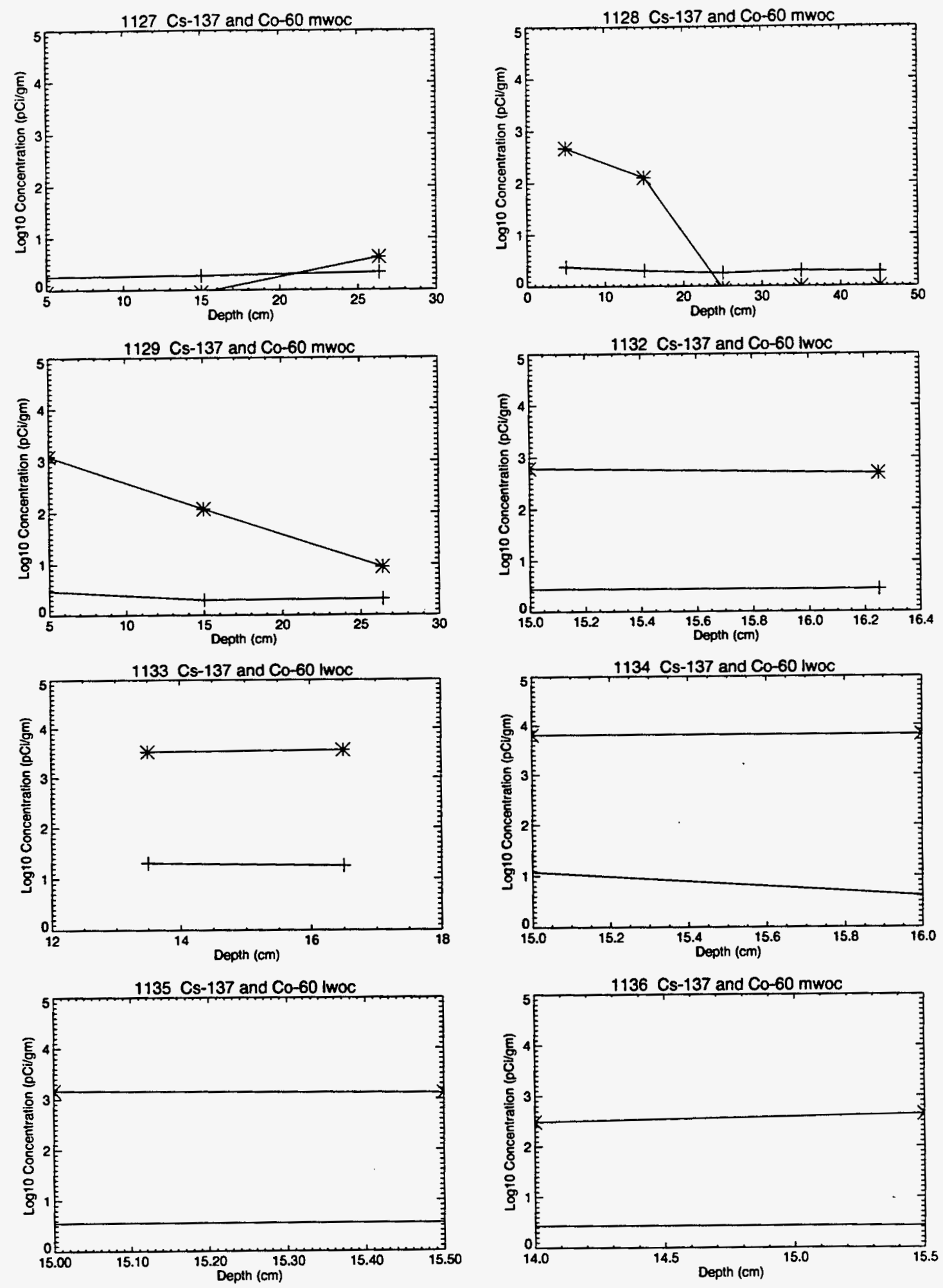

Fig. C.14. Plots of ${ }^{137} \mathrm{Cs}$ concentrations (asterisks) and ${ }^{60} \mathrm{Co}$ concentrations (stars) in sediment sampled during 1995 at sites $1127,1128,1129,1132,1133,1134,1135$, and 1136 . 
1137 Cs-137 and Co-60 mwoc

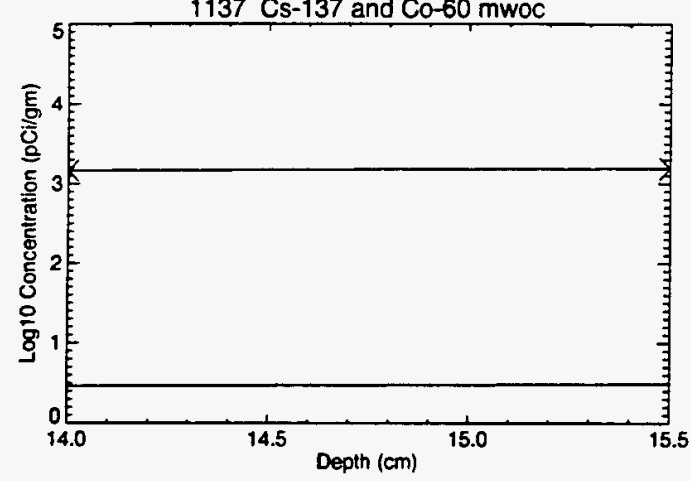

1139 Cs-137 and Co-60 mmbc

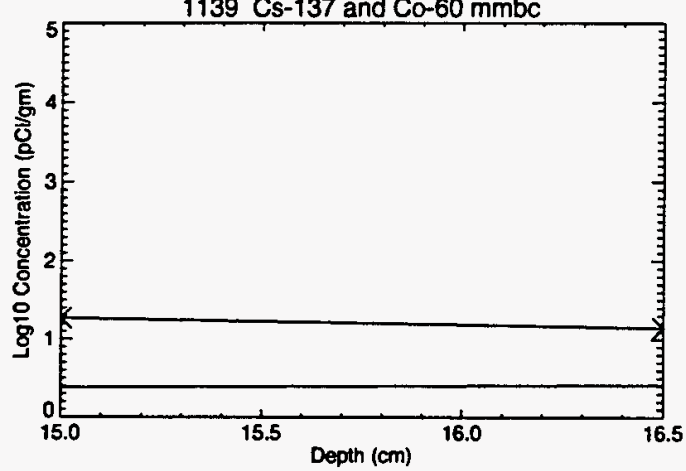

1144 Cs-137 and Co-60 IHP
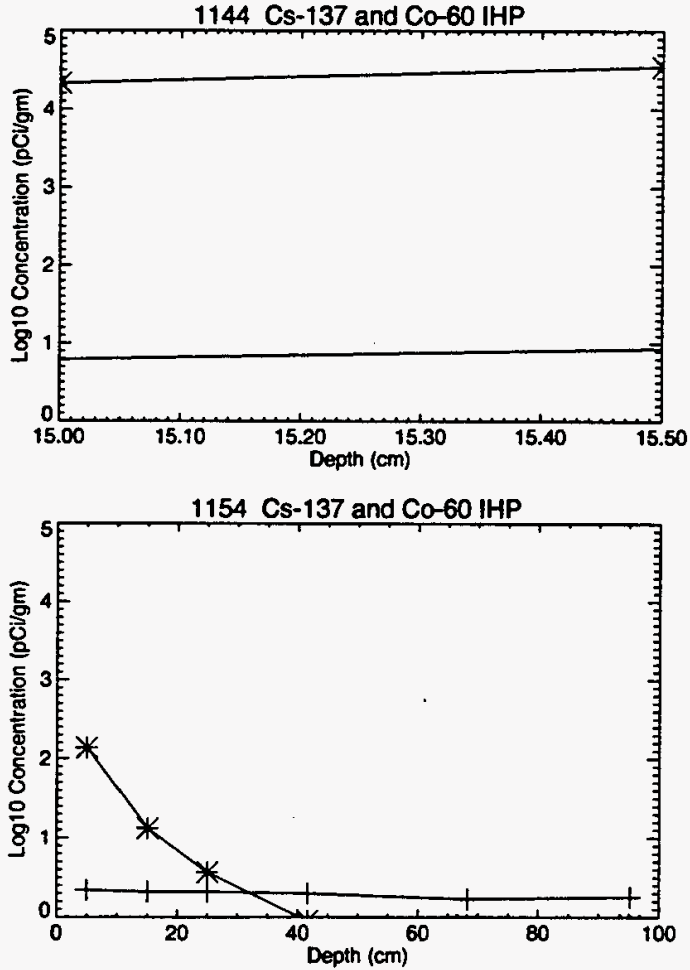

$1138 \mathrm{Cs}-137$ and Co-60 mmbc

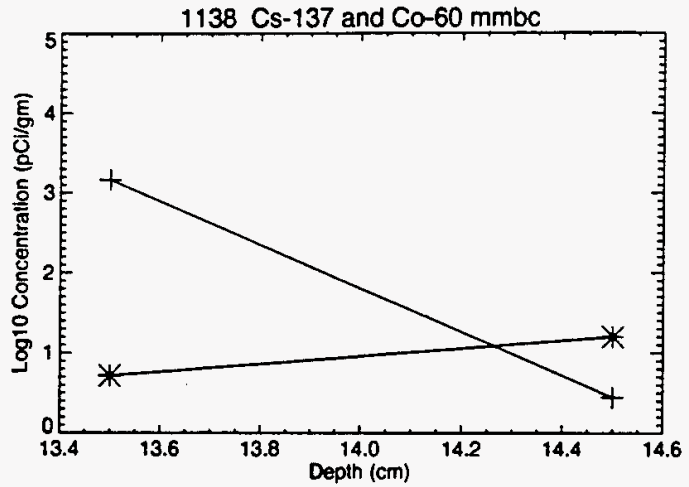

1142 Cs-137 and Co-60 IHP
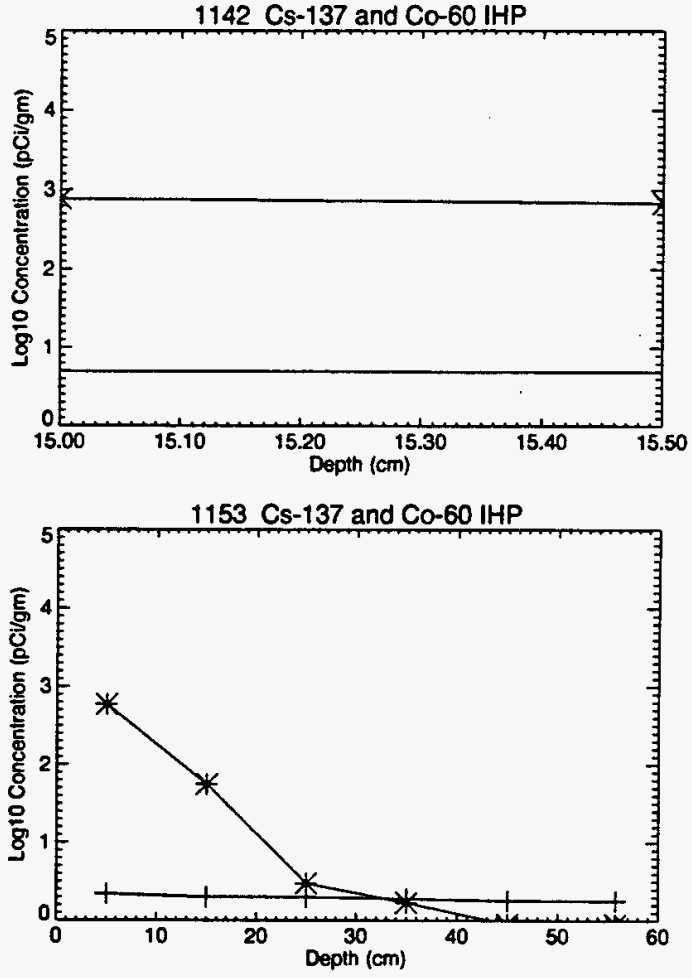

1155 Cs-137 and Co-60 IHP

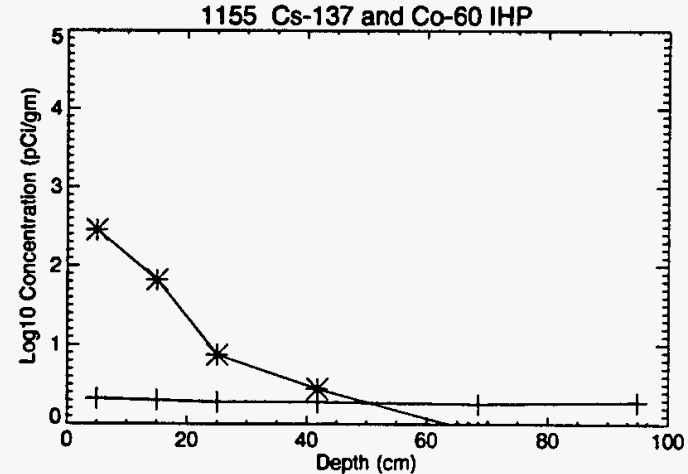

Fig. C.15. Plots of ${ }^{137} \mathrm{Cs}$ concentrations (asterisks) and ${ }^{60} \mathrm{Co}$ concentrations (stars) in sediment sampled during 1995 at sites $1137,1138,1139,1142,1144,1153,1154$, and 1155 . 

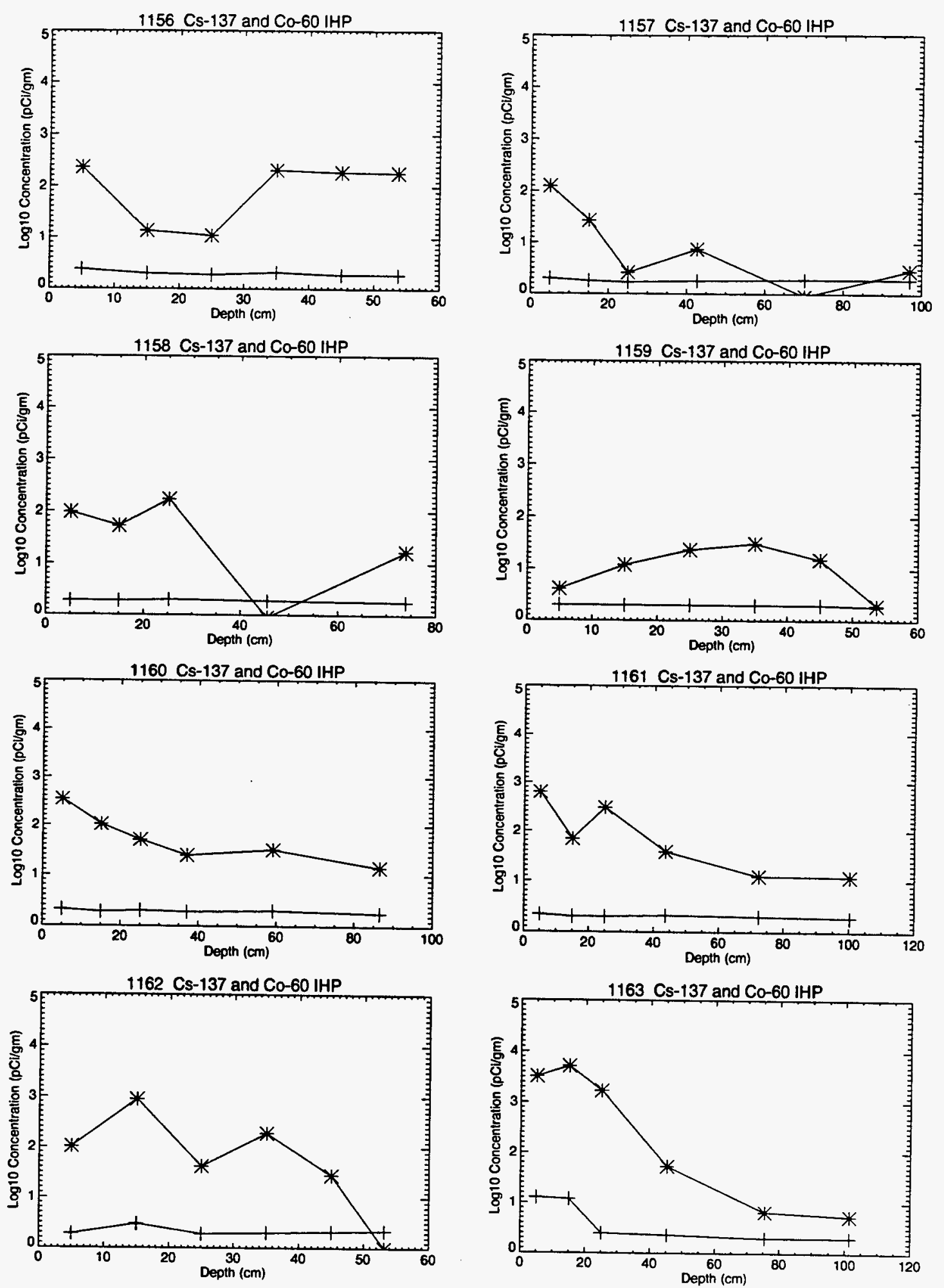

Fig. C.16. Plots of ${ }^{137} \mathrm{Cs}$ concentrations (asterisks) and ${ }^{60} \mathrm{Co}$ concentrations (stars) in sediment sampled during 1995 at sites $1156,1157,1158,1159,1160,1161,1162$, and 1163 . 

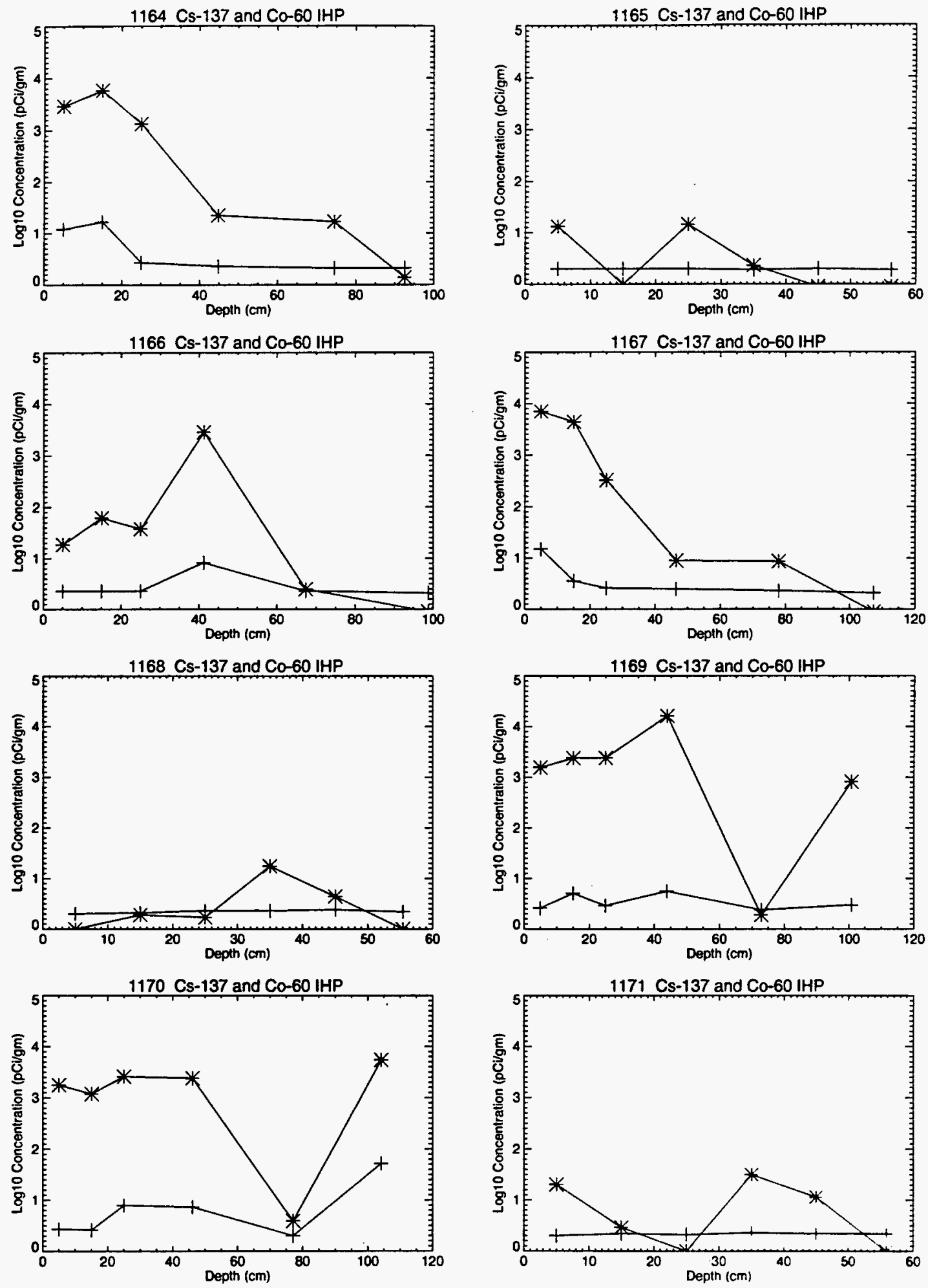

Fig. C.17. Plots of ${ }^{137} \mathrm{Cs}$ concentrations (asterisks) and ${ }^{60} \mathrm{Co}$ concentrations (stars) in sediment sampled during 1995 at sites $1164,1165,1166,1167,1168,1169,1170$, and 1171 . 

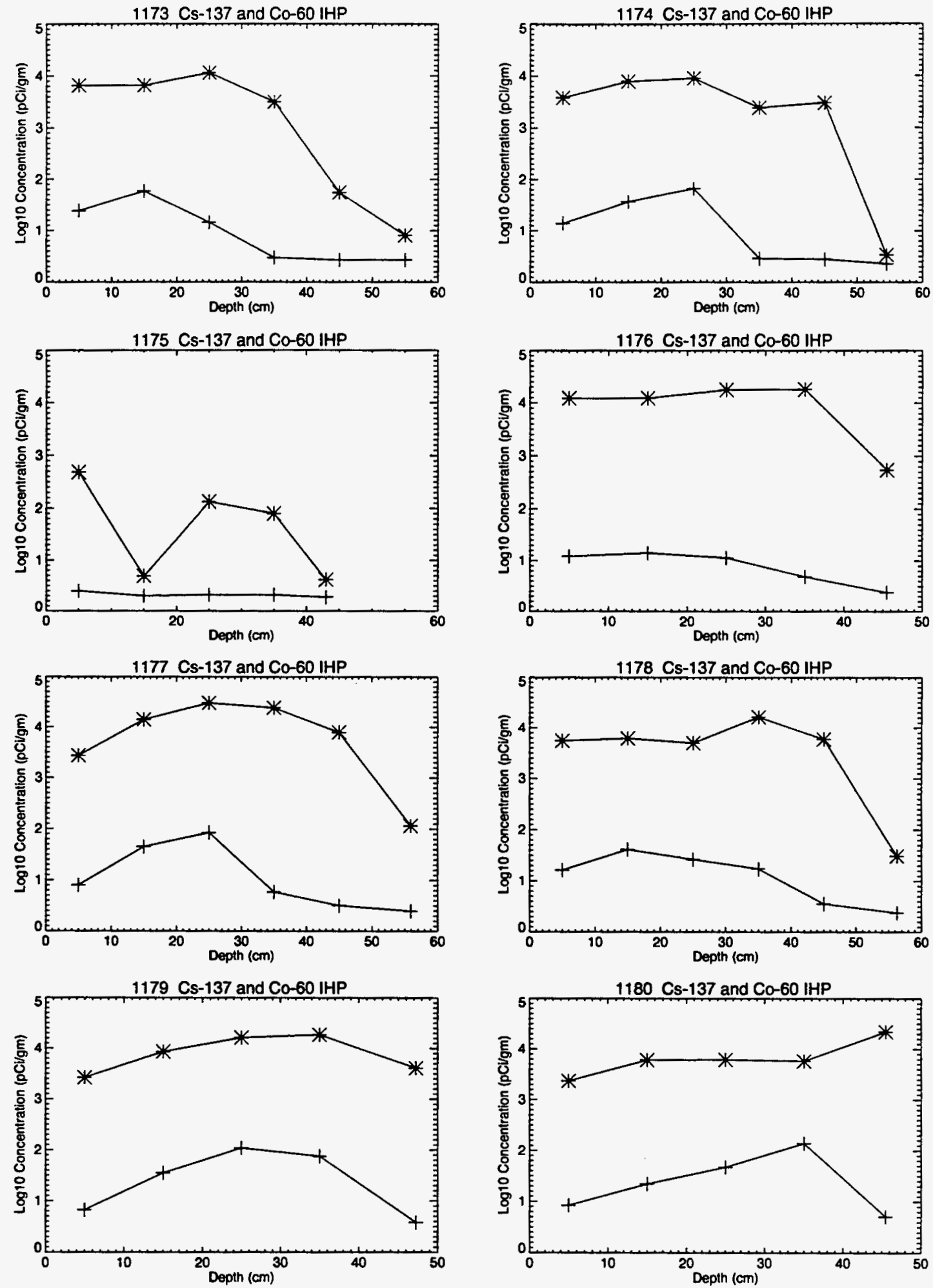

Fig. C.18. Plots of ${ }^{137} \mathrm{Cs}$ concentrations (asterisks) and ${ }^{60} \mathrm{Co}$ concentrations (stars) in sediment sampled during 1995 at sites $1173,1174,1175,1176,1177,1178,1179$, and 1180 . 
1181 Cs-137 and Co-60 IHP

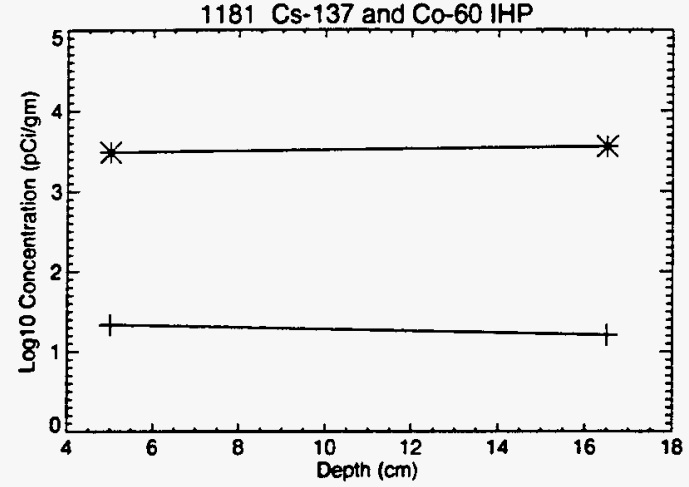

1186 Cs-137 and Co-60 mwoc

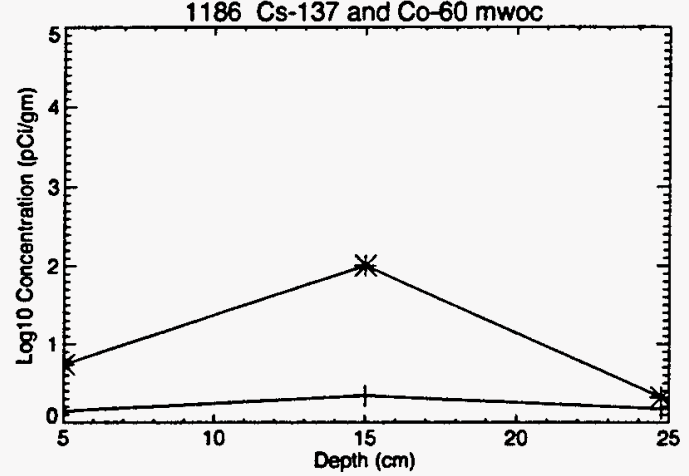

$1188 \mathrm{Cs}-137$ and $\mathrm{Co}-60 \mathrm{mwoc}$

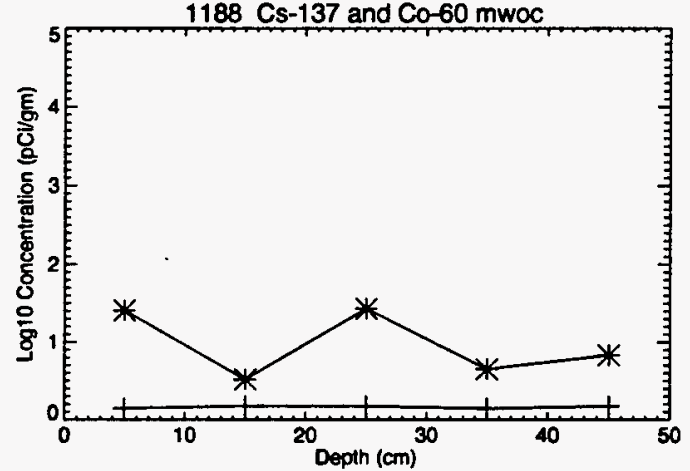

$1190 \mathrm{Cs}-137$ and Co-60 mwoc

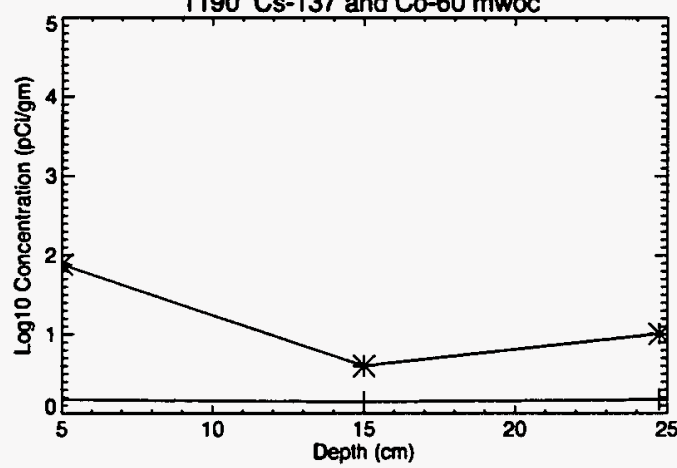

$1182 \mathrm{Cs}-137$ and $\mathrm{Co}-60 \mathrm{IHP}$

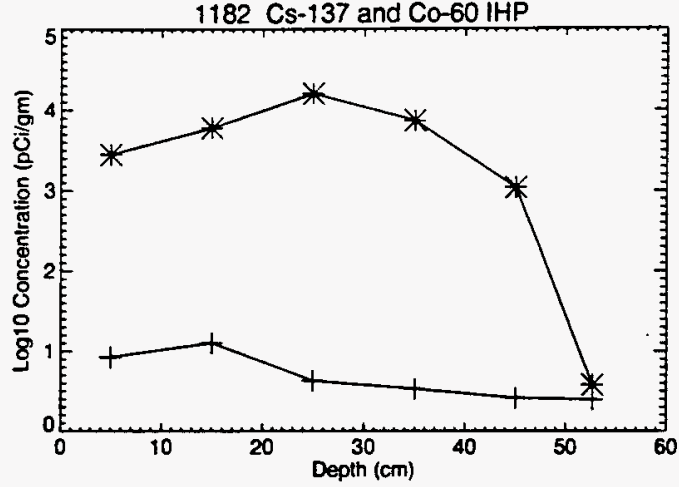

$1187 \mathrm{Cs}-137$ and $\mathrm{Co}-60 \mathrm{mwoc}$
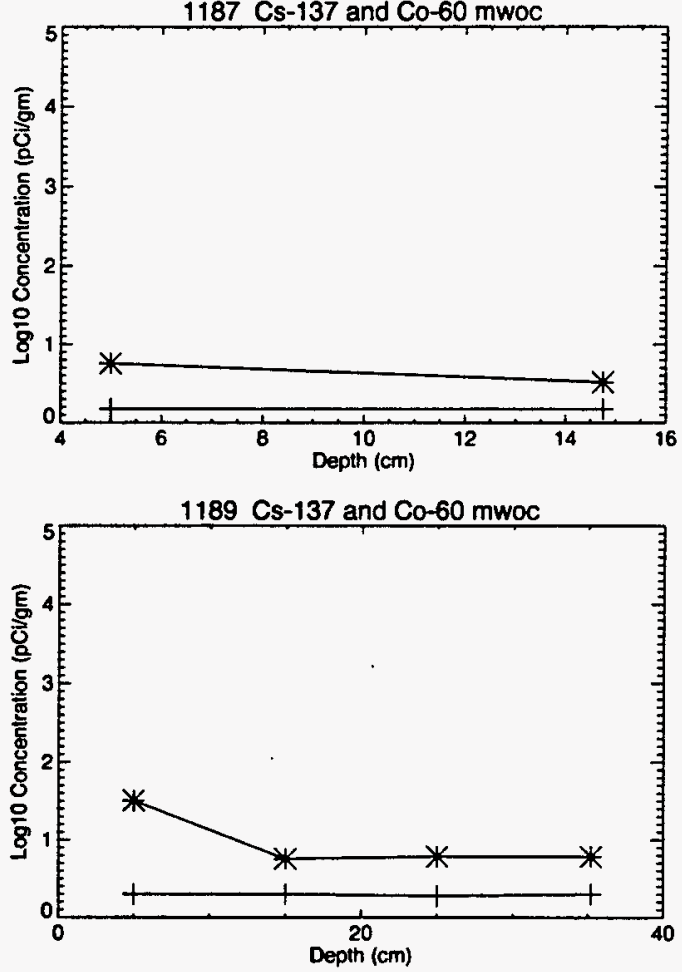

1191 Cs-137 and Co-60 mwoc

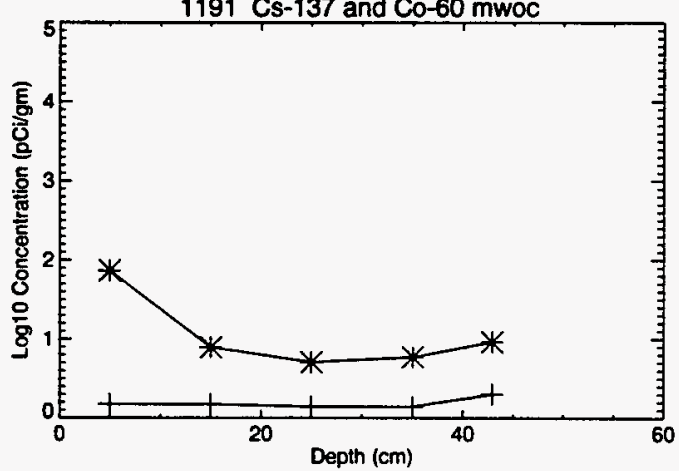

Fig. C.19. Plots of ${ }^{137} \mathrm{Cs}$ concentrations (asterisks) and ${ }^{60} \mathrm{Co}$ concentrations (stars) in sediment sampled during 1995 at sites $1181,1182,1186,1187,1188,1189,1190$, and 1191 . 

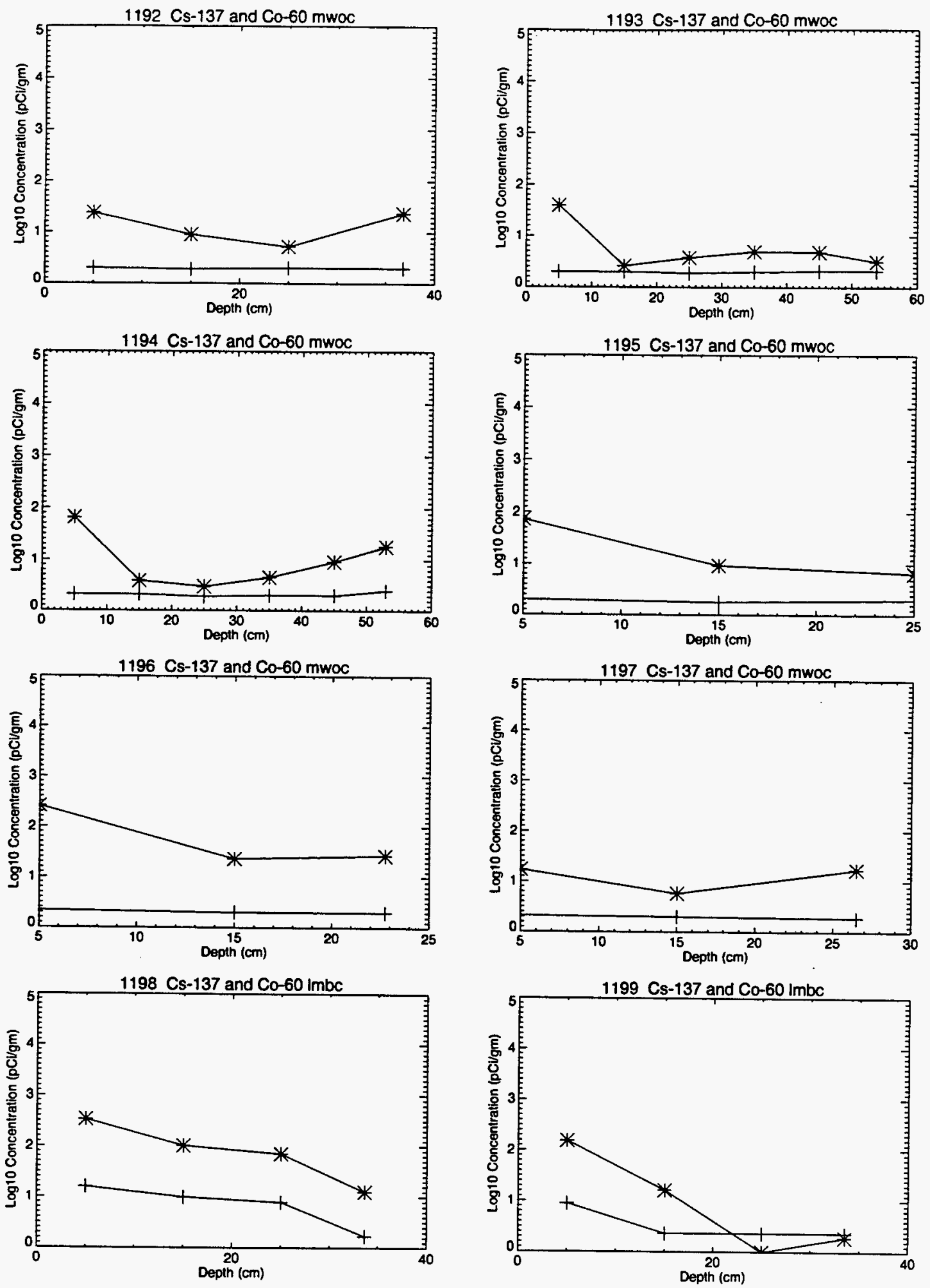

Fig. C.20. Plots of ${ }^{137} \mathrm{Cs}$ concentrations (asterisks) and ${ }^{60} \mathrm{Co}$ concentrations (stars) in sediment sampled during 1995 at sites 1192, 1193, 1194, 1195, 1196, 1197, 1198, and 1199. 
$1200 \mathrm{Cs}-137$ and Co-60 Imbc
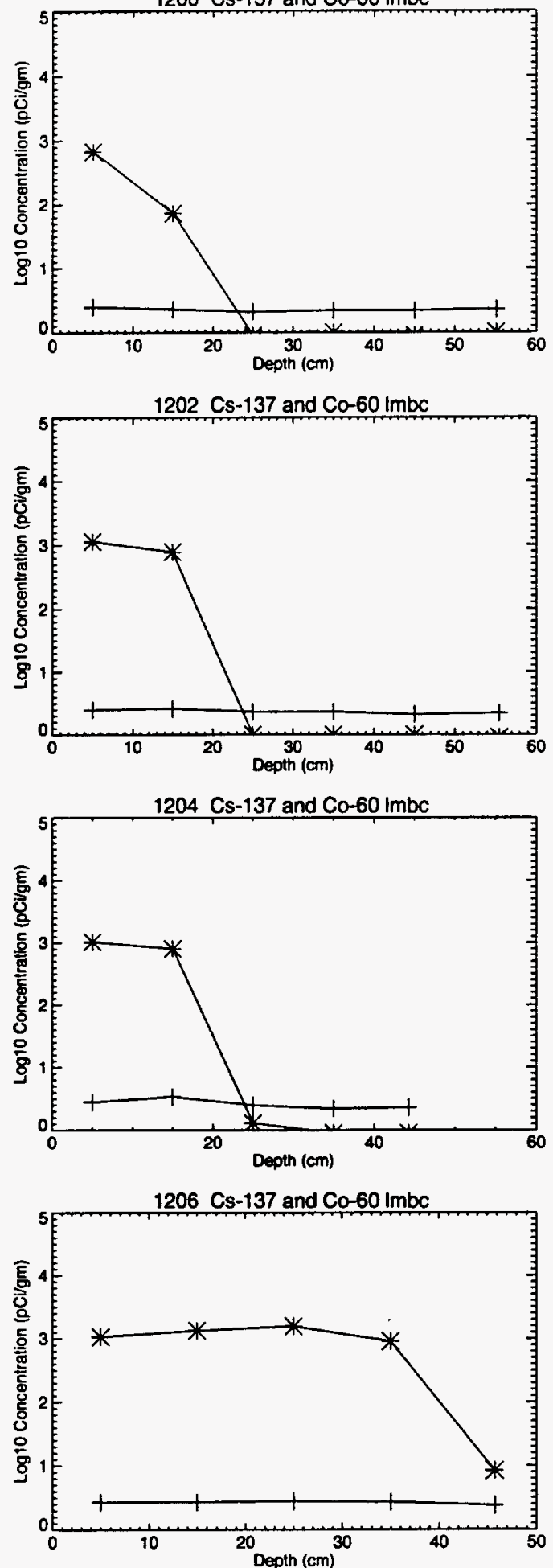

$1201 \mathrm{Cs}-137$ and Co-60 Imbc

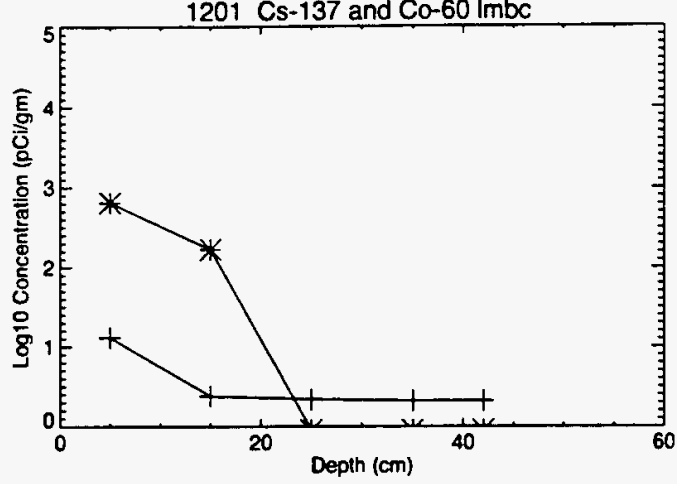

1203 Cs-137 and Co-60 Imbc
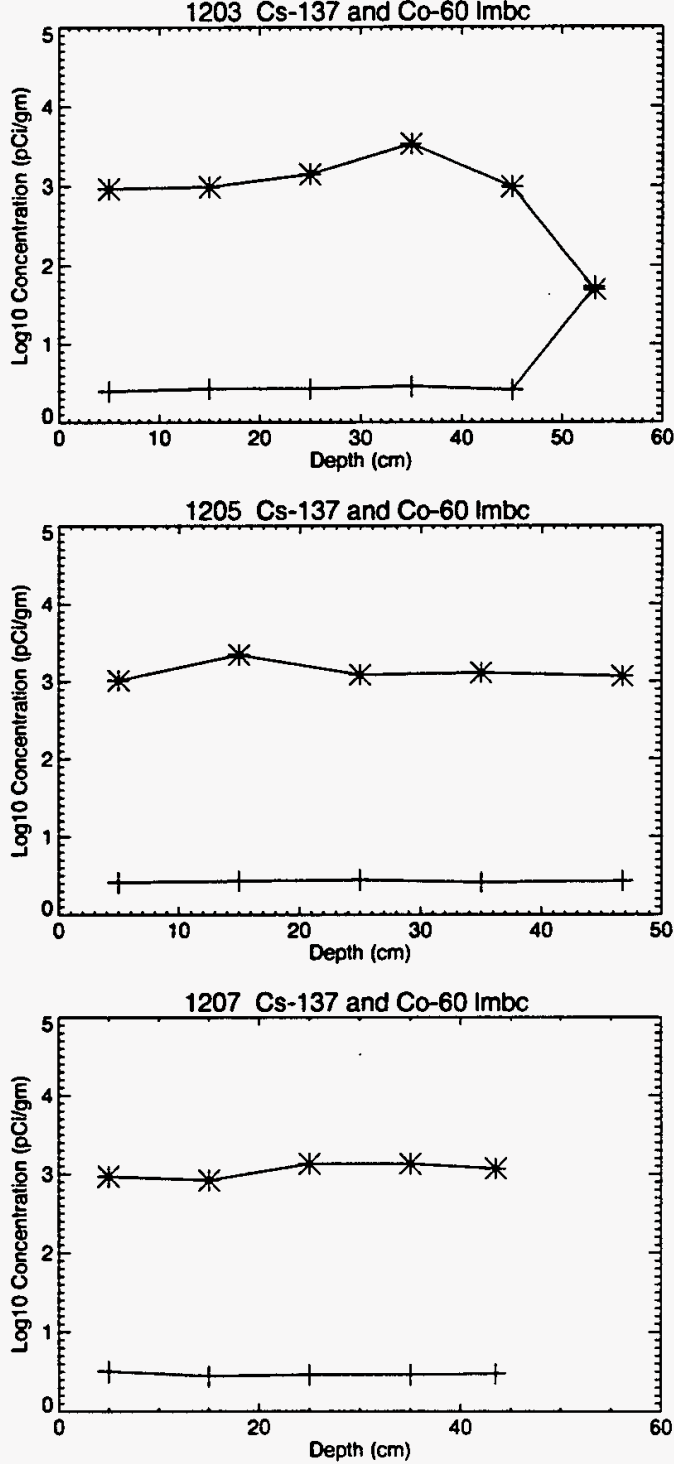

Fig. C.21. Plots of ${ }^{137} \mathrm{Cs}$ concentrations (asterisks) and ${ }^{60} \mathrm{Co}$ concentrations (stars) in sediment sampled during 1995 at sites $1200,1201,1202,1203,1204,1205,1206$, and 1207. 

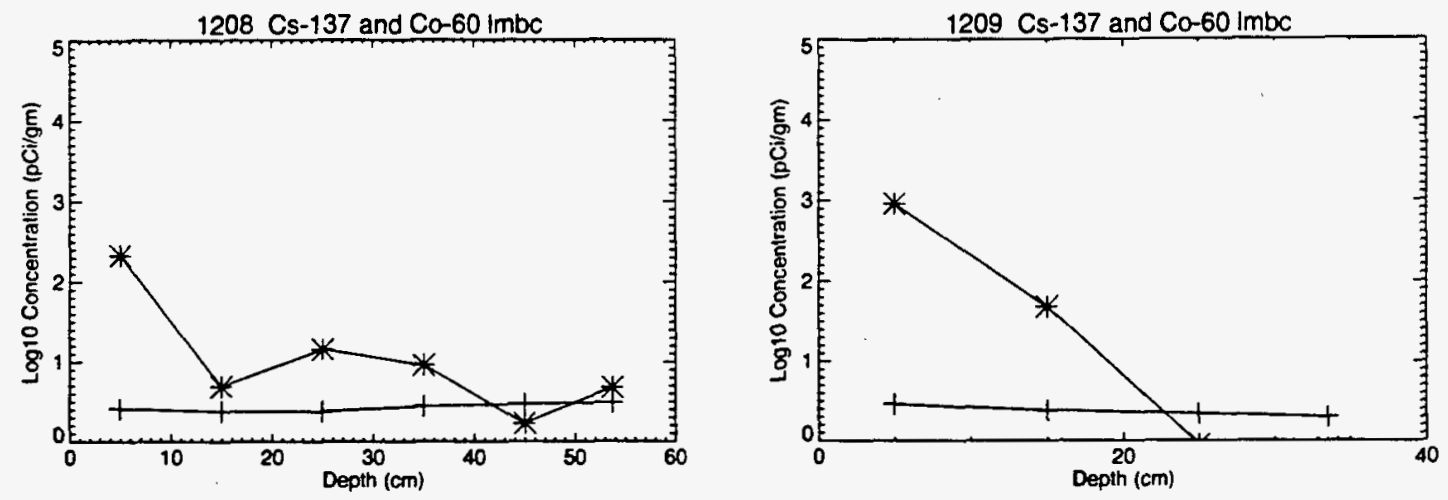

Fig. C.22. Plots of ${ }^{137} \mathrm{Cs}$ concentrations (asterisks) and ${ }^{60} \mathrm{Co}$ concentrations (stars) in sediment sampled during 1995 at sites 1208 and 1209. 


\section{INTERNAL DISTRIBUTION}

1.

B. B. Burgoa

2. R. B. Cook

3. J. H. Cushman

4. D. E. Fowler

5. S. G. Hildebrand

6. G. K. Jacobs

7. P. Kanciruk

8. R. H. Kettelle

9. J. M. Loar

10. G. M. Logsdon
11. D. E. Reichle

12. D. S. Shriner

13. D. S. Tharpe

14. Central Research Library

15-29. ESD Library

30-31. Laboratory Records Dept.

32. Laboratory Records, ORNL-RC

33. ORNL Patent Section

34. Y-12 Technical Library

\section{EXTERNAL DISTRIBUTION}

35. H. L. Boston, Lockheed Martin Corporation, Hanford, 2950 George Washington Way, Richland, WA 99352

36. M. Broido, Acting Director, Environmental Sciences Division, ER-74, Department of Energy, 19901 Germantown Road, Germantown, MD 20874

37. F. A. Donath, Director, Institute for Environmental Education, Geological Society of America, 1006 Las Posas, San Clemente, CA 92673

38. C. J. Ford, 111 Dayton Road, Oak Ridge, TN 37830

39. D. W. Freckman, Director, College of Natural Resources, 101 Natural Resources Building, Colorado State University, Fort Collins, CO 80523

40. R. O. Hultgren, ORNL Site Manager, Department of Energy, Oak Ridge National Laboratory, P. O. Box 2008, Oak Ridge, TN 37831-6269

41. A. Patrinos, Associate Director, Office of Health and Environmental Research, G-165, U.S. Department of Energy, Germantown, MD 20585

42. G. S. Sayler, Professor, 10515 Research Drive, Suite 100, The University of Tennessee, Knoxville, TN 37932-2567

43. Office of Assistant Manager for Energy Research and Development, U.S. Department of Energy Oak Ridge Operations, P.O. Box 2001, Oak Ridge, TN 37831-8600

44-45. Office of Scientific and Technical Information, P.O. Box 62, Oak Ridge, TN 37831 


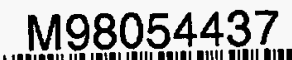

||||||||||||||||||||||||||||||||||||||||||||||||||||||||||||

Report Number (14)OKO/L/T/ - 13208

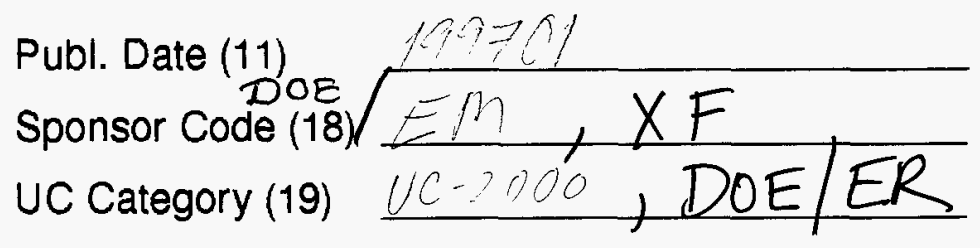

19980707095 